\title{
Western States Enhanced Oil Shale Recovery Program Shale Oil Production Facilities Conceptual Design Studies Report
}

\section{Topical Report}

August 1989

Work Performed Under Cooperative Agreement No.: DE-FC21-86MC11076

For

U.S. Department of Energy

Office of Fossil Energy

Morgantown Energy Technology Center

Morgantown, West Virginia

This document is PUBLICLY RELEASABR

By

Western Research Institute

Laramie, Wyoming
Authorizing Official

Dom:

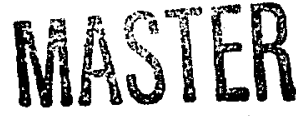

…… 


\section{DISCLAIMER}

This report was prepared as an account of work sponsored by an agency of the United States Government. Neither the United States Government nor any agency Thereof, nor any of their employees, makes any warranty, express or implied, or assumes any legal liability or responsibility for the accuracy, completeness, or usefulness of any information, apparatus, product, or process disclosed, or represents that its use would not infringe privately owned rights. Reference herein to any specific commercial product, process, or service by trade name, trademark, manufacturer, or otherwise does not necessarily constitute or imply its endorsement, recommendation, or favoring by the United States Government or any agency thereof. The views and opinions of authors expressed herein do not necessarily state or reflect those of the United States Government or any agency thereof. 


\section{DISCLAIMER}

Portions of this document may be illegible in electronic image products. Images are produced from the best available original document. 


\section{DISCLAIMER}

This report was prepared as an account of work sponsored by an agency of the United States Government. Neither the United States Government nor any agency thereof, nor any of their employees makes any warranty, express of implied, or assumes any legal liability or responsibility for the accuracy, completeness or usefulness of any information, apparatus, product, or process disclosed, or represents that its use would not infringe privately owned rights. Reference herein to any specific commercial product, process, or service by trade name, trademark, manufacturer, or otherwise, does not necessarily constitute or imply its endorsement, recommendation, or favoring by the United States Government or any agency thereof. The views and opinions of authors expressed herein do not necessarily state or reflect those of the United States Government or any agency thereof.

This report has been reproduced directly from the best available copy.

Available to DOE and DOE contractors from the Office of Scientific and Technical Information, P.O. Box 62, Oak Ridge, TN 37831; prices available from (615)576-8401, FTS 626-8401.

Available to the public from the National Technical Information Service, U.S. Department of Commerce, 5285 Port Royal Rd., Springfield, VA 22161.

Price: Printed copy A10 Microfiche AO1

Codes are used for pricing all publications. The code is determined by the number of pages in the publication. Information pertaining to the pricing codes can be found in the current issues of the following publications, which are generally available in most libraries: Energy Research Abstracts (ERA), Government Reports Announcements and Index (GRA and I); Scientific and Technical Abstracts Reports (STAR); and publication NTIS-PR-360 available from NTIS at the above address. 


\section{TABLE OF CONTENTS}

EXECUTIVE SUMMARY

Design Basis

Costs

Schedule

Economic Analysis

Project Description

Technical Feasibility

INTRODUCTION

DESIGN BASIS

Case 1 - Commercial Plant

Cases 2 and 2A - Demonstration Plant

Case 3 - Pilot Plant

COSTS

Capital Costs

Operating Costs

Unallocated Support Costs

Products and By-Product

SCHEDULE

Case 1 - Commercial Plant

Cases 2 and $2 \mathrm{~A}$. Demonstration Plant

Case 3 - Pilot Plant

Pre-Commercialization Plan

ECONOMIC ANALYSIS

Summary

Financial Analyses

Economic Evaluation Assumptions

PROJECT DESCRIPTION

Site Description

Mine Plan

General Process Facility Description

Utility Requirements

Catalyst and Chemical Consumption 


\section{TECHNICAL FEASIBILITY}

Modified-In-Situ Retort

MIS Off-gas Processing

Above Ground Retorting

Circulating Fluidized Bed Combuster

Oil Upgrading Facility 
1-1 Shale Oil Production

1-2 Design Criteria for Study Cases 1 through 3

1-3 Annual Operating Costs

1-4 Capital Costs Summary

1-5 Cash Flow Projections - Case 1 - 0\% Real Growth

1.6 Cash Flow Projections - Case 1 - $2 \%$ Real Growth

1-7 Overall Material Balance - Case 1

1-8 Overall Material Balance - Case 2 and 2A

3-1 Design Criteria for Study Cases 1 through 3

4-1 Capital Cost Summary - Case 1

4-2 Annual Operating Cost

4-3 Estimated Manpower Requirements

4-4 Unallocated Support Costs

4-5 Products and By-Product

6-1 Cash Flow Projections - Case 1 -0\% Real Growth

6-2 Cash Flow Projections - Case 1 : $2 \%$ Real Growth

6-3 Cash Flow Projections - Case 2

6-4 Cash Flow Projections - Case 2A

6-5 Cash Flow Projections - Case 3

7-1 Overall Material Balance - Case 1

7-2 Overall Material Balance - Case 2 and 2A

7-3 Overall Material Balance - Case 3

7-4 Molar Ratio of Ca to S - Case 1

7-5 Molar Ratio of $\mathrm{Ca}$ to $\mathrm{S}$ - Case 2

7-6 CFBC - Material/Utility Balance - Case 1

7-7 CFBC - Material/Utility Balance - Case 2

7-8 CFBC - Material/Utility Balance - Case 2A

7-9 HRS Above Ground Retort Facilities

Material Balance - Case 1

7-10 HRS Above Ground Retort Facilities

Material Balance - Case 2 and 2A

7-11 HRS Above Ground Retort Facilities

Material Balance - Case 3

7-12 Utility Requirements - Case 1

7-13 Utility Requirements - Cases 2 and $2 \mathrm{~A}$

7-14 Utility Requirements - Case 3

7-15 Catalyst and Chemical Consumption - Case 1

7-16 Catalyst and Chemical Consumption - Cases 2 and 2A 


\section{LIST OF FIGURES}

Figure

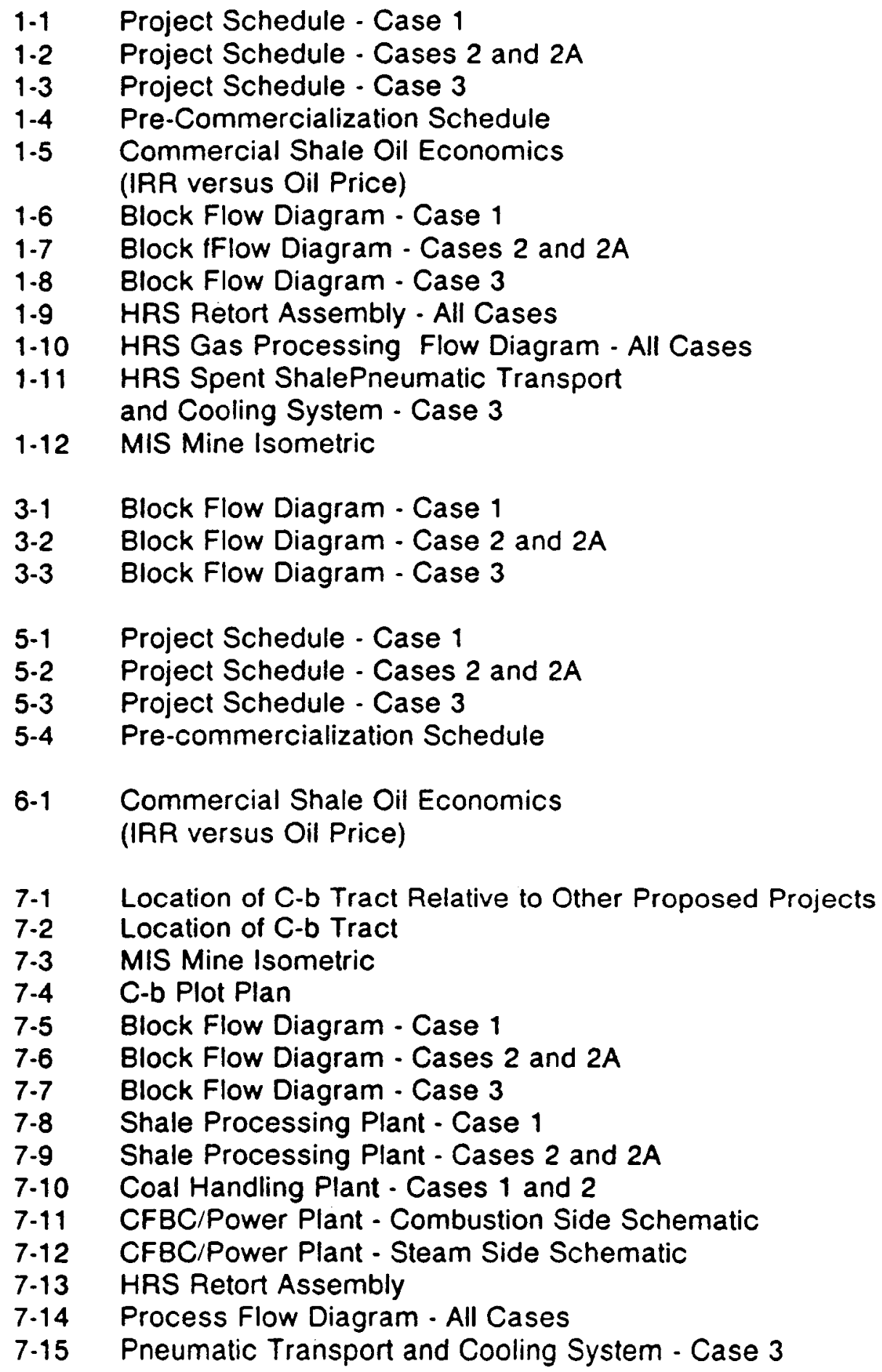




$\begin{array}{ll}\text { AGR } & \text { Above Ground Retort } \\ \text { BbI } & \text { Barrel } \\ \text { BPCD } & \text { Barrels per Calendar Day } \\ \text { BPSD } & \text { Barrels per Stream Day } \\ \text { BTU } & \text { British Thermal Unit } \\ \text { CD } & \text { Calendar Day } \\ \text { CFBC } & \text { Circulating Fluidized Bed Combustor } \\ \text { C-b } & \text { Cathedral Bluffs } \\ \text { EOR } & \text { Enhanced Oil Recovery } \\ \text { GPM } & \text { Gallons per Minute } \\ \text { GPT } & \text { Gallons per Ton } \\ \text { H2S } & \text { Hydrogen Sulfide } \\ \text { HIGG } & \text { Hot Inert Gas Generator } \\ \text { HRS } & \text { Hot Recycled Solids } \\ \text { IRR } & \text { Internal Rate of Return } \\ \text { Kwh } & \text { Kilowatt-hour } \\ \text { IbS/hr } & \text { Pounds per Hour } \\ \text { LLNL } & \text { Lawrence Livermore National Laboratory } \\ \text { L.O. } & \text { Light Oil } \\ \text { MIS } & \text { Modified-in-Situ } \\ \text { MM } & \text { Million . } \\ \text { MW } & \text { Megawatts } \\ \text { NOx } & \text { Nitrous Oxides } \\ \text { NPV } & \text { Net Present Value } \\ \text { OUG } & \text { Oil Upgrading } \\ \text { PSA } & \text { Pressure Swing Absorption } \\ \text { PURPA } & \text { Public Utilities Regulatory Policy Act } \\ \text { S } & \text { Sulfur } \\ \text { SCF } & \text { Standard Cubic Feet } \\ \text { SCFD } & \text { Standard Cubic Feet per Day } \\ \text { SCOT } & \text { Shell Claus Off-gas Treating } \\ \text { SD } & \text { Stream Day } \\ \text { SFC } & \text { Synthetic Fuels Corporation } \\ \text { SO } 2 & \text { Sulfur Dioxide } \\ \text { SOX } & \text { Sulfur Oxides } \\ \text { SPF } & \text { Surface Processing Facilities } \\ \text { ST } & \text { Short Ton (2000 pounds) } \\ \text { STPY } & \text { Short Tons per Year } \\ \text { TPCD } & \text { Tons per Calendar Day } \\ \text { TPSD } & \text { Tons per Stream Day } \\ \text { TPSH } & \text { Tons per Stream Hour } \\ \text { URS } & \text { Underground Retorting System } \\ & \end{array}$


This report analyzes the economics of producing syncrude from oil shale combining underground and surface processing using Occidental's Modified-In-Situ (MIS) technology and Lawrence Livermore National Laboratory's (LLNL) Hot Recycled Solids (HRS) retort. These retorts form the basic technology employed for oil extraction from oil shale in this study. Results are presented for both Commercial and Pre-commercial programs.

For a Commercial plant at the Cathedral Bluffs (C-b) site, with an investment of 1.2 billion dollars, in Rio Blanco County, Colorado. the economic analyses indicate that a twenty percent $(20 \%)$ return on equity will require a syncrude price of $\$ 23.35$ dollars per barrel. This price assumes a $2 \%$ real growth (above inflation) in the price of oil.

Also analyzed in the report are the Pre-commercialization cost of Demonstration and Pilot programs which will confirm the HRS and MIS concepts and their mechanical designs. These programs will provide experience with the Circulating Fluidized Bed Combustor (CFBC), the MIS retort, the HRS retort and establish environmental control parameters. A Pre-commercialization study at $\mathrm{C}-\mathrm{b}$ will require a total after tax expenditure of $\$ 213.4$ million dollars over a period of 10 years.

Four cases are considered to develop the Commercial and Precommercialization programs. This study determines budget cost estimates and schedules for each of the cases. The process flow schemes and basic heat and material balances are determined for the HRS system. The results of this study consist of summaries of major equipment sizes, capital cost estimates, operating cost estimates and economic analyses.

The four cases are:

Case 1 - Commercial Size Plant

Case 2 - Demonstration Size Plant

Case 2A- Demonstration Size Plant - minimum size CFBC

Case 3 - Pilot Size Plant

Case 2, 2A and 3 are combined for the Pre-commercialization program. This program integrates the schedules for the 
Demonstration and Pilot size plants. The pro-forma cash flow for an integrated Pre-commercialization program is analyzed.

Individual cases are more fully described below:

Case 1 is the Commercial size facility which produces 24,344 BPSD of syncrude. The facility includes mining facilities, MIS processing, materials handling, HRS above ground retorting (AGR), Circulating Fluidized Bed Combustor, Oil Upgrading and a syncrude pipeline. This plant is sized with 22 simultaneously operating MIS retorts, five CFBC's and one HRS above ground retort. The HRS above ground retort facility is designed for a throughput of 12,850 tons of raw shale per day which comes from the void space produced in the retorts before rubblization. The net electric power production is 39 megawatts.

Case 2 is the Demonstration size plant which produces 1884 BPSD of shale oil. The plant includes: MIS miring, MIS processing, materials handling, HRS above ground retorting and the CFBC. Two simultaneously operating MIS retorts, one CFBC and one AGR are in operation for this plant. The CFBC is sized to be one of the five required for the Commercial plant. This CFBC is larger than required for processing the MIS off-gas and supplemental fuel (coal) will be required to operate at capacity. The supplemental fuel will require additional material handling but will also produce extra power for sale. The CFBC can later serve as one of the units needed in the Commercial size plant. The raw shale feed to the HRS above ground retort will be 1,000 tons/day. This case will produce 25 megawatts of power. The use of coal may qualify the plant for benefits under the government's Clean Coal Technology program.

Case $2 \mathrm{~A}$ is also a Demonstration size plant. The difference between this case and Case 2 is the size of the CFBC. The CFBC is sized to optimally handle the effluents from the above and below ground retorts with a minimum of supplemental fuel. This reduced size CFBC will reduce the capital investment for the Demonstration plant. The power available for sale is 4 megawatts.

Case 3 is the Pilot size plant. The objective of this size plant is to establish the process design and operating conditions for the HRS retort. The raw shale feed is 100 tons/day of raw shale. The only facilities involved are the materials handling and the Above Ground Retorting system. There will not be any mining involved as the shale is already stockpiled ready for crushing and feeding into the retort. The pilot plant produces 62 BPSD of shale oil. 
In addition to the above descriptions, other equipment requirements include storage and truck loading facilities for product oil from the Pilot and Demonstration size plants. Hauling of spent shale from the CFBC is provided, as is a flare system in the pilot facility for the incineration of process off-gas.

The shale oil products produced in each of the cases are summarized in Table 1-1.

Federal lease C-b comprises a 5,094 acre tract of land in Rio Blanco County in Colorado. This tract is leased from the U. S. Department of Interior by Occidental Oil Shale, Inc. The current mine shafts give access to recoverable reserves of 1.8 billion barrels of shale oil.

The design basis was derived from engineering studies and process designs carried out by Bechtel and other contractors. The mining cost estimates, provided by Agapito and Associates, are located in the appendix.

\section{DESIGN BASIS}

The design bases for all cases are summarized in Table 1-2.

Case 1 is the Commercial size plant with 22 MIS retorts burning simultaneously, one AGR and five CFBC's. The overall oil production from MIS and HRS retorts amounts to 24,344 BPSD, after upgrading. The Above Ground Retort throughput is 12,850 tons/day of mined raw shale.

Case 2 and 2A, the Demonstration size plant, will consists of two MIS retorts with a HRS retort to give a total raw shaleoil production rate of 1884 BPSD. Mined raw shale processing in the Above Ground Retort is 1,000 tons/day.

Case 3, the Pilot size plant will produce 62 BPSD of raw shale oil. No MIS retorts are used in this case. This plant will process 100 tons/day of stockpiled raw shale. 
The capital and operating cost for the four cases are summarized in Tables 1-3 and 1.4, respectively. The total capital cost and operating cost for these cases are as follows:

Capital Costs

(\$ millions)

Case 1

Case 2

Case 2A

Case 3
$1,162.9$

243.5

230.8

19.5
Operating Costs

(\$ million/year)

178.0

34.6

30.3

$5.0^{*}$

* Based on one year of operation

The following items are not included in these capital costs:

- Sunk cost already expended in the development at the C-b site

- Costs associated with working capital and financing

- Income taxes

\section{SCHEDULE}

The overall schedules for Cases $1,2 / 2 A$, and 3 are shown in Figures 1-1 through 1-3. The time required from kickoff until the completion of Commissioning and Start-up is summarized below.

$\begin{array}{lll}\text { Case 1 } & \text { Commercial Plant } & 6 \text { years } \\ \text { Case 2, 2A } & \text { Demonstration Plant } & 4 \text { years } \\ \text { Case 3 } & \text { Pilot Plant } & 3 \text { years }\end{array}$

If process development on the three cases is done sequentially, the overall schedule would be approximately 15 years. This allows for the Pilot and Demonstration plants to be in operation one year each before design of the next size facility.

The Pre-commercialization plan, which integrates the schedules of the Pilot and Demonstration Plant, and takes into account the advanced readiness of the MIS retort, will take a total of 10 years. The project schedule for this pre-commercialization plan is shown 
in Figure 1-4. This integrated schedule would allow for a faster start-up of the MIS Commercial size plant and accomodate the longer development schedule for the HRS process.

\section{ECONOMIC ANALYSIS}

An economic analysis is presented which determines the oil price required to generate return on equity for Case 1 , the Commercial size plant. Cases 2 and 3 are combined into the integrated Precommercialization plan and 10 year cash expenditures are computed.

The results of the economic analysis for the commercial case are summarized in Figure 1-5. The curves show the oil prices required to obtain returns on equity varying from 5 to 25 percent. The curves assume a financing structure of $75 \%$ debt and $25 \%$ equity with a ten percent $(10 \%)$ interest on debt. The income tax rate was calculated at 37.3 percent. The curves are developed based on oil prices keeping pace with inflation and inflation plus $2 \%$ per year real growth. The inflation rate used in these calculations is 5 percent per year. The required shale oil prices for the Commercial size plant are shown below.

Required Shale Oil Price vs Return On Equity, (\$/BBI)

$\begin{array}{crr}\text { Return on Equity } & \mathbf{0} \% \text { growth } & \mathbf{2} \% \text { growth } \\ 5 & & \\ 10 & 25.58 & 17.80 \\ 15 & 26.70 & 19.57 \\ 20 & 27.90 & 21.40 \\ 25 & 29.35 & 23.35 \\ & 31.05 & 25.40\end{array}$

(adjusted for an inflation rate of $5 \%$ /year)

The detailed cash flow analyses are shown on Tables 1-5 and 1-6.

For the demonstration, pilot, and integrated Pre-commercialization facilities, the cumulative after tax cash flows are as follows:

Cumulative After Tax Cash Flows, SMM

$\begin{array}{lll}\text { Case 2 } & - & 206.6 \\ \text { Case 2A } & - & 227.7 \\ \text { Case 3 } & - & 18.0\end{array}$


Pre-commercialization Plan

The integrated Pre-commercialization plan can be built and operated for $\$ 213.4 \mathrm{MM}$ depending on future financial conditions and assumptions for revenues generated from oil and power sales. The program will perfect MIS mining and oil shale processing technologies and provide experience needed for scale up and process integration.

The cash requirements for the Pre-commercialization plan can be reduced by allowing outside participation in certain sections of the facility. For example, an electric utility may be interested in owning the CFBC and power generation sections. By allowing outside participation, the annual cash flow requirements and long term benefits can be spread among project participants.

\section{PROJECT DESCRIPTION}

The processing facilities for Case 1 are shown in Figure 1-6, with the material balance shown in Table 1-7. The Demonstration facilities for Cases 2 and $2 A$ are shown in Figure 1-7, with the material balance shown in Table 1-8.

The Pilot plant consists only of the HRS above ground retort and associated equipment. It does not incorporate the MIS retort or off-gas processing units. It will be used to test the spent shale cooling and moisturizing process. A block flow diagram for this case appears as Figure 1-8.

The processing facilities are shown in Figures 1-9, 1-10 and 1-11.

\section{Modified-In-Situ Development Mining}

MIS Mining. Mining for retort development will occur on three mining levels: upper void, intermediate void and lower void levels. Clusters of retorts will be accessed through a double entry drift system on each level using an advance mining system. system of ore passes and ventilation raises will provide ventilation and provide for transfer of mined shale to the loadout bins. Warehouses and shops are located on the mining levels. An isometric sketch of the mine retorts is shown in Figure 1-12.

The underground retort is a rectangular column of shale which is prepared by mining out a total of $23 \%$ of the retort volume from the appropriate levels. 
MIS Rubblization and Construction. After the retort is mined, the retort must be fragmented to a uniform particle size. Vertical blastholes are drilled into the retort block from the upper and intermediate levels. Horizontal blastholes are drilled into the support pillars on each level.

The blastholes are loaded with explosives and rubblized with one sequential blast. After rubblization, retort bulkheads are constructed in the retort access drifts. All process piping and instrumentation for retort opperations are connected to and through the bulkheads.

For the commercial mine, 28 retorts per year will be mined out and developed. This requires completion of the existing loadout bins at the bottom of the mine shaft and the construction of a large live storage bin underground, connecting shafts and a materials handling conveyor system.

For the development mine, 17 retorts will be developed during a 5 to 6 year mining program. The shale handling facilities which presently exist with some modifications and completion will be able to handle the mined shale.

\section{Modified-In-Situ Processing Facilities}

MIS processing facilities consist of two subsets: Underground Retorting system and Surface Processing Facilities system. The Underground Retorting system consists of MIS retorts, off-gas drifts (or piping in the Demonstration case), raises common to all retorts, and piping and control units which connect individual retorts to the common off-gas drifts. Low BTU gas is transported to the surface through common off-gas drifts and raises. Off-gas collected from the In-situ operation is combined with off-gas from the active AGR retort and then fed to the CFBC.

Surface processing facilities consist of off-gas processing, off-gas compression and foul water stripping. The off-gas is a low-BTU fuel gas saturated with water and contains condensable hydrocarbons, ammonia and sulfur bearing constituents. Condensable hydrocarbons are recovered by processing the offgas through water contact condensers and sponge oil scrubbers. Cooling also condenses water which is stripped of ammonia and sulfur bearing constituents. The water is then used in the deashing process. The ammonia and sulfur bearing constituents are incinerated in the CFBC. 


\section{Material Handling Facilities}

The materials handling facilities contain equipment for receiving and stockpiling crushed shale from the mine and for providing surge storage between the mine and surface facilities. The shale is crushed and screened to $1 / 4$ inch. The shale feed to the above ground HRS Pilot plant retort will be taken from a stockpile, crushed and screened.

\section{Above Ground Retorting Facilities}

The Above Ground Retort employs an innovative concept developed by Lawrence Livermore National Laboratory (LLNL) which uses a recirculating hot-solid heat carrier to accomplish pyrolysis.

This hot-recycled-solids (HRS) retort consists of a Pyrolyzer (retort) through which raw shale and hot-recycled-solids pass in plug flow by gravity. Oil vapor and gas derived in the pyrolyzer pass radially across the pyrolyzer and are collected and removed at several points. The retorted shale is conveyed pneumatically through an Air Lift combustor to a Classifier where the hot solids disengage from the flue gas. The hot solids fall from the Classifier through a Delayed Fall Combustor followed by a Fluidized Bed Combustor (FBC) where essentially all combustibles remaining on the recycled solids are burned. Removal of retorted shale from the FBC is regulated to maintain a level in the FBC. The hot recycled solids are combined with raw shale in a Fluid Bed Mixer before entering the Pyrolyzer.

The hot-recycled-solids retort concept has several advantages over gas heated retort concepts.

- Gas compression costs are significantly lower.

- Rapid shale throughput is possible (reducing product degradation due to cracking and less shale residence time).

- Fine shale particles can be processed and need not be discarded or combusted.

- Minimal gas cleanup is required over processes which use air. (hot gas is not diluted with nitrogen). 
Major pieces of equipment are shown in Figure 1-9.

The oil vapor quench system consists of two (2) quench towers and associated equipment as shown in Figure 1-10. The deashing system consists of mixing the oil with hot water and electrostatically separating the oil and water phases. (The latter containing the ash.)

\section{Oil Upgrading Facilities}

The oil upgrading facilities provided in the commercial plant, consist of five major units: fractionation, hydrotreating, hydrogen production, sour water treating, and sulfur recovery. The hydrotreating unit treats the raw shale oil with hydrogen over a proprietory catalyst to remove the nitrogen, oxygen and sulfur. This process produces a high quality syncrude which will exceed specifications for pipelining and conventional refinery feed. The hydrotreating and hydrogen units are sized to accommodate oil production from both the MIS and AGR retorts.

The hydrogen unit is a conventional reformer which utilizes natural gas for feed and a Pressure Swing Absorption (PSA) section to maintain high hydrogen purity. Wash water used for control of salt formation in the hydrotreating unit exchangers is stripped of H2S and ammonia before recirculation to the hydrotreating unit.

Hydrogen sulfide produced by hydrogenation is converted to elemental sulfur in a conventional Claus unit with a SCOT tail gas unit provided to reduce the sulfur emissions to prescribed limits.

Ammonia is recovered by means of a proprietary process, Phosam-W.

\section{Circulating Fluidized Bed Combustor Power Generation}

Low-BTU off-gas from MIS and off-gas streams from other units are fed to the CFBC along with spent shale from the HRS retort. Superheated steam at 1,325 psia and $955^{\circ} \mathrm{F}$ is generated in the CFBC for the Commercial size plant. Steam at the same conditions is generated in the Demonstration size plant. The superheated steam is fed to a steam turbine generator to produce power and to extract steam at various pressures required within the facilities. Virgin oil shale and/or retorted shale, which contains considerable calcium and alkali minerals, capture $\mathrm{SO}_{2}$ from the feed materials. Coal is provided as a supplemental fuel for CFBC flame stability. 
Product Oil Transport Facilities

Syncrude produced in the Commercial size plant (Case 1) is shipped to an existing crude oil pipeline at Rangely, Colorado by means of a syncrude pipeline. For the Pre-commercialization facilities, the product shale oil will be transported by truck.

\section{TECHNICAL FEASIBILITY}

Technical feasibility assessments have been carried out on the following major process units:

- MIS Technology

- Above Ground Retorts (AGR) facilities

- Oil Upgrading facilities (OUG)

- Circulating Fluidized Bed Combustor (CFBC)

\section{MIS Technology}

MIS retorts have been demonstrated since 1972. Commercial size retorts number 7 and 8 located at Logan Wash produced extensive data for the design basis.

Processing the MIS off-gas utilizes conventional refinery type hydrocarbon processing technologies. These technologies have been used extensively in petroleum refining throughout the world.

\section{Above Ground Retort (AGR) Facility}

The HRS retort has been demonstrated on a laboratory scale by LLNL since 1984. Case 3, the Pilot plant, will be used to demonstrate the workability of the design and scale up from laboratory size. Research on a pre-pilot plant scale is also anticipated prior to completion of the design for the pilot plant.

\section{Oil Upgrading Facility (OUG)}

Upgrading of the shale oil from both the MIS and HRS retorts utilizes conventional technology. The processes employed have 
been demonstrated at commercial scale at the Unocal Parachute, Colorado plant. It has processed over one million Barrels of shale oil through the oil upgrading facility.

Sour water produced will be used in the deashing process and for moisturizing shale ash from the CFBC.

The deashing process is an electrostatic demineralization process used extensively in petroleum refining throughout the world.

\section{Circulating Fluidized Bed Combustor (CFBC)}

The CFBC has been used at a commercial size for coal processing with limestone as the SOx adsorbent. The licensor of the technology believes that after testing at pilot scale, the technology is ready for demonstration scale testing utilizing MIS gas and coal, with shale as an adsorbent. 


\section{Table 1-1}

\section{SHALE OIL PROOUCTION}

$$
\text { (BPSD) }
$$

MIS OIL

AGR OIL

TOTAL MIS PLUS AGR OIL

TOTAL OIL AFTER UPGRADING

\begin{tabular}{cccc}
\multicolumn{5}{c}{ CASE } \\
1 & 2 & $2 A$ & 3 \\
$\ldots \ldots \ldots$ & $\ldots \ldots$ & $\ldots \ldots$. & $\ldots \ldots$ \\
13,964 & 1,269 & 1,269 & $\ldots$. \\
7,930 & 695 & 615 & 62
\end{tabular}

$\begin{array}{llll}21,894 & 1,884 & 1,884 & 62\end{array}$

24,344

NOTE: Case 1 is the Commercial Plant

Case 2 is the Demonstration Plant

Case $2 A$ is the Demonstration Plant with minimum size CFBC

Case 3 is the Pilot Plant 
Table 1-2

\section{Design Criteria}

\section{Basis}

Site

Location

Mining Facilities

Mine lype

Classification

Mining Method

Oil shale Grade

Productions Days

Annual Production

\section{MIS Retort Development Mining}

\section{Facilities}

Mining Method

Oil Shale Grade

- mined to AGR/CFBC

- rubblized-in-place

Production Days

Annual Production

\section{Material Handling Facilities}

Local Coarse Shale Stockpile

Remote Coarse Shale Stockpile

Retort Feed Storage

Aboveground Retort Facilities (AGR)

Retort Technology

Retort Feed

Feed Shale Grade

Steady State Stream Factor

No. of Retorts

\section{Case 1}

Commercial

C-b tract

Rio Blanco County

Shaft Mine

Gassy-Nonmetal

-

-

0

\section{Case 2/2A}

Demonstration

C-b tract

Rio Blanco County

\section{Shaft Mine}

Gassy-Nonmetal

-

0

Rm. \& Pillar (ea. void level)

\section{GPT Average \\ 27 GPT Average \\ 357 Days per Year \\ 4,700,000 Tons}

37,000 T Live, 13,500 T Dead

3.6 Million Tons

7,000 Tons (13 hours)

LLNL HRS
12,800 TPSD
Gallons per Ton
$95 \%$
1

$$
\begin{gathered}
27 \text { GPT Average } \\
27 \text { GPT Average } \\
357 \text { Days per Year } \\
420,000 \text { Tons }
\end{gathered}
$$

LLNL HAS

1000 TPSD

27 Gallons per Ton

$95 \%$

\section{Case 3}

Pilot

C-b Tract

Rio Blanco County

N/A

N/A

$4500 \mathrm{~T}$ Live, 13.500 T Dead

Coarse shale stockpile from mine

development

LLNL HRS
100 TPSD

27 Gallons per Ton

$95 \%$ 
Table 1-2

\section{Design Criteria (Continued)}

Case 1

Case 2/2A

Case 3
Occidental MIS Technology

2 Retorts Burning Simultaneously

1 Retort Ignited Every 146 Days

2.5 Retorts Processed per Year

N/A

N/A

N/A

Drums

15 days storage for light and

$$
\text { bulkhead }
$$

Mine Inflow supplemented with wells Mine in llow supplemented with wells Minimal

Minimal

Power generated at site

Purchased

N/A

$3400 / 650$

$50 / 25$

366

840

$25 / 4$

$1790^{*}$

/A

$\sqrt{1}$

\section{Basis}

Modified in Situ Processing Facilities

Underground Retorting System

Retort Technology

Retort Processing Rate

Oil Upgrading Facilities

Hydrotreating Technology

Normal Feed Rate

Syncrude Production

Syncrude Pipeline Facilities

Capacity

Destination

Utilities and Offsite Facilities

Intermediate and Syncrude Tankage

Water Source

Overcapacity

Power Source

Coal

Foed to CFBC. TPD

Coal Stockpile.Tons

Feed Storage,Tons

Capacity of ProducuBy-Products

Light Oil, BPCD

Bulkhead Oil, BPCD

Power to Grid, MW

Treated Oil, BPCD
Sulfur Removal Technology
Occidental MIS Technology

22 Retorts Burning Simultaneously

1 Retort Ignited Every 14 Days

27.5 Relorts Processed per Year

Union Oif

21,894 BPSD (20,799 BPCD)

Claus Unit

8.4 Million Barrels per Year

23.000 BPCD

Chevron Rangely Terminal

7 days

Mine Inflow supplemented with wells Minimal

Power generated at site

1044
7000

250

$-$

39

23,126
* Raw untreatod shalo oil 
Table 1-3

CAPITAL COST SUMMARY

(s Millions)

\begin{tabular}{|c|c|c|c|c|c|}
\hline \multicolumn{6}{|l|}{ AREA/UNIT } \\
\hline NUABER & DESCRIPTION & CASE 1 & CASE 2 & CASE 2A & CASE 3 \\
\hline-- & MINE & 148.3 & 27.0 & 27.0 & 0.0 \\
\hline-- & MIS RETORT RUBBLIZATION \& CONSTRUCTION & 34.6 & 4.2 & 4.2 & 0.0 \\
\hline 3700 & UTILITIES & 16.8 & 5.2 & 5.2 & 0.0 \\
\hline 4000 & POWER DISTRIBUTION & 15.7 & 4.9 & 4.9 & 0.0 \\
\hline 4100 & INTERCONMECTING PIPEWAYS & 16.8 & 4.3 & 4.3 & 0.0 \\
\hline 4200 & BUILDINGS & 21.3 & 13.8 & 13.8 & 0.5 \\
\hline 4300 & SITE PREPARATION \& DEVELOPMENT & 16.8 & 5.8 & 5.8 & 0.2 \\
\hline 4400 & MOBILE EQUIPMENT & 6.7 & 2.9 & 2.9 & 0.1 \\
\hline 4500 & TANK FARM, YARD \& FLARE & 7.8 & 1.2 & 1.2 & 0.0 \\
\hline 4560 & SYMCRUDE PIPELINE & 11.2 & 0.0 & 0.0 & 0.0 \\
\hline $4611-14$ & HRS RETORT, QUENCH, DEASHING \& RECYCLE GAS & 31.5 & 11.6 & 11.6 & 9.2 \\
\hline 4615 & FRACTIONATION & 9.5 & 0.0 & 0.0 & 0.0 \\
\hline 4700 & SHALE PREPARATION \& HANDLING & 6.6 & 4.0 & 4.0 & 0.7 \\
\hline 4900 & CONTROL SYSTEMS & 4.4 & 1.1 & 1.1 & 0.0 \\
\hline 5000 & OIL UPGRADING FACILITIES & 121.0 & 0.0 & 0.0 & 0.0 \\
\hline 6000 & MIS PROCESS FACILITIES & 134.7 & 23.4 & 23.4 & 0.0 \\
\hline \multirow[t]{10}{*}{7000} & CFBC/PONER GENERATION & 162.5 & 52.3 & 43.6 & 0.0 \\
\hline & TOTAL DIRECT FIELD COST & 766.2 & 169.7 & 153.0 & 10.7 \\
\hline & INDIRECT FIELD COST & 188.7 & 39.8 & 37.7 & 2.6 \\
\hline & TOTAL FIELD COST & 954.9 & 201.5 & 190.7 & 13.3 \\
\hline & HOME OFFICE COST & 106.6 & 22.5 & 21.3 & 1.5 \\
\hline & TOTAL FIELD AND HOME OFFICE COST & 1061.5 & 224.0 & 212.0 & 14.8 \\
\hline & SPARE PARTS & 7.1 & 1.5 & 1.4 & 0.1 \\
\hline & STATE \& LOCAL TAXES & 25.4 & 5.4 & 5.1 & 0.3 \\
\hline & UNALLOCATED COST AND ROYALTIES & 68.8 & 12.6 & 12.4 & 4.3 \\
\hline & TOTAL PROJECT COST & 1162.8 & 243.5 & 230.9 & 19.5 \\
\hline
\end{tabular}

The sunk capital costs expended to-date are not included in the
capital costs listed above. 
Table $9-4$

\begin{tabular}{|c|c|c|c|c|c|c|c|c|c|}
\hline \multicolumn{10}{|c|}{$\begin{array}{l}\text { ANNUAL OPERATING COSTS } \\
\text { ( } \$ \text { thousands/year) }\end{array}$} \\
\hline & & \multicolumn{2}{|c|}{ Case 1} & \multicolumn{2}{|c|}{ Case 2} & \multicolumn{2}{|c|}{ Case 2A } & \multicolumn{2}{|c|}{ Case 3} \\
\hline & & Usage & Cost & Usage & $\operatorname{Cos} t$ & Usage & $\operatorname{Cos} t$ & Usage & $\cos t$ \\
\hline Natural Gas & $\$ 2.00$ /MMBTU & 702 & 12,299 & 11 & 193 & 11 & 193 & 1 & 18 \\
\hline Coal & $\$ 1.25$ /MMBTU & 896 & 9,811 & 433 & 4,741 & 82 & 892 & 0 & $9(3)$ \\
\hline Electricity & $\$ 0.05 / \mathrm{kwh}$ & 0 & 0 & 0 & 0 & & 0 & 171 & 75 \\
\hline Diesel Fuel & $\$ 1.25$ /gallon & & 1.115 & & 85 & & 85 & & 5 \\
\hline Raw Water & $\$ 250 / a c-f t$ & 3055 & 361 & 145 & 0 & 145 & 0 & 61 & $30(4)$ \\
\hline Catalysts an & micals & & 7,600 & & 29 & & 29 & & 0 \\
\hline Operating La & & 343 & 13,720 & 150 & 6,000 & 150 & 6,000 & 92 & $2,208(5)$ \\
\hline Maintenance & ial \& Labor & & 20,515 & & 4,330 & & 4,097 & & 286 \\
\hline Spent shale & sal & & 300 & & 27 & & 27 & & 24 \\
\hline Retort Rubbl & on \& Construction & & 44,324 & & $4,708(2)$ & & 4,708 & & 0 \\
\hline Mining & & & 42,942 & & $5,920(2)$ & & $5,920 \quad($ & & 0 \\
\hline Unallocated & & & $\begin{array}{c}25,051 \\
178,039\end{array}$ & & $\begin{array}{l}8,541 \\
34,574\end{array}$ & & $\begin{array}{l}8,314 \\
30,265\end{array}$ & & $\begin{array}{c}2,305 \\
4,960\end{array}$ \\
\hline
\end{tabular}

Hotes:

1. Does not include income taxes or Federal lease royalties.

2. First year of operation costs. Retort rubblization complete in two years of operation and retort construction in four years. Mining costs decrease for next two years as mining of retorts is completed.

3. Cost to dig and crush shale for feedstock.

4. Costs for raw water and for a steam boiler and water treating.

5. Cost for contract operators and maintenance for $1 / 2$ year. 
Table 1.5

CASH FLON PROJECTIONS - OX REAL GRONTH

(s millions as spent

\begin{tabular}{|c|c|c|c|c|c|c|c|c|c|c|c|}
\hline $\begin{array}{l}\text { YEAR } \\
\text { PROOUCTION ANO PRICES: } \\
\text { OIL PROOUCTION, MMBQL/YR } \\
\text { ANHUAL OIL PRICE }\end{array}$ & 29.35 & $\begin{array}{r}0 \\
30.82\end{array}$ & 32.36 & $\begin{array}{r}3 \\
0.4220494 \\
33.98\end{array}$ & $\begin{array}{r}4.220495 \\
35.68\end{array}$ & $\begin{array}{r}5 \\
7.174841 \\
37.46\end{array}$ & $\begin{array}{r}6 \\
8.44099 \\
39.33\end{array}$ & $\begin{array}{r}7 \\
8.44099 \\
41.30\end{array}$ & $\begin{array}{r}8 \\
8.44099 \\
43.36\end{array}$ & $\begin{array}{r}9 \\
8.44099 \\
45.53\end{array}$ & $\begin{array}{r}10 \\
8.44099 \\
47.81\end{array}$ \\
\hline $\begin{array}{l}\text { CASH FLON; } \\
\text { OIL REVENUES } \\
\text { BY-PROOUCT CREDITS } \\
\text { REVENUES }\end{array}$ & $\begin{array}{l}0.0 \\
0.0 \\
0.0\end{array}$ & $\begin{array}{l}0.0 \\
0.0 \\
0.0\end{array}$ & $\begin{array}{l}0.0 \\
0.0 \\
0.0\end{array}$ & $\begin{array}{r}14.3 \\
0.0 \\
14.3\end{array}$ & $\begin{array}{r}150.6 \\
10.5 \\
161.1\end{array}$ & $\begin{array}{r}268.8 \\
20.7 \\
289.4\end{array}$ & $\begin{array}{r}332.0 \\
29.0 \\
360.9\end{array}$ & $\begin{array}{r}348.6 \\
30.4 \\
379.0\end{array}$ & $\begin{array}{r}366.0 \\
31.9 \\
397.9\end{array}$ & $\begin{array}{r}384.3 \\
33.5 \\
417.8\end{array}$ & $\begin{array}{r}403.5 \\
35.2 \\
438.7\end{array}$ \\
\hline $\begin{array}{l}\text { O AND M COSTS } \\
\text { INTEREST EXPENSE }\end{array}$ & 0.0 & 0.0 & 0.0 & 4.1 & 50.4 & $\begin{array}{r}221.9 \\
7.0\end{array}$ & $\begin{array}{l}249.0 \\
128.1\end{array}$ & $\begin{array}{l}263.0 \\
128.1\end{array}$ & $\begin{array}{l}346.9 \\
128.1\end{array}$ & $\begin{array}{l}289.8 \\
128.1\end{array}$ & $\begin{array}{l}304.2 \\
128.1\end{array}$ \\
\hline NET OPERATING INCOME & 0.0 & 0.0 & 0.0 & 10.3 & 110.6 & 60.6 & -16.2 & -12.1 & -77.0 & -0.1 & 6.4 \\
\hline $\begin{array}{l}\text { TAX DEPRECIATION } \\
\text { OEPLETION }\end{array}$ & $\begin{array}{l}0.0 \\
0.0\end{array}$ & $\begin{array}{r}10.9 \\
0.0\end{array}$ & $\begin{array}{r}47.4 \\
0.0\end{array}$ & $\begin{array}{r}127.6 \\
0.0\end{array}$ & $\begin{array}{r}228.6 \\
0.0\end{array}$ & $\begin{array}{r}279.1 \\
0.0\end{array}$ & $\begin{array}{r}256.0 \\
0.0\end{array}$ & $\begin{array}{r}205.0 \\
0.0\end{array}$ & $\begin{array}{r}162.6 \\
0.0\end{array}$ & $\begin{array}{r}135.4 \\
0.0\end{array}$ & $\begin{array}{r}102.8 \\
0.0\end{array}$ \\
\hline EARNINGS BEFORE TAX & 0.0 & -10.9 & -47.4 & -117.3 & -118.0 & -218.5 & -272.2 & -217.0 & -239.6 & -135.5 & -96.4 \\
\hline INCOME TAXES & 0.0 & -4.1 & -17.7 & -43.7 & -44.0 & -81.5 & -101.5 & -81.0 & -89.4 & -50.5 & -36.0 \\
\hline EARNINGS AFTER TAX & 0.0 & -6.8 & -29.7 & -73.5 & .74 .0 & -137.0 & -170.7 & -136.1 & -150.2 & -84.9 & -60.4 \\
\hline $\begin{array}{l}\text { + TAX OEPRECIATION } \\
\text { + DEPLETION } \\
\text { - EQUITY COSTS } \\
\text { - REPLACEMENT COSTS } \\
\text { - INCREASE HORKING CAP }\end{array}$ & $\begin{array}{l}0.0 \\
0.0 \\
0.0 \\
0.0 \\
0.0\end{array}$ & $\begin{array}{r}10.9 \\
0.0 \\
38.0 \\
0.0 \\
0.0\end{array}$ & $\begin{array}{r}47.4 \\
0.0 \\
63.5 \\
0.0 \\
0.0\end{array}$ & $\begin{array}{r}127.6 \\
0.0 \\
176.6 \\
0.0 \\
7.6\end{array}$ & $\begin{array}{r}228.6 \\
0.0 \\
99.6 \\
0.0 \\
23.8\end{array}$ & $\begin{array}{r}279.1 \\
0.0 \\
49.3 \\
0.0 \\
11.7\end{array}$ & $\begin{array}{r}256.0 \\
0.0 \\
0.0 \\
0.0 \\
5.6\end{array}$ & $\begin{array}{r}205.0 \\
0.0 \\
0.0 \\
0.0 \\
2.3\end{array}$ & $\begin{array}{r}162.6 \\
0.0 \\
0.0 \\
0.0 \\
-3.3\end{array}$ & $\begin{array}{r}135.4 \\
0.0 \\
0.0 \\
0.0 \\
8.6\end{array}$ & $\begin{array}{r}102.8 \\
0.0 \\
0.0 \\
0.0 \\
2.8\end{array}$ \\
\hline $\begin{array}{l}\text { NET CASH FLOU } \\
\text { CUM. NET CASH FLOW } \\
\text { NET PRESENT VALUE AT } 20 \% \\
\text { IRR ON EQUITY }\end{array}$ & $\begin{array}{c}0.0 \\
0.0 \\
0.2 \\
20.0 x\end{array}$ & $\begin{array}{l}-33.9 \\
-33.9\end{array}$ & $\begin{array}{l}-45.8 \\
-79.7\end{array}$ & $\begin{array}{l}-130.1 \\
-209.8\end{array}$ & $\begin{array}{r}31.2 \\
-178.6\end{array}$ & $\begin{array}{r}81.0 \\
-97.6\end{array}$ & $\begin{array}{r}79.8 \\
-17.8\end{array}$ & $\begin{array}{l}66.6 \\
48.8\end{array}$ & $\begin{array}{l}15.7 \\
64.5\end{array}$ & $\begin{array}{r}41.9 \\
106.4\end{array}$ & $\begin{array}{r}39.5 \\
145.9\end{array}$ \\
\hline
\end{tabular}


Table $1-5$ (cont inued)

CASH FLOW PROJECTIONS - OX REAL GROWTH

( $S$ millions as spent)

Commercial Plant - Case 1

\begin{tabular}{|c|c|c|c|c|c|c|c|c|c|c|}
\hline $\begin{array}{l}\text { YEAR } \\
\text { PROOUCTION AND PRICES: } \\
\text { OIL PROOUCTION, MMBBL/YR } \\
\text { ANNUAL OIL PRICE }\end{array}$ & $\begin{array}{r}8.44099 \\
50.20\end{array}$ & $\begin{array}{r}8.44099 \\
52.71\end{array}$ & $\begin{array}{r}13 \\
8.44099 \\
55.34\end{array}$ & $\begin{array}{r}14 \\
8.44099 \\
58.11\end{array}$ & $\begin{array}{r}15 \\
8.44099 \\
61.02\end{array}$ & $\begin{array}{r}8.44099 \\
64.07\end{array}$ & $\begin{array}{r}17 \\
8.44099 \\
67.27\end{array}$ & $\begin{array}{r}18 \\
8.44099 \\
70.63\end{array}$ & $\begin{array}{r}19 \\
8.44099 \\
74.17\end{array}$ & $\begin{array}{r}8.44099 \\
77.87\end{array}$ \\
\hline $\begin{array}{l}\text { CASH FLOW: } \\
\text { OIL REVENUES } \\
\text { BY-PROOUCT CREDITS } \\
\text { REVENUES }\end{array}$ & $\begin{array}{r}423.7 \\
36.9 \\
460.7\end{array}$ & $\begin{array}{r}444.9 \\
38.8 \\
483.7\end{array}$ & $\begin{array}{r}467.2 \\
40.7 \\
507.9\end{array}$ & $\begin{array}{r}490.5 \\
42.8 \\
533.3\end{array}$ & $\begin{array}{r}515.0 \\
44.9 \\
560.0\end{array}$ & $\begin{array}{r}540.8 \\
47.2 \\
587.9\end{array}$ & $\begin{array}{r}567.8 \\
49.5 \\
617.3\end{array}$ & $\begin{array}{r}596.2 \\
52.0 \\
648.2\end{array}$ & $\begin{array}{r}626.0 \\
54.6 \\
680.6\end{array}$ & $\begin{array}{r}657.3 \\
57.3 \\
714.7\end{array}$ \\
\hline $\begin{array}{l}0 \text { AND } M \text { COSTS } \\
\text { INTEREST EXPENSE }\end{array}$ & $\begin{array}{l}319.4 \\
128.1\end{array}$ & $\begin{array}{l}335.3 \\
128.1\end{array}$ & & 128.1 & & & & & & $\begin{array}{l}494.8 \\
128.1\end{array}$ \\
\hline MET OPERATING INCOME & 13.2 & 20.3 & -62.6 & 35.6 & 43.9 & 52.6 & 61.6 & -44.1 & 81.2 & 91.7 \\
\hline $\begin{array}{l}\text { TAX DEPRECIATION } \\
\text { DEPLETION }\end{array}$ & $\begin{array}{r}60.0 \\
0.0\end{array}$ & $\begin{array}{r}25.0 \\
0.0\end{array}$ & $\begin{array}{l}8.2 \\
0.0\end{array}$ & $\begin{array}{r}3.7 \\
12.8\end{array}$ & $\begin{array}{r}3.7 \\
16.1\end{array}$ & $\begin{array}{r}3.7 \\
19.5\end{array}$ & $\begin{array}{r}3.7 \\
23.2\end{array}$ & $\begin{array}{l}3.7 \\
0.0\end{array}$ & $\begin{array}{r}3.7 \\
31.0\end{array}$ & $\begin{array}{r}3.7 \\
35.2\end{array}$ \\
\hline EARMINGS BEFORE TAX & -46.8 & -4.7 & -70.7 & 19.2 & 24.1 & 29.3 & 34.8 & -47.8 & 46.5 & 52.8 \\
\hline INCOME TAXES & -17.5 & -1.7 & -26.4 & 7.1 & 9.0 & 10.9 & 13.0 & -17.8 & 17.3 & 19.7 \\
\hline EARNINGS AFTER TAX & -29.4 & -2.9 & -44.3 & 12.0 & 15.1 & 18.4 & 21.8 & -30.0 & 29.2 & 33.1 \\
\hline $\begin{array}{l}\text { + TAX DEPRECIATION } \\
\text { + DEPLETION } \\
\text { - EQUITY COSTS } \\
\text { - REPLACEMENT COSTS } \\
\text { - INCREASE WORKING CAP }\end{array}$ & $\begin{array}{r}60.0 \\
0.0 \\
0.0 \\
0.0 \\
3.0 \\
-\end{array}$ & $\begin{array}{r}25.0 \\
0.0 \\
0.0 \\
0.0 \\
3.1\end{array}$ & $\begin{array}{r}8.2 \\
0.0 \\
0.0 \\
0.0 \\
-4.3\end{array}$ & $\begin{array}{r}3.7 \\
12.8 \\
0.0 \\
0.0 \\
11.0 \\
\end{array}$ & $\begin{array}{r}3.7 \\
16.1 \\
0.0 \\
0.0 \\
3.6\end{array}$ & $\begin{array}{r}3.7 \\
19.5 \\
0.0 \\
0.0 \\
3.8\end{array}$ & $\begin{array}{r}3.7 \\
23.2 \\
0.0 \\
0.0 \\
4.0\end{array}$ & $\begin{array}{r}3.7 \\
0.0 \\
0.0 \\
0.0 \\
-5.4\end{array}$ & $\begin{array}{r}3.7 \\
31.0 \\
0.0 \\
0.0 \\
14.0\end{array}$ & $\begin{array}{r}3.7 \\
35.2 \\
0.0 \\
0.0 \\
4.6\end{array}$ \\
\hline $\begin{array}{l}\text { NET CASH FLON } \\
\text { CUM. NET CASH FLOW } \\
\text { NET PRESENT VALUE AT }\end{array}$ & $\begin{array}{r}27.7 \\
173.6\end{array}$ & $\begin{array}{r}18.9 \\
192.5\end{array}$ & $\begin{array}{l}-31.9 \\
160.6\end{array}$ & $\begin{array}{r}17.5 \\
178.2\end{array}$ & $\begin{array}{r}31.3 \\
209.5\end{array}$ & $\begin{array}{r}37.8 \\
247.3\end{array}$ & $\begin{array}{r}44.7 \\
292.0\end{array}$ & $\begin{array}{l}-20.8 \\
271.2\end{array}$ & $\begin{array}{r}49.9 \\
321.1\end{array}$ & $\begin{array}{r}67.5 \\
388.6\end{array}$ \\
\hline
\end{tabular}

NEI PRESENT VALUE AT $20 X$

IRR ON EQUITY 
Table $1-5$ (continued)

CASH FLOU PROJECTIONS - OX REAL GRONTH

(s millions os spent)

\begin{tabular}{|c|c|c|c|c|c|c|c|c|c|c|c|}
\hline $\begin{array}{l}\text { YEAR } \\
\text { PROOUCTION AND PRICES: } \\
\text { OIL PROOUCTION, MMBBL/YR } \\
\text { ANNUAL OIL PRICE }\end{array}$ & $\begin{array}{r}8.44099 \\
81.77\end{array}$ & $\begin{array}{r}8.44099 \\
85.86\end{array}$ & $\begin{array}{r}23 \\
8.44099 \\
90.15\end{array}$ & $\begin{array}{r}24 \\
8.44099 \\
94.66\end{array}$ & $\begin{array}{r}25 \\
8.44099 \\
99.39\end{array}$ & $\begin{array}{r}26 \\
8.44099 \\
104.36\end{array}$ & $\begin{array}{r}27 \\
8.44099 \\
109.58\end{array}$ & $\begin{array}{r}28 \\
8.44099 \\
115.06\end{array}$ & $\begin{array}{r}29 \\
8.44099 \\
120.81\end{array}$ & $\begin{array}{r}30 \\
8.44099 \\
126.85\end{array}$ & $\begin{array}{r}\text { Total } \\
222.8421\end{array}$ \\
\hline $\begin{array}{l}\text { CASH FLOW: } \\
\text { OIL REVENUES } \\
\text { BY-PROOUCT CREDITS } \\
\text { REVENUES }\end{array}$ & $\begin{array}{r}690.2 \\
60.2 \\
750.4\end{array}$ & $\begin{array}{r}724.7 \\
63.2 \\
787.9\end{array}$ & $\begin{array}{r}760.9 \\
66.4 \\
827.3\end{array}$ & $\begin{array}{r}799.0 \\
69.7 \\
868.7\end{array}$ & $\begin{array}{r}838.9 \\
73.2 \\
912.1\end{array}$ & $\begin{array}{r}880.9 \\
76.8 \\
957.7\end{array}$ & $\begin{array}{r}924.9 \\
80.7 \\
1005.6\end{array}$ & $\begin{array}{r}971.2 \\
84.7 \\
1055.9\end{array}$ & $\begin{array}{r}1019.7 \\
88.9 \\
1108.7\end{array}$ & $\begin{array}{r}1070.7 \\
93.4 \\
1164.1\end{array}$ & $\begin{array}{r}16279.0 \\
1412.9 \\
17691.9\end{array}$ \\
\hline $\begin{array}{l}0 \text { AND M COSTS } \\
\text { INTEREST EXPENSE }\end{array}$ & $\begin{array}{l}519.5 \\
128.1\end{array}$ & $\begin{array}{l}545.4 \\
128.1\end{array}$ & $\begin{array}{l}719.8 \\
128.1\end{array}$ & $\begin{array}{l}601.2 \\
12 B .1\end{array}$ & $\begin{array}{l}631.2 \\
128.1\end{array}$ & $\begin{array}{l}662.7 \\
128.1\end{array}$ & $\begin{array}{l}695.7 \\
128.1\end{array}$ & $\begin{array}{l}730.5 \\
128.1\end{array}$ & $\begin{array}{l}555.0 \\
128.1\end{array}$ & $\begin{array}{l}446.9 \\
128.1\end{array}$ & $\begin{array}{r}12056.9 \\
3209.4\end{array}$ \\
\hline NET OPERATING INCOME & 102.8 & 114.4 & -20.6 & 139.4 & $\$ 52.8$ & 166.9 & 181.7 & 197.3 & 425.6 & 589.1 & 2425.6 \\
\hline $\begin{array}{l}\text { TAX DEPRECIATION } \\
\text { DEPLETION }\end{array}$ & $\begin{array}{r}3.7 \\
39.6\end{array}$ & $\begin{array}{r}3.7 \\
44.3\end{array}$ & $\begin{array}{l}3.7 \\
0.0\end{array}$ & $\begin{array}{r}3.7 \\
54.3\end{array}$ & $\begin{array}{r}3.7 \\
59.6\end{array}$ & $\begin{array}{r}3.7 \\
65.3\end{array}$ & $\begin{array}{r}3.7 \\
71.2\end{array}$ & $\begin{array}{r}3.7 \\
77.4\end{array}$ & $\begin{array}{r}3.7 \\
133.0\end{array}$ & $\begin{array}{r}0.0 \\
139.7\end{array}$ & $\begin{array}{r}1708.0 \\
822.2\end{array}$ \\
\hline EARNINGS BEFORE TAX & 59.5 & 66.4 & -24.3 & 81.4 & 89.5 & 97.9 & 106.8 & 116.2 & 288.8 & 449.4 & -104.6 \\
\hline INCONE TAXES & 22.2 & 24.8 & -9.1 & 30.4 & 33.4 & 36.5 & 39.8 & 43.3 & 107.7 & 167.6 & -39.0 \\
\hline EARNINGS AFTER TAX & 37.3 & 41.6 & -15.2 & 51.0 & 56.1 & 61.4 & 67.0 & 72.8 & 181.1 & 281.8 & -65.6 \\
\hline $\begin{array}{l}+ \text { TAX DEPRECIATION } \\
+ \text { DEPLETION } \\
\text { - EQUITY COSIS } \\
\text { - REPLACEMENT COSTS } \\
\text { - INCREASE WORKING CAP }\end{array}$ & $\begin{array}{r}3.7 \\
39.6 \\
0.0 \\
0.0 \\
4.8 \\
-\cdots\end{array}$ & $\begin{array}{r}3.7 \\
44.3 \\
0.0 \\
0.0 \\
5.1 \\
\end{array}$ & $\begin{array}{r}3.7 \\
0.0 \\
0.0 \\
0.0 \\
-7.0\end{array}$ & $\begin{array}{r}3.7 \\
54.3 \\
0.0 \\
0.0 \\
17.8\end{array}$ & $\begin{array}{r}3.7 \\
59.6 \\
0.0 \\
0.0 \\
5.9\end{array}$ & $\begin{array}{r}3.7 \\
65.3 \\
0.0 \\
0.0 \\
6.1\end{array}$ & $\begin{array}{r}3.7 \\
71.2 \\
0.0 \\
0.0 \\
6.5\end{array}$ & $\begin{array}{r}3.7 \\
77.4 \\
0.0 \\
0.0 \\
6.8\end{array}$ & $\begin{array}{r}3.7 \\
133.0 \\
0.0 \\
0.0 \\
24.8\end{array}$ & $\begin{array}{r}0.0 \\
139.7 \\
0.0 \\
0.0 \\
19.7\end{array}$ & $\begin{array}{r}1708.0 \\
822.2 \\
427.0 \\
0.0 \\
186.6\end{array}$ \\
\hline $\begin{array}{l}\text { NET CASH FLON } \\
\text { CUH. NET CASH FLON } \\
\text { NET PRESENT VALUE AT } 20 X \\
\text { IRR ON EQUITY }\end{array}$ & $\begin{array}{r}75.8 \\
464.4\end{array}$ & $\begin{array}{r}84.6 \\
549.0\end{array}$ & $\begin{array}{r}-4.5 \\
544.4\end{array}$ & $\begin{array}{r}91.2 \\
635.6\end{array}$ & $\begin{array}{l}113.6 \\
749.2\end{array}$ & $\begin{array}{l}124.3 \\
873.5\end{array}$ & $\begin{array}{r}135.5 \\
1008.9\end{array}$ & $\begin{array}{r}147.2 \\
1156.1\end{array}$ & $\begin{array}{r}293.1 \\
1449.2\end{array}$ & $\begin{array}{r}401.8 \\
1851.0\end{array}$ & 1851.0 \\
\hline
\end{tabular}


Table 1-6

CASH FLOW PROJECTIONS - $2 X$ REAL GROUTH

(s millions as spent)

Commercial Plant - Case 1

\begin{tabular}{|c|c|c|c|c|c|c|c|c|c|c|c|}
\hline \multirow{2}{*}{$\begin{array}{l}\text { YEAR } \\
\text { PROOUCTION AND PRICES: } \\
\text { OIL PRCOUCIION, MMBBL/YR } \\
\text { ANNUAL OIL PRICE }\end{array}$} & 0 & 1 & 2 & 3 & 4 & 5 & 6 & 7 & 8 & 9 & 10 \\
\hline & $\begin{array}{r}0 \\
23.35\end{array}$ & $\begin{array}{r}0 \\
25.01\end{array}$ & $\begin{array}{r}0 \\
26.78\end{array}$ & $\begin{array}{r}0.422049 \\
28.69\end{array}$ & $\begin{array}{r}4.220495 \\
30.72\end{array}$ & $\begin{array}{r}7.174841 \\
32.90\end{array}$ & $\begin{array}{r}8.44099 \\
35.26\end{array}$ & $\begin{array}{r}8.44099 \\
37.74\end{array}$ & $\begin{array}{r}8.44099 \\
40.42\end{array}$ & $\begin{array}{r}8.44099 \\
43.29\end{array}$ & $\begin{array}{r}8.44099 \\
46.36\end{array}$ \\
\hline $\begin{array}{l}\text { CASH FLOW; } \\
\text { OIL REVENUES } \\
\text { BY-PROOUCT CREDITS } \\
\text { REVENUES }\end{array}$ & $\begin{array}{l}0.0 \\
0.0 \\
0.0\end{array}$ & $\begin{array}{l}0.0 \\
0.0 \\
0.0\end{array}$ & $\begin{array}{l}0.0 \\
0.0 \\
0.0\end{array}$ & $\begin{array}{r}12.1 \\
0.0 \\
12.1\end{array}$ & $\begin{array}{r}129.7 \\
10.5 \\
140.2\end{array}$ & $\begin{array}{r}236.1 \\
20.7 \\
256.8\end{array}$ & $\begin{array}{r}297.5 \\
29.0 \\
326.4\end{array}$ & $\begin{array}{r}318.6 \\
30.4 \\
349.0\end{array}$ & $\begin{array}{r}341.2 \\
31.9 \\
373.1\end{array}$ & $\begin{array}{r}365.4 \\
33.5 \\
398.9\end{array}$ & $\begin{array}{r}391.4 \\
35.2 \\
426.5\end{array}$ \\
\hline $\begin{array}{l}\text { O AND M COSTS } \\
\text { INTEREST EXPENSE }\end{array}$ & 0.0 & 0.0 & 0.0 & 4.0 & 50.1 & $\begin{array}{r}221.3 \\
7.0\end{array}$ & $\begin{array}{l}248.3 \\
128.1\end{array}$ & $\begin{array}{l}262.4 \\
128.1\end{array}$ & $\begin{array}{l}346.4 \\
128.1\end{array}$ & $\begin{array}{l}289.4 \\
128.1\end{array}$ & $\begin{array}{l}304.0 \\
128.1\end{array}$ \\
\hline NET OPERATING INCOME & 0.0 & 0.0 & 0.0 & 8.1 & 90.1 & 28.5 & -50.0 & -41.5 & -101.4 & -18.6 & -5.6 \\
\hline $\begin{array}{l}\text { TAX DEPRECIATION } \\
\text { DEPLETION }\end{array}$ & $\begin{array}{l}0.0 \\
0.0\end{array}$ & $\begin{array}{r}10.9 \\
0.0 \\
0 .\end{array}$ & $\begin{array}{r}47.4 \\
0.0 \\
\end{array}$ & $\begin{array}{r}127.6 \\
0.0 \\
\end{array}$ & $\begin{array}{r}228.6 \\
0.0\end{array}$ & $\begin{array}{r}279.1 \\
0.0\end{array}$ & $\begin{array}{r}256.0 \\
0.0\end{array}$ & $\begin{array}{r}205.0 \\
0.0\end{array}$ & $\begin{array}{r}162.6 \\
0.0\end{array}$ & $\begin{array}{r}135.4 \\
0.0\end{array}$ & $\begin{array}{r}102.8 \\
0.0\end{array}$ \\
\hline EARNINGS BEFORE TAX & 0.0 & -10.9 & -47.4 & -119.5 & -138.5 & -250.6 & -306.1 & -246.5 & -263.9 & -154.0 & -108.3 \\
\hline INCOME TAXES & 0.0 & -4.1 & -17.7 & -44.6 & -51.7 & -93.5 & -114.2 & -91.9 & -98.4 & -57.4 & -40.4 \\
\hline EARNINGS AFTER TAX & 0.0 & -6.8 & -29.7 & -74.9 & -86.8 & -157.1 & -191.9 & -154.5 & -165.5 & .96 .6 & -67.9 \\
\hline $\begin{array}{l}\text { + TAX DEPRECIATION } \\
\text { + DEPLETION } \\
\text { - EQUITY COSTS } \\
\text { - REPLACEMENT COSTS } \\
\text { - INCREASE WORKING CAP }\end{array}$ & $\begin{array}{l}0.0 \\
0.0 \\
0.0 \\
0.0 \\
0.0\end{array}$ & $\begin{array}{r}10.9 \\
0.0 \\
38.0 \\
0.0 \\
0.0\end{array}$ & $\begin{array}{r}47.6 \\
0.0 \\
63.5 \\
0.0 \\
0.0\end{array}$ & $\begin{array}{r}127.6 \\
0.0 \\
176.6 \\
0.0 \\
7.4\end{array}$ & $\begin{array}{r}228.6 \\
0.0 \\
99.6 \\
0.0 \\
22.3\end{array}$ & $\begin{array}{r}279.1 \\
0.0 \\
49.3 \\
0.0 \\
10.8\end{array}$ & $\begin{array}{r}256.0 \\
0.0 \\
0.0 \\
0.0 \\
5.4\end{array}$ & $\begin{array}{r}205.0 \\
0.0 \\
0.0 \\
0.0 \\
2.7\end{array}$ & $\begin{array}{r}162.6 \\
0.0 \\
0.0 \\
0.0 \\
-2.9 \\
\end{array}$ & $\begin{array}{r}135.4 \\
0.0 \\
0.0 \\
0.0 \\
9.1 \\
. . .\end{array}$ & $\begin{array}{r}102.8 \\
0.0 \\
0.0 \\
0.0 \\
3.4\end{array}$ \\
\hline $\begin{array}{l}\text { MET CASH FLON } \\
\text { CUM. NET CASH FLON }\end{array}$ & $\begin{array}{l}0.0 \\
0.0\end{array}$ & $\begin{array}{l}-33.9 \\
-33.9\end{array}$ & $\begin{array}{l}-45.8 \\
-79.7\end{array}$ & $\begin{array}{l}-131.3 \\
-211.0\end{array}$ & $\begin{array}{r}19.9 \\
-191.2\end{array}$ & $\begin{array}{r}61.9 \\
-129.3\end{array}$ & $\begin{array}{r}58.7 \\
-70.6\end{array}$ & $\begin{array}{r}47.7 \\
-22.8\end{array}$ & $\begin{array}{r}0.0 \\
-22.8\end{array}$ & $\begin{array}{r}29.8 \\
6.9\end{array}$ & $\begin{array}{l}31.5 \\
38.4\end{array}$ \\
\hline
\end{tabular}


Table 1-6 (continued)

CASH FLOW PROJECTIONS - $2 X$ REAL GROWTH

(s millions as spent)

Cormercial Plant - Case 1

\begin{tabular}{|c|c|c|c|c|c|c|c|c|c|c|}
\hline $\begin{array}{l}\text { YEAR } \\
\text { PROOUCTION ANO PRICES: } \\
\text { OIL PROOUCTION, MMBBL/YR } \\
\text { ANNUAL OIL PRICE }\end{array}$ & $\begin{array}{r}8.44099 \\
49.66\end{array}$ & $\begin{array}{r}8.44099 \\
53.18\end{array}$ & $\begin{array}{r}13 \\
8.44099 \\
56.96\end{array}$ & $\begin{array}{r}8.44099 \\
61.00\end{array}$ & $\begin{array}{r}15 \\
8.44099 \\
65.33\end{array}$ & $\begin{array}{r}16 \\
8.44099 \\
69.97\end{array}$ & $\begin{array}{r}17 \\
8.44099 \\
74.94\end{array}$ & $\begin{array}{r}18 \\
8.44099 \\
80.26\end{array}$ & $\begin{array}{r}19 \\
8.44099 \\
85.96\end{array}$ & $\begin{array}{r}20 \\
8.44099 \\
92.06\end{array}$ \\
\hline $\begin{array}{l}\text { CASH FLOW; } \\
\text { OIL REVENUES } \\
\text { BY-PROOUCT CREOITS } \\
\text { REVENUES }\end{array}$ & $\begin{array}{r}419.1 \\
36.9 \\
456.1\end{array}$ & $\begin{array}{r}448.9 \\
38.8 \\
487.7\end{array}$ & $\begin{array}{r}480.8 \\
40.7 \\
521.5\end{array}$ & $\begin{array}{r}514.9 \\
42.8 \\
557.7\end{array}$ & $\begin{array}{r}551.5 \\
44.9 \\
598.4\end{array}$ & $\begin{array}{r}590.6 \\
47.2 \\
637.8\end{array}$ & $\begin{array}{r}632.6 \\
49.5 \\
682.1\end{array}$ & $\begin{array}{r}677.5 \\
52.0 \\
729.5\end{array}$ & $\begin{array}{r}725.6 \\
54.6 \\
780.2\end{array}$ & $\begin{array}{r}777.1 \\
57.3 \\
834.4\end{array}$ \\
\hline $\begin{array}{l}\text { O ANO M COSTS } \\
\text { INTEREST EXPENSE }\end{array}$ & $\begin{array}{l}319.3 \\
128.1\end{array}$ & $\begin{array}{l}335.4 \\
128.1\end{array}$ & $\begin{array}{l}442.6 \\
128.1\end{array}$ & $\begin{array}{l}370.0 \\
128.1\end{array}$ & $\begin{array}{l}388.7 \\
128.1\end{array}$ & $\begin{array}{l}408.3 \\
128.1\end{array}$ & $\begin{array}{l}428.9 \\
128.1\end{array}$ & $\begin{array}{l}565.8 \\
128.1\end{array}$ & $\begin{array}{l}473.3 \\
128.1\end{array}$ & $\begin{array}{l}497.2 \\
128.1\end{array}$ \\
\hline MET OPERATING INCOME & 8.7 & 24.2 & -49.2 & 59.6 & 79.6 & 101.6 & 125.1 & 35.5 & 178.8 & 209.1 \\
\hline $\begin{array}{l}\text { TAX DEPRECIATION } \\
\text { DEPLETION }\end{array}$ & $\begin{array}{r}60.0 \\
0.0\end{array}$ & $\begin{array}{r}25.0 \\
0.0\end{array}$ & $\begin{array}{l}8.2 \\
0.0\end{array}$ & $\begin{array}{r}3.7 \\
22.3\end{array}$ & $\begin{array}{r}3.7 \\
30.4\end{array}$ & $\begin{array}{r}3.7 \\
39.1\end{array}$ & $\begin{array}{r}3.7 \\
48.6\end{array}$ & $\begin{array}{r}3.7 \\
12.7\end{array}$ & $\begin{array}{r}3.7 \\
70.0\end{array}$ & $\begin{array}{r}3.7 \\
82.2\end{array}$ \\
\hline EARNINGS BEFORE TAX & -51.3 & -0.8 & -57.4 & 33.5 & 45.5 & 58.6 & 72.8 & 19.1 & 105.1 & 123.3 \\
\hline INCOME TAXES & -19.1 & -0.3 & -21.4 & 12.5 & 17.0 & 21.9 & 27.2 & 7.1 & 39.2 & 46.0 \\
\hline EARNINGS AFTER TAX & -32.2 & -0.5 & -36.0 & 21.0 & 28.5 & 36.8 & 45.7 & 12.0 & 65.9 & $\pi .3$ \\
\hline $\begin{array}{l}\text { + TAX DEPRECIATION } \\
\text { + DEPLEYION } \\
\text { - EQUITY COSTS } \\
\text { - REPLACEMENT COSTS } \\
\text { - INCREASE WORKING CAP }\end{array}$ & $\begin{array}{r}60.0 \\
0.0 \\
0.0 \\
0.0 \\
3.6\end{array}$ & $\begin{array}{r}25.0 \\
0.0 \\
0.0 \\
0.0 \\
3.8\end{array}$ & $\begin{array}{r}8.2 \\
0.0 \\
0.0 \\
0.0 \\
-3.5\end{array}$ & $\begin{array}{r}3.7 \\
22.3 \\
0.0 \\
0.0 \\
11.8\end{array}$ & $\begin{array}{r}3.7 \\
30.4 \\
0.0 \\
0.0 \\
4.6\end{array}$ & $\begin{array}{r}3.7 \\
39.1 \\
0.0 \\
0.0 \\
4.9\end{array}$ & $\begin{array}{r}3.7 \\
48.6 \\
0.0 \\
0.0 \\
5.2\end{array}$ & $\begin{array}{r}3.7 \\
12.7 \\
0.0 \\
0.0 \\
-4.1\end{array}$ & $\begin{array}{r}3.7 \\
70.0 \\
0.0 \\
0.0 \\
15.5\end{array}$ & $\begin{array}{r}3.7 \\
82.2 \\
0.0 \\
0.0 \\
6.2\end{array}$ \\
\hline $\begin{array}{l}\text { NET CASH FLOW } \\
\text { CUM. NET CASH F }\end{array}$ & $\begin{array}{l}24.3 \\
62.7\end{array}$ & $\begin{array}{l}20.7 \\
83.4\end{array}$ & $\begin{array}{r}-24.3 \\
59.1\end{array}$ & $\begin{array}{l}35.2 \\
94.3\end{array}$ & $\begin{array}{r}58.0 \\
152.3\end{array}$ & $\begin{array}{r}74.7 \\
227.0\end{array}$ & $\begin{array}{r}92.8 \\
319.8\end{array}$ & $\begin{array}{r}32.5 \\
352.3\end{array}$ & $\begin{array}{l}124.2 \\
476.4\end{array}$ & $\begin{array}{l}156.9 \\
633.4\end{array}$ \\
\hline
\end{tabular}

CUM. NET CASH FLOW

IRR ON EOUITY 
Table 1.6 (CONTINUED)

CASH FLON PROJECTIONS - $2 \%$ REAL GROWTH

(S MILLIONS AS SPENT)

\begin{tabular}{|c|c|c|c|c|c|c|c|c|c|c|c|}
\hline $\begin{array}{l}\text { YEAR } \\
\text { PROOUCTION AND PRICES: } \\
\text { OIL PROOUCTION,MMBBL/YR } \\
\text { ANNUAL OIL PRICE }\end{array}$ & $\begin{array}{r}8.44099 \\
98.60\end{array}$ & $\begin{array}{r}8.44099 \\
105.60\end{array}$ & $\begin{array}{r}23 \\
8.44099 \\
113.10\end{array}$ & $\begin{array}{r}8.44099 \\
i 21.13\end{array}$ & $\begin{array}{r}25 \\
8.44099 \\
129.72\end{array}$ & $\begin{array}{r}26 \\
8.44099 \\
138.94\end{array}$ & $\begin{array}{r}27 \\
8.44099 \\
148.80\end{array}$ & $\begin{array}{r}28 \\
8.44099 \\
159.36\end{array}$ & $\begin{array}{r}29 \\
8.44099 \\
170.68\end{array}$ & $\begin{array}{r}30 \\
8.44099 \\
182.80\end{array}$ & $\begin{array}{r}\text { Total } \\
222.8421\end{array}$ \\
\hline $\begin{array}{l}\text { CASH FLOH; } \\
\text { OIL REVENUES } \\
\text { BY-PROOUCT CREDITS } \\
\text { REVENUES }\end{array}$ & $\begin{array}{r}832.3 \\
60.2 \\
892.4\end{array}$ & $\begin{array}{r}891.4 \\
63.2 \\
954.5\end{array}$ & $\begin{array}{r}954.6 \\
66.4 \\
1021.0\end{array}$ & $\begin{array}{r}1022.4 \\
69.7 \\
1092.1\end{array}$ & $\begin{array}{r}1095.0 \\
73.2 \\
1168.2\end{array}$ & $\begin{array}{r}1172.8 \\
76.8 \\
1249.6\end{array}$ & $\begin{array}{r}1256.0 \\
80.7 \\
1336.7\end{array}$ & $\begin{array}{r}1345.2 \\
84.7 \\
1429.9\end{array}$ & $\begin{array}{r}1440.7 \\
88.9 \\
1529.6\end{array}$ & $\begin{array}{r}1543.0 \\
93.4 \\
1636.4\end{array}$ & $\begin{array}{r}19463.7 \\
1412.9 \\
20876.6\end{array}$ \\
\hline $\begin{array}{l}0 \text { AND M COSTS } \\
\text { INTEREST EXPENSE }\end{array}$ & $\begin{array}{l}522.3 \\
128.1\end{array}$ & $\begin{array}{l}548.7 \\
128.1\end{array}$ & $\begin{array}{l}3.6 \\
8.1\end{array}$ & $\begin{array}{l}605.6 \\
128.1\end{array}$ & & & & & & $\begin{array}{l}456.2 \\
128.1\end{array}$ & \\
\hline NET OPERATING INCOME & 242.1 & 277.8 & 169.3 & 358.4 & 403.9 & 453.1 & 506.3 & 564.0 & 838.3 & 1052.1 & 5547.7 \\
\hline $\begin{array}{l}\text { TAX OEPRECIATION } \\
\text { DEPLETION }\end{array}$ & $\begin{array}{r}3.7 \\
95.3\end{array}$ & $\begin{array}{r}3.7 \\
109.6\end{array}$ & $\begin{array}{r}3.7 \\
66.2\end{array}$ & $\begin{array}{r}3.7 \\
131.9\end{array}$ & $\begin{array}{r}3.7 \\
140.2\end{array}$ & $\begin{array}{r}3.7 \\
149.9\end{array}$ & $\begin{array}{r}3.7 \\
160.4\end{array}$ & $\begin{array}{r}3.7 \\
171.6\end{array}$ & $\begin{array}{r}3.7 \\
183.6\end{array}$ & $\begin{array}{r}0.0 \\
196.4\end{array}$ & \\
\hline EARNIMGS BEFORE TAX & 143.0 & 164.4 & 99.4 & 223.7 & 260.0 & 299.4 & 342.2 & 388.7 & 651.0 & 855.7 & 2130.1 \\
\hline INCOME TAXES & 53.3 & 61.3 & 37.1 & 83.4 & 97.0 & 111.7 & 127.6 & 145.0 & 242.8 & 319.2 & 794.5 \\
\hline EARNINGS AFTER TAX & 89.7 & 103.1 & 62.3 & 140.2 & 163.0 & 187.7 & 214.6 & 243.7 & 408.2 & 536.5 & 1335.6 \\
\hline $\begin{array}{l}\text { + TAX OEPRECIATION } \\
\text { + DEPLEYION } \\
\text { - EQUITY COSTS } \\
\text { - REPLACEMENT COSIS } \\
\text { - INCREASE WORKING CAP }\end{array}$ & $\begin{array}{r}3.7 \\
95.3 \\
0.0 \\
0.0 \\
6.6 \\
0.0\end{array}$ & $\begin{array}{r}3.7 \\
109.6 \\
0.0 \\
0.0 \\
7.1\end{array}$ & $\begin{array}{r}3.7 \\
66.2 \\
0.0 \\
0.0 \\
-4.7\end{array}$ & $\begin{array}{r}3.7 \\
131.1 \\
0.0 \\
0.0 \\
20.3\end{array}$ & $\begin{array}{r}3.7 \\
140.2 \\
0.0 \\
0.0 \\
8.5\end{array}$ & $\begin{array}{r}3.7 \\
149.9 \\
0.0 \\
0.0 \\
9.1\end{array}$ & $\begin{array}{r}3.7 \\
160.4 \\
0.0 \\
0.0 \\
9.7\end{array}$ & $\begin{array}{r}3.7 \\
171.6 \\
0.0 \\
0.0 \\
10.3\end{array}$ & $\begin{array}{r}3.7 \\
183.6 \\
0.0 \\
0.0 \\
28.6\end{array}$ & $\begin{array}{r}0.0 \\
196.4 \\
0.0 \\
0.0 \\
23.9\end{array}$ & $\begin{array}{r}1708.0 \\
1709.6 \\
427.0 \\
0.0 \\
225.2\end{array}$ \\
\hline $\begin{array}{l}\text { NET CASH FLON } \\
\text { CUM. NET CASH FLON }\end{array}$ & $\begin{array}{l}182.1 \\
815.5\end{array}$ & $\begin{array}{r}209.4 \\
1024.8\end{array}$ & $\begin{array}{r}137.0 \\
1161.9\end{array}$ & $\begin{array}{r}254.7 \\
1416.6\end{array}$ & $\begin{array}{r}298.4 \\
1715.0\end{array}$ & $\begin{array}{r}332.3 \\
2047.3\end{array}$ & $\begin{array}{r}369.0 \\
2416.3\end{array}$ & $\begin{array}{r}408.7 \\
2825.0\end{array}$ & $\begin{array}{r}566.8 \\
3391.9\end{array}$ & $\begin{array}{r}709.0 \\
4100.9\end{array}$ & 4100.9 \\
\hline
\end{tabular}

NET PRESENT VALUE AT $20 \%$

IRR ON EQUITY 
Table 1-7

OVERall material balance - CASE 1

COMMERCIAL PLANT

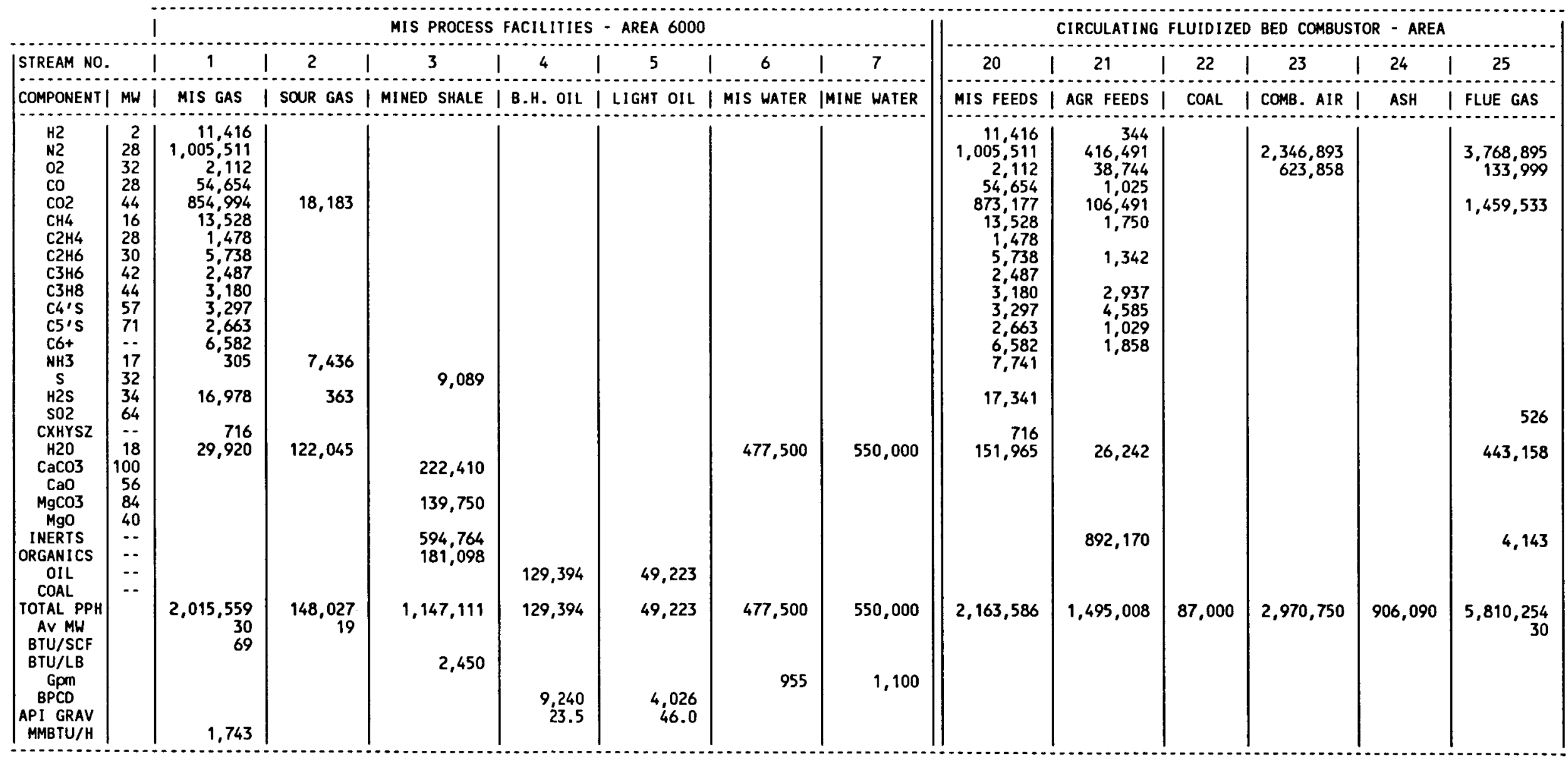


Table 1-7 (Cont inued)

OVERALL material baLANCE - CASE 1

COMMERCIAL PLANT

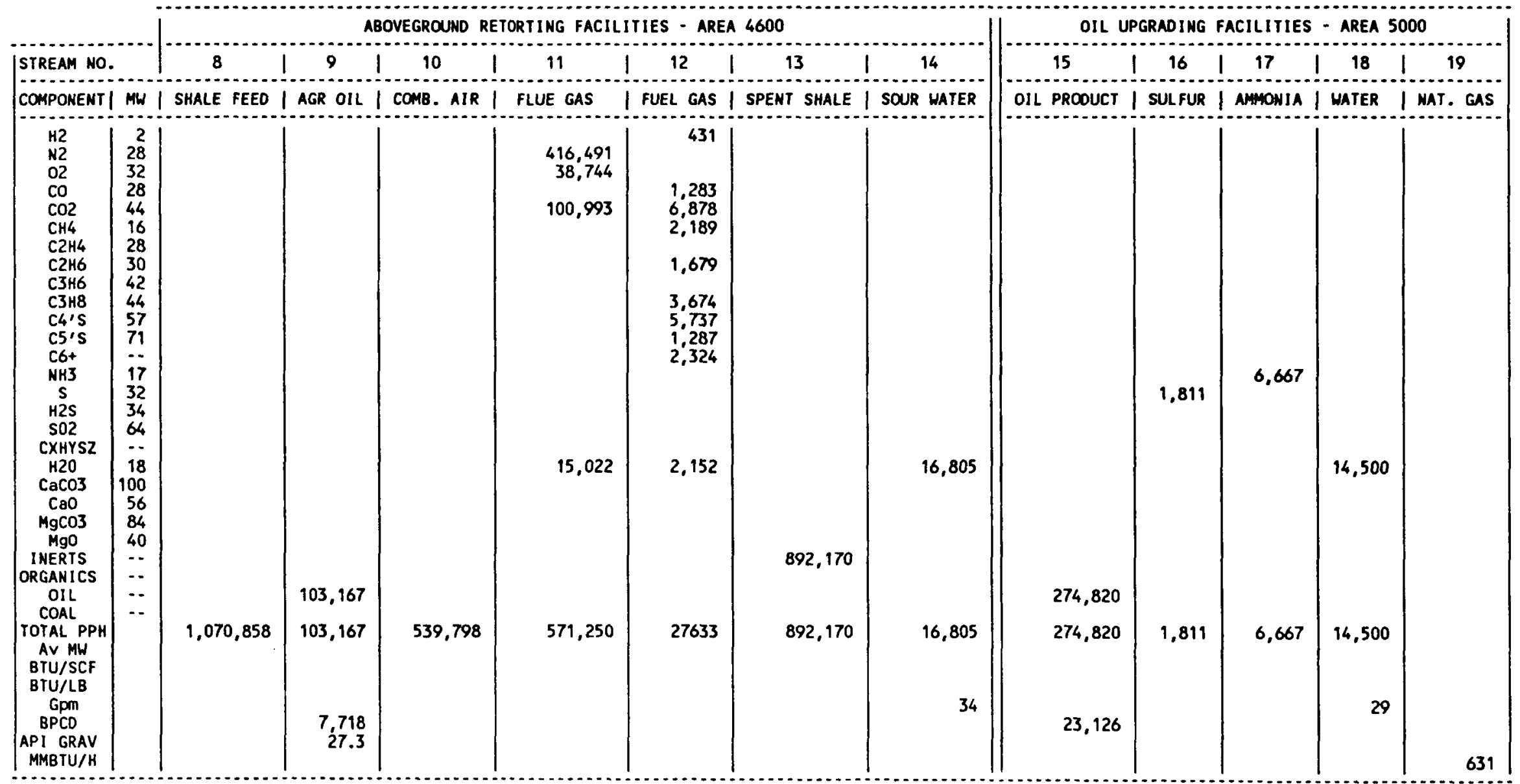


Table 1-8

OVERALL MATERIAL baLANCE - CASE 2

DEMONSTRATION PLANT

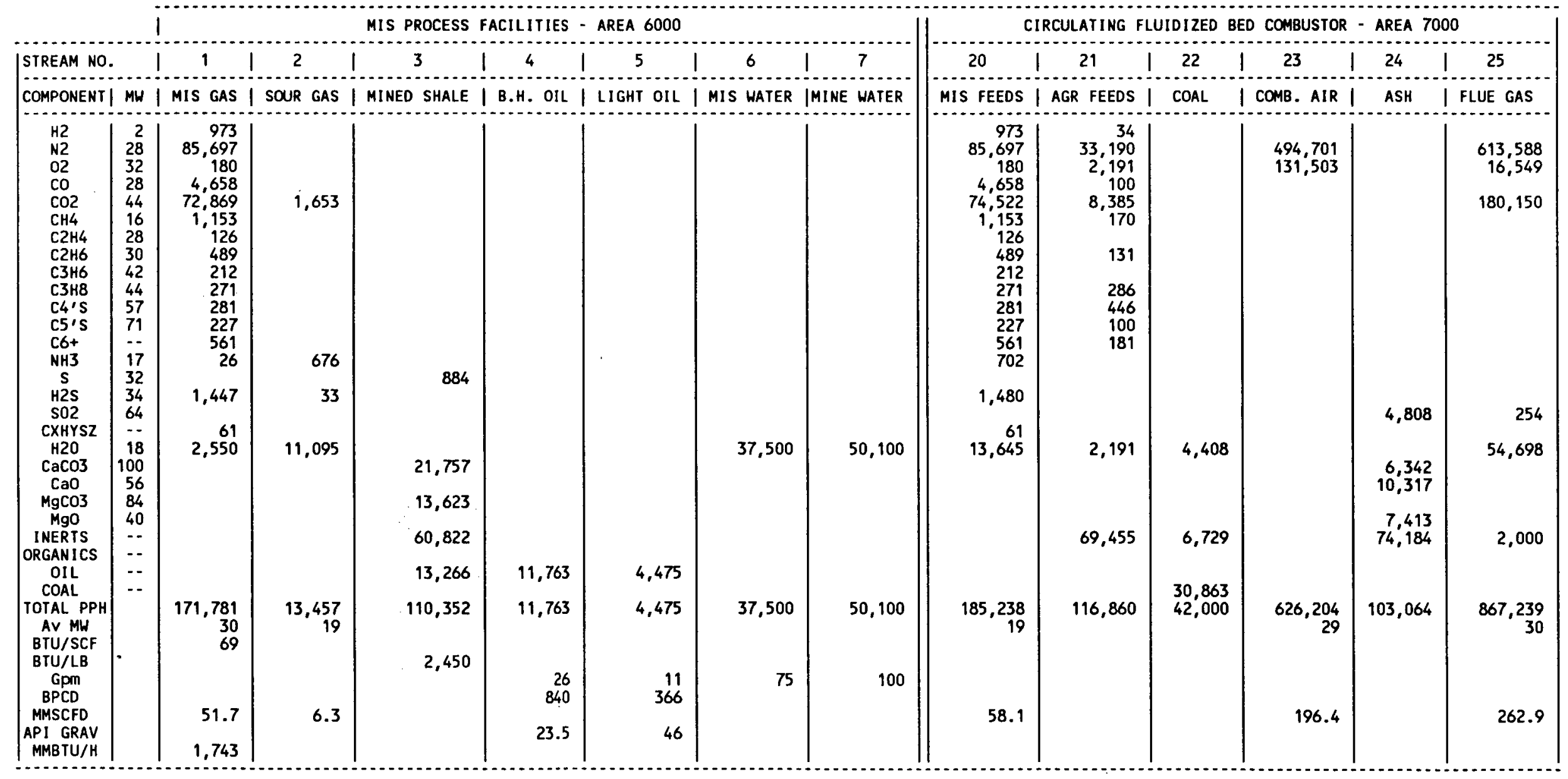


Table 1-8 (Cont inued)

OVERALL MATERIAL BALANCE - CASE 2

DEMONSTRATION PLANT

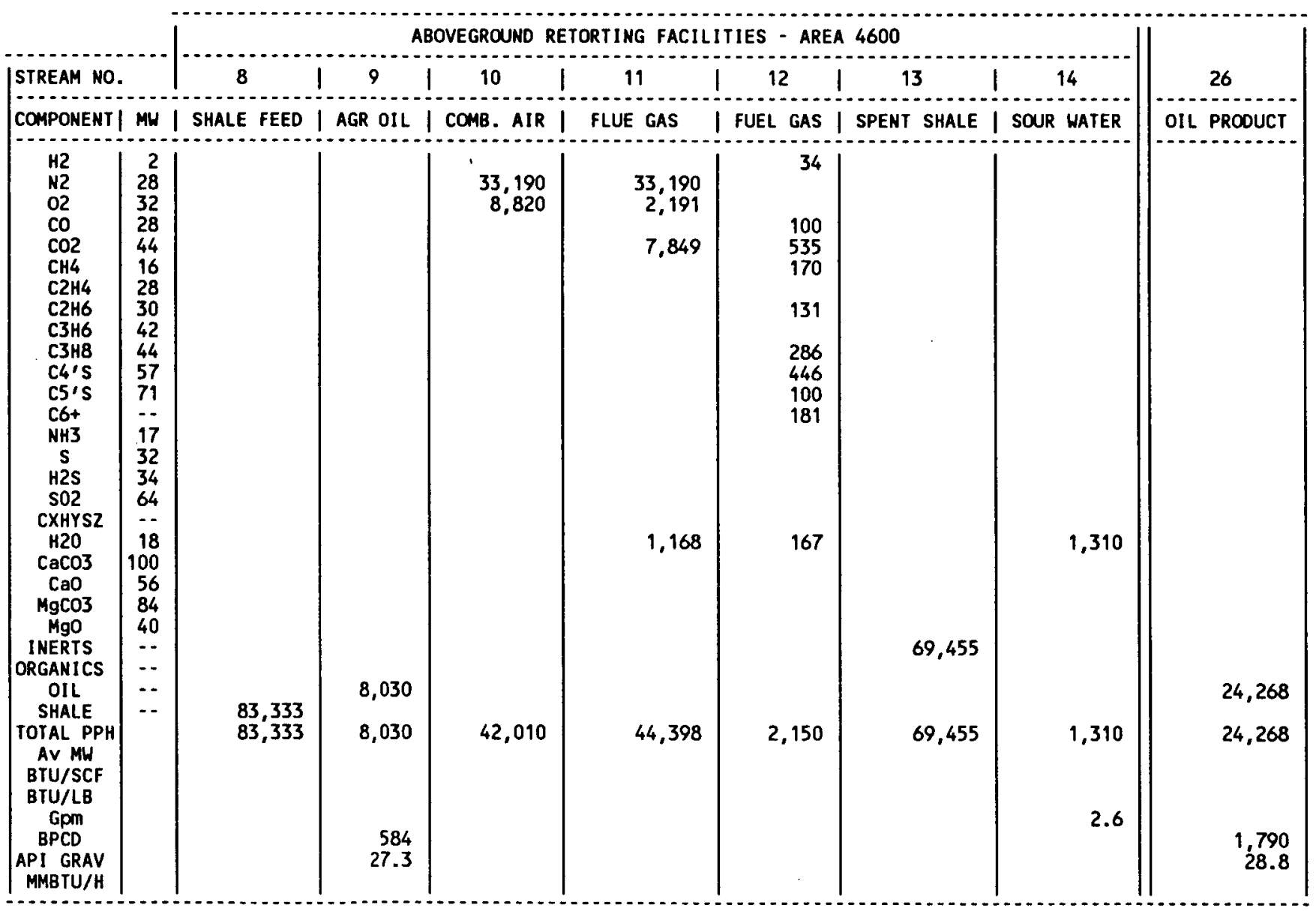


Figure 1-1

PROJECT SCHEDULE

CASE 1 - COMMERICAL

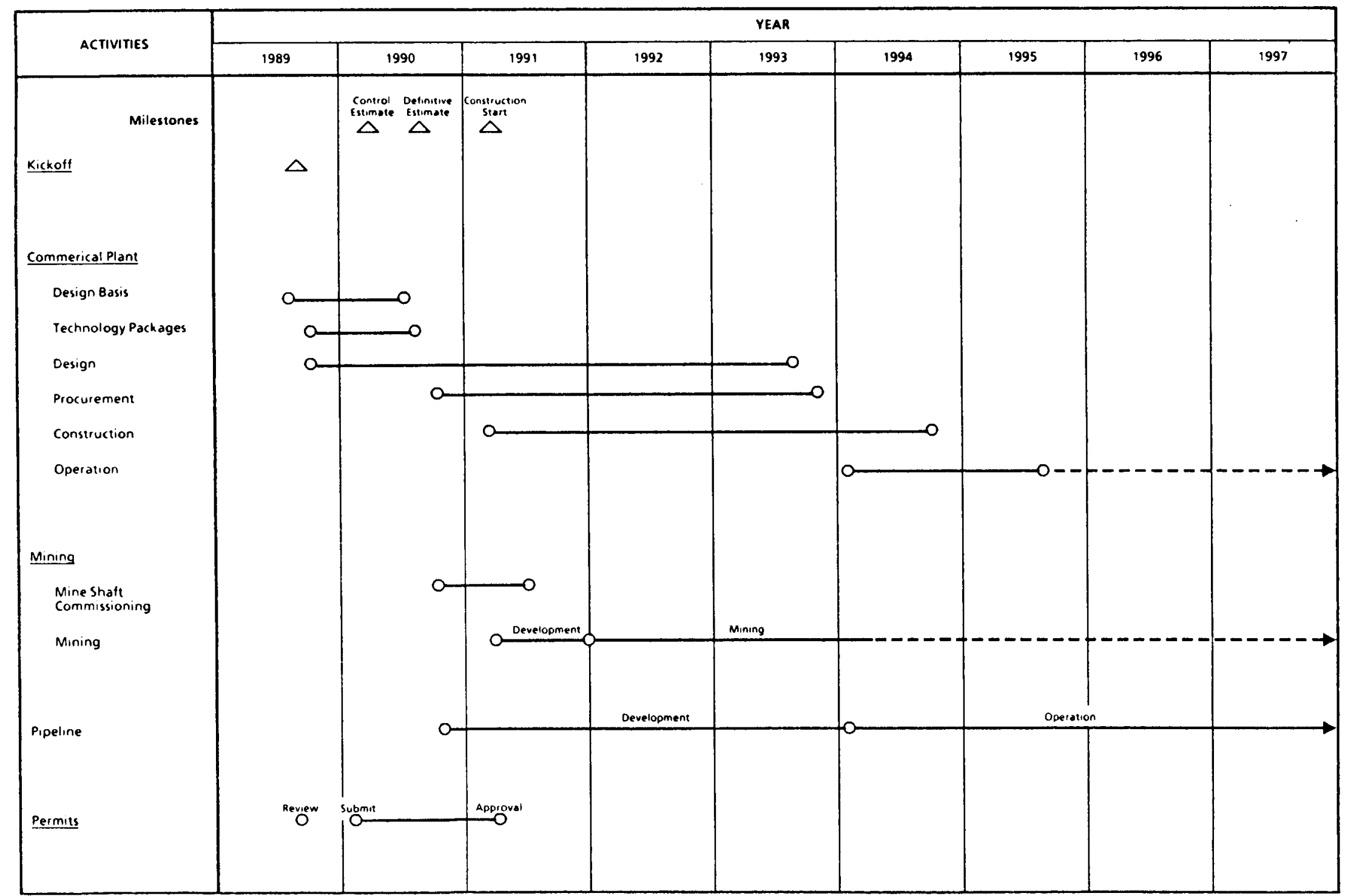


Figure 1-2

PROJECT SCHEDULE

CASE 2 AND $2 A$ - DEMONSTRATION

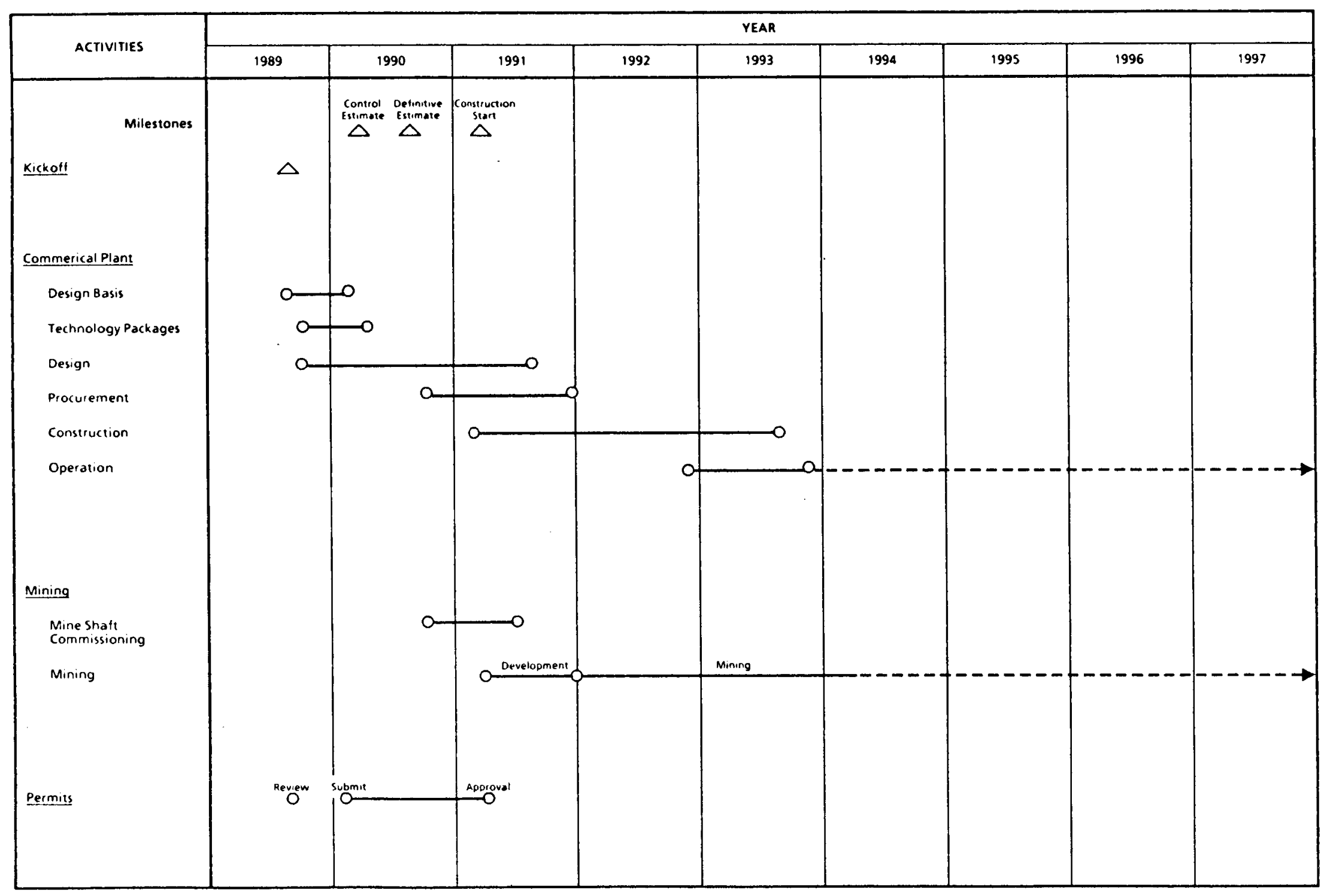


Figure 1-3

PROJECT SCHEDULE

CASE 3 - PILOT PLANT

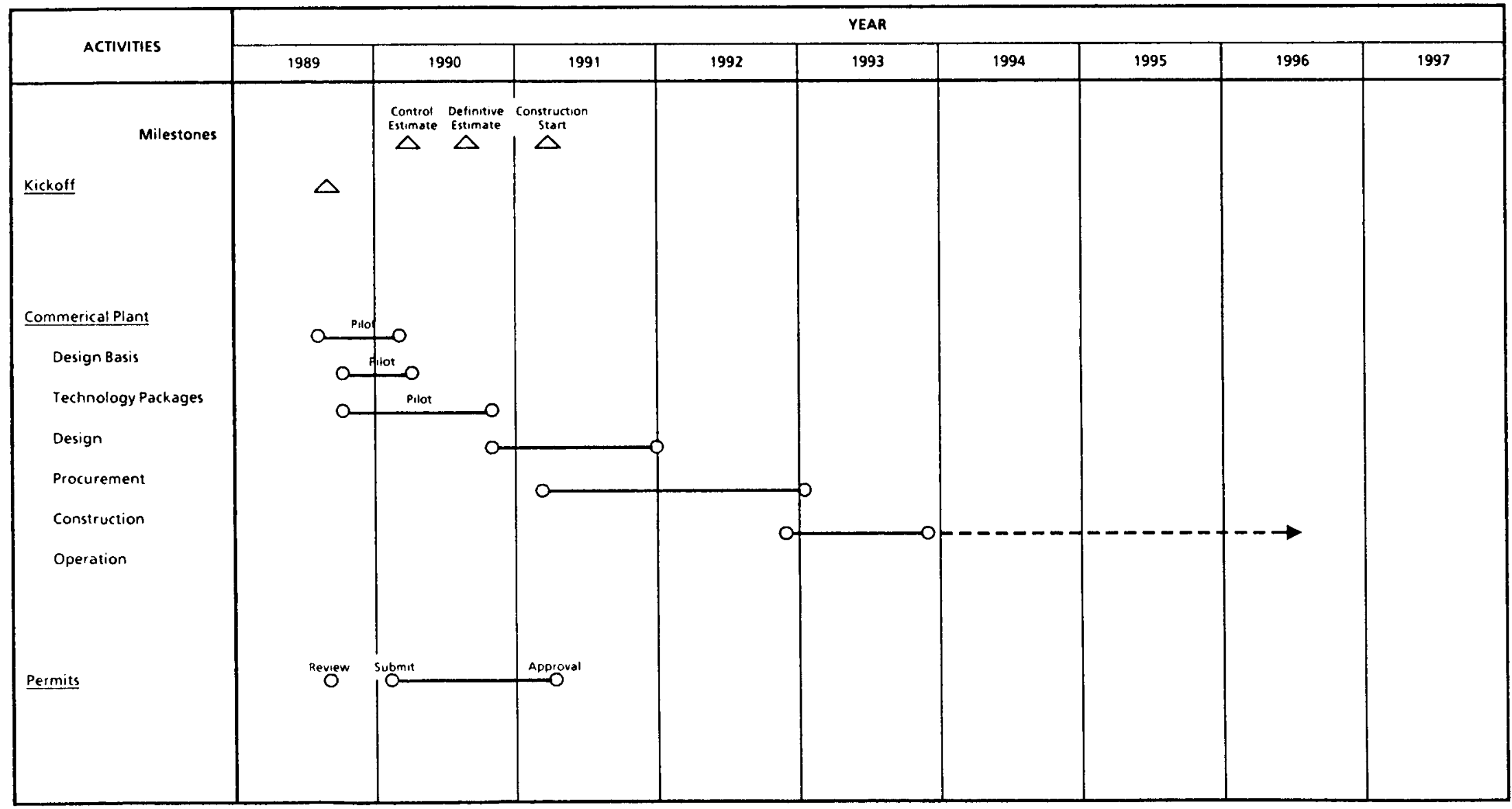


Figure 1.4

PRE-COMMERCIALIZATION SCHEDULE

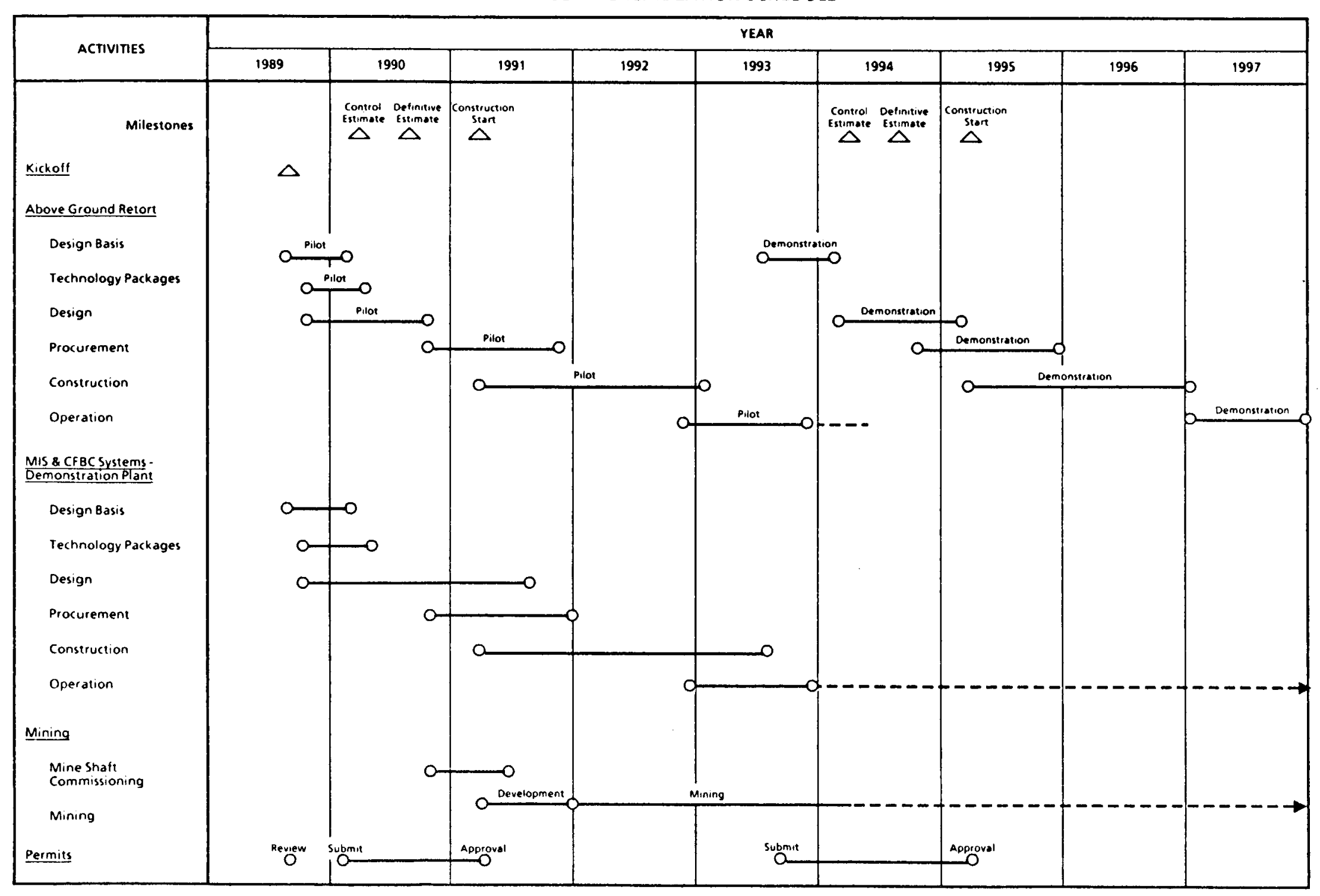


Figure 1-5

COMMERCIAL SHALE OIL ECONOMICS

IRR VS OIL PRICE - Case 1

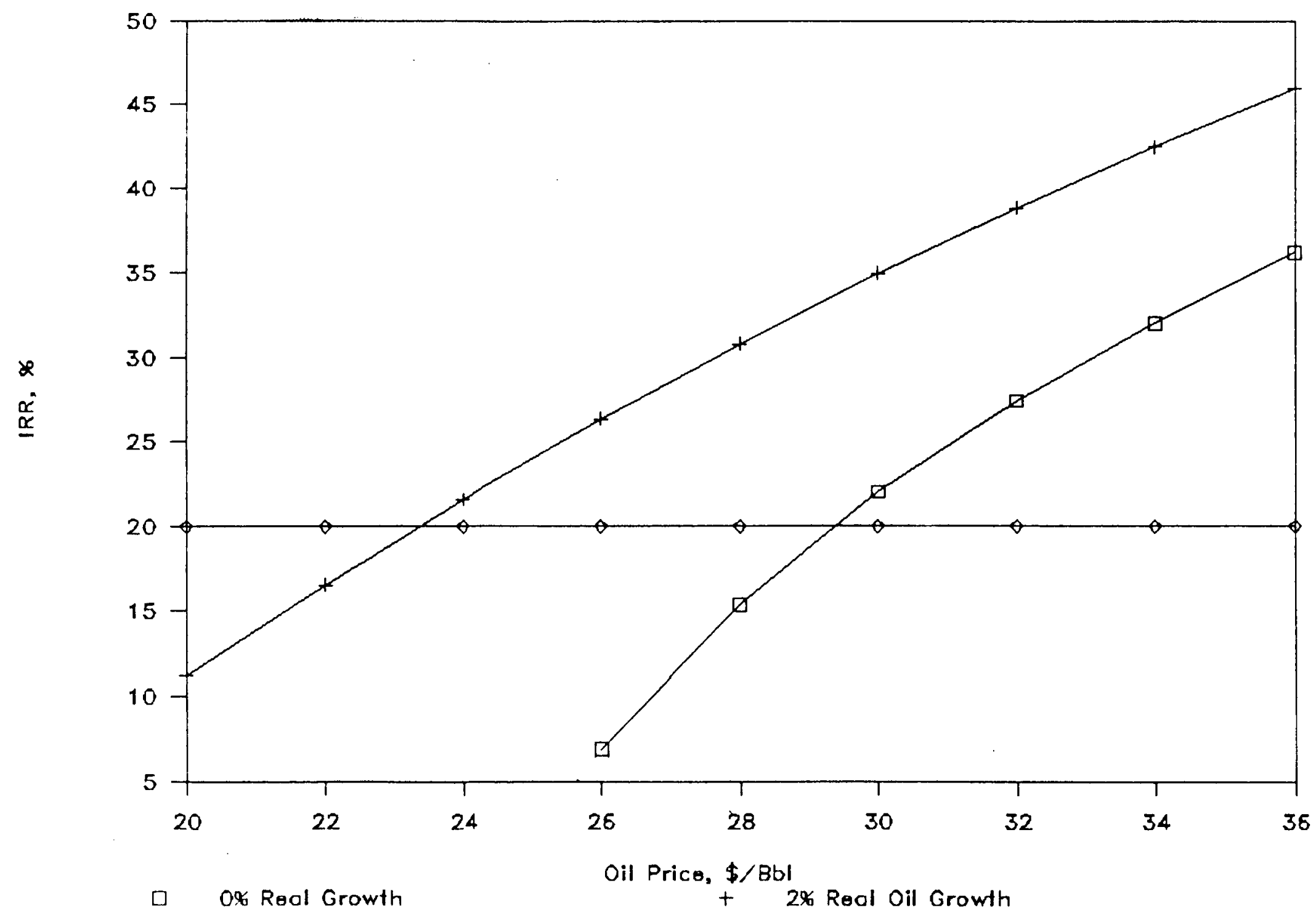


Figure 1-6

BLOCKFLOW DIAGRAM

COMMERICAL SIZE PLANT

CASE I

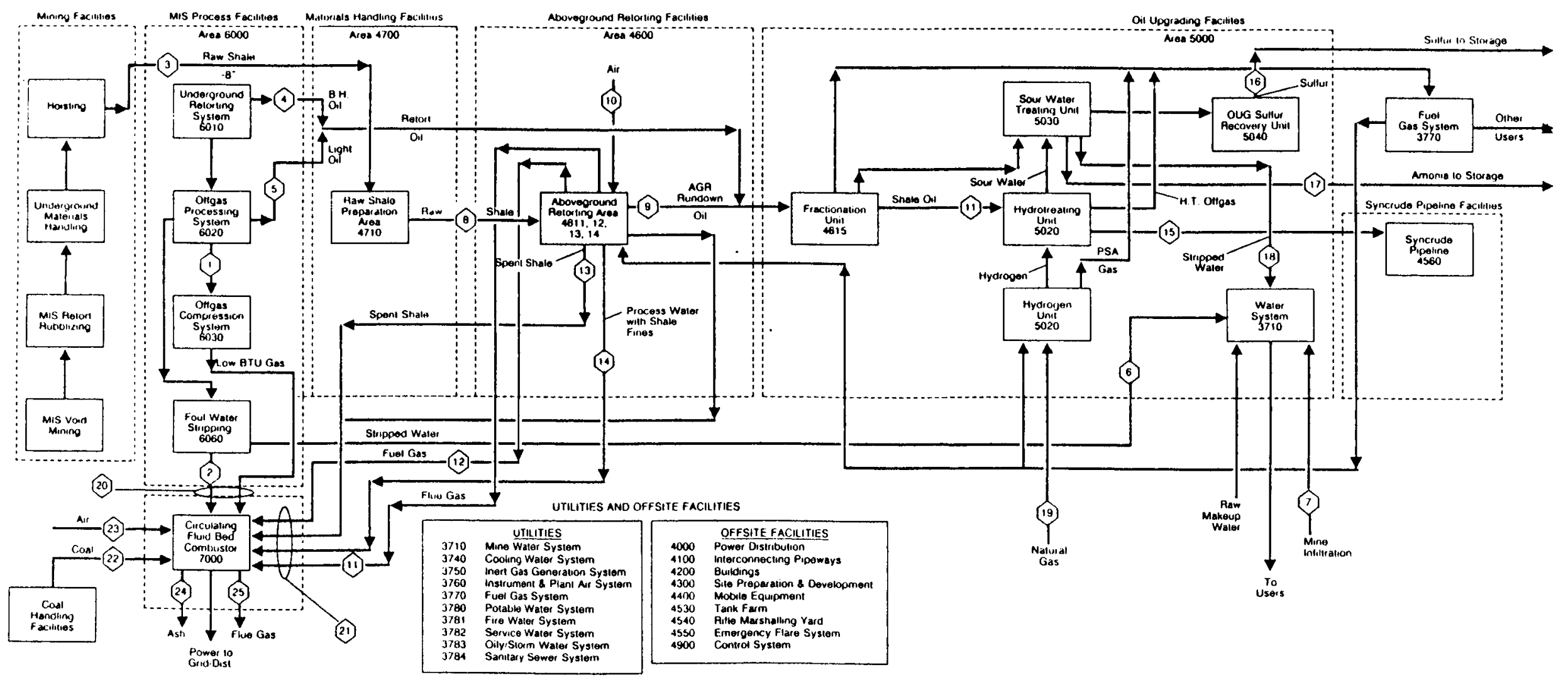


Figure 1-7

BLOCK FLOW DIAGRAM

DEMONSTRATION SIZE PLANT

CASES 2, 2A

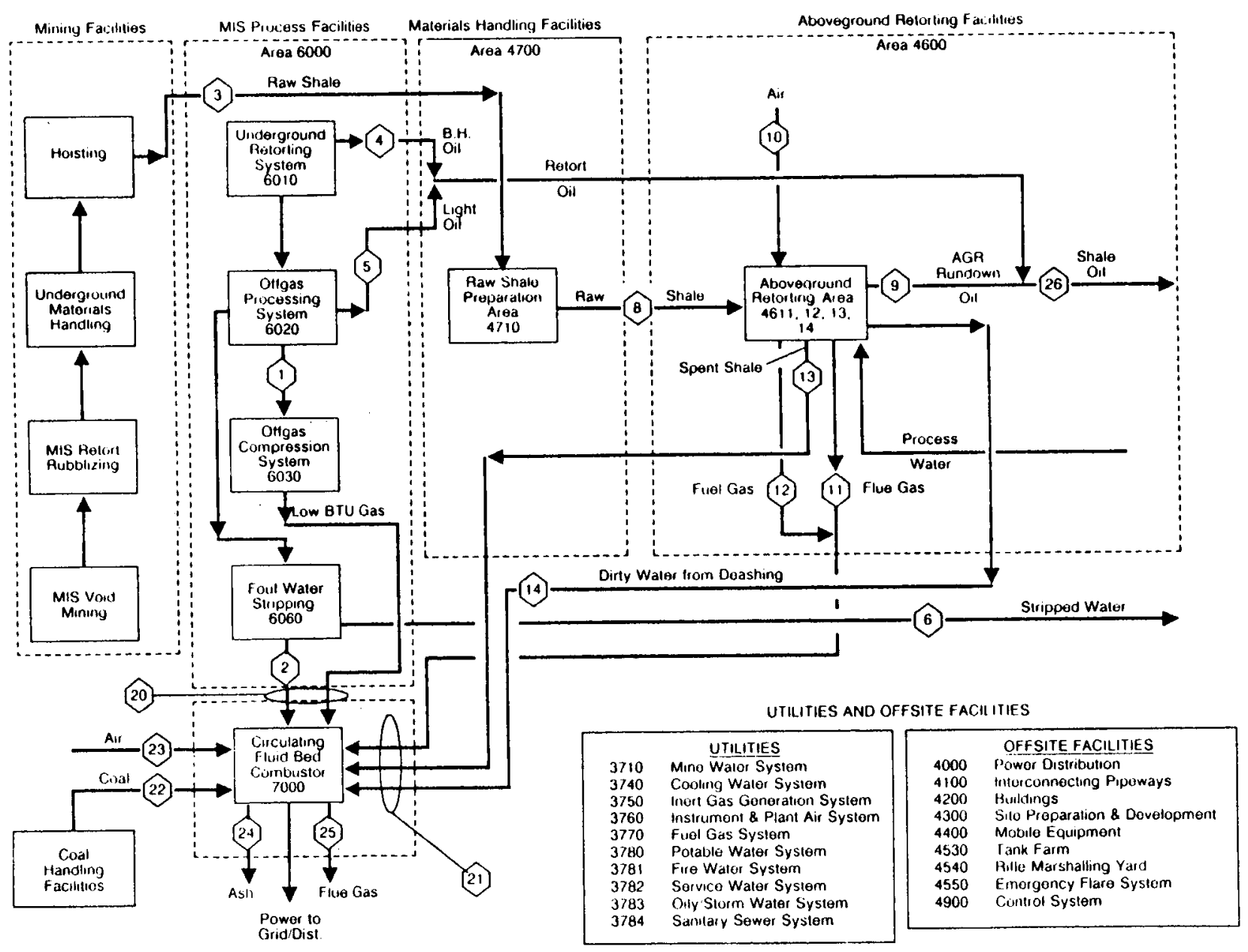




\section{Figure 1-8}

\section{BLOCK FLOW DIAGRAM \\ PHLOT SCALE PLANT \\ CASE 3}

Raw Shale from Stockpile

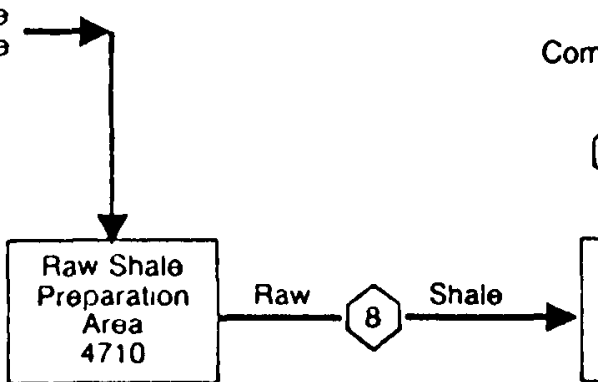

Combustion
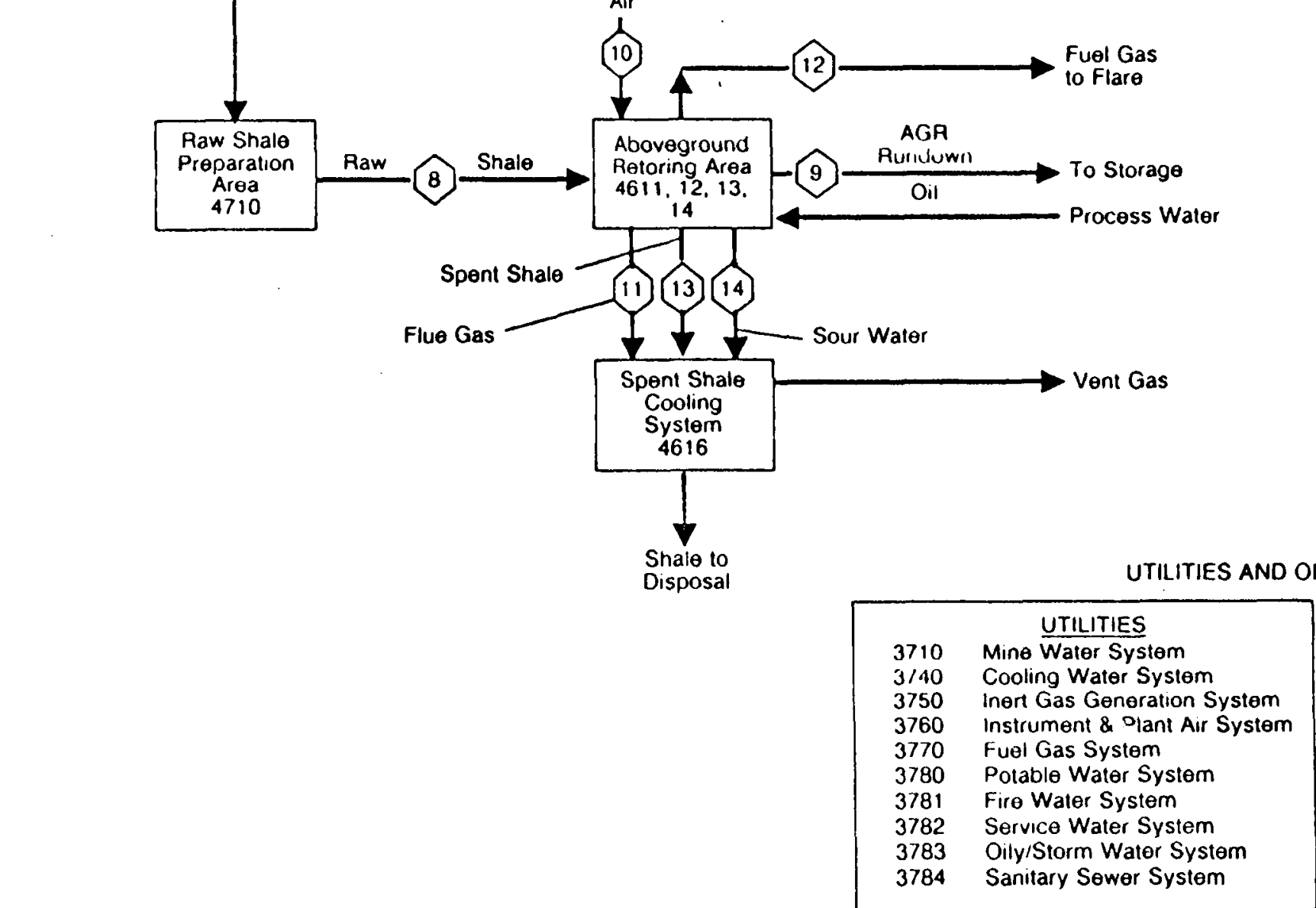

\begin{tabular}{|ll|}
\hline & OFFSITE FACILITIES \\
4000 & Power Distribution \\
4100 & Interconnecting Pipeways \\
4200 & Buildings \\
4300 & Site Preparation \& Development \\
4400 & Mobile Equipment \\
4530 & Tank Farm \\
4540 & Rifle Marshalling Yard \\
4550 & Emergency Flare System \\
4900 & Control System \\
\hline
\end{tabular}


Figure 1-9

HRS RETORT ASSEMBLY

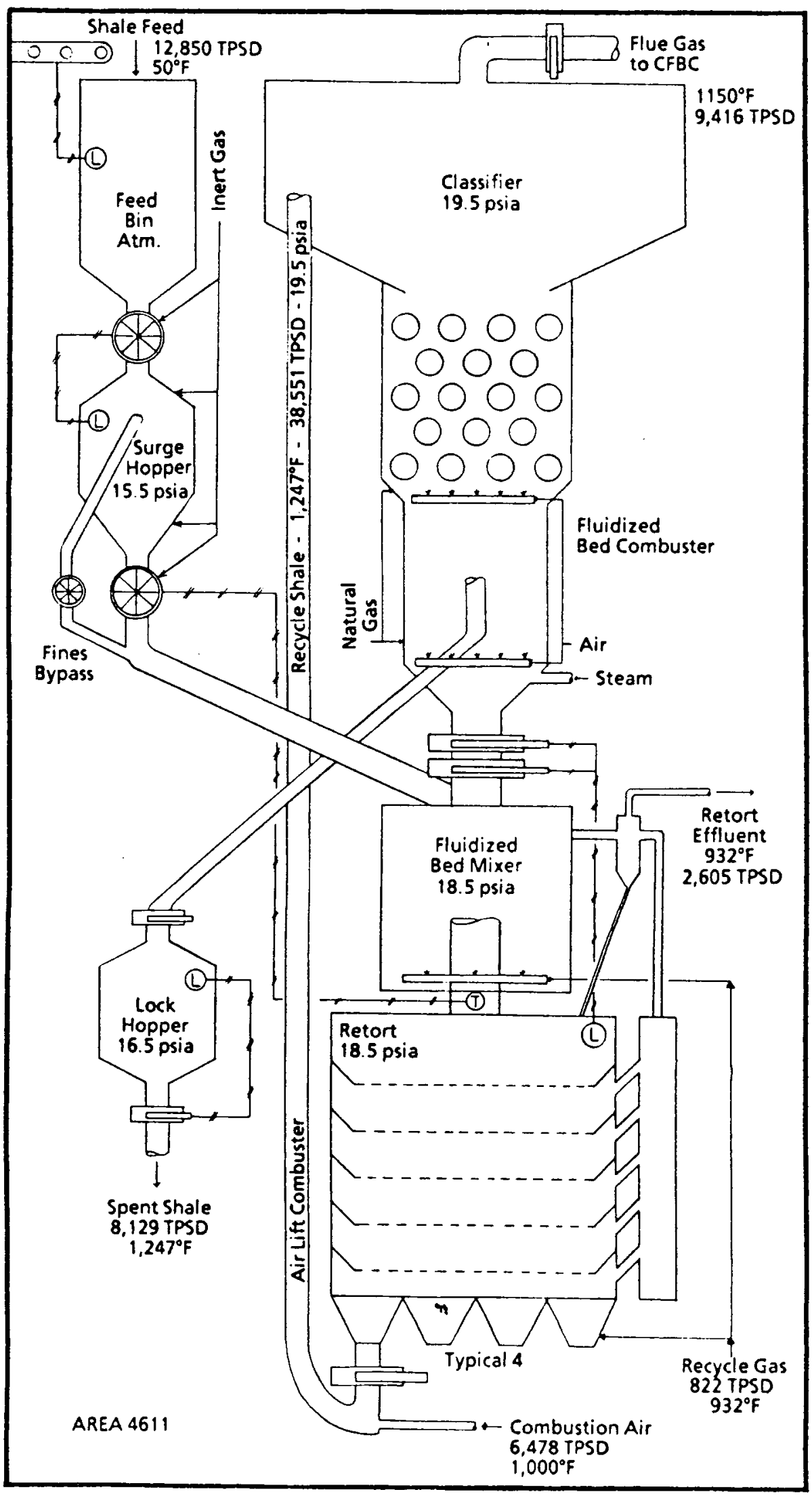


Figure 1-10

HRS RETORT GAS PROCESSING

FLOW DIAGRAM

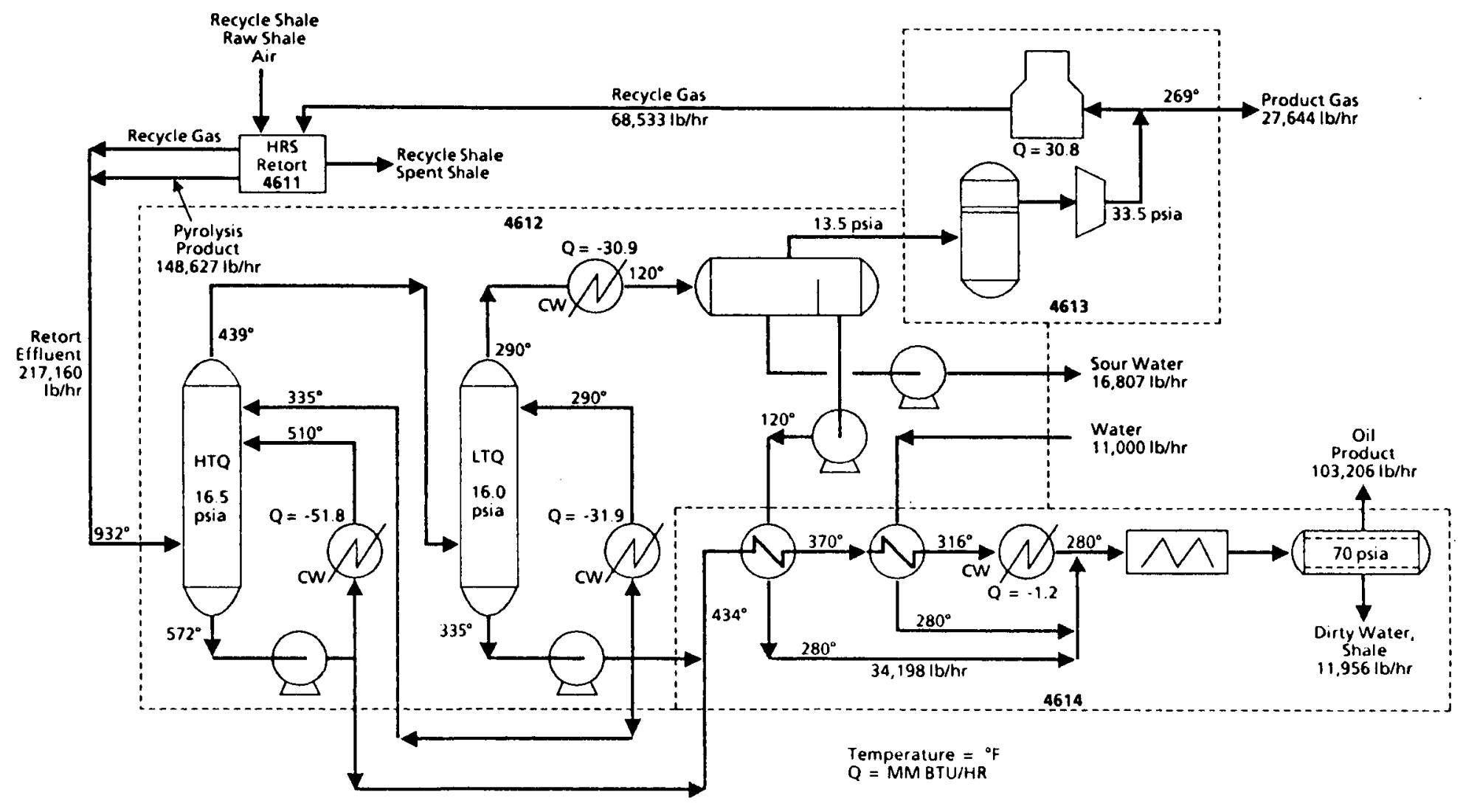


PNEUMATIC TRANSPORT AND COOLING SYSTEM - CASE 3

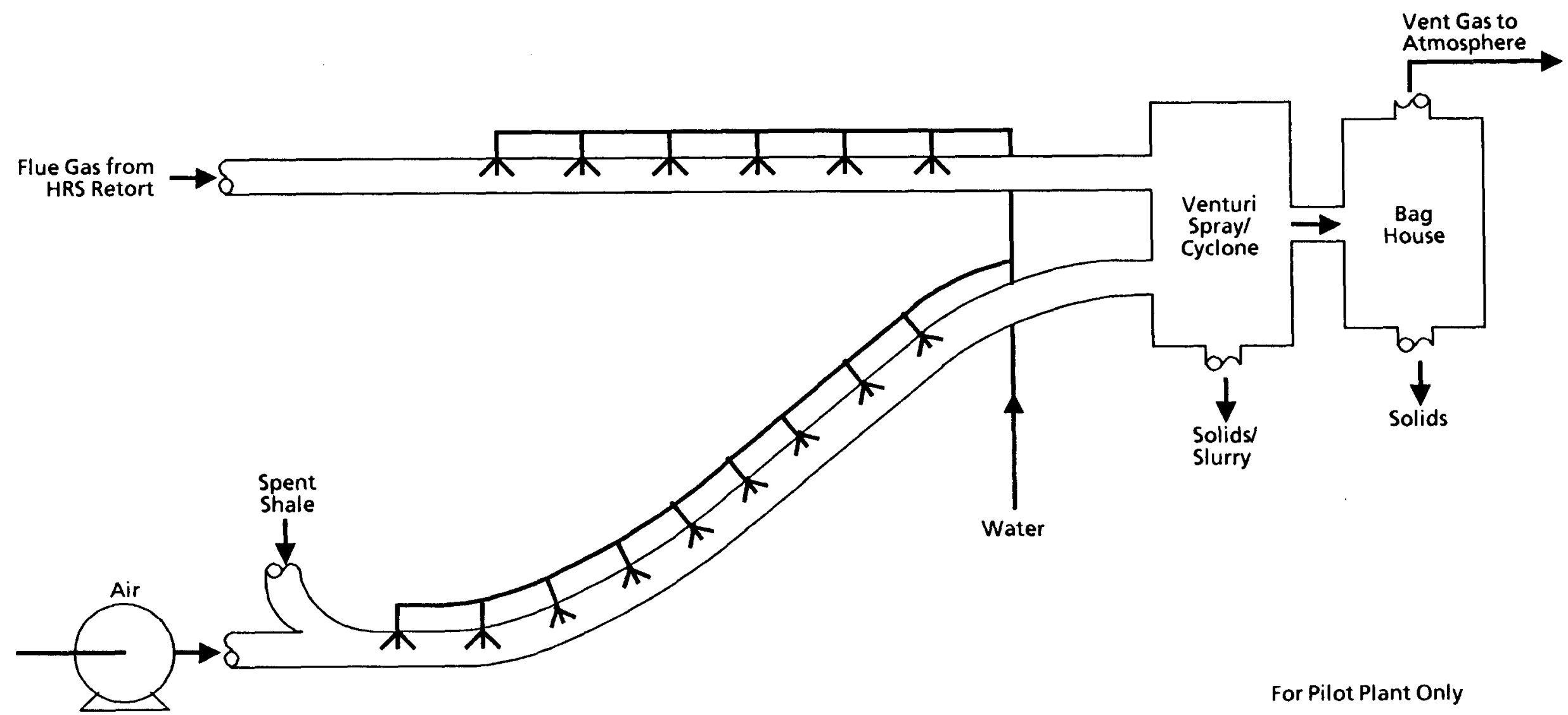


Figure 1.12

MIS MINE ISOMETRIC

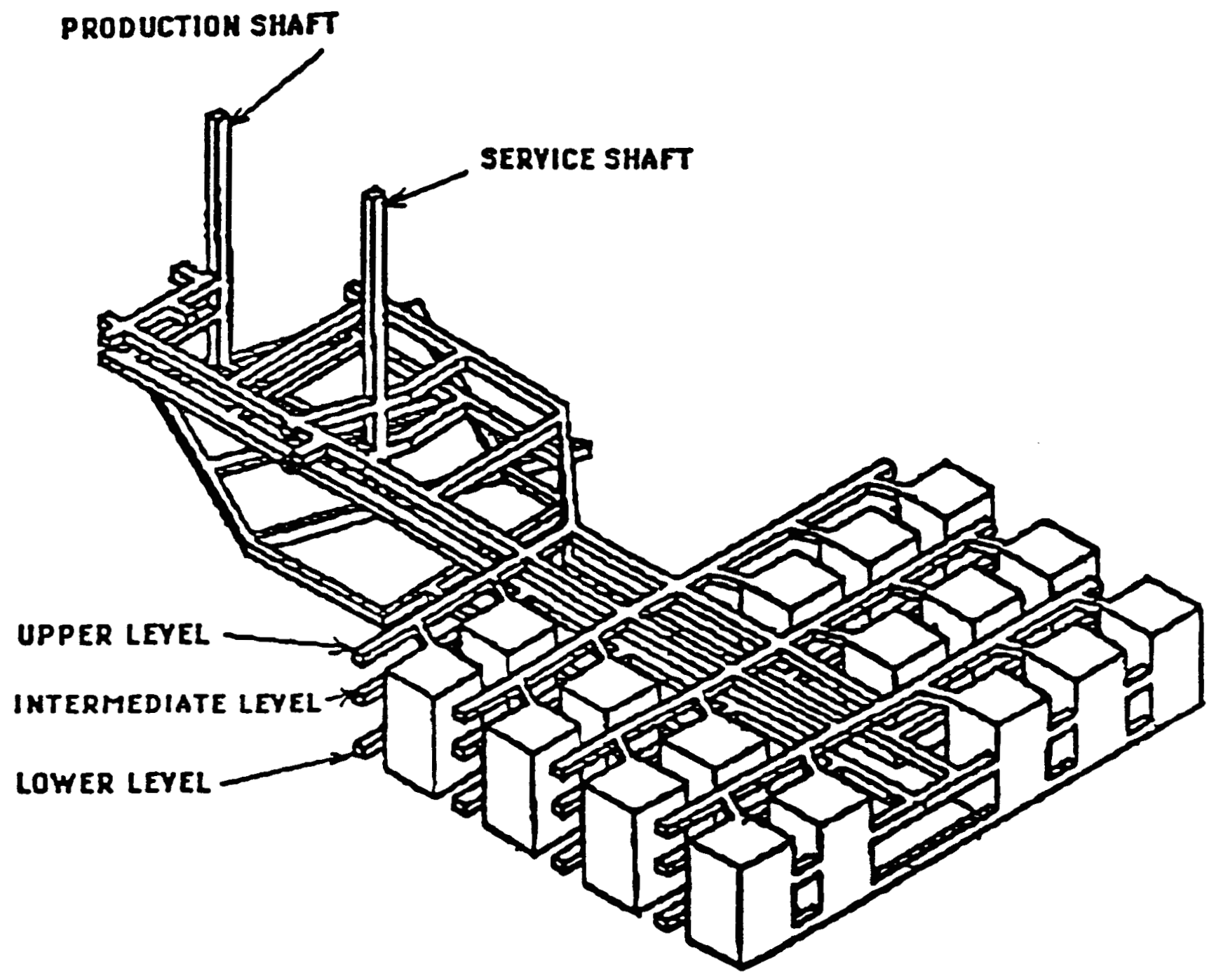




\section{INTRODUCTION}

This conceptual design study report presents technical data, costs and economic analyses of plants producing shale oil using Occidental Oil Shale, Inc.'s Modified-In-Situ (MIS) retorting technology, and a Hot-Recycled-Solids (HRS) retort developed by Lawrence Livermore National Laboratory (LLNL). A Circulating Fluidized Bed Combustor (CFBC) is used for the clean-up of effluent gas streams as well as for power generation.

Four cases have been examined in this study based on a site located on federal lease C-b, comprising a 5,094 acre tract of land in Rio Blanco County, Colorado.

The cases are as follows:

Case 1 is the Commercial size facility which involves mining facilities, MIS processing, materials handling, HRS above ground retorting, CFBC, oil upgrading and a syncrude pipeline. This process is sized with 22 simultaneously operating MIS retorts and four CFBC's. The Above Ground retort processing facility is designed for a throughput of 12,850 tons of raw shale per day which is the production of shale from the 22 simultaneously burning retorts. The total oil production from the HRS and MIS processes is 24,344 BPSD and net power production is 39 megawatts.

Case 2 is the Demonstration size plant. The areas involved are MIS mining, MIS retorts, above ground retorting and the CFBC. Two MIS simultaneous retorts and one CFBC are in operation for this plant. The CFBC used is sized to be one of the four required for the Commercial case. This combustor is larger than will be required for the Demonstration plant, and supplemental fuel (coal) will be required to maintain the flame stability. The increased fuel consumption will require additional handling and transportation costs, but will also reduce the capital cost required in the Commercial size facility. The CFBC can serve as one of the four combustors needed in the Commercial size plant. The raw shale throughput to the Above Ground Retort will be 1,000 tons/day. This case will produce 25 megawatts of power. The use of coal may qualify the plant for benefits under the government's Clean Coal Technology program.

Case $2 \mathrm{~A}$ is also a Demonstration size plant. The difference between this case and Case 2 is the size of the CFBC. The combustor is sized to optimally handle the effluents from the above and below ground retorts with a minimum of supplemental fuel. This reduced size CFBC will reduce the capital investment for the 
Demonstration plant, but it is smaller than desired for the Commercial size facility. Case $2 \mathrm{~A}$ will produce 4 megawatts of power.

Case 3 is the Pilot size plant. The objective of this size plant is to optimize the process design and operating conditions for the HRS retort. The throughput is 100 tons/day of raw shale. The only facilities involved are the materials handling and the above ground retorting system. There will not be any mining involved as the shale is mined and stockpiled, ready for crushing and loading into the retort.

This study report consists of the following sections in addition to the Executive Summary.

The DESIGN BASIS section summarizes the bases used in the design of the various plant units. In addition, the key characteistics and capacities of the various units are described.

The COSTS section presents capital and operating costs for all four cases. It describes the basis and methodology used to estimate capital costs, and the costs associated with operation and maintenance of the facilities.

The SCHEDULE section contains project schedules for Cases 1 , $2 / 2 \mathrm{~A}$ and 3 . There is also a schedule for a Pre-commercialization plan, which combines the Pilot and Demonstration plants into an integrated schedule.

The ECONOMIC ANALYSIS section summarizes the economics of producing shale oil and power for these cases. The shale oil prices to produce a range of internal rates of return (IRR) on equity were calculated for Case 1.

The PROJECT DESCRIPTION section describes the sequence and operation of the various processing units within the plant. Included in this section are block flow diagrams, material/energy balances, utility balances, and catalyst/chemical consumptions.

The TECHNICAL FEASIBILITY section discusses the design reliability of the various process units.

The APPENDICES include backup information referred to under Costs and Project Description. 


\section{DESIGN BASIS}

The key design parameters for the four cases included in this report are summarized in Table 3-1.

The following major processing units are included in the various production facilities.

\begin{tabular}{lll}
$\begin{array}{l}\text { Area } \\
\text { Unit }\end{array}$ & \multicolumn{1}{c}{ Major Plants } & \multicolumn{1}{c}{ Case No. } \\
-- & MIS Retort Development and Mining & $1,2, \& 2 \mathrm{~A}$ \\
6000 & MIS Retorts and Processing Facilities & $1,2, \& 2 \mathrm{~A}$ \\
4700 & Mined Shale Handling/Processing & All \\
7000 & CFBC/Power Generation & $1,2, \& 2 \mathrm{~A}$ \\
4600 & Above Ground Retort Facilities (AGR) & All \\
5000 & Oil Upgrading Facilities (OUG) & 1 \\
4560 & Syncrude Pipeline & 1 \\
3700 & Utilities/Offsites & All
\end{tabular}

The design basis used for the major process units are detailed on the following pages.

\section{CASE 1 - COMMERCIAL PLANT}

As noted above, Case 1 incorporates all the processing units listed. A block flow diagram of the commercial size plant is presented in Figure 3-1.

MIS Retort Development and Mining

While the MIS section envisions 22 retorts burning at any given time, the following description gives details on the development and mining of a single retort.

Mined cross section (sq ft) $\quad 165 \times 165$

Mined height (ft) 270 
Mined void (\%)

Rubblized cross section (sq ft)

Rubblized height (ft)

Rubblized plenum height (ft)

Rubblized void (\%)

Retort volume (cu ft)

Plenum volume (cu $\mathrm{ft}$ )

Rubblized void volume (cu ft)

Rubble rock volume (cu ft)

Average shale rock density (lbs/cu

Rubblized rock (tons)

Rubblized Fischer Assay (GPT)

Oil in place rubblized (Bbl)

MIS tons mined, with development, per retort (tons)

MIS tons mined, void only, per retort (tons)

Mined grade (GPT)

\section{Production Parameters}

Length of work shift (collar to collar)

Mine operating shifts

Mine production days

Time between retort ignitions

MIS tons required to be mined

MIS tons per mine shift

Total available operating hours

Productive operating hours
23.0

$160.1 \times 160.1$

260

10.0

18.5

$7,242,544$

272,250

$1,391,500$

$5,579,860$

137.5

384,700

27.0

247,307

168,000

111,500

27.0

10 hours

2 shifts per day, 12 shifts per week (1 shift per day on weekends), 3 crews in rotation working 4 shifts per week each

357 days per year

(607 shifts per year)

14 days

$4,620,000$ per year $(168,000$ per each of 27.5 retorts, including development)

7,650 tons per shift

8 hours per shift (after deducting travel, lunch and other interruptions)

7.6 per shift (efficiency adjusted for 2 shifts per day) 
MIS Retorts and Processing Facilities

MIS Retort

Retort Technology

Steady State Stream Factor

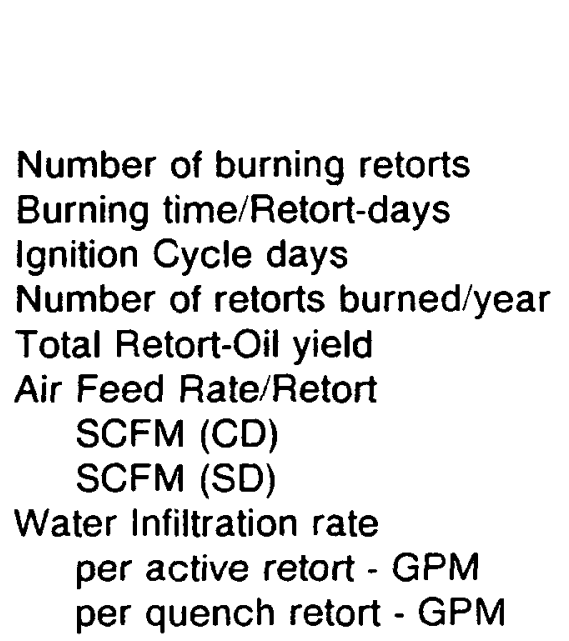

Product Streams

Total MIS Retort Off-gas MMSCFD, wet

Total Bulkhead Oil BPD

Bulkhead Oil Used as Fuel BPD

Bulkhead Oil in Water (lost) BPD

Net Bulkhead Oil Recovered BPD

Aerosol Oil (with Off-gas) BPD

Light oil in Off-gas

BPD

Occidental Oil Shale, Inc. $95 \%$

Annual

Average

22

22

$292 \quad 292$

13.3

27.5

$77 \%$

126,324

132,968

25

25

25

25

900

948

9,586

10,090

55

58

286

301

, 731

Design

13.3

27.5

$77 \%$

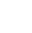

.


Annual

Average

Design

Retort Water

Total produced in active retort

GPM

400

440

Quench Water

Total consumed in spent retort

GPM

400

440

Product Conditions

Total MIS Retort Off-gas (at surface inlet to Off-gas processing)

Press., psia

Temp., ${ }^{\circ} \mathrm{F}$

Bulkhead Oil (at surface)

Temp., ${ }^{\circ} \mathrm{F}$

Retort Water (at surface)

Temp., ${ }^{\circ} \mathrm{F}$

MIS Retort Off-gas

Total Off-gas Composition

(vol \% dry)

$\mathrm{H}_{2}$
$\mathrm{~N}_{2}+\mathrm{Ar}$
$\mathrm{O}_{2}+$
$\mathrm{CO}$
$\mathrm{CO}_{2}$
$\mathrm{CH}_{4}$
$\mathrm{C}_{2} \mathrm{H}_{4}$
$\mathrm{C}_{2} \mathrm{H}_{6}$
$\mathrm{C}_{3} \mathrm{H}_{6}$
$\mathrm{C}_{3} \mathrm{H}_{8}$
$\mathrm{C}_{4}$ 's
$\mathrm{C}_{5}$ 's
$\mathrm{C}_{6}+$
$\mathrm{NH}_{3}$
$\mathrm{H}_{2} \mathrm{~S}$
$\mathrm{COS} \mathrm{S}$
$\mathrm{CS}_{2}$
$\mathrm{CH}_{3} \mathrm{SH}$
$\mathrm{C}_{2} \mathrm{H}_{5} \mathrm{SH}$
Water content, vol \%
Aerosol Oil API Gravity

8.5

156

8.5

156

140

140

140

140
8.17

55.35

0.14

2.87

29.73

1.20

0.09

0.28

0.09

0.11

0.09

0.04

0.40

0.58

0.77

20 ppm

36 ppm

71 ppm

$71 \mathrm{ppm}$

37.8

39.7
8.58

54.46

0.10

2.96

30.06

1.28

0.08

0.29

0.09

0.11

0.09

0.04

0.45

0.62

0.77

20 ppm

36 ppm

71 ppm

71 ppm

39.3

39.7 


\section{Off-gas Processing}

Off-gas Processing Technology

Steady State Stream Factor

Feed Streams

MIS Retort Off-gas

MMSCFD, wet

Aerosol Oil

$B P D$

Stripped Water, GPM

Feed Condition

MIS Retort OHt-gas, Press., psia

MIS Retort Off-gas, Temp., ${ }^{\circ} \mathrm{F}$

Stripped Water, Temp., ${ }^{\circ} \mathrm{F}$

Feed Properties

Product Streams

Low-Btu Off-gas

MMSCFD

Foul Water, GPM

Aerosol Oil (in foul water) BPD

Recovered Light Oil

BPD

Total Light Oil Product BPD

Light Oil Recovery, \%
General Refinery Type Hydrocarbon Processing Technology

$95 \%$

Annual

Average

Design

540.3

568.7

1,930

2,040

2,750

8.5

156

82

Same as MIS Retort Off-gas

540

569

3,828

4,400

1,930

2,040

2,091

2,200

4,021

4,240

75

75 
Product Conditions

Annual

Average

Design

Low-Btu Off-gas, Press., psia

6.95

Low-Btu Off-gas, Temp., ${ }^{\circ} \mathrm{F}$

50

Foul Water, Temp., ${ }^{\circ} \mathrm{F}$

120

Recovered Light Oil, Temp., ${ }^{\circ} \mathrm{F}$

110

\section{Product Properties}

Low-Btu Off-gas Composition

(Vol \% dry)

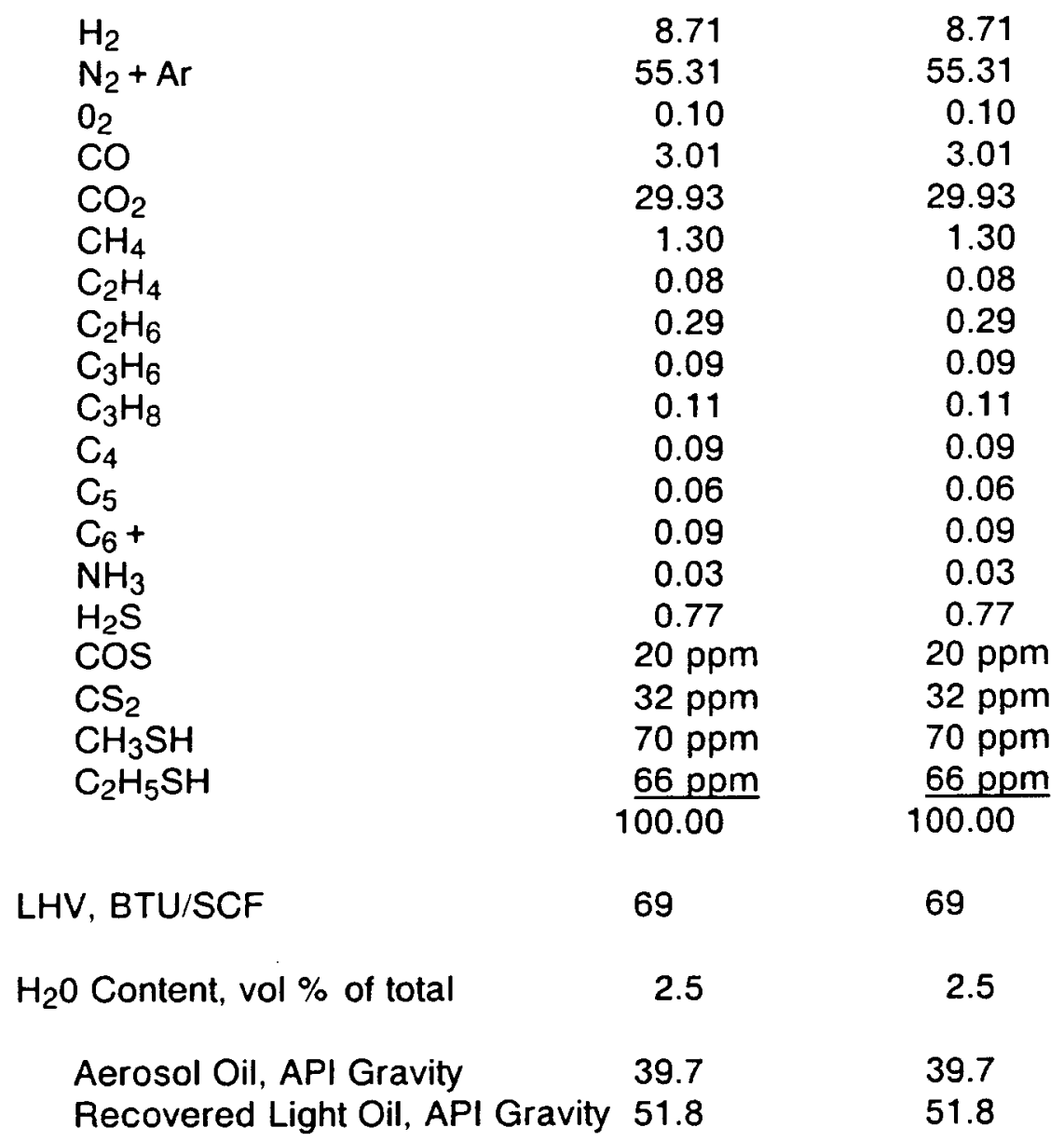


Off-gas Compression

Feed Stream

\begin{tabular}{lc}
$\begin{array}{l}\text { Annual } \\
\text { Average }\end{array}$ & Design \\
\hline & \\
540 & 569 \\
7.1 & 6.95 \\
50 & 50
\end{tabular}

Product Requirement

Pressure - PSIA

$27 \quad 27$

Temp. - ${ }^{\circ} \mathrm{F}$

(isentropic Temperature)

Foul Water Stripping

Feed Stream

$\begin{array}{lll}\text { Foul water, GPM } & 3,828 & 4,400\end{array}$

Composition and Conditions, ppmw

$\begin{array}{lrr}\mathrm{CO}_{2} & 7,481 & 7,481 \\ \mathrm{NH}_{3} & 3,018 & 3,018 \\ \mathrm{H}_{2} \mathrm{~S} & 136 & 136 \\ \text { Temperature, }{ }^{\circ} \mathrm{F} & 145 & 120 \\ & & \\ & & 2,040\end{array}$

Products

Stripped water, GPM

3,795

4,360

Composition, ppmw

$\mathrm{NH}_{3}$

$\mathrm{H}_{2} \mathrm{~S}$

$50 \quad 50$

$\mathrm{CO}_{2}$

TR

8
TR

Sour Gas MMSCFD

Composition, vol \%

132.1

139.0

$\mathrm{CO}_{2}$

$\mathrm{NH}_{3}$

5.41

5.41

$\mathrm{H}_{2} \mathrm{~S}$

5.72

5.72

0.13

0.13

$\mathrm{H}_{2} \mathrm{O}$

88.74

88.74

Total

100.00

100.00 
Annual

Average

Design

Aerosol Oil

BPD

API Gravity

1,930

39.7

2,040

39.7

Stripping Efficiencies \%

$\mathrm{CO}_{2}$

100.0

100.0

$\mathrm{NH}_{3}$

98.6

98.6

$\mathrm{H}_{2} \mathrm{~S}$

95.4

95.4

Mined Shale Handling and Processing

\section{Mining}

Underground Primary Crusher Material

Hoist Schedule

Tons Hoisted per hour

(Normal Operating)

Tons Hoisted per hour

(Design)

Mine Production (days/year)

Bulk Density of Hoisted Rock

Fines Present in Hoisted Rock

Rock Surface Moisture

Local Coarse Shale Stockpile

Normal Feed Rate

Design Feed Rate

Normal Reclaim Rate

Design Reclaim Rate

Live Capacity
-8 " nominal, $20 " \times 12 " \times 8$ "

max. lump size

$18.5 \mathrm{hrs} / \mathrm{stream}$ day

$850 \mathrm{TPSH}$

2000 TPSH

357 days

$80 \mathrm{lb} / \mathrm{cu} \mathrm{ft}$

$5 \%$

$2 \%$

850 TPSH

2000 TPSH

540 TPSH

650 TPSH

37,000 tons ( 3 days) 
Dead Capacity

Primary Crushing

Normal Feed Rate

Design Feed Rate

Feed Size

Product Size

Type of Crusher

Redundancy

Secondary Crushing

Normal feed rate

Design feed rate

Feed size

Product Size

Type of Crusher

Redundancy

Surge Bin

Purpose

Capacity

Dust Control

Headframe to Lowering Well

Reclaim from Storage Pile
117,700 tons (9 days)

540 TPSH

$650 \mathrm{TPSH}$

$+2 " x-10 "$

$-2 "$

Double Roll

$100 \%$ spare

540 TPSH

650 TPSH

$-2^{\prime \prime}$

$-1 / 4^{\prime \prime} \times 0$

Single roll

$100 \%$ spare

2-1/2 $\mathrm{hr}$ storage for final feed to the HRS retort and the CFBC during interrupted supply from crushing plant

1350 tons

Water Sprays

Baghouses 
Weather Protection

Crushers

Fine Ore Surge Bin

Elevated Transfer House

Conveyors

Control Room and Laboratory
Closed building (maintained above freezing)

Closed building (maintained above freezing)

Roof with open sides

Covered

Closed building, heated $\left(68^{\circ} \mathrm{F}\right)$ and pressurized

CFBC/Power Generation

The design basis for the steam/power plant incorporates Circulating Fluidized Bed Combustor technology.

Feed Streams

MIS Off-gas

MIS Sour Gas

HRS Flue Gas

HRS Fuel Gas

HRS Spent Shale

HRS Dirty Water

Coal

$$
\begin{gathered}
1,008 \text { TPSH } \\
74 \text { TPSH } \\
393 \text { TPSH } \\
11 \text { TPSH } \\
338 \text { TPSH } \\
5 \text { TPSH } \\
\text { 43.5 TPSH }
\end{gathered}
$$

Product Streams

$$
\begin{aligned}
& \text { Electric Power } \\
& 600 \text { PSI Steam } \\
& 150 \text { PSI Steam }
\end{aligned}
$$

114 Megawatts

278 TPSH

$130 \mathrm{TPSH}$

The compositions of the gas streams are shown on Table 7-1. 
The coal analysis is (ultimate analysis, as received):

Coal Analysis

$\begin{array}{lc}\text { Moisture } & 10.5 \% \\ \text { Carbon } & 58.44 \% \\ \text { Hydrogen } & 4.14 \% \\ \text { Nitrogen } & 1.17 \% \\ \text { Chlorine } & 0.02 \% \\ \text { Sulfur } & \\ \quad \text { Pyretic } & 0.04 \% \\ \quad \text { Organic } & 0.46 \% \\ \quad \text { Sulfate } & 0.0 \% \\ \text { Ash } & 16.0 \% \\ \text { Oxygen } & 9.23 \% \\ \text { Net Heating Value (LHV) } & 10,300 \mathrm{Btu} / \mathrm{lb}\end{array}$

Above Ground Retorting Facilities

Retort Technology

Number of Retorts

Steady-state Stream Factor

Raw Shale Feed Rate

Shale Properties

Grade

Size Requirements

Product Recovered

Recovery (crude oil)

Deashed Shale Oil

Spent shale

AGR Make Gas

Sour Water
Lawrence Livermore National Laboratory HRS

One

$95 \%$

12,207 TPCD

12,850 TPSD

27 GPT

$-1 / 4^{4}$

$94 \%$

$7,534 \mathrm{BPCD}$

7,930 BPSD

10,164 TPCD

10,699 TPSD

332 TPSD

70 TPSD

公 Revr, $2-5-90$ 
Oil Upgrading Facilities

Hydrotreating Technology

Hydrogen Technology

Feed for $\mathrm{H}_{2}$ make

Sulfur Recovery Technology

Ammonia Recovery Technology

Oilfeed

BPCD

BPSD

API gravity

Viscosity - CS@100\% F

Pour point - ${ }^{\circ} \mathrm{F}$

Nitrogen Content

Sulfur Content

Arsenic Content - wppm

Treated Product

BPCD

BPSD

API gravity

Viscosity - CS@ $100^{\circ} \mathrm{F}$

Nitrogen Content - wppm

Sulfur Content - wppm

Arsenic Content - wppm

By-products Recovered

Sulfur - TPCD

Ammonia - TPCD

[ ] denotes estimated value;
Union Oil

Natural Gas Reforming with

Purification

Natural Gas

Claus w/SCOT Tailgas Unit

Phosam-W
20,799

21,894

28.89

[12]

[70]

[1.5]

[1.2]

[50]
$[23,125]$

[24,344]

[42]

$[<12]$

$\{100 \max \}$

$\{<5\}$

$\{<0.5\}$

25.5

76.0

\{\} denotes specification 
Syncrude Pipeline

\section{Capacity}

BPCD

GPM

Total Length - miles

No. Pump Stations
23,000

700

46

One at Plant Site

Utilities/Offsites

The utility systems that are included in the Case 1, Commercial Plant are:

- Mine Water System

- Cooling Water System

- Inert Gas Generation System

- Instrument and Plant Air System

- Fuel Gas System

- Potable Water System

- Fire Water System

- Service Water System

- Oily/Storm Water System

- Sanitary Sewer System

The offsite facilities that are included in the Case 1, Commercial Plant are:

- Power Distribution

- Interconnecting Pipeways

- Buildings

- Site Preparation and Development

- Mobile Equipment

- Tank Farm

- Rifle Marshalling Yard

- Emergency Flare System

- Control System

CASE 2 and 2A - Demonstration Plant

As noted at the beginning of this section, Case 2/2A incorporates all of the processing units except the oil upgrade facilities and the syncrude pipeline. A block flow diagram of the demonstration size plant is presented in Figure 3-2. 
MIS Retort Development and Mining

Mined cross section ( $\mathrm{ft}^{2}$ )

Mined height (ft)

Mined void (\%)

Rubblized cross section ( $\mathrm{ft}^{2}$ )

Rubblized height (ft)

Rubblized plenum height (ft)

Rubblized void (\%)

Retort volume ( $\left.\mathrm{ft}^{3}\right)$

Plenum volume $\left(\mathrm{ft}^{3}\right)$

Rubblized void volume (ft3)

Rubble rock volume ( $\left.t^{3}\right)$

Average shale rock density (lbs/cu ft)

Rubblized rock (tons)

Rubblized Fischer Assay (GPT)

Oil in place rubblized (Bbl)

MIS tons mined, with development, per retort (tons)

MIS tons mined, void only, per retort (tons)

Mined grade (GPT)

\section{Production Parameters}

Length of work shift

(collar to collar)

Mine operating shifts

Mine production days

Time between retort ignitions

MIS tons required to be mined

MIS tons per mine shift
$165 \times 165$

278

23.0

$160.1 \times 160.1$

268

10.0

18.5

$7,242,544$

272,250

$1,391,500$

$5,579,860$

137.5

384,700

27.0

247,307

168,000

111,500

27.0

10 hours

2 shifts per day, 12 shifts per week (1 shift per day on weekends), 3 crews in rotation working 4 shifts per week each

357 days per year (607 shifts per year)

146 days

420,000 per year $(168,000$ per each of 2.5 retorts, including development)

700 tons per shift 
Total available operating hours

Productive operating hours
8 hours per shift (after deducting travel, lunch, and other interruptions)

7.6 per shift (efficiency adjusted for 2 shifts per day)

MIS Retorts and Processing Facilities

Retort Technology

Steady State Stream Factor
Occidental Oil Shale, Inc. $95 \%$

Annual

Average

Design

Number of burning retorts

Burning time/Retort-days

Ignition Cycle days

Number of retorts burned/year

Total Retort Oil Yield

Air Feed Rate/Retort

SCFM (CD)

SCFM (SD)

Water Infiltration rate

per active retort - GPM

per quench retort - GPM

Product Streams

Total MIS Retort Off-gas MMSCFD, wet

81.9

86.2

Total Bulkhead Oil BPD

871

917

Bulkhead Oil Used as Fuel BPD

5

5.3

Bulkhead Oil in Water (lost) BPD

26

27

Net Bulkhead Oil Recovered BPD
840

884 
Annual

Average

Design

Aerosol Oil (with Off-gas)

BPD

175

185

Light oil in Off-gas

BPD

253

266

Retort Water

Total produced in active retort

GPM

36.6

40.1

Quench Water

Total consumed in spent retort GPM

36.6

40.1

\section{Product Conditions}

Total MIS Retort Off-gas (at surface inlet to Off-gas processing)

$$
\begin{aligned}
& \text { Press., psia } \\
& \text { Temp., }{ }^{\circ} \mathrm{F}
\end{aligned}
$$

156

8.5

156

Bulkhead Oil (at surface)

Temp., ${ }^{\circ} \mathrm{F}$

140

140

Retort Water (at surface)

$$
\text { Temp., }{ }^{\circ} \mathrm{F}
$$

140

140

\section{MIS Retort Off-gas}

Total Off-gas Composition

(vol \% dry)

$\mathrm{H}_{2}$

$\mathrm{N}_{2}+\mathrm{Ar}$

$\mathrm{O}_{2}+$

$\mathrm{CO}$

$\mathrm{CO}_{2}$

$\mathrm{CH}_{4}$

$\mathrm{C}_{2} \mathrm{H}_{4}$

$\mathrm{C}_{2} \mathrm{H}_{6}$

$\mathrm{C}_{3} \mathrm{H}_{6}$

$\mathrm{C}_{3} \mathrm{H}_{8}$

$\mathrm{C}_{4}$ 's

$\mathrm{C}_{5}$ 's

$\mathrm{C}_{6}+$

$\mathrm{NH}_{3}$
8.17

55.35

0.14

2.87

29.73

1.20

0.09

0.28

0.09

0.11

0.09

0.04

0.40

0.58
8.58

54.46

0.10

2.96

30.06

1.28

0.08

0.29

0.09

0.11

0.09

0.04

0.45

0.62 


\begin{tabular}{lll} 
& $\begin{array}{l}\text { Annual } \\
\text { Average }\end{array}$ & Design \\
\cline { 2 - 2 } & 0.77 & 0.77 \\
$\mathrm{H}_{2} \mathrm{~S}$ & $20 \mathrm{ppm}$ & \\
$\mathrm{COS} 20 \mathrm{ppm}$ & $36 \mathrm{ppm}$ & \\
$\mathrm{CS}_{2} 36 \mathrm{ppm}$ & $71 \mathrm{ppm}$ & $71 \mathrm{ppm}$ \\
$\mathrm{CH}_{3} \mathrm{SH}$ & $71 \mathrm{ppm}$ & $71 \mathrm{ppm}$ \\
$\mathrm{C}_{2} \mathrm{H}_{5} \mathrm{SH}$ & 37.8 & 39.3 \\
Water content, vol \% & 39.7 & 39.7 \\
Aerosol Oil API Gravity & &
\end{tabular}

\section{Off-gas Processing}

Off-gas Processing

General Refinery Type Hydrocarbon Processing

Steady State Stream Factor Technology $95 \%$

Feed Streams

MIS Retort Off-gas MMSCFD, wet

Aerosol Oil BPD

Stripped Water, GPM

Feed Condition

MIS Retort Off-gas, Press., psia

MIS Retort Off-gas, Temp., ${ }^{\circ} \mathrm{F}$

Stripped Water, Temp., ${ }^{\circ} \mathrm{F}$

Feed Properties Same as MIS Retort Off-gas

\section{Product Streams}

\section{Low-Btu Off-gas} MMSCFD

49.1

Foul Water, GPM 
Annual

Average

175

185

Recovered Light Oil

BPD

191

200

Total Light Oil Product BPD

366

385

Light Oil Recovery, \%

75

Product Conditions

Low-Btu Off-gas, Press., psia

Low-Btu Off-gas, Temp., ${ }^{\circ} \mathrm{F}$

50

Foul Water, Temp., ${ }^{\circ} \mathrm{F}$

120

Recovered Light Oil, Temp., ${ }^{\circ} \mathrm{F}$

110

Product Properties

Low-Btu Off-gas Composition

(Vol \% dry)

$\mathrm{H}_{2}$
$\mathrm{~N}_{2}+\mathrm{Ar}$
$\mathrm{O}_{2}$
$\mathrm{CO}$
$\mathrm{CO}_{2}$
$\mathrm{CH}_{4}$
$\mathrm{C}_{2} \mathrm{H}_{4}$
$\mathrm{C}_{2} \mathrm{H}_{6}$
$\mathrm{C}_{3} \mathrm{H}_{6}$
$\mathrm{C}_{3} \mathrm{H}_{8}$
$\mathrm{C}_{4}$
$\mathrm{C}_{5}$
$\mathrm{C}_{6}+$
$\mathrm{NH}_{3}$
$\mathrm{H}_{2} \mathrm{~S}$

8.71

8.71

55.31

0.10

55.31

0.10

3.01

29.93

3.01

29.93

1.30

1.30

0.08

0.08

0.29

0.29

0.09

0.09

0.11

0.11

0.09

0.09

0.06

0.09

0.06

0.03

0.09

0.77

0.03

0.77 


\begin{tabular}{|c|c|c|}
\hline & $\begin{array}{l}\text { Annual } \\
\text { Average }\end{array}$ & Design \\
\hline $\begin{array}{l}\mathrm{COS} \\
\mathrm{CS}_{2} \\
\mathrm{CH}_{3} \mathrm{SH} \\
\mathrm{C}_{2} \mathrm{H}_{5} \mathrm{SH}\end{array}$ & $\begin{array}{l}20 \mathrm{ppm} \\
32 \mathrm{ppm} \\
70 \mathrm{ppm} \\
66 \mathrm{ppm} \\
100.00\end{array}$ & $\begin{array}{l}20 \mathrm{ppm} \\
32 \mathrm{ppm} \\
70 \mathrm{ppm} \\
66 \mathrm{ppm} \\
100.00\end{array}$ \\
\hline LHV, BTU/SCF & 69 & 69 \\
\hline $\mathrm{H}_{2} \mathrm{O}$ Content, vol $\%$ of total & 2.5 & 2.5 \\
\hline Aerosol Oil, API Gravity & 39.7 & 39.7 \\
\hline Recovered Light Oil, API Gravity & 51.8 & 51.8 \\
\hline
\end{tabular}

\section{Off-gas Compression}

Feed Stream

Flow

MMSCFD

$\begin{array}{ll}49.1 & 51.7\end{array}$

Pressure - PSIA

$\begin{array}{ll}7.1 & 6.95\end{array}$

Temp. - ${ }^{\circ} \mathrm{F}$

$50 \quad 50$

Product Requirement

$\begin{array}{llc}\text { Pressure - PSIA } & 27 & 27 \\ \text { Temp. }-{ }^{\circ} \mathrm{F} & \text { (isentropic Temperature) }\end{array}$

Foul Water Stripping

Feed Stream

$\begin{array}{lll}\text { Foul water, GPM } & 348 & 400\end{array}$

Composition and Conditions, ppmw

$\begin{array}{lrr}\mathrm{CO}_{2} & 7,481 & 7,481 \\ \mathrm{NH}_{3} & 3,018 & 3,018 \\ \mathrm{H}_{2} \mathrm{~S} & 136 & 136 \\ \text { Temperature, }^{\circ} \mathrm{F} & 145 & 120\end{array}$

Aerosol Oil, (in foul water) BPD $175 \quad 185$ 


\section{Products}

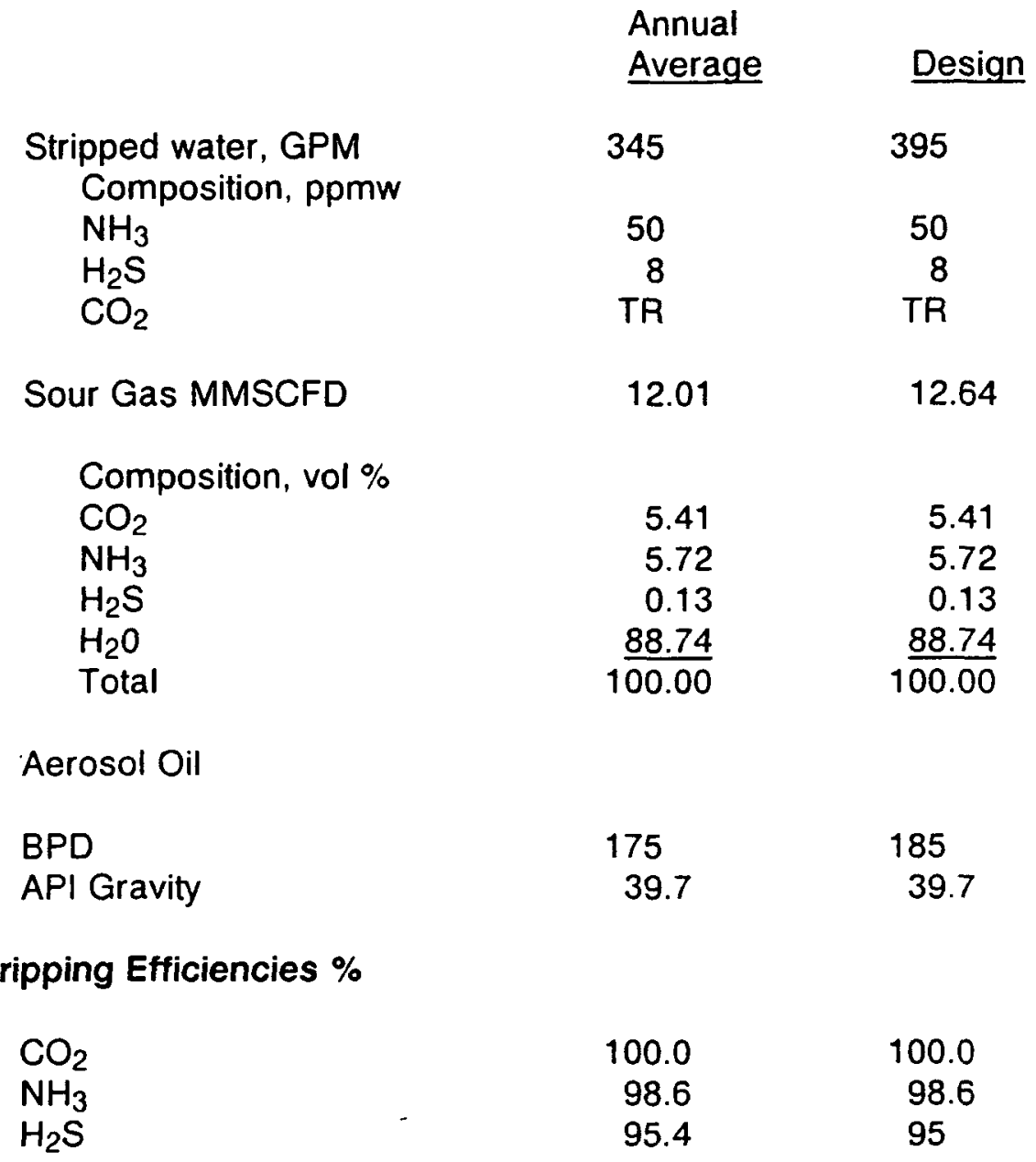

Mined Shale Handling and Processing

\section{Mining}

$\begin{array}{ll}\begin{array}{l}\text { Underground Primary Crusher } \\ \text { Material }\end{array} & \begin{array}{l}-8 " \text { nominal, 20" } \\ \text { max. lump size }\end{array} \\ \begin{array}{l}\text { Hoist Schedule } \\ \text { Tons Hoisted per hour }\end{array} & 18.5 \mathrm{hrs} / \mathrm{stream} \text { day } \\ \text { (Normal Operating) } & 80 \mathrm{TPSH} \\ \begin{array}{l}\text { Tons Hoisted per hour } \\ \text { (Design) }\end{array} & 200 \mathrm{TPSH} \\ \begin{array}{l}\text { Mine Production (days/year) } \\ \text { Bulk Density of Hoisted Rock }\end{array} & 357 \text { days } \\ \end{array}$




$\begin{array}{ll}\text { Fines Present in Hoisted Rock } & 5 \% \\ \text { Rock Surface Moisture } & 2 \% \\ \text { Local Coarse Shale Stockpile } & \\ \text { Capacity } & 243 \text { days storage (239 days } \\ \text { dead, } 4 \text { days live }\end{array}$

\section{Primary Crushing}

$\begin{array}{ll}\text { Normal Feed Rate } & 42 \text { TPSH } \\ \text { Design Feed Rate } & 50 \text { TPSH } \\ \text { Feed Size } & +2^{\prime \prime} \times-10^{\prime \prime} \\ \text { Product Size } & -2^{\prime \prime} \\ \text { Type of Crusher } & \text { Double Roll } \\ \text { Redundancy } & 100 \% \text { spare }\end{array}$


Secondary Crushing

Normal feed rate

42 TPSH

Design feed rate

50 TPSH

Feed size

$-2 "$

Product Size

$-1 / 4^{\prime \prime} \times 0$

Type of Crusher

Redundancy

Single roll

$100 \%$ spare

Surge Bin

Purpose

$3 \mathrm{hr}$ storage for final feed during interrupted supply from crushing plant

Capacity

150 tons

\section{Dust Control}

Headframe to Lowering Well

Water Sprays

Reclaim from Storage Pile to CFBC

Baghouses

Weather Protection

Crushers

Closed building (maintained above freezing)

Fine Ore Surge Bin

Closed building (maintained above freezing)

Elevated Transfer House

Roof with open sides

Conveyors

Covered

Control Room and Laboratory

Closed building, heated $\left(68^{\circ} \mathrm{F}\right)$ and pressurized 
The design basis for the steam/power plant incorporates Circulating Fluidized Bed Combustor technology.

\section{CASE 2}

Feed Streams

$$
\begin{aligned}
& \text { MIS Off-gas } \\
& \text { MIS Sour Gas } \\
& \text { HRS Flue Gas } \\
& \text { HRS Fuel Gas } \\
& \text { HRS Spent Shale } \\
& \text { HRS Dirty Water } \\
& \text { Coal } \\
& \text { Limestone }
\end{aligned}
$$$$
92 \text { TPSH }
$$$$
7 \text { TPSH }
$$$$
30 \text { TPSH }
$$$$
0.8 \mathrm{TPSH}
$$$$
26 \text { TPSH }
$$$$
0.5 \mathrm{TPSH}
$$$$
21 \mathrm{TPSH}
$$$$
5 \text { TPSH }
$$

Product Streams

Electric Power 600 PSI Steam 150 PSI Steam
31 Megawatts 23 TPSH 5.5 TPSH

\section{CASE 2A}

Feed Streams

$$
\begin{aligned}
& \text { MIS Off-gas } \\
& \text { MIS Sour Gas } \\
& \text { HRS Flue Gas } \\
& \text { HRS Fuel Gas } \\
& \text { HRS Spent Shale } \\
& \text { HRS Dirty Water } \\
& \text { Coal }
\end{aligned}
$$

$$
\begin{aligned}
& 92 \text { TPSH } \\
& 7 \text { TPSH } \\
& 30 \text { TPSH } \\
& 0.8 \text { TPSH } \\
& 26 \text { TPSH } \\
& 0.5 \text { TPSH } \\
& 4 \text { TPSH }
\end{aligned}
$$

\section{Product Streams}

$$
\begin{aligned}
& \text { Electric Power } \\
& 600 \text { PSI Steam } \\
& 150 \text { PSI Steam }
\end{aligned}
$$

10 Megawatts $23 \mathrm{TPSH}$ 5.5 TPSH

The compositions of the gas streams are shown on Table 7-2. 
The coal analysis is (ultimate analysis, as received):

\section{Coal Analysis}

$\begin{array}{lc}\text { Moisture } & 10.5 \% \\ \text { Carbon } & 58.44 \% \\ \text { Hydrogen } & 4.14 \% \\ \text { Nitrogen } & 1.17 \% \\ \text { Chlorine } & 0.02 \% \\ \text { Sulfur } & \\ \quad \text { Pyretic } & 0.04 \% \\ \text { Organic } & 0.46 \% \\ \text { Sulfate } & 0.0 \% \\ \text { Ash } & 16.0 \% \\ \text { Oxygen } & 9.23 \% \\ \text { Net Heating Value } & 10,300 \mathrm{Btu} / \mathrm{lb}\end{array}$

Above Ground Retorting Facilities

Retort Technology

Number of Retorts

Steady-state Stream Factor

Raw Shale Feed Rate

Shale Properties

Grade

Size Requirements

Product Recovered

Recovery (crude oil)

Deashed Shale Oil

Spent Shale

AGR Make Gas

Sour Water
Lawrence Livermore National Laboratory HRS

One

$95 \%$

950 TPCD

1,000 TPSD

27 GPT

$-1 / 4$ " 
The utility systems that are included in the Case 2 Demonstration Plant are:

- Mine Water System

- Cooling Water System

- Inert Gas Generation System

- Instrument and Plant Air System

- Fuel Gas System

- Potable Water System

- Fire Water System

- Service Water System

- Oily/Storm Water System

- Sanitary Sewer System

The offsite facilities that are included in the Case 2, Demonstration Plant are:

- Power Distribution

- Interconnecting Pipeways

- Buildings

- Site Preparation and Development

- Mobile Equipment

- Tank Farm

- Rifle Marshalling Yard

- Emergency Flare System

- Control System

CASE 3 - Pilot Plant

As noted at the beginning of this section, Case 3 incorporates only the materials handling and the HRS above ground retort. A block flow diagram of the pilot size plant is presented in Figure 3-3.

Mined Shale Handling and Processing

The shale feed for the pilot plant will be from an existing stockpile of shale generated during the early mine development work.

\section{Local Coarse Shale Stockpile}

Nominal/Rock Size

Bulk Density of Rock

Fines Present in Rock

Rock Surface Moisture

Normal Reclaim Rate
-8 " nominal, $20 " \times 12 " \times 8$ "

max. lump size

$80 \mathrm{lb} / \mathrm{cu} \mathrm{ft}$

$5 \%$

$2 \%$

$5 \mathrm{TPSH}$ 
Primary Crushing

Normal Feed Rate

5 TPSH

Feed Size

$+2^{n} \times-10^{n}$

Product Size

Type of Crusher

Redundancy

$-2^{n}$

Double Roll

$100 \%$ spare

\section{Secondary Crushing}

Normal Feed Rate

Feed Size

5 TPSH

Product Size

$-2^{n}$

$-1 / 4^{n} \times 0$

Type of Crusher

Single Roll

Redundancy

$100 \%$ spare

\section{Surge Bin}

Purpose

2-1/2 hr storage for final feed to the HRS retort during interrupted supply from crushing plant

\section{Dust Control}

Storage Pile to Lowering Well

Reclaim from Storage Pile

Weather Protection

Crushers

Fine Ore Surge Bin

Elevated Transfer House

Conveyors

Control Room and Laboratory
Water Sprays

Baghouses
Closed building (maintained above freezing)

Closed building (maintained above freezing)

Roof with open sides

Covered

Closed building, heated $\left(68^{\circ} \mathrm{F}\right)$ and pressured

Above Ground Retorting Facilities

Retort Technology

Number of Retorts

Steady-state Stream Factor

Raw Shale Feed Rate
Lawrence Livermore National Laboratory HRS

One

$95 \%$

95 TPCD 
100 TPSD

Shale Properties

Grade

Size Requirements

27 GPT

$-1 / 4^{\prime \prime}$

Product Recovered

Recovery (crude oil)

$96 \%$

Deashed Shale Oil

58 BPCD

62 BPSD

Spent shale

79 TPCD

83 TPSD

3 TPSD

AGR Make Gas

0.5 TPSD

Pneumatic Transport

Spent Shale

79 TPCD

83 TPSD

Transport Air

684 MSCFCD

720 MSCFSD

Quench Water

8.200 Gal/CD

$8,640 \mathrm{Gal} / \mathrm{SD}$

\section{Gas Clean up}

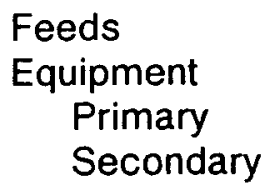

Retort Flue Gas Spent Shale

Cyclone

Baghouse

\section{Utilities/Offsites}

The required utilities for the Case 3, Pilot Plant, will be supplied to the unit battery limits from existing or temporary facilities.

The temporary offsite facilities that will be provided for the Case 3 , Pilot Plant are:

- Power Distribution

- Interconnecting Pipeways

- Buildings

- Site Preparation and Development

- Mobile Equipment

- Tank Farm

- Emergency Flare System

- Control System 
Table 3-1

\section{Design Criteria}

Basis

Case 1

Case 2/2A

Commercial

C-b tract

Site

Location

\section{Mining Facilities}

Mine type

Classification

Mining Method

Oil shale Grade

Productions Days

Annual Production

\section{MIS Retort Development Mining}

\section{Facilities}

Mining Method

Oil Shale Grade

- mined to AGR/CFBC

- rubblized-in-place

Production Days

Annual Production

Material Handling Facilities

Local Coarse Shale Stockpile

Remote Coarse Shale Stockpile

Retort Feed Storage

Aboveground Retort Facilities (AGR)

Retort Technology

Retort Feed

Feed Shale Grade

Steady State Stream Factor

No. of Retorts
Rio Blanco County

Shaft Mine

Gassy-Nonmetal

-

0

Rm. \& Pillar (ea. void level)

$$
\begin{aligned}
& 27 \text { GPT Average } \\
& 27 \text { GPT Average } \\
& 357 \text { Days per Year } \\
& \text { 4,700,000 Tons }
\end{aligned}
$$

37,000 T Live, 13,500 T Dead

3.6 Million Tons

7,000 Tons (13 hours)

LLNL HRS

12.800 TPSD

27 Gallons per Ton 95\%
Demonstration

$$
\text { C-b tract }
$$

Rio Blanco County

Shaft Mine

Gassy-Nonmetal

0

Rm. \& Pillar (ea. void level)

$$
\begin{aligned}
& 27 \text { GPT Average } \\
& 27 \text { GPT Average } \\
& 357 \text { Days per Year } \\
& 420,000 \text { Tons }
\end{aligned}
$$

$4500 \mathrm{~T}$ Live, 13,500 T Dead

LLNL HAS

1000 TPSD

27 Gallons per Ton

$95 \%$

\section{Case 3}

Pilot

C-b Tract

Rio Blanco County

N/A

N/A
Coarse shale stockpile from mine development

LLNL HRS

100 TPSD

27 Gallons per Ton $95 \%$ 
Table 3-1

\section{Design Criteria (Continued)}

\section{Basis}

Modified in Silu Processing Facilities

Underground Retorting System

Retort Technology

Retorn Processing Rate

\section{Oil Upgrading Facilities}

Hydrotreating Technology

Normal Feed Rate

Sulfur Removal Technology

Syncrude Production

\section{Syncrude Pipeline Facilities \\ Capacity}

Destination

Utilities and Offsite Facilities

Intermediate and Syncrude Tankage

Water Source

Overrapacity

Power Source

Coal

Feed to CFBC, TPD

Coal Stockpile,Tons

Feed Storage,Tons

Capacity of Product/By-Products

Light OıI, BPCD

Bulkhead Oil, BPCD

Power to Grid, MW

Treated Oil, BPCD

Case 1

Case 2/2A

Case 3

Occidental MIS Technology 22 Retorts Burning Simultaneously

1 Retort Ignited Every 14 Days

27.5 Retorts Processed per Year

Union Oil

21.894 BPSD (20.799 BPCD)

Claus Unit

8.4 Million Barrels per Year

23.000 BPCD

Chevron Rangely Terminal

\section{7 days}

Mine Inflow supplemented with wells

Minimal

Power generated at site

1044
7000

250

$-$
Occidental MIS Technology

2 Retorts Burning Simultaneously

1 Retort Ignited Every 146 Days

2.5 Retorts Processed per Year
N/A

N/A

15 days storage for light and

bulkhead

Mine Inflow supplemented with wells Mine in flow supplemented with wells

Minimal

Minimal

Power generated at site

Purchased

* Raw untreated shale oil. 
Figure 3-1

BLOCK FLOW DIAGRAM

COMMERCIAL SIZE PLANT

CASE 1

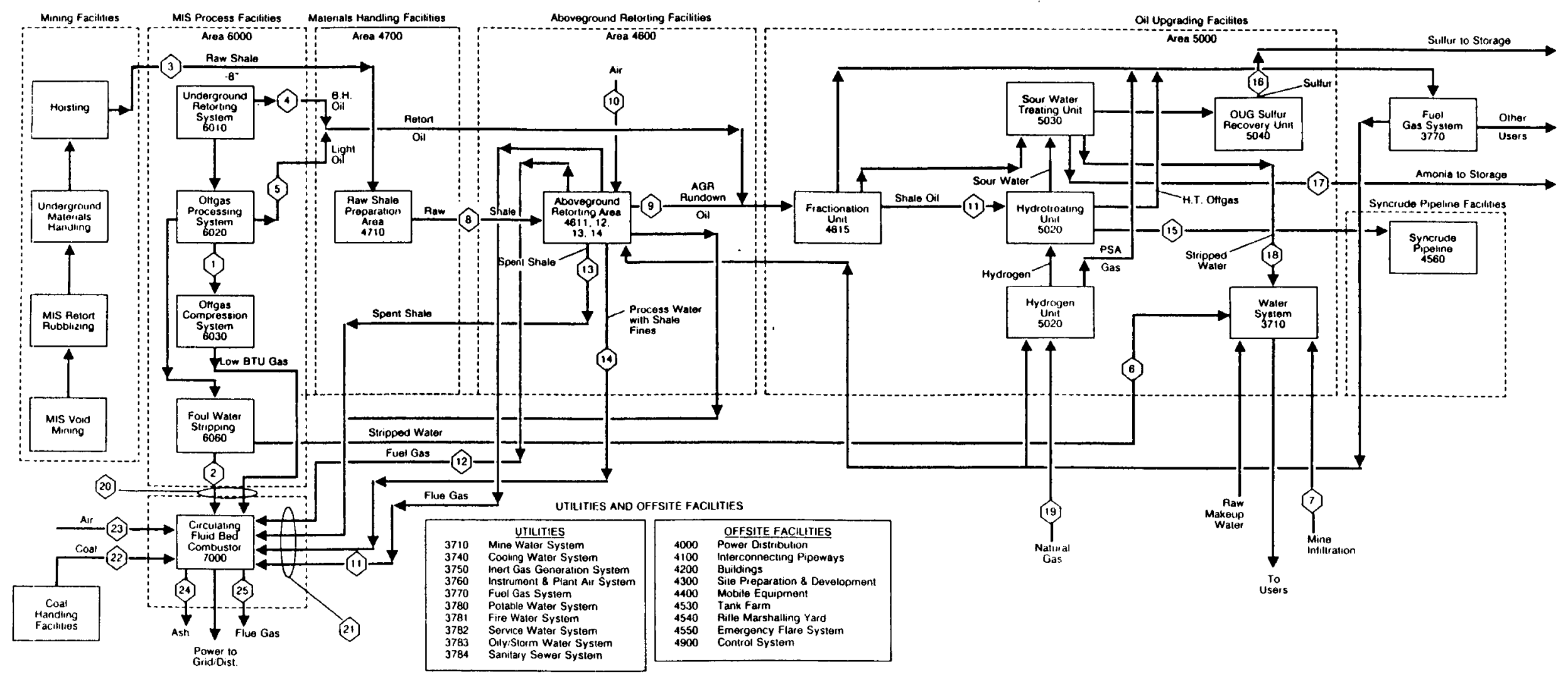


Figure 3-2

BLOCK FLOW DIAGRAM

DEMONSTRATION SIZE PLANT

CASES 2, 2A

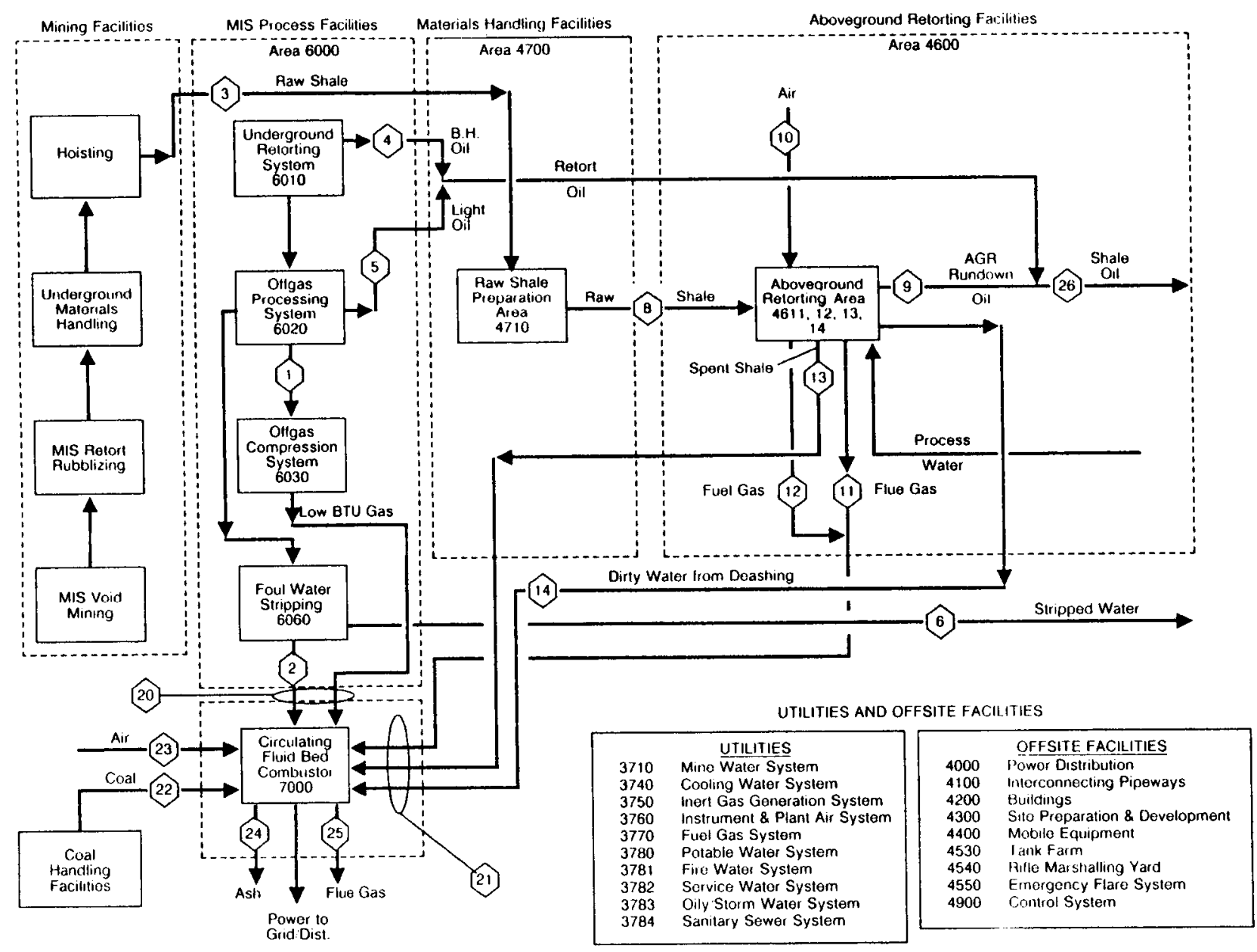


Figure 3-3

\section{BLOCK FLOW DIAGRAM \\ PILOT SCALE PLANT \\ CASE 3}

Raw Shale

from Stockpile

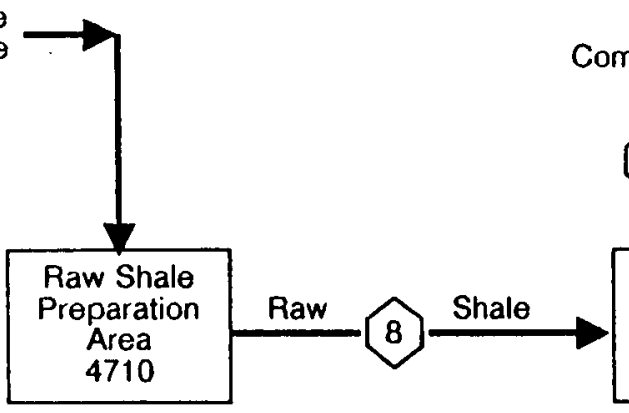

Combustion

$$
\text { Air }
$$

1.

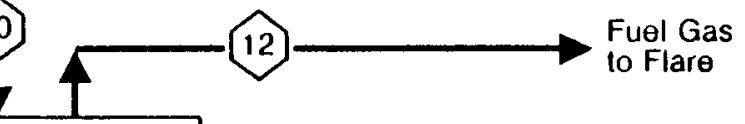

Aboveground AGR

$\begin{aligned} & \text { Retoring Area } \\ & 4611,12,13,\end{aligned}-$ Oil $\rightarrow$ Ro Storage

14 Process Water

Spent Shale

Flue Gas
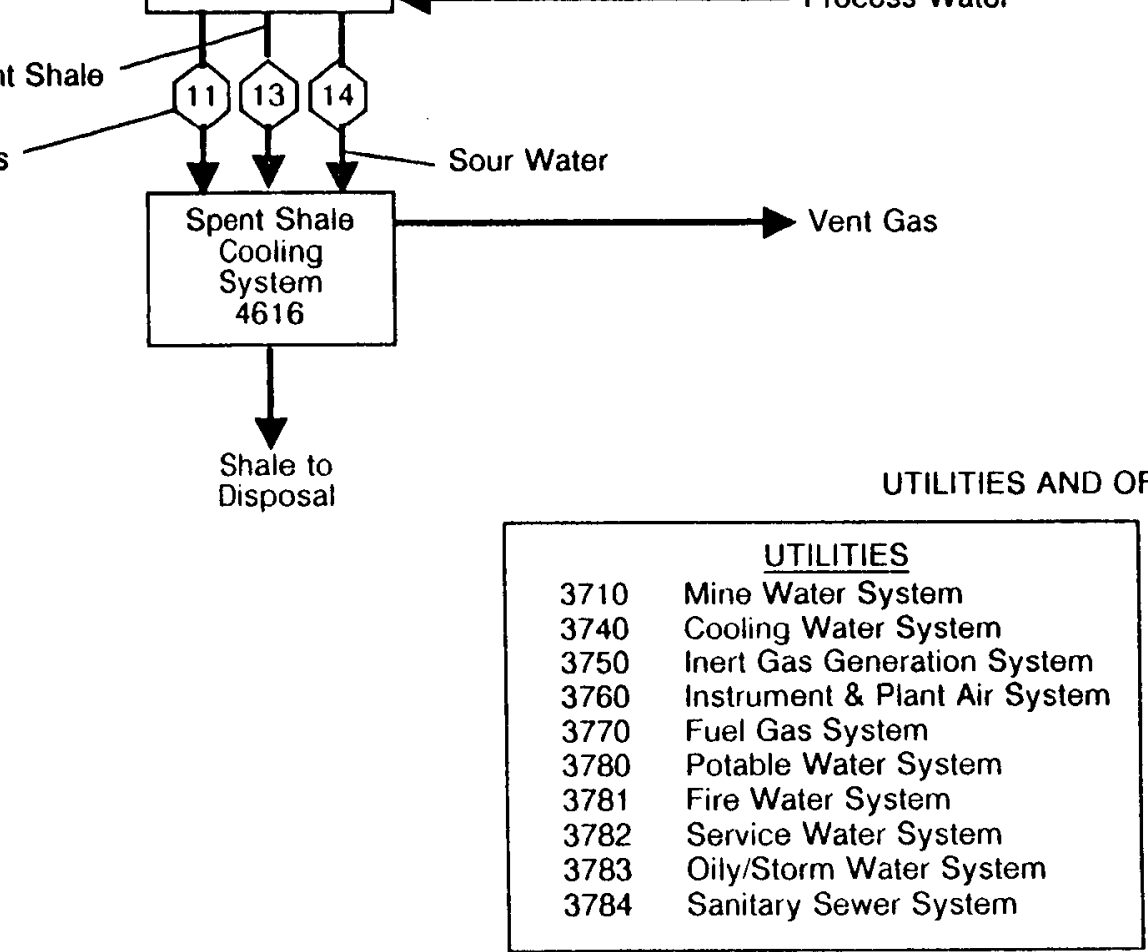

\begin{tabular}{|ll|}
\hline & OFFSITE FACILITIES \\
4000 & Power Distribution \\
4100 & Interconnecting Pipeways \\
4200 & Buildings \\
4300 & Site Preparation \& Development \\
4400 & Mobile Equipment \\
4530 & Tank Farm \\
4540 & Rifle Marshalling Yard \\
4550 & Emergency Flare System \\
4900 & Control System \\
\hline
\end{tabular}




\section{costs}

The capital and operating costs for the cases presented in this report are based on criteria, design basis and facilities described in the Design Basis and Process Description sections. These sections summarize the extensive technical information generated during the period 1982 through 1989.

CAPITAL COSTS

The capital costs for the cases are summarized in Table 4-1. The total installed costs for the facility are determined by adding indirect field costs, home office costs, spare parts, sales tax, county tax and unallocated cost/royalties. The accuracy of the estimate is predicted to be $+1-30$ percent. The cost basis is mid1989.

- Mining costs were calculated for the Commercial and the Demonstration facilities by the mining consulting firm of Agapito and Associates, Inc. Copies of the reports are in the appendix.

- A detailed equipment list was generated for the HRS Above Ground Retort (Units 4611, 4612, 4613, 4614). Current pricing is used to determine the mid-1989 costs.

- Oil upgrading Facilities (Area 5000) are essentially the same as before and were adjusted to reflect the amount of oil being processed in Area 5000. A capacity and escalation factor was used to prorate the costs from the 1987 estimate to a mid-1989 basis.

- Shale Handling Facilities (Area 4700) including Coal Handling are based on the flow sketches shown on Figures $7-8,7-9$, and $7-10$.

- Utilities and Offsite Facilities (Areas 3700/4000-4500/4900) were adjusted to reflect new balances. A capacity and escalation factor was used to adjust costs from the 1987 estimate which was then escalated to a mid-1989 basis.

- Syncrude Pipeline (Area 4560) costs were modified by using a capacity and escalation factor to update costs from the 1987 estimate. 
- The price estimate for the complete CFBC/Power Generation (Area 7000) is based on vendor information.

- The costs for indirect cost, home office costs, spare parts, and state and local tax are calculated as a percentage of direct cost. The percentages used were determined from the 1987 estimate.

- The capitalized unallocated cost and royalties include the Occidental management, engineering, environmental, and accounting staff expenses during the design and construction of the facility. It also includes the ad valorem taxes on improvements on the site as the equipment is installed. In the commercial case, Case 1, it includes the Union Oil hydrotreating royalty as a capitalized lump sum.

\section{OPERATING COSTS}

The steady-state operating costs are summarized in Table 4-2 for all of the cases developed in this study. The costs were developed using utility balances, estimates of manpower, estimates of catalyst and chemicals, and historical factors.

- Natural Gas. The cost of natural gas is assumed to be $\$ 2.00$ per million BTU which reflects the current gas pricing in the area. The consumptions were calculated for each case.

- Coal. A small quantity of coal is consumed in the CFBC to provide additional heat for flame stability. This can be clean coal or lower value cleaning plant refuse from nearby coal mines in the Meeker area. For the economic analysis, it has been assumed that local coal mines would furnish the coal at $\$ 1.25 /$ MMBTU delivered by truck from their mine.

- Electric Power. Power balances were made for each case. Due to the excess power generated in Cases 1, 2, and 2A, no power is purchased in these cases; in fact these cases generate surplus power for sale. Case 3, the pilot plant, purchases power. Pricing of the purchased power and surplus power is 5 cents per kilowatt hour.

- Chemicals and Catalyst. Annual consumptions of catalyst and chemicals were calculated based upon processing requirements. Unit prices were then used to arrive at annual costs. 
- Maintenance Materials. Annual cost of maintenance materials, maintenance labor and contract maintenance labor was calculated at seven (7) percent of the material cost of the plant facilities.

- Operating Labor. Annual operating labor costs were estimated using an average annual rate of $\$ 40,000$ per year per laborer. The estimated manpower requirements are shown in Table 4-3.

- Spent Shale Disposal. Spent shale disposal costs were scaled annual costs from detailed disposal plans developed in 1984-1985. The costs were scaled upon the quantity of spent shale for disposal.

- Retort Rubblization and Construction. The cost to drill and rubblize the MIS retort after it is mined out to the proper void fraction is $\$ 0.5$ million per retort. The cost to construct the MIS retort bulkheads and too install the necessary piping and instrumentation is $\$ 1.1$ million per retort.

- Mining Costs. The mining costs were developed by Agapito \& Associates using plans for the demonstration and commercial mines. The costs include all mining labor costs, supplies and equipment. The above costs for electric power and natural gas are included based on the overall utility balance.

- Unallocated Support. The unallocated support costs include the administrative and technical staff required to operate the project for each case. Table 4-4 presents a summary of office staffing and expenses and the ad valorem taxes. The ad valorem taxes (property taxes) are estimated at 1.8 percent of the direct field cost of the plant.

\section{PRODUCTS AND BY PRODUCTS}

The steady state product and by product production rates, assumed values and annual credits are summarized in Table 4-5.

- Shale Oil. The raw shale is credited at $\$ 18.50$ per barrel at the plant gate. the hydrotreated syncrude is credited at $\$ 24.50^{\circ}$ per barrel at the plant gate. Based upon discussions with Union Oil, syncrude could be worth $\$ 3$ to $\$ 6$ per barrel more than conventional crude.

- Electric Power. The credit for surplus power sales is based upon current avoided costs in Colorado under the Public Utilities Regulatory Policy Act (PURPA). Currently power is 
purchased by Public Service of Colorado at 5 cents per kilowatt hour.

- Sulfur. The credit for elemental sulfur produced in Case 1 is $\$ 50$ per ton based upon U.S. Gulf Coast prices adjusted for shipping charges.

- Ammonia. The credit for anhydrous ammonia produced in Case 1 in the wastewater treatment is $\$ 80$ per ton based upon current prices in the region. 
Table 4-1

CAPITAL COST SUMMARY

(S Millions)

\begin{tabular}{|c|c|c|c|c|c|}
\hline \multicolumn{6}{|l|}{ AREA/UNIT } \\
\hline NUMBER & DESCRIPTION & CASE 1 & CASE 2 & CASE 2A & CASE 3 \\
\hline -. & MINE & 148.3 & 27.0 & 27.0 & 0.0 \\
\hline-- & MIS RETORT RUBBLIZATION \& CONSTRUCTION & 34.6 & 4.2 & 4.2 & 0.0 \\
\hline 3700 & UTILITIES & 16.8 & 5.2 & 5.2 & 0.0 \\
\hline 4000 & POWER DISTRIBUTION & 15.7 & 4.9 & 4.9 & 0.0 \\
\hline 4100 & INTERCONHECTING PIPEWAYS & 16.8 & 4.3 & 4.3 & 0.0 \\
\hline 4200 & BUILDINGS & 21.3 & 13.8 & 13.8 & 0.5 \\
\hline 4300 & SITE PREPARATION \& DEVELOPMENT & 16.8 & 5.8 & 5.8 & 0.2 \\
\hline 4400 & MOBILE EQUIPMENT & 6.7 & 2.9 & 2.9 & 0.1 \\
\hline 4500 & TANK FARM, YARD \& FLARE & 7.8 & 1.2 & 1.2 & 0.0 \\
\hline 4560 & SYNCRUDE PIPELINE & 11.2 & 0.0 & 0.0 & 0.0 \\
\hline $4611-14$ & HRS RETORT, QUENCH, DEASHING \& RECYCLE GAS & 31.5 & 11.6 & 11.6 & 9.2 \\
\hline 4615 & FRACTIONATION & 9.5 & 0.0 & 0.0 & 0.0 \\
\hline 4700 & SHALE PREPARATION \& HANDLING & 6.6 & 4.0 & 4.0 & 0.7 \\
\hline 4900 & CONTROL SYSTEMS & 4.4 & 1.1 & 1.1 & 0.0 \\
\hline 5000 & OIL UPGRADING FACILITIES & 121.0 & 0.0 & 0.0 & 0.0 \\
\hline 6000 & MIS PROCESS FACILITIES & 134.7 & 23.4 & 23.4 & 0.0 \\
\hline 7000 & CFBC/POWER GENERATION & 162.5 & 52.3 & 43.6 & 0.0 \\
\hline & TOTAL DIRECT FIELD COST & 766.2 & 161.7 & 153.0 & 10.7 \\
\hline & INDIRECT FIELD COST & 188.7 & 39.8 & 37.7 & 2.6 \\
\hline & TOTAL FIELD COST & 954.9 & 201.5 & 190.7 & 13.3 \\
\hline & HOME OFFICE COST & 106.6 & 22.5 & 21.3 & 1.5 \\
\hline & TOTAL FIELD AND HOME OFFICE COST & 1061.5 & 224.0 & 212.0 & 14.8 \\
\hline & SPARE PARTS & 7.1 & 1.5 & 1.4 & 0.1 \\
\hline & STATE \& LOCAL TAXES & 25.4 & 5.4 & 5.1 & 0.3 \\
\hline & UNALLOCATED COST AND ROYALTIES & 68.8 & 12.6 & 12.4 & 4.3 \\
\hline & TOTAL PROJECT COST & 1162.8 & 243.5 & 230.9 & 19.5 \\
\hline
\end{tabular}

The sunk capital costs expended to-date are not included in the capital costs listed above.

A $2 \cdot 5 \times>0$ 
Table 4-2

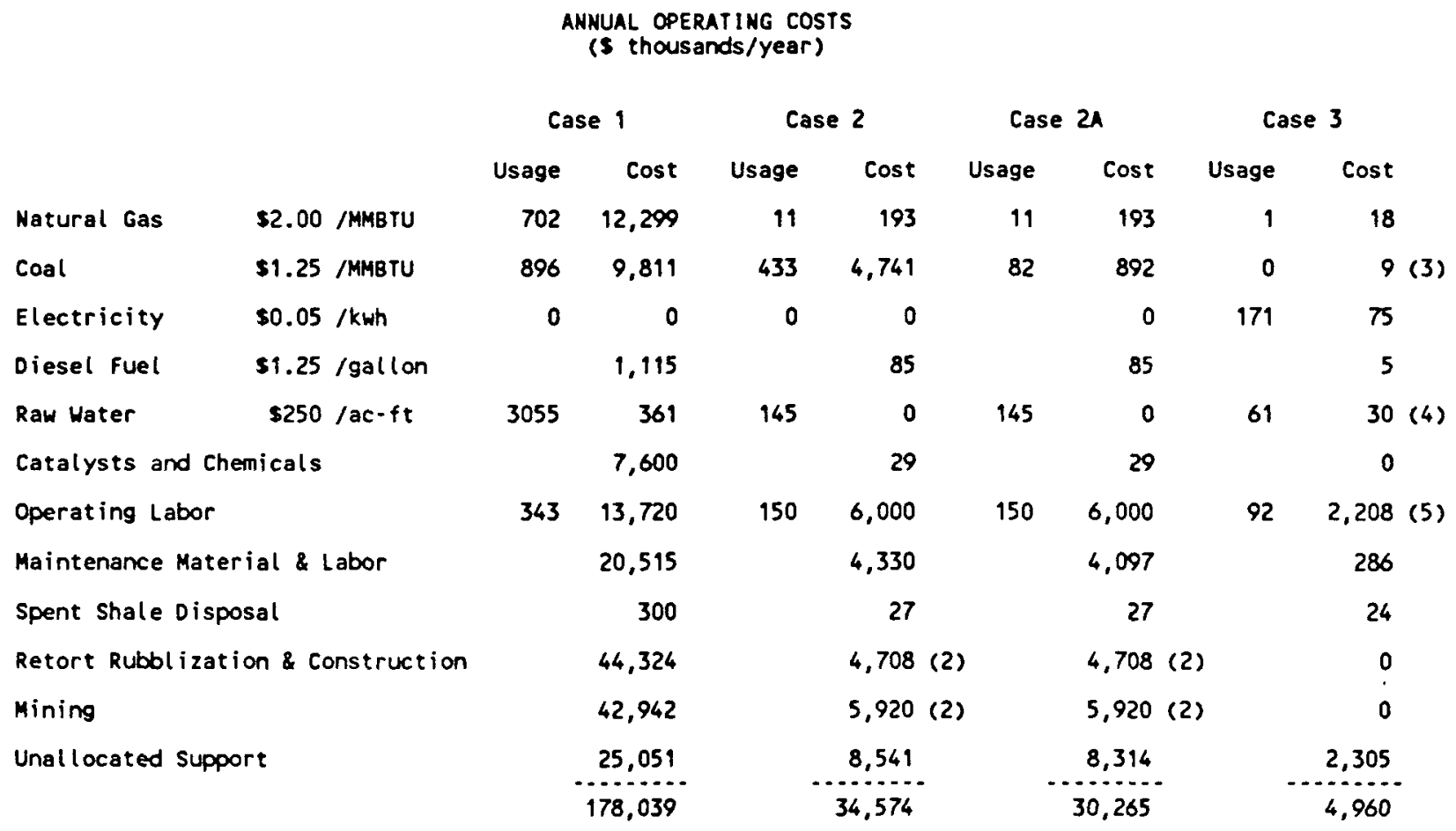

\section{Notes:}

1. Does not include income taxes or federal lease royalties.

2. First year of operation costs. Retort rubblization complete in two years of operation and retort construction in four years. Mining costs decrease for next two years as mining of retorts is completed.

3. Cost to dig and crush shale for feedstock.

4. Costs for raw water and for a steam boiler and water treating.

5. Cost for contract operators and maintenance for $1 / 2$ year. 
Table 4-3

ESTIMATED MANPOWER REQUIREMENTS *

\begin{tabular}{|c|c|c|c|c|}
\hline AREA DESCRIPTION & Case 1 & Case 2 & Case 2A & Case 3 \\
\hline \multicolumn{5}{|l|}{ Process Operators } \\
\hline $\begin{array}{l}\text { Hoisting \& Materials Handling } \\
\text { Above Ground Retorting } \\
\text { MIS: Surface } \\
\text { MIS: Underground } \\
\text { CFCB and Generator } \\
\text { Oil Upgrading } \\
\text { Offsites and Utilities } \\
\text { Relief }\end{array}$ & $\begin{array}{r}28 \\
20 \\
40 \\
24 \\
8 \\
16 \\
12 \\
12\end{array}$ & $\begin{array}{r}20 \\
12 \\
12 \\
12 \\
8 \\
-2 \\
8 \\
10\end{array}$ & $\begin{array}{r}20 \\
12 \\
12 \\
12 \\
8 \\
- \\
8 \\
10\end{array}$ & $\begin{array}{r}8 \\
16 \\
- \\
- \\
- \\
- \\
8 \\
6\end{array}$ \\
\hline Total Operators & 160 & 82 & 82 & 38 \\
\hline Operations Supervision & 40 & 8 & 8 & 8 \\
\hline \multicolumn{5}{|l|}{ Maintenance Labor } \\
\hline $\begin{array}{l}\text { Hoisting \& Materials Handling } \\
\text { Above Ground Retorting } \\
\text { MIS: Surface } \\
\text { MIS: Underground } \\
\text { CFCB and Generator } \\
\text { Oil Upgrading } \\
\text { Offsites and Utilities } \\
\text { site Maintenance }\end{array}$ & $\begin{array}{r}21 \\
24 \\
24 \\
12 \\
8 \\
24 \\
10 \\
10\end{array}$ & $\begin{array}{r}6 \\
10 \\
6 \\
6 \\
8 \\
-2 \\
6 \\
10\end{array}$ & $\begin{array}{r}6 \\
10 \\
6 \\
6 \\
8 \\
-8 \\
6 \\
10\end{array}$ & $\begin{array}{r}8 \\
16 \\
\therefore \\
-. \\
-- \\
- \\
8 \\
10\end{array}$ \\
\hline Total Maintenance Labor & 133 & 52 & 52 & 42 \\
\hline Maintenance Supervision & 10 & 8 & 8 & 4 \\
\hline $\begin{array}{l}\text { Total Operators and } \\
\text { Maintenance }\end{array}$ & 343 & 150 & 150 & 92 \\
\hline
\end{tabular}


Table 4-4

UNALLOCATED SUPPORT COSTS

(Office Salaries and Expenses plus Ad Valorem Taxes) ( $\$$ thousands per year)

President

Secretary

Project Director

Technical Manager

Chemical Engineers

Mechanical Engineers

Electrical Engineers

Mine Engineers

Blasting

Geologist

Construction Manager

Project Engineer

Enviromental Manager

Air

Hater

Reporting

Samolers

Health \& Safety

Inspectors

Accounting Manager

Account ants

Payroll

Personnel Administraton

Clerk

Secretaries

Legal

Public Affairs

Laboratory

Chief Chemist

Chemists

Total Direct Payroll Expense

Salary fringe and Benefits

Total Wages and Benefits

Office Expense

Travel Expense

Corporate Charges

Bonds \& Insurance

Unit
Salary
sk/yr
150
30
115
100
70
65
65
60
95
70
90
60
75
60
40
40
35
50
40
85
40
30
60
20
25
100
55
75
50

$$
\begin{gathered}
\text { Commercial } \\
\text { Plant } \\
\text { Case - 1 } \\
\text { No. \$k/yr }
\end{gathered}
$$

1150

1

1100

2140

2130

$1 \quad 65$

2120

195

190

2120

175

$1 \quad 60$

140

$4 \quad 140$

$1 \quad 50$

3120

280

260

160

240

4100

$1 \quad 100$

50

$\begin{array}{rr}1 & 75 \\ 2 & 100 \\ 46 & 2545 \\ 45 \times 1145.2\end{array}$

Subtotal

Ad Valorem Taxes
3690.2

500
250

600

Demonstration Plant

Case -2
NO. $\$ k / y r$

$$
1150
$$

$1 \quad 30$

$\begin{array}{ll}1 & 115 \\ 1 & 100\end{array}$

2140

2130

$1 \quad 65$

195

$\begin{array}{ll}1 & 70 \\ 1 & 90\end{array}$

160

$1 \quad 60$

$1 \quad 40$

$4 \quad 140$

$\begin{array}{rr}1 & 50 \\ 3 & 120\end{array}$

185

280

130

120

$\begin{array}{rr}3 & 75 \\ 1 & 100 \\ 1 & 55\end{array}$

1

$\begin{array}{rr}1 & 75 \\ 1 & 50 \\ 38 & 2185\end{array}$

983.25

3168.2

500

250

400

5040.2

20011

25051

4318.2

4222

8541
Case - 2A NO. $\$ k / y r$

Pilot Plant

Case - 3 No. $\$ k / y r$

$\begin{array}{rr}1 & 150 \\ 1 & 30 \\ 1 & 115 \\ 1 & 100 \\ 2 & 140 \\ 2 & 130 \\ 1 & 65 \\ 1 & 60 \\ 1 & 95 \\ 1 & 70 \\ 1 & 90 \\ 1 & 60 \\ & 0 \\ 1 & 60 \\ 1 & 40 \\ 1 & 40 \\ 4 & 140 \\ 1 & 50 \\ 3 & 120 \\ 1 & 85 \\ 2 & 80 \\ 1 & 30 \\ 1 & 60 \\ 1 & 20 \\ 3 & 75 \\ 1 & 100 \\ 1 & 55\end{array}$

$\begin{array}{rr}1 & 75 \\ 1 & 50 \\ 38 & 2185 \\ & 983.25\end{array}$

3168.2
500
250

400

$1 \quad 150$

130

1

1

1

1

10

$1 \quad 40$

150

1

2

50

$\begin{array}{rr}1 & 75 \\ 2 & 100 \\ 17 & 880\end{array}$

396

1276

250

200

300

4318.2

2026

279

8314

2305 


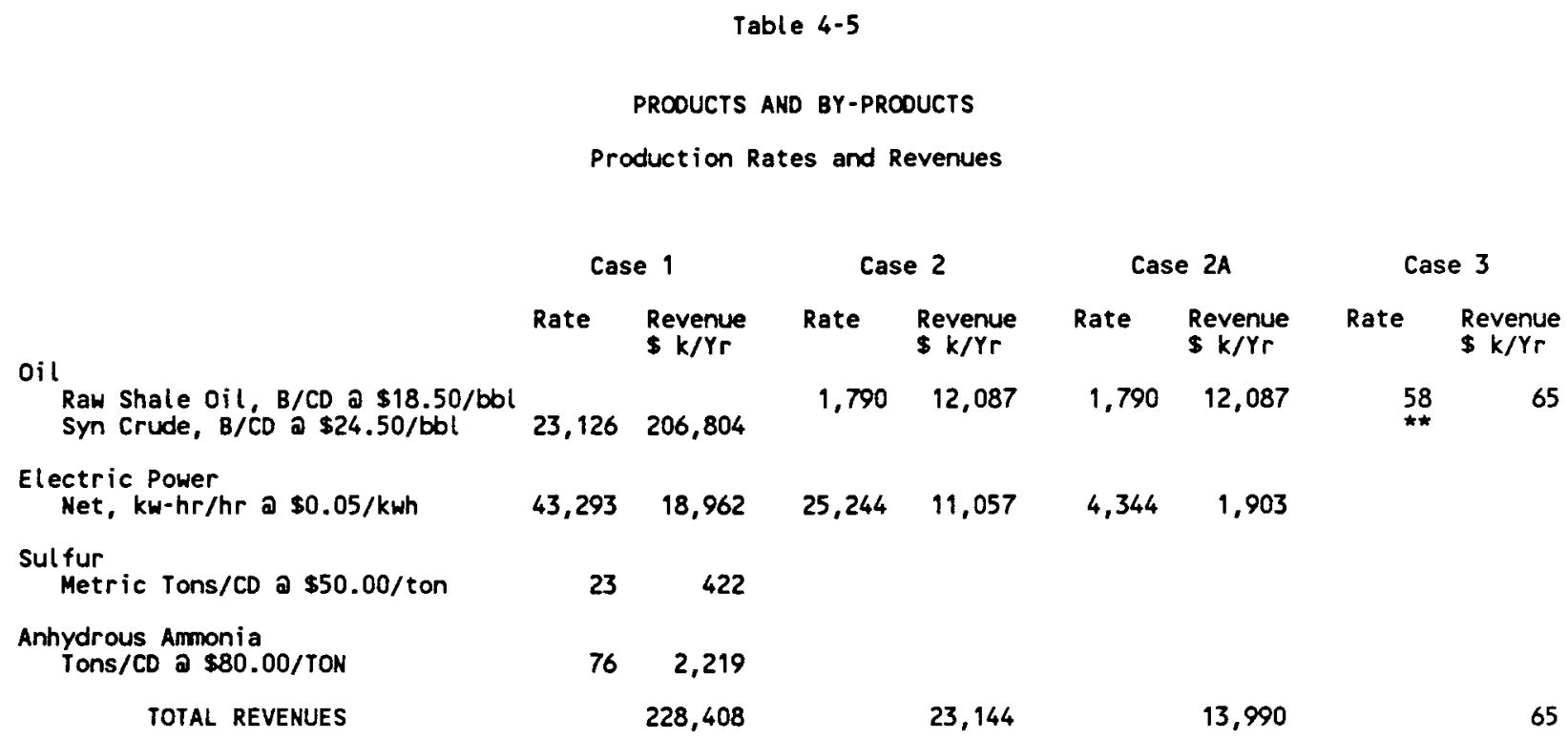

** Pilot plant operation will produce 2 months of rated capacity of oil. 


\section{SCHEDULE}

CASE 1 - COMMERCIAL PLANT

The Commercial plant schedule is expected to require six years from kickoff to completion of the commissioning and startup activities. The project schedule is shown in Figure 5-1.

CASE 2/2A - DEMONSTRATION PLANT

The Demonstration plant schedule is expected to require four years from kickoff to completion of the commissioning and startup activities. The project schedule is shown in Figure 5-2.

\section{CASE 3 - PILOT PLANT}

The Pilot plant schedule is expected to require three years from kickoff to completion of the construction activities. The project schedule is shown in Figure 5-3.

If process development on the three cases is done sequentially, the overall schedule would be approximately 15 years. This allows the Pilot and Demonstration plants one year each of operation before design of the next size facility. A more economical alternate to straight sequential activities is an integrated Precommercialization schedule.

\section{PRE-COMMERCIALIZATION PLAN}

The Pre-commercialization plan, which integrates the schedules of the Pilot and Demonstration Plants, and takes into account the advanced readiness of the MIS retort, will take a total of 10 years. This integrated schedule would allow for a faster startup of the MIS Commercial size plant and accommodate the longer development schedule for the HRS process. The project schedule for the Precommercialization plan is presented in Figure 5-4. 
Figure 5-1

PROJECT SCHEDULE

CASE 1 - COMMERICAL

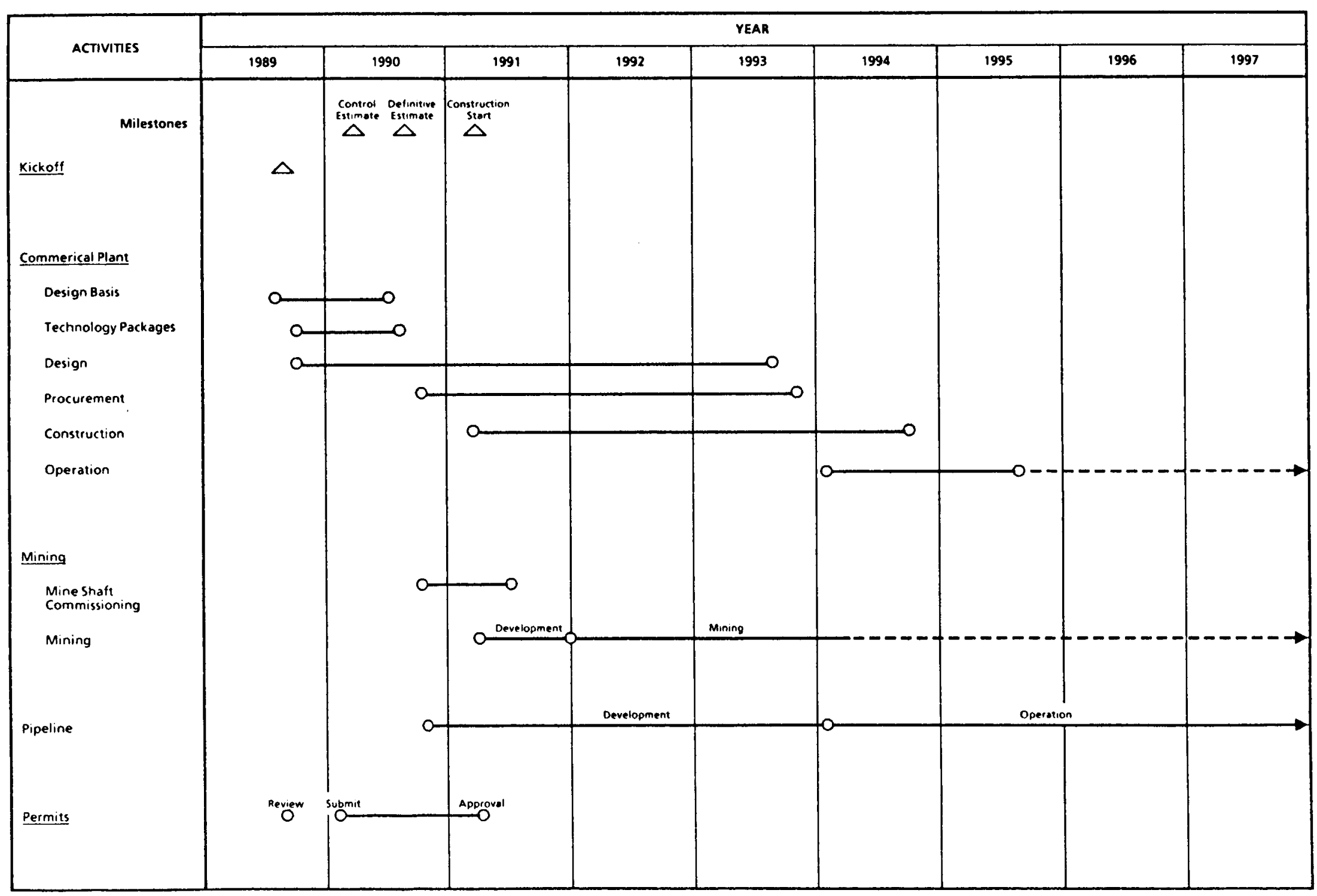


Figure 5-2

PROJECT SCHEDULE

CASE 2 AND $2 A$ - DEMONSTRATION

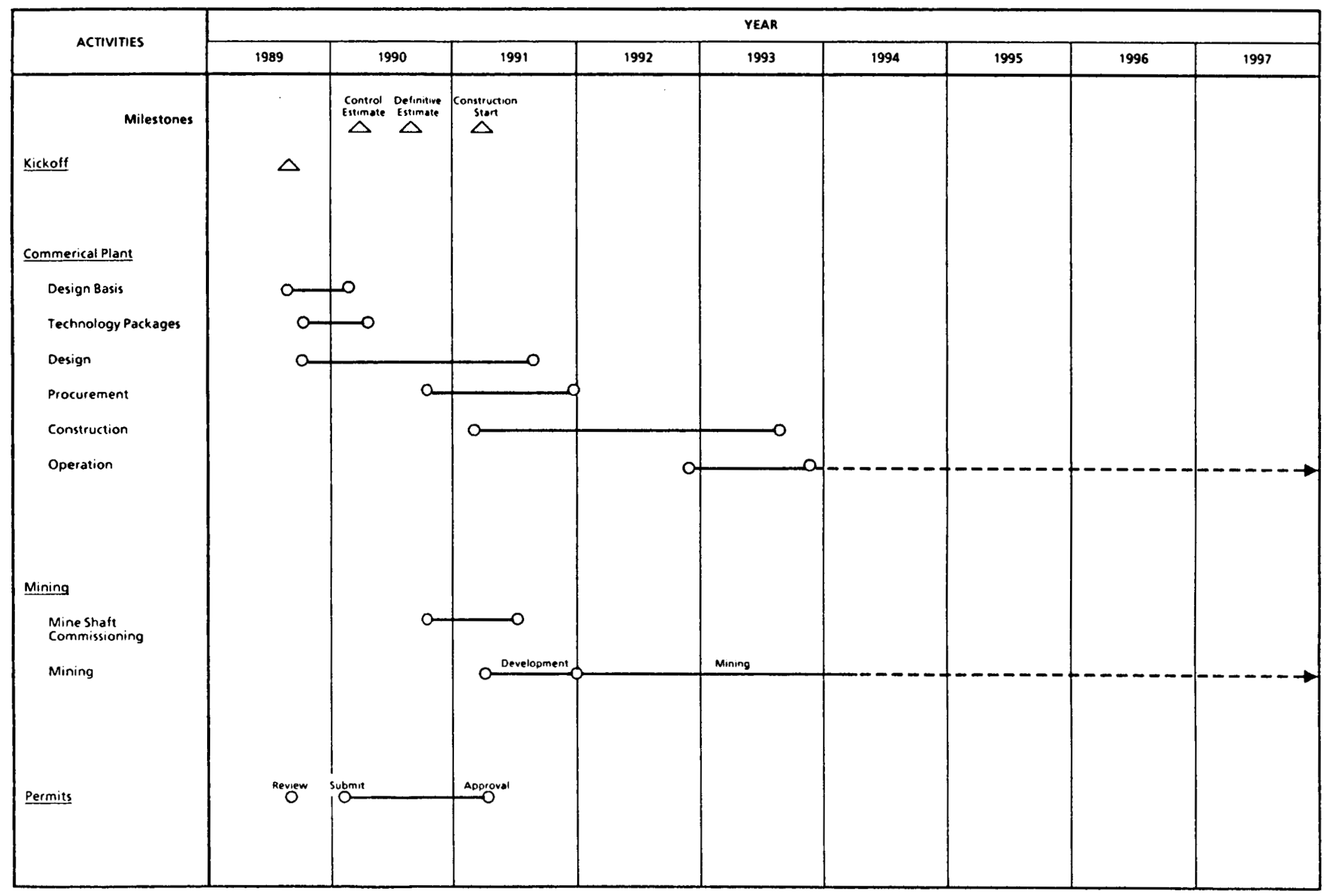


Figure 5-3

PROJECT SCHEDULE

CASE 3 - PILOT PLANT

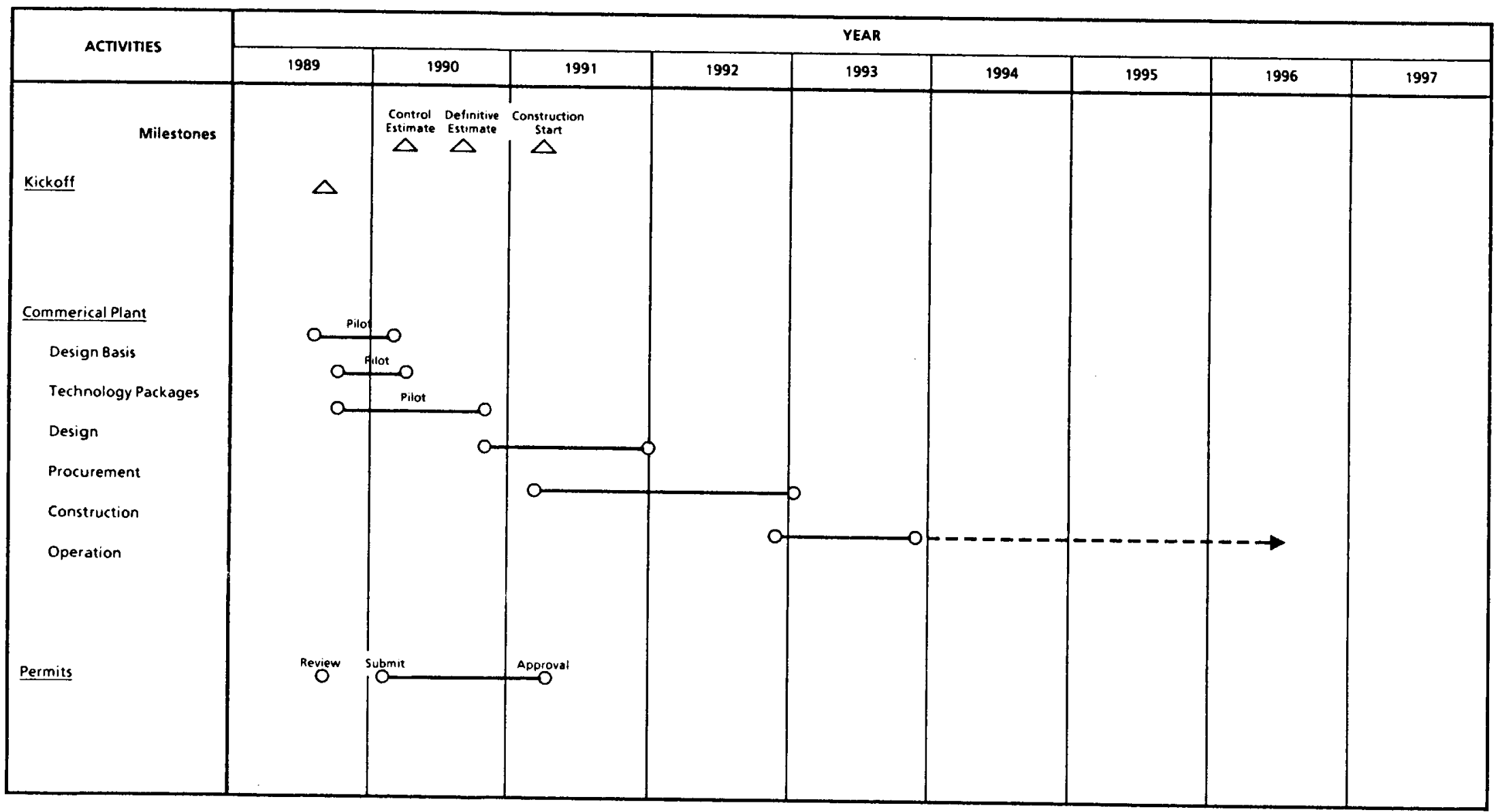


Figure 5-4

PRE-COMMERCIALIZATION SCHEDULE

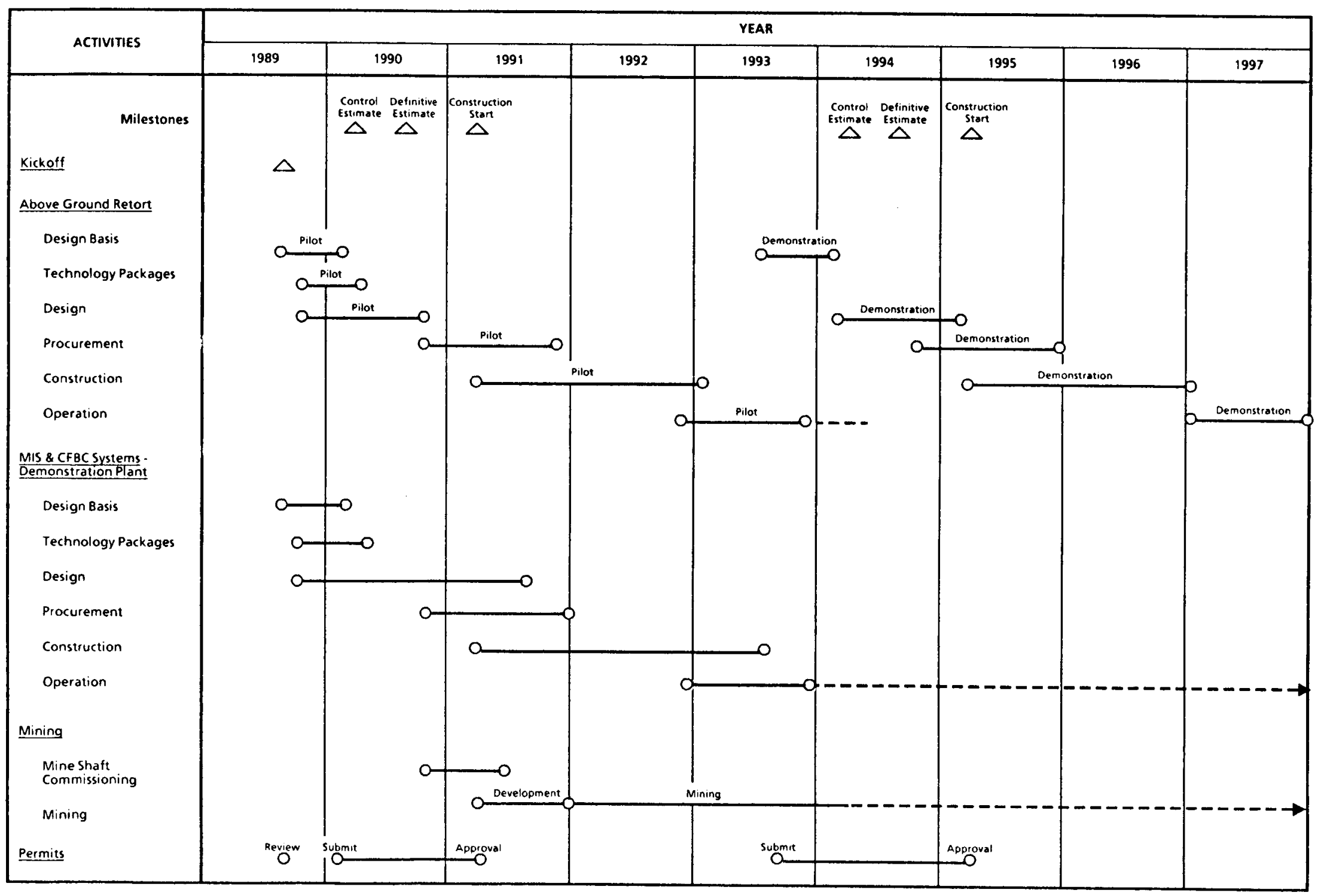




\section{ECONOMIC ANALYSIS}

SUMMARY

Financial analyses have been conducted for the commercial case, demonstration case and pilot plant case, Cases 1 to 3 respectively.

For the commercial case, Case 1, the financial analyses have generated oil prices in 1989 dollars required to produce an acceptable rate of return on the investment. For a 24,000 BPD plant, an oil price of $\$ 23.35$ per barrel will yield a 20 percent IRR for the financial assumptions of the model. This price can be interpreted as a per barrel oil price which generates enough revenue for the project to recover project costs including return on equity capital and debt service. These economics provide a first test of commercial project economics.

For the demonstration case and pilot plant case, the construction and operating costs for each program were developed for the complete program. The demonstration program is a 10 year program which totals $\$ 206.6$ million to construct the plant and operate it for seven years. If oil or electricity prices increase over inflation, the cost of the demonstration program decreases. The pilot program is a 4 year program to construct the pilot plant and operate it for one year to gather sufficient data to scale up the technology. The cost of the pilot program is $\$ 18.0$ million.

FINANCIAL ANALYSES

Using 1989 dollar estimates of capital and operating costs, the financial simulations determine the as spent cash flow requirements of the three cases. For the commercial case, the 1989 dollar oil price required to yield a target after tax return on equity was calculated for various assumptions.

Commercial Case

For the commercial facility, Case 1 , the financial results are summarized in Figure 6-1 and Table 6-1. Figure 6-1 shows the current oil price required to achieve returns on equity between 5 and 30 percent. The curves assume a financing structure of 75 percent debt and 25 percent equity, a 10 percent interest rate on debt and a 37.3 percent composite federal and state income tax rate. Curves were developed for oil prices increasing with inflation (at no real growth) and inflation plus two percent per year real 
growth. The required oil prices to yield a 20 percent return on equity are:

\section{$\$ 29.35 /$ Barrel at 0\% Real Growth}

$\$ 23.35 /$ Barrel at $2 \%$ Real Growth.

These oil prices are at the pipeline terminal and exclude transportation cost to a final destination. There is also no premium quality credit assumed for the hydrotreated syncrude which could be between 3 to 6 dollars per barrel.

A cash flow projections for the commercial case are included in Tables 6-1 and 6-2.

\section{Demonstration Case}

For the demonstration and pilot plant cases, Cases 2, 2A and 3, the capital and operating costs in 1989 dollars were escalated during the construction and operating periods. Tables 6-3, 6-4, and 6-5 show the as spent cash flow requirements of these programs. The cumulative cash flow requirements are summarized below.

\begin{tabular}{lcc} 
& \multicolumn{2}{c}{ \$ Millions (As Spent) } \\
& Before Tax & After Tax \\
Case 2 Demonstration & -318.4 & -206.6 \\
Case 1 Pilot & -27.9 & -18.0 \\
Pre-commercialization & -330.0 & -213.4
\end{tabular}

The demonstration program would provide a demonstration of the MIS technology on a continuous basis and a large scale demonstration of the LLNL retorting concept.

\section{ECONOMIC EVALUATION ASSUMPTIONS}

The analyses are based on the assumptions summarized in the tabulation on the following page and discussed in the paragraphs following this table.

The sunk capital cost expended to date are not included in the economic analysis consideration. $\Delta z-5-90$ 


\section{SUMMARY OF ECONOMIC EVALUATION ASSUMPTIONS}

\begin{tabular}{lccc} 
& Demonstration & Commercial & Pilot \\
Time basis for cost estimates & 1989 & 1989 & 1989 \\
Annual inflation rates (escalation), \% & 5 & 5 & 5 \\
Annual debt cost (interest rate), \% & None & 10 & None \\
Federal income tax rate, \% & 34 & 34 & 34 \\
State income tax rate, \% & 5 & 5 & 5 \\
Book life, years & 7 & 25 & 1 \\
Operating capacity factor, \% & $90-95$ & $90-95$ & $20-25$ \\
Depreciation tax life, years & 7 & 7 & 1 \\
Depreciation option & Double & Double & \\
declining & declining & \\
balance & balance & 2 \\
Timing & 3 & 5 & \\
\hline
\end{tabular}

The construction and operating period is: 4 years for the pilot case, 10 years for the demonstration case and 30 years for the commercial case.

Cash flows are assumed to occur at mid-year.

The cash flows are based on as-spent dollars; the required oil price results are expressed in constant mid-1989 dollars.

Return on Equity

Return on equity investment is computed as a discounted internal rate of return assuming a consolidated corporate return, using tax benefits as generated.

Tax Considerations

All capital equipment is assumed to have a seven-year useful life under the Tax Reform Act of 1986, except the pilot plant which is used only one year. 
Tax depreciation was calculated using the double declining balance factors presented below:

$\begin{array}{cccc}\text { Year } & \text { Percent } & \text { Year } & \text { Percent } \\ 1 & 14.3 & 5 & 8.9 \\ 2 & 24.5 & 6 & 8.9 \\ 3 & 17.5 & 7 & 8.9 \\ 4 & 12.5 & 8 & 4.4\end{array}$

Depreciation was assumed to begin when the equipment was ready to perform. The depreciation was calculated on one-half of the current year's and the previous years' investments.

In the commercial cases, preproduction costs are capitalized through start of operations and are expensed over the operating life of 25 years. Interest during construction is capitalized.

The mineral depletion allowance is the lesser of 15 percent of mining revenues or 50 percent of taxable income before depletion.

The effective combined state and federal income tax rate is assumed to be 37.3 percent, based on 5 percent state and 34 percent federal income tax rates.

\section{Federal Royalty}

The Federal lease royalty was based upon the actual tonnage of material mined and adjusted for grade and current oil price.

Debt Repayment

In the commercial projects, project financing was assumed at 75 percent debt and 25 percent equity. The demonstration cases were run at 100 percent equity since a demonstration case could probably not be financed on a project basis.

For the commercial cases, debt repayment was assumed to take place as a lump-sum payment after 25 years of operation. 
Table 6-1

CASH FLOW PROJECTIONS - OX REAL GROWTH

(s millions as spent

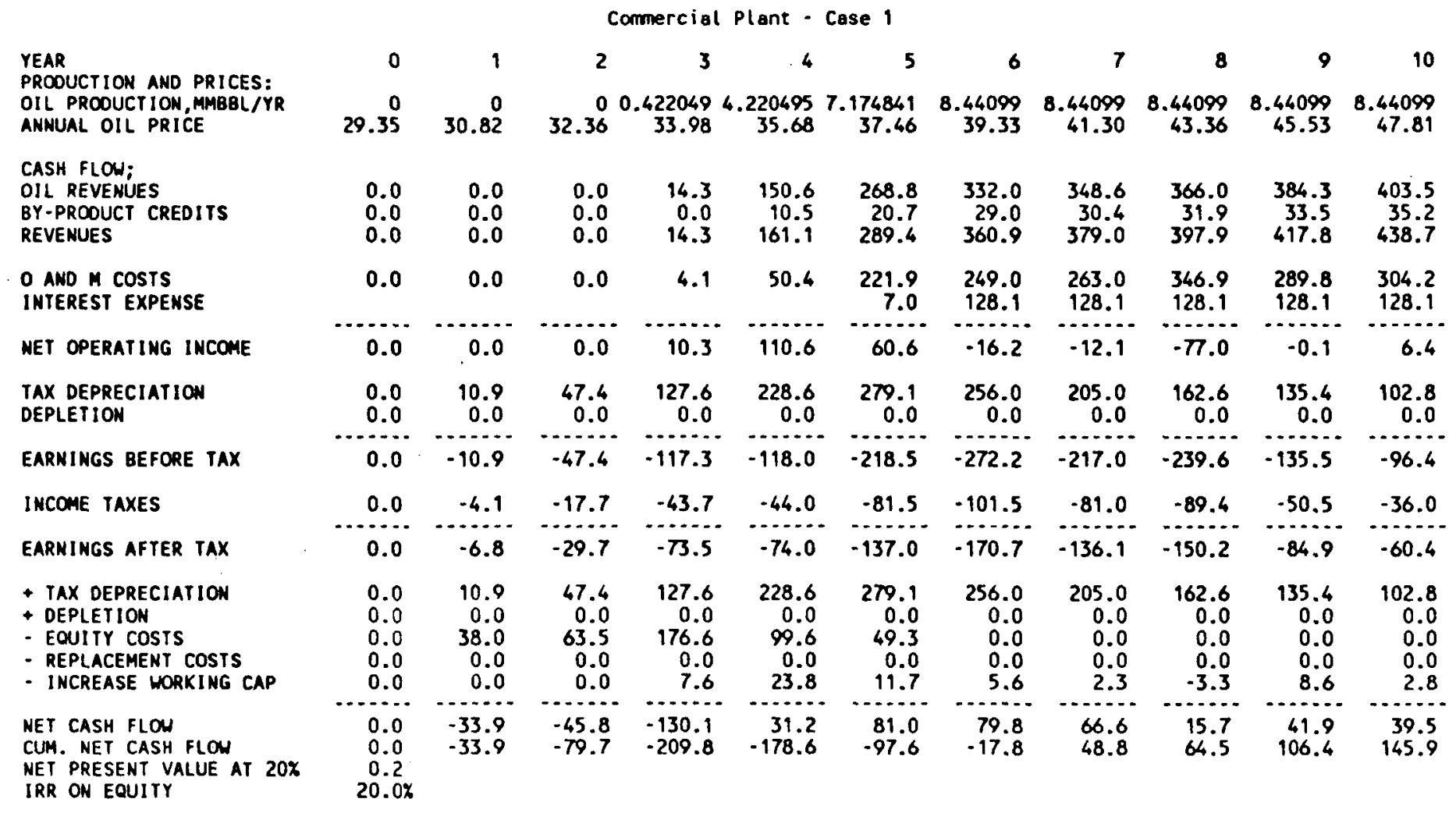


Table 6-1 (cont inued)

CASH FLON PROJECTIONS - OX REAL GROWTH

(s millions as spent)

Commercial Plant - Case 1

\begin{tabular}{|c|c|c|c|c|c|c|c|c|c|c|}
\hline $\begin{array}{l}\text { YEAR } \\
\text { PRCOUCTION ANO PRICES: } \\
\text { OIL PROOUCTION, MMBBL/YR } \\
\text { ANHUAL OIL PRICE }\end{array}$ & $\begin{array}{r}11 \\
8.44099 \\
50.20\end{array}$ & $\begin{array}{r}12 \\
8.44099 \\
52.71\end{array}$ & $\begin{array}{r}13 \\
8.44099 \\
55.34\end{array}$ & $\begin{array}{r}16 \\
8.44099 \\
58.11\end{array}$ & $\begin{array}{r}15 \\
8.44099 \\
61.02\end{array}$ & $\begin{array}{r}16 \\
8.44099 \\
64.07\end{array}$ & $\begin{array}{r}17 \\
8.44099 \\
67.27\end{array}$ & $\begin{array}{r}18 \\
8.44099 \\
70.63\end{array}$ & $\begin{array}{r}19 \\
8.44099 \\
74.17\end{array}$ & $\begin{array}{r}20 \\
8.44099 \\
77.87\end{array}$ \\
\hline $\begin{array}{l}\text { CASH FLOW; } \\
\text { OIL REVENUES } \\
\text { BY-PROOUCT CREDITS } \\
\text { REVENUES }\end{array}$ & $\begin{array}{r}423.7 \\
36.9 \\
460.7\end{array}$ & $\begin{array}{r}446.9 \\
38.8 \\
483.7\end{array}$ & $\begin{array}{r}467.2 \\
40.7 \\
507.9\end{array}$ & $\begin{array}{r}490.5 \\
42.8 \\
533.3\end{array}$ & $\begin{array}{r}515.0 \\
44.9 \\
560.0\end{array}$ & $\begin{array}{r}540.8 \\
47.2 \\
587.9\end{array}$ & $\begin{array}{r}567.8 \\
49.5 \\
617.3\end{array}$ & $\begin{array}{r}596.2 \\
52.0 \\
648.2\end{array}$ & $\begin{array}{r}626.0 \\
54.6 \\
680.6\end{array}$ & $\begin{array}{r}657.3 \\
57.3 \\
714.7\end{array}$ \\
\hline $\begin{array}{l}\text { AND } M \text { COSTS } \\
\text { NTEREST EXPENSE }\end{array}$ & & & & & & & & & & \\
\hline MET OPERATING INCOME & 13.2 & 20.3 & -62.6 & 35.6 & 43.9 & 52.6 & 61.6 & .44 .1 & 81.2 & 91.7 \\
\hline $\begin{array}{l}\text { TAX DEPRECIATION } \\
\text { DEPLETION }\end{array}$ & $\begin{array}{r}60.0 \\
0.0\end{array}$ & $\begin{array}{r}25.0 \\
0.0\end{array}$ & $\begin{array}{l}8.2 \\
0.0\end{array}$ & $\begin{array}{r}3.7 \\
12.8\end{array}$ & $\begin{array}{r}3.7 \\
16.1\end{array}$ & $\begin{array}{r}3.7 \\
19.5\end{array}$ & $\begin{array}{r}3.7 \\
23.2\end{array}$ & $\begin{array}{l}3.7 \\
0.0\end{array}$ & $\begin{array}{r}3.7 \\
39.0\end{array}$ & $\begin{array}{r}3.7 \\
35.2\end{array}$ \\
\hline EARNINGS BEFORE TAX & -46.8 & -4.7 & -70.7 & 19.2 & 24.1 & 29.3 & 34.8 & -47.8 & 46.5 & 52.8 \\
\hline INCOME TAXES & -17.5 & -1.7 & -26.4 & 7.1 & 9.0 & 10.9 & 13.0 & -17.8 & 17.3 & 19.7 \\
\hline EARNINGS AFTER TAX & -29.4 & -2.9 & -44.3 & 12.0 & 15.1 & 18.4 & 21.8 & -30.0 & 29.2 & 33.1 \\
\hline $\begin{array}{l}\text { + TAX DEPRECIATION } \\
+ \text { DEPLETION } \\
\text { - EOUITY COSTS } \\
\text { - REPLACEMENT COSTS } \\
\text { - INCREASE WORKING CAP }\end{array}$ & $\begin{array}{r}60.0 \\
0.0 \\
0.0 \\
0.0 \\
3.0\end{array}$ & $\begin{array}{l}25.0 \\
0.0 \\
0.0 \\
0.0 \\
3.1\end{array}$ & $\begin{array}{r}8.2 \\
0.0 \\
0.0 \\
0.0 \\
-4.3\end{array}$ & $\begin{array}{r}3.7 \\
12.8 \\
0.0 \\
0.0 \\
11.0\end{array}$ & $\begin{array}{r}3.7 \\
16.1 \\
0.0 \\
0.0 \\
3.6\end{array}$ & $\begin{array}{r}3.7 \\
19.5 \\
0.0 \\
0.0 \\
3.8\end{array}$ & $\begin{array}{r}3.7 \\
23.2 \\
0.0 \\
0.0 \\
4.0\end{array}$ & $\begin{array}{r}3.7 \\
0.0 \\
0.0 \\
0.0 \\
-5.4\end{array}$ & $\begin{array}{r}3.7 \\
31.0 \\
0.0 \\
0.0 \\
14.0\end{array}$ & $\begin{array}{r}3.7 \\
35.2 \\
0.0 \\
0.0 \\
4.6\end{array}$ \\
\hline $\begin{array}{l}\text { NET CASH FLOW } \\
\text { CUM. NEI CASH FLOW } \\
\text { NET PRESENT VALUE AT } 20 x \\
\text { IRR ON EQUITY }\end{array}$ & $\begin{array}{r}27.7 \\
173.6\end{array}$ & $\begin{array}{r}18.9 \\
192.5\end{array}$ & $\begin{array}{l}-31.9 \\
160.6\end{array}$ & $\begin{array}{r}17.5 \\
178.2\end{array}$ & $\begin{array}{r}31.3 \\
209.5\end{array}$ & $\begin{array}{r}37.8 \\
247.3\end{array}$ & $\begin{array}{r}44.7 \\
292.0\end{array}$ & $\begin{array}{r}-20.8 \\
271.2\end{array}$ & $\begin{array}{r}49.9 \\
321.1\end{array}$ & $\begin{array}{r}67.5 \\
388.6\end{array}$ \\
\hline
\end{tabular}


Table 6-1 (cont inued)

CASH FLOW PROJECTIONS - OX REAL GRONTH

(\$ millions as spent)

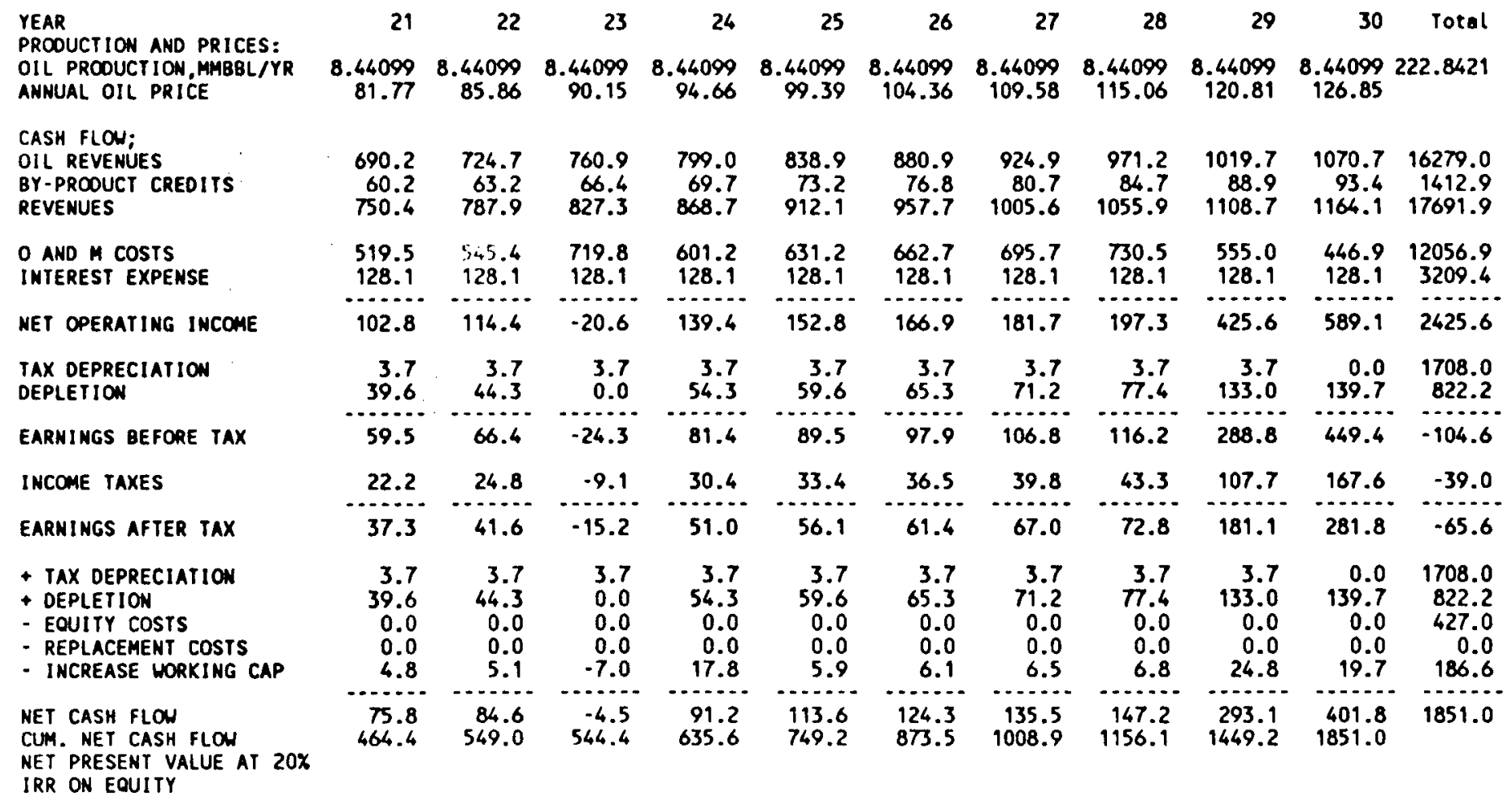


Table 6-2

CASH FLON PROJECTIONS - $2 \%$ REAL GROUTH

(s millions as spent)

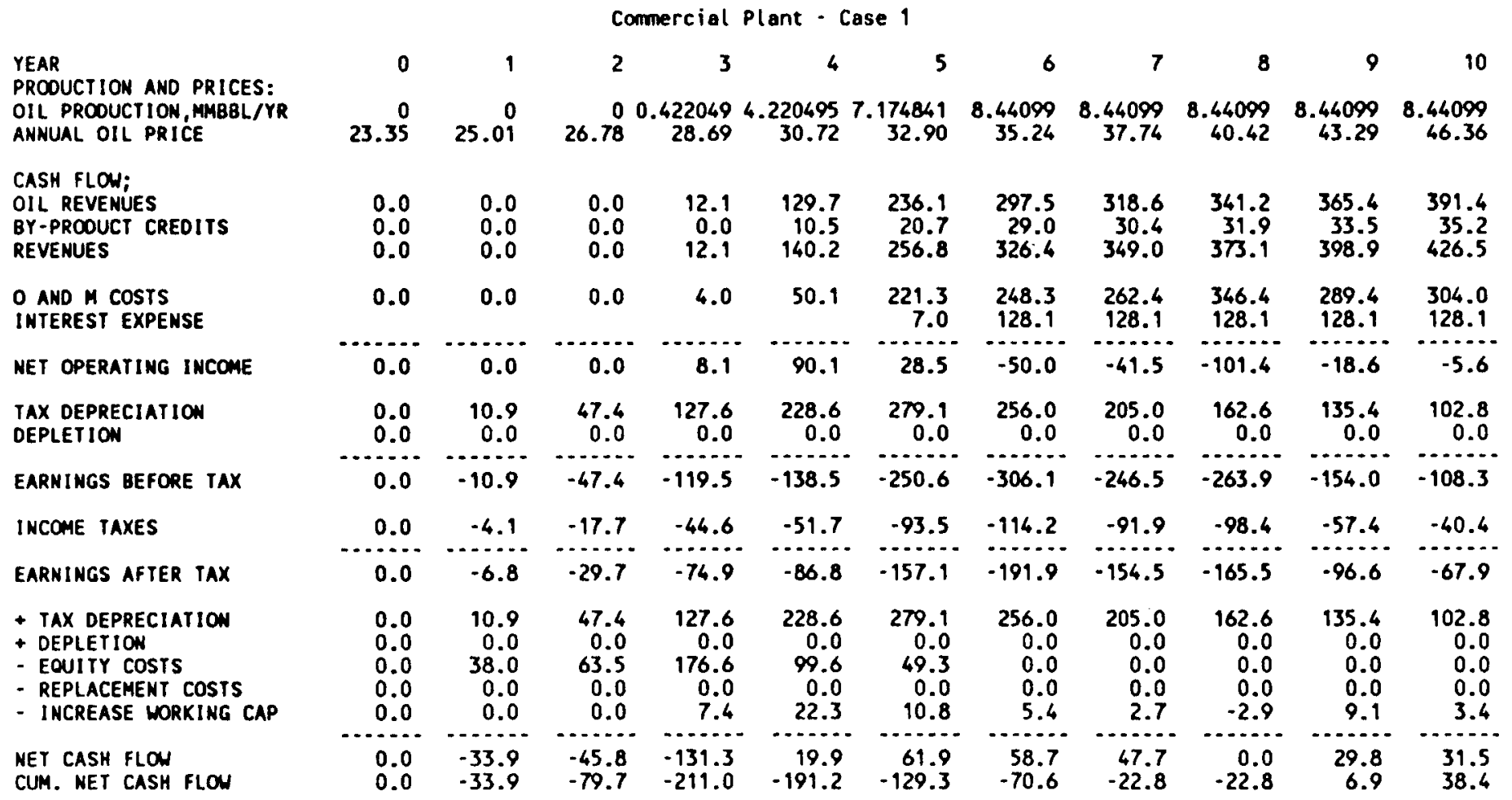


Table 6-2 (cont inued)

CASH FLOW PROJECTIONS - $2 X$ REAL GRONTH

(s millions as spent)

Commercial Plant - Case 1

\begin{tabular}{|c|c|c|c|c|c|c|c|c|c|c|}
\hline $\begin{array}{l}\text { YEAR } \\
\text { PROOUCTION AND PRICES: } \\
\text { OIL PROOUCTION, MMBBL/YR } \\
\text { ANNUAL OIL PRICE }\end{array}$ & $\begin{array}{r}8.44099 \\
49.66\end{array}$ & $\begin{array}{r}12 \\
8.44099 \\
53.18\end{array}$ & $\begin{array}{r}13 \\
8.44099 \\
56.96\end{array}$ & $\begin{array}{r}14 \\
8.44099 \\
61.00\end{array}$ & $\begin{array}{r}15 \\
8.44099 \\
65.33\end{array}$ & $\begin{array}{r}16 \\
8.44099 \\
69.97\end{array}$ & $\begin{array}{r}17 \\
8.44099 \\
74.94\end{array}$ & $\begin{array}{r}18 \\
8.44099 \\
80.26\end{array}$ & $\begin{array}{r}19 \\
8.44099 \\
85.96\end{array}$ & $\begin{array}{r}20 \\
8.44099 \\
92.06\end{array}$ \\
\hline $\begin{array}{l}\text { CASH FLOW; } \\
\text { OIL REVENUES } \\
\text { BY-PROOUCT CREDITS } \\
\text { REVENUES }\end{array}$ & $\begin{array}{r}419.1 \\
36.9 \\
456.1\end{array}$ & $\begin{array}{r}448.9 \\
38.8 \\
487.7\end{array}$ & $\begin{array}{r}480.8 \\
40.7 \\
521.5\end{array}$ & $\begin{array}{r}514.9 \\
42.8 \\
557.7\end{array}$ & $\begin{array}{r}551.5 \\
44.9 \\
596.4\end{array}$ & $\begin{array}{r}590.6 \\
47.2 \\
637.8\end{array}$ & $\begin{array}{r}632.6 \\
49.5 \\
682.1\end{array}$ & $\begin{array}{r}677.5 \\
52.0 \\
729.5\end{array}$ & $\begin{array}{r}725.6 \\
54.6 \\
780.2\end{array}$ & $\begin{array}{r}777.1 \\
57.3 \\
834.4\end{array}$ \\
\hline $\begin{array}{l}\text { O AND M COSTS } \\
\text { INTEREST EXPENSE }\end{array}$ & $\begin{array}{l}319.3 \\
128.1\end{array}$ & $\begin{array}{l}335.4 \\
128.1\end{array}$ & $\begin{array}{l}442.6 \\
128.1\end{array}$ & $\begin{array}{l}370.0 \\
128.1\end{array}$ & $\begin{array}{l}388.7 \\
128.1\end{array}$ & & & & & $\begin{array}{l}497.2 \\
128.1\end{array}$ \\
\hline NET OPERATING INCONE & 8.7 & 24.2 & -49.2 & 59.6 & 79.6 & 101.4 & 125.1 & 35.5 & 178.8 & 209.1 \\
\hline $\begin{array}{l}\text { TAX DEPRECIATION } \\
\text { DEPLETION }\end{array}$ & $\begin{array}{r}60.0 \\
0.0\end{array}$ & $\begin{array}{r}25.0 \\
0.0\end{array}$ & $\begin{array}{l}8.2 \\
0.0\end{array}$ & $\begin{array}{r}3.7 \\
22.3\end{array}$ & $\begin{array}{r}3.7 \\
30.4\end{array}$ & $\begin{array}{r}3.7 \\
39.1\end{array}$ & $\begin{array}{r}3.7 \\
48.6\end{array}$ & $\begin{array}{r}3.7 \\
12.7\end{array}$ & $\begin{array}{r}3.7 \\
70.0\end{array}$ & $\begin{array}{r}3.7 \\
82.2\end{array}$ \\
\hline EARNINGS BEFORE TAX & -51.3 & -0.8 & -57.4 & 33.5 & 45.5 & 58.6 & 72.8 & 19.1 & 105.1 & 123.3 \\
\hline INCOME TAXES & -19.1 & -0.3 & -21.4 & 12.5 & 17.0 & 21.9 & 27.2 & 7.1 & 39.2 & 46.0 \\
\hline EARNINGS AFTER TAX & -32.2 & -0.5 & -36.0 & 21.0 & 28.5 & 36.8 & 45.7 & 12.0 & 65.9 & 77.3 \\
\hline $\begin{array}{l}\text { + TAX DEPRECIATION } \\
\text { + DEPPLETION } \\
\text { - EQUITY COSTS } \\
\text { - REPLACEMENT COSTS } \\
\text { - INCREASE WORKING CAP }\end{array}$ & $\begin{array}{r}60.0 \\
0.0 \\
0.0 \\
0.0 \\
3.6 \\
\end{array}$ & $\begin{array}{r}25.0 \\
0.0 \\
0.0 \\
0.0 \\
3.8\end{array}$ & $\begin{array}{r}8.2 \\
0.0 \\
0.0 \\
0.0 \\
-3.5 \\
--1 .\end{array}$ & $\begin{array}{r}3.7 \\
22.3 \\
0.0 \\
0.0 \\
11.8\end{array}$ & $\begin{array}{r}3.7 \\
30.4 \\
0.0 \\
0.0 \\
4.6\end{array}$ & $\begin{array}{r}3.7 \\
39.9 \\
0.0 \\
0.0 \\
4.9\end{array}$ & $\begin{array}{r}3.7 \\
48.6 \\
0.0 \\
0.0 \\
5.2\end{array}$ & $\begin{array}{r}3.7 \\
12.7 \\
0.0 \\
0.0 \\
-4.1\end{array}$ & $\begin{array}{r}3.7 \\
70.0 \\
0.0 \\
0.0 \\
15.5\end{array}$ & $\begin{array}{r}3.7 \\
82.2 \\
0.0 \\
0.0 \\
6.2\end{array}$ \\
\hline $\begin{array}{l}\text { NET CASH FLOW } \\
\text { CUM. NEY CASH FLON } \\
\text { NET PRESENT VALUE AT } 20 X \\
\text { IRR ON EQUITY }\end{array}$ & $\begin{array}{l}24.3 \\
62.7\end{array}$ & $\begin{array}{l}20.7 \\
83.4\end{array}$ & $\begin{array}{r}-24.3 \\
59.1\end{array}$ & $\begin{array}{l}35.2 \\
94.3\end{array}$ & $\begin{array}{r}58.0 \\
152.3\end{array}$ & $\begin{array}{r}74.7 \\
227.0\end{array}$ & $\begin{array}{r}92.8 \\
319.8\end{array}$ & $\begin{array}{r}32.5 \\
352.3\end{array}$ & $\begin{array}{l}124.2 \\
476.4\end{array}$ & $\begin{array}{l}156.9 \\
633.4\end{array}$ \\
\hline
\end{tabular}

IRR ON EQUITY 
Table 6-2 (CONTINUED)

CASH FLOW PROJECTIONS - 2X REAL GRONTH

(S MILLIONS AS SPENT)

\begin{tabular}{|c|c|c|c|c|c|c|c|c|c|c|c|}
\hline $\begin{array}{l}\text { YEAR } \\
\text { PRODUCTION AND }\end{array}$ & 21 & 22 & 23 & 24 & 25 & 26 & 27 & 28 & 29 & 30 & Total \\
\hline $\begin{array}{l}\text { IL PROOUCTION, MMBBL/YR } \\
\text { NMUAL OIL PRICE }\end{array}$ & $\begin{array}{r}8.44099 \\
98.60\end{array}$ & $\begin{array}{r}8.64099 \\
105.60\end{array}$ & $\begin{array}{r}8.44099 \\
113.10\end{array}$ & $\begin{array}{r}8.44099 \\
121.13\end{array}$ & $\begin{array}{r}8.44099 \\
129.72\end{array}$ & $\begin{array}{r}8.44099 \\
138.94\end{array}$ & $\begin{array}{l}8.440 \\
148\end{array}$ & & 8.4 & $\begin{array}{l}8.440 \\
182\end{array}$ & 222.8421 \\
\hline $\begin{array}{l}\text { CASH FLON; } \\
\text { OIL REVENUES } \\
\text { BY-PROOUCT CREDITS } \\
\text { REVENUES }\end{array}$ & $\begin{array}{r}832.3 \\
60.2 \\
892.4\end{array}$ & $\begin{array}{r}891.4 \\
63.2 \\
954.5\end{array}$ & $\begin{array}{r}66.4 \\
1021.0\end{array}$ & $\begin{array}{r}69.7 \\
1092.1\end{array}$ & $\begin{array}{r}1095.0 \\
73.2 \\
1168.2\end{array}$ & $\begin{array}{r}1172 \\
76 \\
1249\end{array}$ & $\begin{array}{r}125 \\
8 \\
133\end{array}$ & $\begin{array}{r}84.7 \\
1429.9\end{array}$ & $\begin{array}{l}.7 \\
.9 \\
.6\end{array}$ & $\begin{array}{r}1543.0 \\
93.4 \\
1636.4\end{array}$ & $\begin{array}{r}19463.7 \\
1412.9 \\
20876.6\end{array}$ \\
\hline $\begin{array}{l}\text { O AND } ~ \\
\text { INTEREST COSTS EXPENSE }\end{array}$ & & & & & & & & & & $\begin{array}{l}456.2 \\
128.1\end{array}$ & \\
\hline NET OPERATING INCOME & 42.1 & 277.8 & 169.3 & 358.4 & 403.9 & 453.1 & 506.3 & 564.0 & 838.3 & 1052.1 & 5547.7 \\
\hline $\begin{array}{l}\text { TAX DEPR } \\
\text { DEPLET TO }\end{array}$ & 95 & $\begin{array}{r}3.7 \\
109.8\end{array}$ & $\begin{array}{r}3.7 \\
66.2\end{array}$ & $\begin{array}{r}3.7 \\
131.1 \\
0.1\end{array}$ & $\begin{array}{r}3.7 \\
140.2 \\
\end{array}$ & $\begin{array}{r}3.7 \\
149.9\end{array}$ & $\begin{array}{r}3.7 \\
160.4\end{array}$ & $\begin{array}{r}3.7 \\
171.6\end{array}$ & $\begin{array}{r}3.7 \\
183.6\end{array}$ & $\begin{array}{r}0.0 \\
196.4\end{array}$ & \\
\hline EARNINGS BEFORE TAX & 143.0 & 164.4 & 99,4 & 223 & 260.0 & 299.4 & 342.2 & 388.7 & 651.0 & 855.7 & 2130.1 \\
\hline INCOME TAXES & $\begin{array}{l}53.3 \\
-3 .\end{array}$ & 61.3 & 37.1 & 83.4 & 97.0 & 11 & 127 & 145.0 & 242.8 & 319.2 & 794.5 \\
\hline EARNINGS AFTER TAX & 89.7 & 103.1 & 62 & $40 ?$ & 163. & 187 & 214.6 & 243.7 & 408.2 & 536.5 & 1335.6 \\
\hline $\begin{array}{l}\text { - TAX DEPRECIATION } \\
\text { + DEPLETION } \\
\text { - EOUITY COSTS } \\
\text { - REPLACEMENT COSTS } \\
\text { - INCREASE WORKING CAP }\end{array}$ & $\begin{array}{r}3.7 \\
95.3 \\
0.0 \\
0.0 \\
6.6 \\
0 .\end{array}$ & $\begin{array}{r}3.7 \\
109.6 \\
0.0 \\
0.0 \\
7.1 \\
\ldots . . .\end{array}$ & $\begin{array}{r}3.7 \\
66.2 \\
0.0 \\
0.0 \\
-4.7\end{array}$ & $\begin{array}{r}3.7 \\
131.1 \\
0.0 \\
0.0 \\
20.3 \\
0 . .\end{array}$ & $\begin{array}{r}3.7 \\
140.2 \\
0.0 \\
0.0 \\
8.5 \\
. . .\end{array}$ & $\begin{array}{r}3.7 \\
149.9 \\
0.0 \\
0.0 \\
9.1 \\
.1\end{array}$ & $\begin{array}{r}3.7 \\
160.4 \\
0.0 \\
0.0 \\
0.7\end{array}$ & $\begin{array}{r}3.7 \\
179.6 \\
0.0 \\
0.0 \\
10.3 \\
\end{array}$ & $\begin{array}{r}3.7 \\
183.6 \\
0.0 \\
0.0 \\
28.6 \\
. .8\end{array}$ & $\begin{array}{r}0.0 \\
196.4 \\
0.0 \\
0.0 \\
23.9\end{array}$ & $\begin{array}{r}1708.0 \\
1709.6 \\
427.0 \\
0.0 \\
225.2\end{array}$ \\
\hline $\begin{array}{l}\text { NET CASH FLOW } \\
\text { CUM. NET CASH FLON } \\
\text { NET PRESENT VALUE AT } 2\end{array}$ & $\begin{array}{l}182.1 \\
815.5\end{array}$ & $\begin{array}{l}209 . \\
1024 .\end{array}$ & $\begin{array}{r}137.0 \\
1161.9\end{array}$ & $\begin{array}{r}254.7 \\
1416.6\end{array}$ & $\begin{aligned} 298.4 \\
1715.0\end{aligned}$ & $\begin{array}{r}332.3 \\
2047.3\end{array}$ & $\begin{array}{r}369.0 \\
2416.3\end{array}$ & $\begin{array}{r}408.7 \\
2825.0\end{array}$ & $\begin{array}{r}566.8 \\
3391.9\end{array}$ & $\begin{array}{r}709.0 \\
4100.9\end{array}$ & 4100.9 \\
\hline
\end{tabular}

NET PRESENT VALUE AT $20 X$
IRR ON EQUITY 
Table 6-3

CASH FLOW PROJECTIONS

( $\$$ millions as spent)

Demonstration Plant - Case 2

\begin{tabular}{|c|c|c|c|c|c|c|c|c|c|c|c|c|}
\hline $\begin{array}{l}\text { YEAR } \\
\text { PROOUCIION AND PRICES: } \\
\text { OIL PROOUCYION,MMBEL/YR } \\
\text { ANNUAL OIL PRICE }\end{array}$ & $\begin{array}{r}0 \\
0.00 \\
18.50\end{array}$ & $\begin{array}{r}1 \\
0.00 \\
19.43\end{array}$ & $\begin{array}{r}2 \\
0.00 \\
20.40\end{array}$ & $\begin{array}{r}3 \\
0.03 \\
21.42\end{array}$ & $\begin{array}{r}4 \\
0.62 \\
22.49\end{array}$ & $\begin{array}{r}5 \\
0.65 \\
23.61\end{array}$ & $\begin{array}{r}6 \\
0.65 \\
24.79\end{array}$ & $\begin{array}{r}7 \\
0.65 \\
26.03\end{array}$ & $\begin{array}{r}8 \\
0.65 \\
27.33\end{array}$ & $\begin{array}{r}9 \\
0.65 \\
28.70\end{array}$ & $\begin{array}{r}10 \\
0.65 \\
30.13\end{array}$ & $\begin{array}{r}\text { Total } \\
4.6\end{array}$ \\
\hline $\begin{array}{l}\text { CASH FLON; } \\
\text { OIL REVENUES } \\
\text { BY-PROOUCT CREDITS } \\
\text { REVENUES }\end{array}$ & $\begin{array}{l}0.0 \\
0.0 \\
0.0\end{array}$ & $\begin{array}{l}0.0 \\
0.0 \\
0.0\end{array}$ & $\begin{array}{l}0.0 \\
0.0 \\
0.0\end{array}$ & $\begin{array}{l}0.7 \\
0.6 \\
1.3\end{array}$ & $\begin{array}{l}14.0 \\
12.8 \\
26.7\end{array}$ & $\begin{array}{l}15.4 \\
14.1 \\
29.5\end{array}$ & $\begin{array}{l}16.2 \\
14.8 \\
31.0\end{array}$ & $\begin{array}{l}17.0 \\
15.6 \\
32.6\end{array}$ & $\begin{array}{l}17.9 \\
16.3 \\
34.2\end{array}$ & $\begin{array}{l}18.8 \\
17.2 \\
35.9\end{array}$ & $\begin{array}{l}19.7 \\
18.0 \\
37.7\end{array}$ & $\begin{array}{r}119.6 \\
109.4 \\
229.0 \\
0.0\end{array}$ \\
\hline $\begin{array}{l}\text { O AND M COSTS } \\
\text { INTEREST EXPENSE }\end{array}$ & $\begin{array}{r}0.0 \\
0.0 \\
\end{array}$ & $\begin{array}{l}0.0 \\
0.0 \\
-\end{array}$ & $\begin{array}{l}0.0 \\
0.0 \\
0\end{array}$ & $\begin{array}{r}8.9 \\
0.0 \\
\ldots \ldots\end{array}$ & $\begin{array}{r}42.3 \\
0.0 \\
\end{array}$ & $\begin{array}{r}42.7 \\
0.0 \\
\quad \ldots . .\end{array}$ & $\begin{array}{r}36.1 \\
0.0 \\
\ldots \ldots\end{array}$ & $\begin{array}{r}34.7 \\
0.0 \\
\ldots . .\end{array}$ & $\begin{array}{r}36.0 \\
0.0 \\
\ldots . . .\end{array}$ & $\begin{array}{r}36.6 \\
0.0 \\
\ldots . .\end{array}$ & $\begin{array}{r}38.0 \\
0.0 \\
\quad \ldots . .\end{array}$ & $\begin{array}{r}275.2 \\
0.0 \\
\end{array}$ \\
\hline NET OPERATING INCOME & 0.0 & 0.0 & 0.0 & .7 .6 & -15.5 & -13.2 & -5.0 & -2.2 & -1.8 & -0.7 & -0.3 & -46.3 \\
\hline $\begin{array}{l}\text { TAX DEPRECIATION } \\
\text { OEPLETION }\end{array}$ & $\begin{array}{r}0.0 \\
0.0 \\
0\end{array}$ & $\begin{array}{r}3.6 \\
0.0 \\
.0\end{array}$ & $\begin{array}{r}15.6 \\
0.0 \\
\quad\end{array}$ & $\begin{array}{r}35.3 \\
0.0 \\
\ldots .\end{array}$ & $\begin{array}{r}50.2 \\
0.0 \\
\end{array}$ & $\begin{array}{r}47.0 \\
0.0\end{array}$ & $\begin{array}{r}35.3 \\
0.0 \\
\ldots\end{array}$ & $\begin{array}{r}27.5 \\
0.0 \\
\end{array}$ & $\begin{array}{r}23.4 \\
0.0 \\
\end{array}$ & $\begin{array}{r}19.1 \\
0.0 \\
\end{array}$ & $\begin{array}{r}15.1 \\
0.0 \\
0 .\end{array}$ & $\begin{array}{r}272.2 \\
0.0 \\
\end{array}$ \\
\hline EARNINGS BEFORE TAX & 0.0 & -3.6 & -15.6 & -42.9 & -65.7 & -60.2 & -40.3 & -29.6 & -25.2 & -19.8 & -15.4 & -318.4 \\
\hline INCOME TAXES & 0.0 & -1.4 & -5.8 & -16.0 & -24.5 & -22.4 & -15.0 & -11.1 & -9.4 & -7.4 & -5.8 & $\begin{array}{l}-118.8 \\
-\ldots . .\end{array}$ \\
\hline EARHINGS AFTER TAX & 0.0 & -2.3 & -9.8 & -26.9 & -41.2 & -37.7 & -25.3 & -18.6 & -15.8 & -12.4 & -9.7 & -199.6 \\
\hline $\begin{array}{l}\text { + TAX DEPRECIATION } \\
\text { + DEPLETION } \\
\text { - EQUITY COSTS } \\
\text { - DEBT REPAYMENT } \\
\text { - REPLACEMENT COSIS } \\
\text { - INCREASE WORKING CAP }\end{array}$ & $\begin{array}{r}0.0 \\
0.0 \\
10.0 \\
0.0 \\
0.0 \\
0.0 \\
\cdots\end{array}$ & $\begin{array}{r}3.6 \\
0.0 \\
40.6 \\
0.0 \\
0.0 \\
0.0 \\
0\end{array}$ & $\begin{array}{r}15.6 \\
0.0 \\
80.5 \\
0.0 \\
0.0 \\
0.0 \\
\cdots\end{array}$ & $\begin{array}{r}35.3 \\
0.0 \\
126.8 \\
0.0 \\
0.0 \\
0.9 \\
\end{array}$ & $\begin{array}{r}50.2 \\
0.0 \\
14.8 \\
0.0 \\
0.0 \\
4.9 \\
-1.9\end{array}$ & $\begin{array}{r}47.0 \\
0.0 \\
0.0 \\
0.0 \\
0.0 \\
0.3 \\
0.3\end{array}$ & $\begin{array}{r}35.3 \\
0.0 \\
0.0 \\
0.0 \\
0.0 \\
-0.4 \\
-. . .\end{array}$ & $\begin{array}{r}27.5 \\
0.0 \\
0.0 \\
0.0 \\
0.0 \\
0.0 \\
0.0\end{array}$ & $\begin{array}{r}23.4 \\
0.0 \\
0.0 \\
0.0 \\
0.0 \\
0.2 \\
-\ldots . .\end{array}$ & $\begin{array}{r}19.1 \\
0.0 \\
0.0 \\
0.0 \\
0.0 \\
0.2 \\
0.2\end{array}$ & $\begin{array}{r}15.1 \\
0.0 \\
0.0 \\
0.0 \\
0.0 \\
0.3\end{array}$ & $\begin{array}{r}272.2 \\
0.0 \\
272.8 \\
0.0 \\
0.0 \\
6.3\end{array}$ \\
\hline $\begin{array}{l}\text { NET CASH FLOW } \\
\text { CUM. NET CASH FLOW }\end{array}$ & $\begin{array}{l}-10.0 \\
-10.0\end{array}$ & $\begin{array}{l}-39.3 \\
-49.3\end{array}$ & $\begin{array}{r}-74.7 \\
-124.0\end{array}$ & $\begin{array}{l}-119.3 \\
-243.3\end{array}$ & $\begin{array}{l}-10.7 \\
-254.0\end{array}$ & $\begin{array}{r}9.0 \\
-245.0\end{array}$ & $\begin{array}{r}10.4 \\
-234.6\end{array}$ & $\begin{array}{r}8.9 \\
-225.7\end{array}$ & $\begin{array}{r}7.4 \\
-218.3\end{array}$ & $\begin{array}{r}6.5 \\
-211.8\end{array}$ & $\begin{array}{r}5.2 \\
-206.6\end{array}$ & -206.6 \\
\hline
\end{tabular}


Tabte 6.4

CASH FLOW PROJECTIONS

(s millions as spent)

Demonstration Plant - Case $2 \mathrm{~A}$

\begin{tabular}{|c|c|c|c|c|c|c|c|c|c|c|c|c|}
\hline $\begin{array}{l}\text { YEAR } \\
\text { PRODUCTION AND PRICES: } \\
\text { OIL PRCOUCTION,MMBBL/YR } \\
\text { ANNUAL OIL PRICE }\end{array}$ & $\begin{array}{r}0 \\
0.00 \\
18.50\end{array}$ & $\begin{array}{r}1 \\
0.00 \\
19.43\end{array}$ & $\begin{array}{r}2 \\
0.00 \\
20.40\end{array}$ & $\begin{array}{r}3 \\
0.03 \\
21.42\end{array}$ & $\begin{array}{r}0.62 \\
22.49\end{array}$ & $\begin{array}{r}5 \\
0.65 \\
23.61\end{array}$ & $\begin{array}{r}6 \\
0.65 \\
24.79\end{array}$ & $\begin{array}{r}0.65 \\
26.03\end{array}$ & $\begin{array}{r}0.65 \\
27.33\end{array}$ & $\begin{array}{r}9 \\
0.65 \\
28.70\end{array}$ & $\begin{array}{r}10 \\
0.65 \\
30.13\end{array}$ & $\begin{array}{r}\text { Total } \\
4.6\end{array}$ \\
\hline $\begin{array}{l}\text { CASH FLOW; } \\
\text { OIL REVENUES } \\
\text { BY-PROOUCT CREDITS } \\
\text { REVENUES }\end{array}$ & $\begin{array}{l}0.0 \\
0.0 \\
0.0\end{array}$ & $\begin{array}{l}0.0 \\
0.0 \\
0.0\end{array}$ & $\begin{array}{l}0.0 \\
0.0 \\
0.0\end{array}$ & $\begin{array}{l}0.7 \\
0.1 \\
0.8\end{array}$ & $\begin{array}{r}14.0 \\
2.2 \\
16.2\end{array}$ & $\begin{array}{r}15.4 \\
2.4 \\
17.9\end{array}$ & $\begin{array}{r}16.2 \\
2.5 \\
18.7\end{array}$ & $\begin{array}{r}17.0 \\
2.7 \\
19.7\end{array}$ & $\begin{array}{r}17.9 \\
2.8 \\
20.7\end{array}$ & $\begin{array}{r}18.8 \\
3.0 \\
21.7\end{array}$ & $\begin{array}{r}19.7 \\
3.1 \\
22.8\end{array}$ & $\begin{array}{r}119.6 \\
18.8 \\
138.4 \\
0.0\end{array}$ \\
\hline $\begin{array}{l}\text { O AND M COSTS } \\
\text { INTEREST EXPENSE }\end{array}$ & $\begin{array}{l}0.0 \\
0.0\end{array}$ & $\begin{array}{l}0.0 \\
0.0\end{array}$ & $\begin{array}{l}0.0 \\
0.0\end{array}$ & $\begin{array}{l}6.5 \\
0.0\end{array}$ & $\begin{array}{r}37.0 \\
0.0\end{array}$ & $\begin{array}{r}37.9 \\
0.0\end{array}$ & $\begin{array}{r}32.2 \\
0.0\end{array}$ & $\begin{array}{r}32.4 \\
0.0\end{array}$ & $\begin{array}{r}29.6 \\
0.0\end{array}$ & $\begin{array}{r}29.9 \\
0.0\end{array}$ & $\begin{array}{r}31.0 \\
0.0\end{array}$ & $\begin{array}{r}236.6 \\
0.0\end{array}$ \\
\hline MET OPERATING INCOME & 0.0 & 0.0 & 0.0 & -5.7 & -20.8 & -20.1 & -13.5 & -12.7 & -8.9 & -8.2 & -8.2 & -98.1 \\
\hline $\begin{array}{l}\text { TAX DEPRECIATION } \\
\text { OEPLETION }\end{array}$ & $\begin{array}{l}0.0 \\
0.0\end{array}$ & $\begin{array}{l}3.4 \\
0.0\end{array}$ & $\begin{array}{r}14.7 \\
0.0\end{array}$ & $\begin{array}{r}33.3 \\
0.0\end{array}$ & $\begin{array}{r}47.3 \\
0.0\end{array}$ & $\begin{array}{r}44.4 \\
0.0\end{array}$ & $\begin{array}{r}33.3 \\
0.0\end{array}$ & $\begin{array}{r}25.9 \\
0.0\end{array}$ & $\begin{array}{r}22.1 \\
0.0\end{array}$ & $\begin{array}{r}18.1 \\
0.0\end{array}$ & $\begin{array}{r}14.3 \\
0.0\end{array}$ & $\begin{array}{r}256.8 \\
0.0\end{array}$ \\
\hline EARNINGS BEFORE TAX & 0.0 & -3.4 & -14.7 & -39.1 & -68.2 & -64.4 & -46.8 & -38.6 & -31.0 & -26.3 & -22.5 & -355.0 \\
\hline INCOME TAXES & 0.0 & -1.3 & -5.5 & .14 .6 & -25.4 & -24.0 & -17.4 & -14.4 & -11.6 & -9.8 & -8.4 & -132.4 \\
\hline EARNINGS AFTER TAX & 0.0 & -2.1 & -9.2 & -24.5 & -42.8 & -40.4 & -29.3 & -24.2 & -19.5 & -16.5 & -14.1 & -222.6 \\
\hline $\begin{array}{l}\text { + TAX DEPRECIATION } \\
\text { + DEPLETION } \\
\text { - EQUITY COSTS } \\
\text { - DEBT REPAYMENT } \\
\text { - REPLACEMENT COSTS } \\
\text { - INCREASE WORKING CAP }\end{array}$ & $\begin{array}{r}0.0 \\
0.0 \\
10.0 \\
0.0 \\
0.0 \\
0.0\end{array}$ & $\begin{array}{r}3.4 \\
0.0 \\
37.8 \\
0.0 \\
0.0 \\
0.0\end{array}$ & $\begin{array}{r}14.7 \\
0.0 \\
76.0 \\
0.0 \\
0.0 \\
0.0\end{array}$ & $\begin{array}{r}33.3 \\
0.0 \\
119.7 \\
0.0 \\
0.0 \\
0.6\end{array}$ & $\begin{array}{r}47.3 \\
0.0 \\
14.0 \\
0.0 \\
0.0 \\
3.8\end{array}$ & $\begin{array}{r}44.4 \\
0.0 \\
0.0 \\
0.0 \\
0.0 \\
0.2 \\
-.0\end{array}$ & $\begin{array}{r}33.3 \\
0.0 \\
0.0 \\
0.0 \\
0.0 \\
-0.4 \\
0 . .\end{array}$ & $\begin{array}{r}25.9 \\
0.0 \\
0.0 \\
0.0 \\
0.0 \\
0.1\end{array}$ & $\begin{array}{r}22.1 \\
0.0 \\
0.0 \\
0.0 \\
0.0 \\
-0.2 \\
-0 .\end{array}$ & $\begin{array}{r}18.1 \\
0.0 \\
0.0 \\
0.0 \\
0.0 \\
0.1\end{array}$ & $\begin{array}{r}14.3 \\
0.0 \\
0.0 \\
0.0 \\
0.0 \\
0.2\end{array}$ & $\begin{array}{r}256.8 \\
0.0 \\
257.4 \\
0.0 \\
0.0 \\
4.5\end{array}$ \\
\hline $\begin{array}{l}\text { NET CASH FLOW } \\
\text { CUM. NET CASH FLON }\end{array}$ & $\begin{array}{l}-10.0 \\
-10.0\end{array}$ & $\begin{array}{l}-36.5 \\
-46.5\end{array}$ & $\begin{array}{r}-70.5 \\
-117.0\end{array}$ & $\begin{array}{l}-111.5 \\
-228.5\end{array}$ & $\begin{array}{r}-13.2 \\
-241.7\end{array}$ & $\begin{array}{r}3.8 \\
-237.9\end{array}$ & $\begin{array}{r}4.4 \\
-233.6\end{array}$ & $\begin{array}{r}9.6 \\
-232.0\end{array}$ & $\begin{array}{r}2.8 \\
-229.2\end{array}$ & $\begin{array}{r}1.5 \\
-227.7\end{array}$ & $\begin{array}{r}0.0 \\
-227.7\end{array}$ & -227.7 \\
\hline
\end{tabular}


Table 6-5

CASH FLOW PROJECTIONS

(s millions as spent)

Pilot Plant - Case 3

\begin{tabular}{|c|c|c|c|c|c|c|c|c|c|c|c|c|}
\hline $\begin{array}{l}\text { YEAR. } \\
\text { PROOUCTION AND PRICES: } \\
\text { OIL PROOUCIION, MMBBL/YR } \\
\text { ANNUAL OIL PRICE }\end{array}$ & $\begin{array}{r}0 \\
0.00 \\
18.50\end{array}$ & $\begin{array}{r}1 \\
0.00 \\
19.43\end{array}$ & $\begin{array}{r}2 \\
0.00 \\
20.40\end{array}$ & $\begin{array}{r}3 \\
0.00 \\
21.42\end{array}$ & $\begin{array}{r}4 \\
0.00 \\
22.49\end{array}$ & $\begin{array}{r}5 \\
0.00 \\
23.61\end{array}$ & $\begin{array}{r}6 \\
0.00 \\
24.79\end{array}$ & $\begin{array}{r}7 \\
0.00 \\
26.03\end{array}$ & $\begin{array}{r}8 \\
0.00 \\
27.33\end{array}$ & $\begin{array}{r}9 \\
0.00 \\
28.70\end{array}$ & $\begin{array}{r}10 \\
0.00 \\
30.13\end{array}$ & $\begin{array}{r}\text { Total } \\
0.0\end{array}$ \\
\hline $\begin{array}{l}\text { CASH FLOW; } \\
\text { OIL REVENUES } \\
\text { BY-PROOUCT CREDITS } \\
\text { REVENUES }\end{array}$ & $\begin{array}{l}0.0 \\
0.0 \\
0.0\end{array}$ & $\begin{array}{l}0.0 \\
0.0 \\
0.0\end{array}$ & $\begin{array}{l}0.0 \\
0.0 \\
0.0\end{array}$ & $\begin{array}{l}0.0 \\
0.0 \\
0.0\end{array}$ & $\begin{array}{l}0.1 \\
0.0 \\
0.1\end{array}$ & $\begin{array}{l}0.0 \\
0.0 \\
0.0\end{array}$ & $\begin{array}{l}0.0 \\
0.0 \\
0.0\end{array}$ & $\begin{array}{l}0.0 \\
0.0 \\
0.0\end{array}$ & $\begin{array}{l}0.0 \\
0.0 \\
0.0\end{array}$ & $\begin{array}{l}0.0 \\
0.0 \\
0.0\end{array}$ & $\begin{array}{l}0.0 \\
0.0 \\
0.0\end{array}$ & \multirow{2}{*}{$\begin{array}{l}0.1 \\
0.0 \\
0.1 \\
0.0 \\
6.0 \\
0.0 \\
0.0\end{array}$} \\
\hline $\begin{array}{l}\text { O AND M COSTS } \\
\text { INTEREST EXPENSE }\end{array}$ & $\begin{array}{l}0.0 \\
0.0 \\
\ldots .\end{array}$ & $\begin{array}{l}0.0 \\
0.0\end{array}$ & $\begin{array}{l}0.0 \\
0.0\end{array}$ & $\begin{array}{l}0.0 \\
0.0\end{array}$ & $\begin{array}{l}6.0 \\
0.0\end{array}$ & $\begin{array}{l}0.0 \\
0.0\end{array}$ & $\begin{array}{l}0.0 \\
0.0\end{array}$ & $\begin{array}{l}0.0 \\
0.0\end{array}$ & $\begin{array}{l}0.0 \\
0.0\end{array}$ & $\begin{array}{l}0.0 \\
0.0\end{array}$ & $\begin{array}{l}0.0 \\
0.0\end{array}$ & \\
\hline NET OPERATING INCOME & 0.0 & 0.0 & 0.0 & 0.0 & -6.0 & 0.0 & 0.0 & 0.0 & 0.0 & 0.0 & 0.0 & -6.0 \\
\hline $\begin{array}{l}\text { TAX DEPRECIATION } \\
\text { OEPLETION }\end{array}$ & $\begin{array}{l}0.0 \\
0.0\end{array}$ & $\begin{array}{l}0.1 \\
0.0\end{array}$ & $\begin{array}{l}0.9 \\
0.0\end{array}$ & $\begin{array}{r}10.8 \\
0.0\end{array}$ & $\begin{array}{r}10.1 \\
0.0\end{array}$ & $\begin{array}{l}0.0 \\
0.0\end{array}$ & $\begin{array}{l}0.0 \\
0.0\end{array}$ & $\begin{array}{l}0.0 \\
0.0\end{array}$ & $\begin{array}{l}0.0 \\
0.0\end{array}$ & $\begin{array}{l}0.0 \\
0.0\end{array}$ & $\begin{array}{l}0.0 \\
0.0\end{array}$ & $\begin{array}{r}22.0 \\
0.0\end{array}$ \\
\hline EARNINGS BEFORE TAX & 0.0 & -0.1 & -0.9 & -10.8 & -16.0 & 0.0 & 0.0 & 0.0 & 0.0 & 0.0 & -0.0 & -27.9 \\
\hline INCOME TAXES & 0.0 & -0.1 & .0 .3 & -4.0 & -6.0 & 0.0 & 0.0 & 0.0 & 0.0 & 0.0 & -0.0 & -10.4 \\
\hline EARNINGS AFTER TAX & 0.0 & -0.1 & -0.6 & -6.8 & -10.0 & 0.0 & 0.0 & 0.0 & 0.0 & 0.0 & -0.0 & -17.5 \\
\hline $\begin{array}{l}\text { + TAX DEPRECIATION } \\
\text { + DEPLETION } \\
\text { - EQUITY COSTS } \\
\text { - DEBT REPAYMENT } \\
\text { - REPLACEMENT COSTS } \\
\text { - INCREASE WORKING CAP }\end{array}$ & $\begin{array}{l}0.0 \\
0.0 \\
0.0 \\
0.0 \\
0.0 \\
0.0 \\
0.0\end{array}$ & $\begin{array}{l}0.1 \\
0.0 \\
2.0 \\
0.0 \\
0.0 \\
0.0\end{array}$ & $\begin{array}{l}0.9 \\
0.0 \\
7.5 \\
0.0 \\
0.0 \\
0.0\end{array}$ & $\begin{array}{r}10.8 \\
0.0 \\
12.4 \\
0.0 \\
0.0 \\
0.0\end{array}$ & $\begin{array}{r}10.1 \\
0.0 \\
0.0 \\
0.0 \\
0.0 \\
0.5\end{array}$ & $\begin{array}{l}0.0 \\
0.0 \\
0.0 \\
0.0 \\
0.0 \\
0.0\end{array}$ & $\begin{array}{l}0.0 \\
0.0 \\
0.0 \\
0.0 \\
0.0 \\
0.0\end{array}$ & $\begin{array}{l}0.0 \\
0.0 \\
0.0 \\
0.0 \\
0.0 \\
0.0\end{array}$ & $\begin{array}{l}0.0 \\
0.0 \\
0.0 \\
0.0 \\
0.0 \\
0.0\end{array}$ & $\begin{array}{l}0.0 \\
0.0 \\
0.0 \\
0.0 \\
0.0 \\
0.0\end{array}$ & $\begin{array}{l}0.0 \\
0.0 \\
0.0 \\
0.0 \\
0.0 \\
0.0\end{array}$ & $\begin{array}{r}22.0 \\
0.0 \\
22.0 \\
0.0 \\
0.0 \\
0.5\end{array}$ \\
\hline $\begin{array}{l}\text { NET CASH FLOW } \\
\text { CUM. NET CASH FLOW }\end{array}$ & $\begin{array}{l}0.0 \\
0.0\end{array}$ & $\begin{array}{l}-2.0 \\
-2.0\end{array}$ & $\begin{array}{l}-7.2 \\
-9.2\end{array}$ & $\begin{array}{r}-8.4 \\
-17.5\end{array}$ & $\begin{array}{r}-0.5 \\
-18.0\end{array}$ & $\begin{array}{r}0.0 \\
-18.0\end{array}$ & $\begin{array}{r}0.0 \\
-18.0\end{array}$ & $\begin{array}{r}0.0 \\
-18.0\end{array}$ & $\begin{array}{r}0.0 \\
-18.0\end{array}$ & $\begin{array}{r}0.0 \\
-18.0\end{array}$ & $\begin{array}{r}0.0 \\
-18.0\end{array}$ & -18.0 \\
\hline
\end{tabular}


Figure 6-1

COMMERCIAL SHALE OIL ECONOMICS

IRR VS OIL PRICE - Case 1

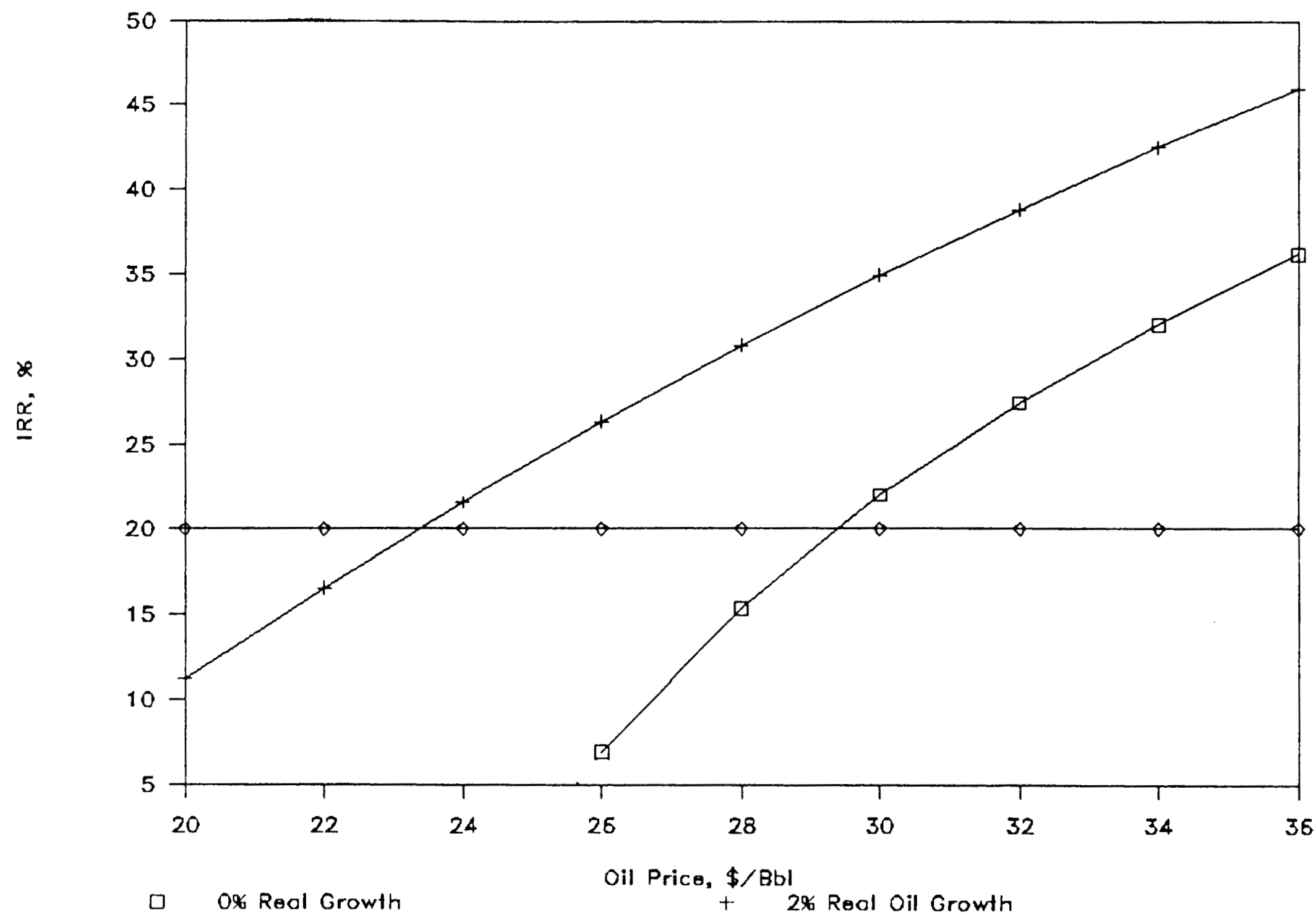




\section{PROJECT DESCRIPTION}

This section describes the mining system and the processing facilities that will be used to produce oil and by-products.

\section{SITE DESCRIPTION}

Federal Oil Shale Tract C-b is located in the Piceance Creek basin between the Colorado River on the south and the White River on the north. The basin is dominated by a large central plateau, which represents more than 75 percent of the basin's land surface. The area represents a sparsely populated portion of Rio Blanco County in northwestern Colorado. Terrain on the tract consists primarily of undulating valleys and ridges trending in a northeasterly direction and draining into Piceance Creek. The northern edge of the tract is approximately 0.5 mile south of Piceance Creek between Willow Creek and Stewart Gulch. West of the tract. Piceance Creek flows northwesterly approximately 24 miles to its confluence with the White River. Irrigated-grassland ranching predominates along Piceance Creek. The towns nearest the tract are Meeker (48 miles), Rifle (45 miles), and Rangely (65 miles).

The location of the tract relative to other existing and proposed oil shale projects in northwestern Colorado is shown in Figure 7-1. The tract, as legally described in U.S. Department of the Interior Oil Shale Lease C-20341, consists of 5,094 acres, more or less, which is shown in Figure 7-2 and is located in Rio Blanco County, Colorado, as follows:

T3S, R96W, 6th P.M.

Section $5, W 1 / 2$, SE $1 / 4$, and SW $1 / 4$

Section 6, lots 6 and $7, E 1 / 2$, SW $1 / 4$, and E 1/2

Section 7, lots $1,2,3$ and $4, E 1 / 2, W 1 / 2$, and $E 1 / 2$

Section 8, W 1/2, NE 1/4, NW 1/4, NW 1/4, and S $1 / 2$

Section 9, SW 1/4

Section 16, NW 1/4, and W 1/2, SW 1/4

Section 17

Section 18, lots 1, 2, 3, and 4, E 1/2, W 1/2, and E 1/2

T3S, R97W, 6th P.M.

Section $1, S 1 / 2$

Section 2, SE $1 / 4$

Section $11, E 1 / 2$ 
Section 12

Section 13, N $1 / 2$

Section 14, N 1/2, NE 1/4

\section{MINE PLAN}

\section{Typical MIS Retort Design}

Results of an extensive research and development program by Occidental at the Logan Wash Mine Site form the basis for the MIS retort design used in this study. A MIS mining isometric is shown in Figure 7-3.

The underground retort will be the basic production unit for the modified in-situ method. A retort will be a rectangular column of fragmented shale with a uniform particle size distribution. Each retort will be $165 \mathrm{ft}$. square by $270 \mathrm{ft}$. high. A retort will be created by:

- Mining void rooms.

A total of 23 percent of the overall retort volume will be removed by excavating shale from three separate levels; upper, intermediate, and lower. The mined rooms on the upper and lower levels will be $19 \mathrm{ft}$. high. On each of these levels, two pillars $17 \mathrm{ft}$. $\times 115 \mathrm{ft}$. will be left to support the roof. The excavated opening on the intermediate level will be $42 \mathrm{ft}$. high, with a central pillar 60 by $90 \mathrm{ft}$. left for support.

- Drilling Blastholes.

Vertical blastholes will be drilled into the retort block from the upper and intermediate void rooms. Horizontal blastholes will be drilled into the support pillars on the three levels.

- Rubblization.

All blastholes will be loaded with conventional explosives, or blasting agents primed with delay detonators, and stemmed. Rubblization of a retort will be a "one shot" sequential blast which will begin with the blasting of pillars followed by the explosive expansion of shale into void rooms.

Having created a retort, it will be ignited at the upper level, and burned by air injection so that the flame front moves slowly down through the permeable rubblized mass with the resulting gas and oil products flowing out at the haulage level. 
A retort contains 385,000 tons of retortable shale averaging 27 gallons per ton. Average yield of 80 percent is expected, giving a total yield of approximately 198,000 barrels per retort.

\section{General Mine Layout}

Mining activities can be divided into two categories: preproduction mining and production mining. Preproduction mining will include all the development and excavations within the mine pillar area. Production mining will include all mining outside the mine pillar.

The mine pillar will serve as a buffer zone from the possible influence resulting from mine subsidence. All shafts and all underground mine support facilities will be located within the mine pillar. Also included within the mine pillar will be the drifts and boreholes necessary for the off-gas handling system.

The production portion of the mine will be broken down into a system of panels. Each panel will contain a number of clusters. Panels will be accessed through a double-entry system of panel drifts. A cluster contains five retorts and will be the basic building block of the mine layout. The mining system will be an advancing system starting with the first cluster in the southern end of Panel 1 and working north. Adjacent panels will be developed in sequence until the western boundary is reached. Mining will progress from the mine pillar to the east and southeast according to expansion phase development plans.

There will be three major mining levels: upper void, intermediate void, and lower void. Shaft stations will be located on each level. Warehouse and shops will be located on the intermediate and lower levels. A system of ramps within the mine pillar will connect at all levels.

A system of ore passes and ventilation raises in the panels will provide ventilation paths between the mining levels and will provide for transfer of mined shale to the conveyor levels. All mined material is conveyed to the production shaft for hoisting.

\section{Overall Plot Plan}

The plot plan for the C-b tract is shown on Figure 7-4.

\section{GENERAL PROCESS FACILITY DESCRIPTION}

Case 1: The facilities include underground retorts and retort development; underground retorting, above ground MIS gas processing and compression; foul water stripping; surface shale 
processing, coal receiving, storage and handling of feed to the CFBC; CFBC/power generation; above ground retort facilities; oil upgrading facilities; and utilities/support facilities. The Case 1 facility will produce oil and excess power. Figure 7-5 and Table 7-1 show the arrangement of the process facilities for Case 1 and the material balance based on steady-state operation of twenty-two retorts burning simultaneously.

Case 2. The facilities include underground retorts and retort development; underground retorting, above ground MIS gas processing and compression; foul water stripping; surface shale processing, coal receiving, storage and handling of feed to the CFBC; CFBC/power generation; above ground retort facilities; and utilities/support facilities. The Case 2 facility will produce oil and excess power. Figure 7-6 and Table 7-2 show the arrangement of the process facilities for Case 2 and the material balance based on steady-state operation of two retorts burning simultaneously.

Case 3. The facilities include surface shale processing and the HRS above ground retort. Figure 7-7 and Table 7-3 show the arrangement of the process facilities for Case 3 and the material balance based on steady-state operation.

The units described in this section include:

- MIS Retort and Processing Facilities

- Mined Shale Handling and Processing

- CFBC/Power Generation

- Above Ground Retorting

- Oil Upgrading

- Syncrude Pipeline

- Utilities and Offsites

MIS Retorting and Processing Facilities

MIS retorting comprises the following operations:

- Underground retorting and oil recovery

- Off-gas processing to recover light oil from the gas and clean the gas of foul components 
- Otf-gas compression to draw the gas through the MIS retort and gas processing system and to overcome the backpressure of the boilers and other downstream systems

- Purification of foul water generated in off-gas processing

Underground Retorting. The MIS retorts operate in sequence. Once steady state is reached with two retorts in operation, a new retort will be started up and an exhausted retort will be shut down every 146 days. The exhausted retort, after shutdown, goes through a quench cycle that lasts roughly 10 months.

Retort Construction. Bulkheads must be constructed to isolate and seal individual retorts from adjacent retorts. Steel plate bulkheads reinforced with structural steel members are installed at all retort openings to the mine. The steel plates are welded to rock bolts installed on both sides and on top of the drift. The peripheral area between the plate, the side, and the top of the drift is shotcreted to provide the final air seal. Insulation is provided to protect the steel plate.

Ignition. The objective of the ignition phase is to establish a nearly uniform combustion zone across the whole retort. Ignition or startup of a retort requires the following actions:

- Purging the air (oxygen) from the retort rubble voids into the off-gas ducts in a safe manner

- Rapid and uniform heating of the top surface of the rubble column to the temperature at which combustion will occur, using hot inert gas

- Introducing air to initiate and establish the combustion zone

A retort is ignited every 14 days (Case 1). The hot inert gas generator (HIGG) will be used for ignition and pre-ignition to purge the retort of oxygen. The retort startup requires the HIGG to produce inert gas with an oxygen concentration less than 0.5 percent. The combined off-gas from all retorts will be maintained below the oxygen content of four percent during retort startup.

When the purge step is completed, the HIGG firing rate is increased. It takes approximately 18 hours to bring the surface of the rubble to the ignition temperature. At this point, excess air is introduced through the HIGG and combustion commences on the surface of the rubble. The plenum acts as a mixing zone, resulting in uniform temperatures over the surface of the rubble. 
Oil Production and Recovery. The shale oil will condense as it flows down through the rubblized shale. The liquid flows to the bottom of the retort and is collected inside the bulkhead at the product drift. The off-gas and liquid oil are drawn from the mined lower void level to a product collection drift.

The primary separation of the bulkhead oil and retort water occurs in the product drift behind the bulkhead. Bulkhead oil is pumped to the central compartment of the oil/water separator tank for further separation. A demulsifier is added to the suction of the oil/water pump or behind the bulkhead to promote oil/water separation.

Bulkhead oil from the oil/water separation tank is pumped to the retort oil tank on the surface. Retort water is utilized for retort bulkhead sprays and quench, or is pumped to the retort water tank on the surface.

The off-gas from each retort is piped to a collection system and ultimately to the off-gas raise to the surface processing facilities.

During the later stages of retorting, water recirculated from the surface facilities and from the bottom of the liquid pool behind the bulkhead compartment is sprayed into the vapor phase of the compartment behind the bulkhead. This permits cooling of the gas and allows retorting to go to completion to yield maximum recovery of oil.

Spent Retort Management. A retort contains over 100,000 MMBtu's of energy in hot spent shale at the end of the retorting cycle. This energy must be removed to prevent heat degradation of retort pillars. Water distributed over the top of the retort evaporates, cooling the retort and purifying the quench water which exits as a vapor. The water will be consumed by the water gas reaction, in calcium and magnesium slaking, and spent shale wetting. The water gas shift reaction occurs at high temperatures early in the quench phase. Slaking and wetting occur following the cooling of the shale to approximately $200^{\circ} \mathrm{F}$ at which point the water will react as a liquid.

The quench operation of each retort will last approximately 10 months. It will improve the off-gas heating value, clean process water, and complement the overall process water balance by consuming low-quality water.

Off-gas Processing. Processing of the MIS off-gas stream consists of (1) cooling the gas to remove water vapor and aerosol oil, (2) scrubbing it with stripped water to remove ammonia, (3) refrigerating and scrubbing it with a sponge oil to recover valuable 
hydrocarbon products and (4) compressing the gas to boiler feed pressure requirements.

The cleaned gas is burned in the CFBC. The ammoniated water is stripped of all volatile constituents and used elsewhere in the process.

Refrigeration is produced in an ammonia/water absorption system, utilizing low level heat in the form of 85 psig steam.

Cooling and Ammonia Recovery. Off-gas from the MIS retorts at $156^{\circ} \mathrm{F}$ and 8.5 psia enters near the bottom of the direct contact condenser, a tower with five contact sections; one spray and four packed. Cooled stripped water at $82^{\circ} \mathrm{F}$ is fed to the top of the second (from the bottom) 15-foot packed section where final traces of ammonia are removed from the MIS gas. The water flows downward to the first (lower) packed section where the main gas cooling and buik ammonia removal takes place. Heat removal is accomplished with a pump-around loop around this first packed section. Water vapor and some aerosol oil mist are condensed in this lower section.

Excess water and any oil from the pump-around loop at $120^{\circ} \mathrm{F}$ are sprayed into the bottom section of the tower which performs some cooling of the incoming gas stream and condenses the bulk of the aerosol oil. All oil and water from this spray section falls to the bottom of the tower where the two phases separate and flow to their respective compartments. The aqueous phase consisting of foul water is pumped to the foul water stripper unit. The oily phase is pumped to the aerosol settling tank where it is separated into water and oil phases.

Light Oil Recovery. The cleaned, cooled gas from the top of the second packed section enters the bottom of the third packed section, where it is further cooled to $50^{\circ} \mathrm{F}$ by a pump-around loop of refrigerated sponge oil. The pump-around loop is refrigerated to hold the bottom of the packed section temperature at $50^{\circ} \mathrm{F}$. Here some of the heavier hydrocarbons in the gas stream as well as additional water are condensed. The cooled gas stream enters the fourth (top) packed section countercurrent to a lean (regenerated) cold sponge oil stream which absorbs most of the $\mathrm{C5}+$ compounds. The lean sponge oil is composed of the heavier ends of the recovered hydrocarbons. The lean sponge oil feed is at $42^{\circ} \mathrm{F}$ to permit maintenance of the $50^{\circ} \mathrm{F}$ as it drops onto the third packed section thus providing some refrigeration to the pumparound loop. A withdrawal, equal to feed sponge oil plus absorbed hydrocarbons, is made from the warm end of the pump-around loop. 
Lean gas at $50^{\circ} \mathrm{F}$ and approximately 7.3 psia is sent to the off-gas compression unit.

The rich oil withdrawn from the pump-around loop is pumped through a coalescer, heated against lean sponge oil, and distilled in the sponge oil fractionator. A light naphtha overhead and lean oil bottom are produced in the fractionator. The former is stabilized by flashing to a slight vacuum. The flash gases are pumped to the MIS gas header. Most of the lean oil is recycled to the absorber as lean sponge oil, but a small fraction is withdrawn and combined with the stabilized naphtha overhead. The stream of hydrocarbons removed from the off-gas in the top two packed sections of the direct contact/condenser is combined with the oil recovered from the aerosol settling tank and the foul water stripper surge tank and is sent to the retort oil tank.

Foul water streams from the aerosol settling tank, coalescer and splitter overhead accumulator are combined with the water phase from the direct contact condenser and are sent to the foul water stripper.

A holding tank for all MIS oil is provided. This tank acts as a surge during outage of above ground processing facilities, and allows a constant feed rate to the OUG facilities.

The off-gas processing system will consist of a single train of equipment.

Off-gas Compression. Off-gas compressors draw the MIS gas through the retorts and processing equipment and compress it for use at the CFBC.

The system consists of two equally sized parallel centrifugal compressors with individual suction knockout drums. For reliability, one compressor is steam driven, the other motor driven.

Incoming gas at $50^{\circ} \mathrm{F}$ is compressed from 6.75 psia to $27 \mathrm{psia}$ and is delivered, without cooling, to the CFBC. Knockout condensate is pumped to the foul water surge tank in the foul water stripper unit. Antisurge recycle gas is returned for cooling to the direct contact condenser in the off-gas processing system.

The off-gas compression system maintains a slight vacuum at the top of the MIS retorts to permit the introduction of the required amount of air to each retort. The vacuum progressively increases toward the compressors. 
During operation, capacity regulation is accomplished by base loading the motor-driven (constant speed) compressor and modulating the speed of the turbine-driven compressor to maintain constant pressure at the off-gas entrance to the direct contact condenser. Manual valves at the lower bulkheads of each retort are adjusted to balance capacity between the retorts. Control valves at the upper bulkhead of each active retort regulate the air volumes to each retort.

During outage of the turbine-driven compressor, the suction of the motor-driven machine is throttled to maintain the controlled pressure.

On shutdown of one or both compressors, the air to the active retorts is shut off. This action immediately reduces gas production from all retorts to about 60 percent of normal. When only one compressor is shut down, there should be sufficient compressor capacity to handle the evolved gas; especially if immediate action is taken to increase the set point for the controlled pressure at the suction side of the direct contact condenser and to open all lower bulkhead valves.

Should both compressors shut down, the auxiliary engine-driven vent fan is started. This fan is necessary because the gas evolved from the retorts, when air to the retorts is off, will produce a pressure drop in the retort gas line to the surface greater than the natural draft. The fan will exhaust to the vent stack.

Foul Water Stripping. The foul water stripping section receives sour process condensate from the off-gas processing section including the direct contact condenser. The combined water is treated for oil and sludge removal and ammonia is stripped so that the water can be recirculated to the contact condenser and used elsewhere in the plant. Any excess stripped water is used for retort quench and ash wetting.

The foul water stream contains dissolved ammonia, carbon dioxide, and light organics with lesser quantities of hydrogen sulfide, carbon monoxide, and other contaminants, and will contain less than $10 \mathrm{ppm}$ of free oil. This stream is pumped from the foul water surge tank, heat exchanged with stripped water and fed to the top of the foul water stripper.

The overhead gas from the foul water stripper contains primarily $\mathrm{NH}_{3}, \mathrm{CO}_{2}$, light organics, and other contaminants. The gas is ultimately consumed in the CFBC, where the ammonia is converted to $\mathrm{N}_{2}$ and $\mathrm{H}_{2} \mathrm{O}$ and combustibles are burned. 
The stripped foul water from the bottom of the tower contains less than 50 ppmw of free ammonia. It is cooled by heat exchange with the feed and by air cooling to $120^{\circ} \mathrm{F}$, and is distributed for use as follows:

- As makeup absorption water to the upper section of the direct contact condenser after further cooling to $82^{\circ} \mathrm{F}$

- Other plant uses as required

To minimize steam usage, provisions are made to send foul water to the retort water tank without stripping.

The tank off-gas blower compresses vent gases collected from tank vents for disposal in the boiler fire box along with the foul gas.

\section{Mined Shale Handling and Processing}

The mined shale processing systems prepare shale for the AGR and CFBC and are shown on Figures 7-8 and 7-9.

Oil shale is mined and crushed to a nominal 8-inch lump size before being hoisted to the surface and discharged into the production headframe storage bin. The shale is drawn from the bin with an apron feeder and conveyor which transfers the shale to a live stockpile to maintain a four-day supply of feed to the shale preparation plant.

Coarse shale is reclaimed by belt feeders discharging to two primary crushers. Belt scales on the crusher feed conveyors weight the shale and, by means of a feedback circuit, set the rate of the belt feeders. Four belt feeders are provided, each capable of handling up to 50 percent of the required rate. A dust collection system controls fugitive dust.

Primary crusher feed conveyors deliver the coarse shale to two single-stage roll crushers. An electromagnet, installed on the discharge end of each conveyor, captures any tramp iron in the shale.

The roll crushers discharge to secondary crusher feed conveyors which feed the secondary crusher's surge bin. The shale is recovered from this surge bin via bottom vibratory feeders which feed the secondary crushers. Here shale is crushed to the nominal -1/4" $\times 0$ " required by the HRS above ground retort.

The final prepared material is conveyed to the HRS above ground retort. 
There is a 100 percent redundancy in all conveying and crushing equipment to assure the required stream factor for the boilers. The crushers are capable of much more feed than the normal conveyor carrying capacity to assure that they will not stall in the event of a sudden surge. The primary and secondary crusher buildings are insulated and heated to maintain a minimum temperature of $45^{\circ} \mathrm{F}$.

Coal Handling System. The coal handling system is required only for Cases 1 and 2. The coal handling system for Case 1 is shown on Figure 7-10. In view of the small quantity of coal used, coal delivery to the plant site will to be via trucks.

Trucks will discharge into a receiving hopper. The coal will be delivered from this hopper to a live storage site by belt conveyors. Coal will be reclaimed from this live storage site and delivered by belt conveyor to an intermediate storage hopper supplying the crushers.

The coal will be crushed to a nominal $-1 / 4$ " $X 0$ " size and delivered by belt conveyor to the boiler feed silo.

Feed to each conveyor system will be controlled with vibratory feeders. Magnetic separators to remove tramp iron will be installed at the head end of the conveyor feeding the 10-ton intermediate storage.

A dual 100 percent redundant conveying and crushing system will be used to assure continuous feed to the CFBC.

Dust collection, fire protection and ventilation requirements are provided. The crusher building will be heated and insulated to maintain a minimum temperature of $45^{\circ} \mathrm{F}$. The maximum temperature will be controlled by ventilation only.

\section{Steam/Power Generation Plant}

Circulating Fluid Bed Combustors (CFBC) will be used to burn the various forms of fuels available from the shale oil process plants, including raw shale. They produce process steam and power for the process and mining operations. Excess power will be sold to local utilities.

Five such units of essentially the same size are utilized in Case 1 to consume all the fuels that are available. Cases 2 and $2 \mathrm{~A}$ will each require one steam/power generation plant. 
CFBC fuels in Case 1,2 and 2A will consist of MIS gases, AGR spent shale, fuel gas and flue gas, and coal.

Circulating Fluid Bed Combustor. CFBC is a relatively new type of boiler and is used extensively for removal of $\mathrm{SO}_{2}$ by adsorption using lime or limestone. Thus, the need for expensive flue gas scrubbers is eliminated. In this application, shale will be the source of the alkaline minerals comparable to limestone. Flow diagrams of the CFBC/Power Plant are presented in Figures 7-11 and $7-12$.

The primary CFBC components are the combustion chamber, the hot cyclone collector, and the heat recovery section. Combustion and sulfur reactions take place in the combustion chamber which is usually of membrane waterwall welded panel construction. Fuel and other materials such as limestone or shale are fed into the lower combustion chamber. Primary air is blown through the flurdization grid plate to create a velocity sufficient to fluidize the bed. Dense fluidized system material is retained in the lower portion of the chamber, while the upper portion contains the entrained less-dense materials. This process gives the CFBC an excellent mixing characteristics. The less-dense system material is carried through the combustion chamber into the hot cyclone collector where most of the entrained material is separated from the hot gases. The former is reinjected into the combustion chamber through a nonmechanical seal. Hot flue gases leave the cyclone collector and enter a conventional boiler heat recovery section. From there the flue gas continues to a dust collection system, where the remaining entrained particles are removed to meet environmental requirements. The flue gas is then discharged to the stack via an induced-draft fan.

Combustion air is supplied by primary and secondary fans. The primary air is supplied below the fluidizing grid plate which forms the bottom of the combustion chamber. Secondary air is supplied at various levels in the lower portion of the combustion chamber. for staged combustion. This staged combustion process and the low combustion temperatures practically eliminate thermal $\mathrm{NO}_{x}$ formation. Secondary air is also ducted to the startup burners. High-pressure air is provided by a rotary positive displacement blower. This air is used to fluidize solids in the nonmechanical seal and return them to the lower combustion chamber. The design of the steam and water circuits associated with the CFBC system is similar to that of conventional boilers. Feedwater is supplied to the economizer, where it is heated before delivery to the steam drum. From the drum, the water is delivered via downcomers and headers to the combustion chamber membrane walls where it receives additional heat from the fluidized 
combustion reaction and is returned as a steam/water mixture to the steam drum. Depending on the type of fuel and steam conditions, a convective boiler bank section may also be required for the remaining evaporative duty not provided by the combustion chamber. All evaporative sections are arranged for natural circulation. Air preheater and superheater sections are included as required.

Solid fuels are typically conveyed to separate surge hoppers located adjacent to the boiler. From these surge hoppers, the fuels are fed to the boiler via appropriate feed systems and controls.

Bottom ash is removed from the lower part of the combustion chamber through a special nonmechanical device which classifies and cools the ash material. Fines are reinjected into the combustion chamber as required.

Since the combustion chamber temperature is well below the ash fusion point for most fuels, the need for waterwall soot blowers is eliminated. Due to the nature of the ash formed at these lower combustion temperatures, general soot blowing requirements are substantially less than in conventional boilers.

Each CFBC is capable of producing $380,000 \mathrm{lb} / \mathrm{hr}$ of steam at 1,300 psig and $955^{\circ} \mathrm{F}$. This steam will be expanded in conventional turbines having extraction provisions for process steam requirements. The turbine is capable of accepting full steam flow when process steam is not required. The turbine will exhaust to a surface condenser at 3.5 inch of mercury back pressure.

One of the primary advantages of using a CFBC for power/steam production is that it makes possible utilization of the spent shale for sulfur adsorption. In-situ adsorption of sulfur using limestone as the source of calcium is a well established technology. And although the use of spent shale has not been demonstrated on a large scale, preliminary indications from pilot plant tests conducted by the EPA are that this method is also effective.

A critical determinant of effectiveness is the ratio of calcium in the spent shale to sulfur in the fuel streams. The normal range for a typical CFBC burning coal with limestone as the sulfur adsorbent is a 2:1 to 3:1 molar ratio of $\mathrm{Ca}$ to $\mathrm{S}$. However, the EPA tests for shale were based on a molar ratio of 10:1. The calcium content of the spent shale from the HRS retort is as shown below:

$$
\text { calcite }\left[\mathrm{CaCO}_{3}\right] \text { content } \quad 9.2 \%
$$




$$
\text { dolomite }\left[\mathrm{CaMg}\left(\mathrm{CO}_{3}\right)_{2}\right] \text { content } \quad 7.0 \%
$$

Incorporating these data, Table 7-4 shows the molar ratio of calcium to sulfur for Case 1. The calcium in the form of calcite is known to be useful for sulfur capture, but the calcium in dolomite may not be as useful. The magnesium in dolomite is not useful for sulfur capture. The table shows the ratio for calcium from calcite alone as well as for calcium from both calcite and dolomite. Even after taking credit for the calcium in dolomite, the $\mathrm{Ca}$ to $\mathrm{S}$ ratio is still only slightly over 2 . Therefore, a very high reactivity rate is necessary for this quantity of shale to prove adequate. Ultimately, its effectiveness can only be established by testing. If testing proves that this ratio is inadequate, limestone will be required.

Table 7-5 shows the calcium to sulfur ratios for Case 2. As compared to Case 1, counteracting trends are evident. First, the scaled down MIS operation produces less off-gas requiring desulfurization, but it also produces less shale. While these two effects cancel each other, the increased quantity of coal requires more calcium. The net result is that limestone is required to maintain a sufficient calcium to sulfur ratio.

Case 2A is one-eleventh (1/11) of the size of Case 1 and the calcium to sulfur ratios would be proportionately the same as shown in Table 7-4, for Case 1.

The decision to use coal rather than raw shale for supplemental firing is based both on technical and economic factors. A major consideration is the effect on HRS oil production. Because any shale used as fuel would otherwise be fed to the HRS retort, using raw shale in the CFBC represents a significant loss of oil production capacity. In the commercial case, approximately 50 percent of the raw shale would have to be used as supplemental fuel. Futhermore, a reduced quantity of HRS fuel gas would be available to the CFBC. This would necessitate greater quantities of supplemental fuel to maintain flame stability.

At the same time, the MIS process is not affected by the choice of supplemental fuel. The low Btu MIS off-gas is the main reason supplemental firing is required. Therefore, the total heating value of fuel required for supplemental firing remains the same regardless of the type of fuel used because the MIS process is unaffected.

The heating value of raw shale is less than 25 percent that of coal. Therefore, even ignoring the loss of HRS fuel gas mentioned above, the amount of supplemental fuel required would be four 
times as much using raw shale. Raw shale would have to be much cheaper than coal to make that option economically viable.

The CFBC material balances for Cases 1,2, and 2A are presented in Tables 7-6, 7-7, and 7-8, respectively.

\section{Above ground Retorting and Processing}

The AGR plant performs the following operations:

- Retorting

- Retort effluent quenching

- Deashing

- Recycle gas separation

- Spent shale processing

The material balances for Cases 1, 2/2A, and 3, for the HRS above ground retort are presented in Tables 7-9, 7-10, and 7-11, respectively.

Hot-Recycled-Solids Retorting. Raw shale together with hotrecycled-solids pass by gravity and in plug flow through the Pyrolyzer. Oil vapor and gas liberated from the shale pass radially across the Pyrolyzer and are collected and removed at several points along the Pyrolyzer for downstream processing. The pyrolyzed shale is conveyed pneumatically through an Air Lift Combustor to a Classifier where the hot solids disengage from the flue gases. The hot solids fall from the Classifier through a Delayed Fall Combustor, then through a Fluidized Bed Combustor (FBC). At this point, essentially all combustibles have been burned from the shale. Removal of spent shale from the FBC is regulated to maintain the proper level in the FBC. The hot recycled solids from the FBC are combined with raw shale in a Fluid Bed Mixer before entering the Pyrolyzer. The rate of raw shale addition is varied to maintain the desired temperature in the Pyrolyzer.

Secondary air for the Circulating Fluidized Bed Combustor (CFBC) is used to convey spent shale pneumatically to the CFBC.

There is a single HRS retort in each of the cases in the study. Each retort is sized to process the design raw shale feed rate.

Case

Feed Rate (tons/stream/day)

$\begin{array}{rcr}1 & 2 \& 2 A & 3 \\ 12,800 & 1,000 & 100\end{array}$


A diagram of the HRS retort is shown on Figure 7-13.

Retort Effluent Quenching. As shown on Figure 7-14, reactor effluent consisting of recycle gas and pyrolysis product flows to a high temperature quench tower where it is cooled by pump-around streams. The tower contains disk and doughnut trays to minimize holdup of solids contained in the feed. The overhead goes to a low temperature quench tower where it also is cooled by a pumparound stream. Again, disk and doughnut trays are used.

The degree of separation in these towers is admittedly low, however the heaviest fraction contained in the overhead from the low temperature quench tower will be a light naphtha which will separate readily from water condensed from the overhead. The separator following the overhead condenser will be provided with a baffle and level and interface controls so that sour water and naphtha are recovered separately.

Deashing. As shown on Figure 7-14, the bottom product streams from the two quench towers are cooled to $280^{\circ} \mathrm{F}$. The naphtha stream is heated to $280^{\circ} \mathrm{F}$. Process water in the amount of about 10 percent by weight of the total hydrocarbon is heated to $280^{\circ} \mathrm{F}$ under sufficient pressure to prevent boiling. These streams are all combined and passed through a mixing device to cause intimate contact between the oil and the water. Prior to mixing, an appropriate additive is added to the water to allow such vigorous mixing with minimum formation of a stable emulsion. The combined stream goes to a separator where dirty water (containing fine particles of shale carried over in the retort effluent) is separated from deashed oil. The separator drum will have provision for the intermittent removal of any emulsion at the oilwater interface.

The emulsion removal system treats any persistent emulsion from the deasher. Any emulsion formed is routed to the deasher emulsion tanks. The emulsion is mixed with an emulsion-breaking chemical and heated in the tanks. After phase separation, the oil phase is drawn off, cooled and returned to the deashing section. The water phase, containing some shale fines, is pumped to the spent shale cooling system.

Recycle Gas Separation. As shown on Figure 7-14, the gas stream from the low temperature quench separator drum goes through a knockout drum on its way to a compressor where it is compressed to 33.5 psia. The compressed gas is divided into a product gas stream and a recycle stream. The product gas is 
used as plant fuel. The recycle gas is heated in a furnace to $1000^{\circ} \mathrm{F}$ on its way to the retort.

Spent Shale Processing. In Cases 1,2, and 2A, the spent shale is carried pneumatically by secondary air from the spent shale lock hopper on the HRS retort to the CFBC. The spent shale ultimately becomes a part of the ash from the CFBC.

In Case 3, the spent shale is carried pneumatically to a baghouse. En route, the shale is cooled by means of water sprays in the transfer line (see Figure 7-15). The maximum allowable temperature to the baghouse is about $300^{\circ} \mathrm{F}$. If additional cooling is required beyond that attained in the transfer line, a vortex type of mixer may be added between the line and the baghouse. In this case, a shale-water slurry would be produced in addition to dry shale from the baghouse. The flue gases from the retort are cooled in a similar manner on their way to the baghouse.

\section{Oil Upgrading.}

Before processing in most conventional refineries, raw shale oil must be fractionated and pretreated to remove excess nitrogen and arsenic and to lower the pour point of the oil.

Union Oil Company's proprietary upgrading technology is used in this study. The raw shale oil is subjected to severe hydrotreatment to remove arsenic, nitrogen, and sulfur. Process operations include hydrotreating, hydrogen production, and recovery of sulfur and anhydrous ammonia.

Fractionation. The primary purpose of the fractionation unit is to produce a shale oil suitable for storage and further processing.

Deashed oil is preheated to $400^{\circ} \mathrm{F}$. The hot feed passes through a pressure control valve which maintains a back pressure on the upstream equipment sufficient to prevent flashing. The feed then enters the fractionation unit. The overhead vapors are partially condensed and cooled in the fractionator overhead condenser and collected in the reflux accumulator, where vapor liquid separation takes place. The condensed liquids include all of the water contained in the fractionator feed.

The water settles out in the accumulator boot and is pumped to the sour water treating unit. The net vapor stream from the reflux accumulator is compressed and fed to the debutanizer.

The fractionator reboil heat is provided by a pump-through reboiler. The reboiler heating medium is hot oil circulated from a fired 
heater. The net bottoms from the fractionation unit are cooled in a heat exchange train which includes the fractionator feed/bottoms exchanger, the product oil/crude shale oil preheat exchanger (in the deashing area), and the shale oil product cooler and are then sent to the hydrotreating unit.

The net overhead liquid from the fractionator reflux accumulator is preheated to $300^{\circ} \mathrm{F}$ in the debutanizer feed/bottoms exchanger, and fed to the debutanizer. The debutanizer overhead vapors are cooled and condensed in the overhead condenser. The noncondensible vapor stream containing all the gases and a very small amount of $\mathrm{C5}+$ material is sent to the fuel gas system. All of the overhead condensate is refluxed to the debutanizer.. There is no net overhead hydrocarbon liquid produced. The small amount of water in the feed to the debutanizer is collected overhead, condensed, and settles out in the reflux accumulator. It is combined with the sour water from the fractionator reflux accumulator and sent to the sour water treating unit. The debutanizer bottoms are combined with the partially cooled, stabilized shale oil from the fractionator (bottoms), further cooled with the fractionator bottom stream and are sent to the hydrotreating unit.

Hydrotreating Unit. The hydrotreating unit accomplishes two important processing steps: dearseniting/pretreating and hydrotreating. The dearseniting/pretreating section treats deashed shale oil to remove arsenic, particulates and metals. This section also hydrogenates mono-olefins, diolefins, and other compounds in the oil which could cause catalyst bed fouling and catalyst deactivation in the downstream treating section. The dearseniter/pretreater also converts some sulfur, nitrogen, and oxygen compounds in the oil to hydrogen sulfide, ammonia, and water. The hydrotreating/hydrocracking section reduces nitrogen and sulfur and improves viscosity and pour point of the shale oil.

Dearseniting/Pretreater. Deashed shale oil is pumped from raw oil tankage to the pretreating feed drum. The oil feed from the surge drum mixes with cold recycle gas and the mixture is preheated by exchange with hot reactor effluent. The preheated recycle gas and oil then flow to the fired process heater and are heated to reaction temperature. The oil and gas mixture flows from the fired heater to a series of fixed bed reactors in which the oil is filtered, dearsenited, and mildly hydrotreated.

There are three parts to the reactor section of the dearseniter/pretreater. The first consists of the guard reactors which are filled with inerts that have a high capacity for holding particulates while minimizing plugging. These guard reactors are 
designed to prevent plugging in the downstream reactors by filtering out ash and particulates components that were not removed in the upstream deashing unit. The second part of the reactor section contains the dearseniting reactors which are filled with an absorbent that removes arsenic from the oil. The last part of the reactor section contains the pretreating reactor designed to stabilize the oil and remove any compounds that would cause catalyst bed fouling of the hydrotreating/ hydrocracking section.

Effluent from the final reactor is cooled by exchange with the reactor charge and flows to a hot separator where it flashes to produce an overhead vapor and a bottoms liquid product. The liquid stream is routed directly to the hydrotreating feed surge drum. The overhead vapor from the hot separator is cooled and further flashed in the cold separator. The vapor from this separator is compressed and recycled back to the reactors. The liquid phase is combined with the liquid from the hot separator and is routed to the hydrotreating feed surge drum.

Hydrotreating/Hydrocracking. The hydrotreating/hydrocracking section processes shale oil that has been filtered, dearsenited, and mildly hydrotreated in an upstream dearseniting/pretreating unit. The hydrotreating/hydrocracking section is designed to severely hydrotreat the oil to substantially reduce its nitrogen content and improve viscosity and pour point characteristics.

Dearsenited oil from the hot and cold separators of the dearseniting/pretreating section flows into the hydrotreating feed surge drum. The shale oil feed from the surge drum is preheated by exchange with the product stabilizer bottoms and the hot reactor effluent. The heated feed is combined with heated hydrotreater recycle gas and injected into the first hydrotreating reactor. Cool recycle gas is injected into selected locations in the reactor beds to absorb the heat of reaction, thereby, holding bed temperatures to predetermined levels.

The effluent from the bottom of the first reactor is passed to the second and third reactors, respectively. Cold recycle gas is likewise injected into selected locations of the second and third reactor to absorb heat of reaction and limit temperature rise. Hot effluent from the third reactor is passed through the feed and recycle gas preheaters to cool and condense oil. The cooled product is phase separated. The vapor phase (unreacted hydrogen) is scrubbed, combined with makeup hydrogen, and recompressed for recycle. The liquid phase is flashed to remove volatile constituents and fed to the stabilizer reboiler. The resultant gases from flashing are washed to remove foul constituents and 
sent to sour gas treating. The resultant foul water is sent to foul water treating.

The stabilizer is a distillation operation used to remove most of the light constituents from the treated oil, thereby, lowering the vapor pressure. Reboil heat is obtained from the third reactor effluent (part of the cooling train for the effluent). Reflux consists of condensate generated from the flash operations prior to feeding the stabilizer. The light overheads are combined with other sour gases and sent to sour gas treating. The bottom is cooled and constitutes the hydrotreated products.

Hydrogen Unit. The hydrogen unit uses natural gas as a feed stock to produce hydrogen for use in the hydrotreating unit.

Natural gas is compressed from 45 psig to 433 psig by the firstand second-stage compressor and heated to $700^{\circ} \mathrm{F}$ in a feed preheat exchanger. The gas is then passed through a cobalt-moly bed and a zinc oxide bed to remove trace amounts of hydrogen sulfide or mercaptans. Steam is added to the treated feed gas and the mixture is heated and partially reformed. The partially reformed gas is cooled in the waste heat boiler and reformed further in a high-temperature shift converter.

The reformed mixture is cooled in the boiler feedwater/product gas exchanger and the resulting two-phase mixture is separated in the first condensate knockout drum. The liquid, being relatively pure water, is sent to the stripping section of the deaerator. The vapor is cooled to $110^{\circ} \mathrm{F}$ in the product cooler, and the two-phase mixture is separated in the second condensate knockout drum. The liquid is stripped of carbon dioxide in the decarbonator, and also sent to the stripping section of the dearator.

The vapor from the drum is sent to the pressure swing adsorbers (PSA) for purification into the hydrogen product. The hydrogen is filtered in the hydrogen product filter and is sent to the hydrotreating unit. The purge gas from the pressure swing adsorbers is used as fuel in the reformer furnace.

The steam system in the hydrogen unit is designed to handle the steam requirements of the entire OUG facilities. The system consists of a deaerator, high-pressure boiler feedwater pumps, reformer waste heat boiler feedwater pumps, and condensate pumps.

Sour Water and Sour Gas Treating Unit. The sour water treating unit removes ammonia and hydrogen sulfide. It produces anhydrous ammonia from sour water generated by the quenching 
of hydrogen recycle gas in the hydrotreating unit, from that produced in the AGR unit, and from sour water from the OUG sulfur recovery unit. The combined sour water stream is steam stripped to remove hydrogen sulfide and ammonia. The stripped water is recycled to the hydrotreating unit quenching process. The sour gases from the sour water stripper overhead are then routed to a proprietary process, the Phosam-W process. In the Phosam-W process, the ammonia is removed from these sour gases by absorbing with a lean phosphoric acid solution. The ammonia-free sour gas is then routed to the OUG sulfur recovery unit for $\mathrm{H}_{2} \mathrm{~S}$ removal.

The rich phosphoric acid (ammonium phosphate) is heated, whereupon, the ammonium phosphate decomposes into ammonia and phosphoric acid. The regenerated phosphoric acid is recycled and the ammonia recovered as anhydrous ammonia for sale.

Syncrude Pipeline

The syncrude pipeline is a 46-mile pipeline to connect the plant site with an existing Chevron Oil crude oil network at Rangely, Colorado. One pump station, located at the plant site, is provided. The pipeline capacity is a nominal 700 GPM.

Utilities

Electrical System. The electrical systems provided for the power generation plant include:

- Main generator step-up transformer (13.8KV/345KV)

- Normal station service transformer (13.8 KV/4160V)

- Station auxiliary power transformers (345KV/4160V)

- 4160 switchgear

- 480V MCC 
- Lighting

- Communication

These systems provide power to the plant for oil shale processes and for sale to the local utilities.

Plant Auxiliaries. Plant auxiliaries include auxiliary steam and boiler feedwater.

Auxiliary Steam. Auxiliary steam will be required for startup and for certain services while the CFBC is down for repairs or inspection. This auxiliary steam will be generated by a packaged oil fired boiler. The capacity will be $150,000 \mathrm{lb} / \mathrm{hr}$ at $350 \mathrm{psig}$.

Boiler Feedwater. Boiler feedwater treatment will consist of mixed resin bed demineralizers. A single $100 \mathrm{gpm}$ train will be provided for each bciler. Each demineralizer will have its own chemical injection system.

\section{UTILITY REQUIREMENTS}

The utility requirements for Cases $1,2 / 2 A$ and 3 are shown in Tables $7-12,7-13$, and $7-14$, respectively.

The CFBC will generate all power and steam requirements in Cases 1 and 2. Where there is excess power, it will be sold. Power for Case 3 is available from local utilities.

The power for the cooling water system and plant and instrument air supply is included in the utilities and offsite section.

Power requirements were derived by summing equipment brake horsepower quantities. The brake horsepower values were those calculated in sizing specific equipment.

An item of concern is the amount of raw water required for each of the cases. This large quantity is primarily for cooling tower makeup. The large cooling water load is caused by the high heat rejection in the steam turbine condensers. The quantity of cooling water required will be minimized by using air cooling to the extent possible. This will be determined in the design phase.

\section{CATALYST AND CHEMICAL CONSUMPTION}

The catalyst and chemical consumption for Cases 1,2 and 2A are shown in Tables 7-15 and 7-16, respectively. 
Table 7-1

OVERALl Material balance - CASE 1

COMMERCIAL PLANT

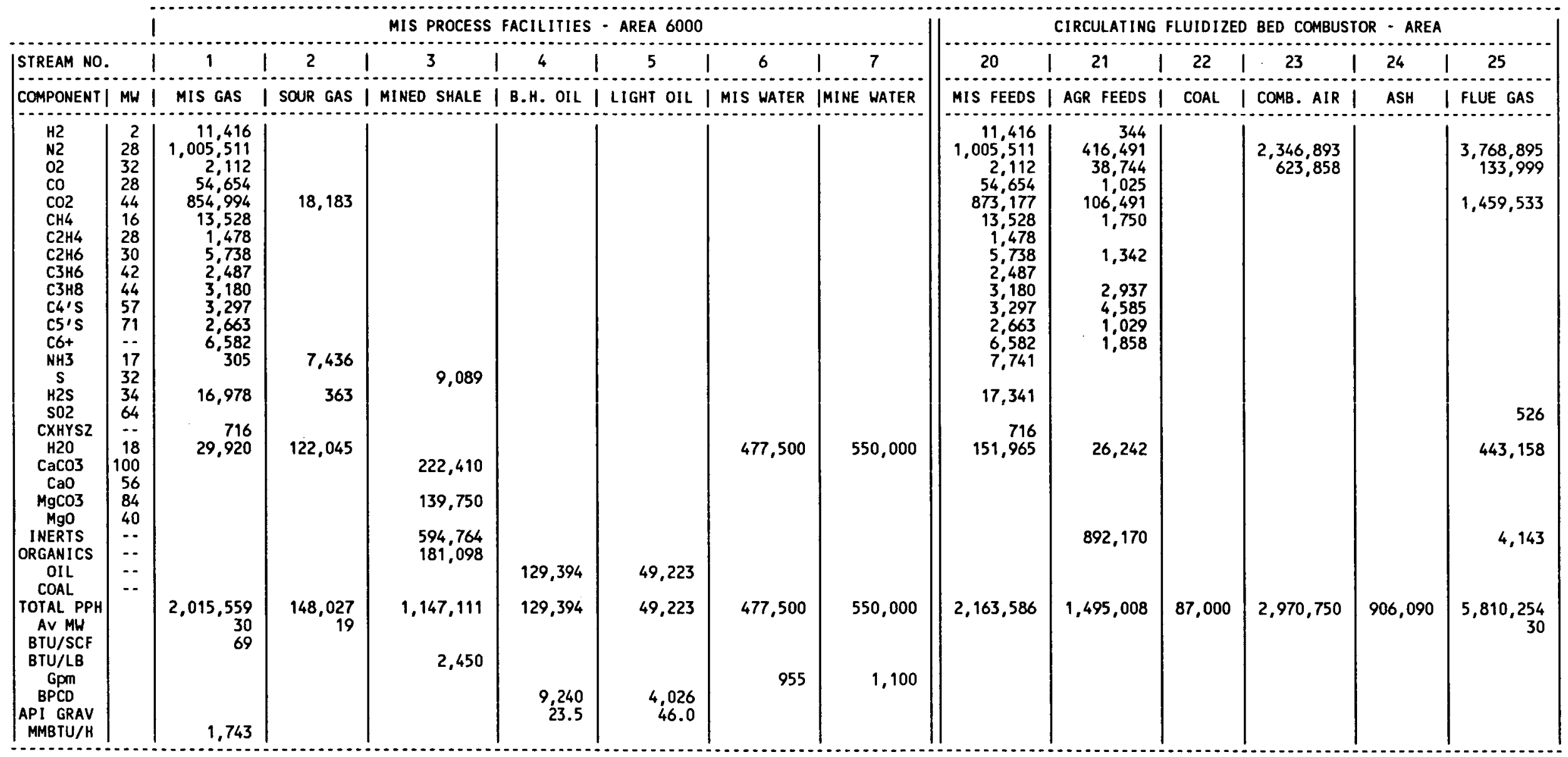


Table 7-1 (CONTINUED)

OVERALL MATERIAL baLANCE - CASE 1

COMMERCIAL PLANT

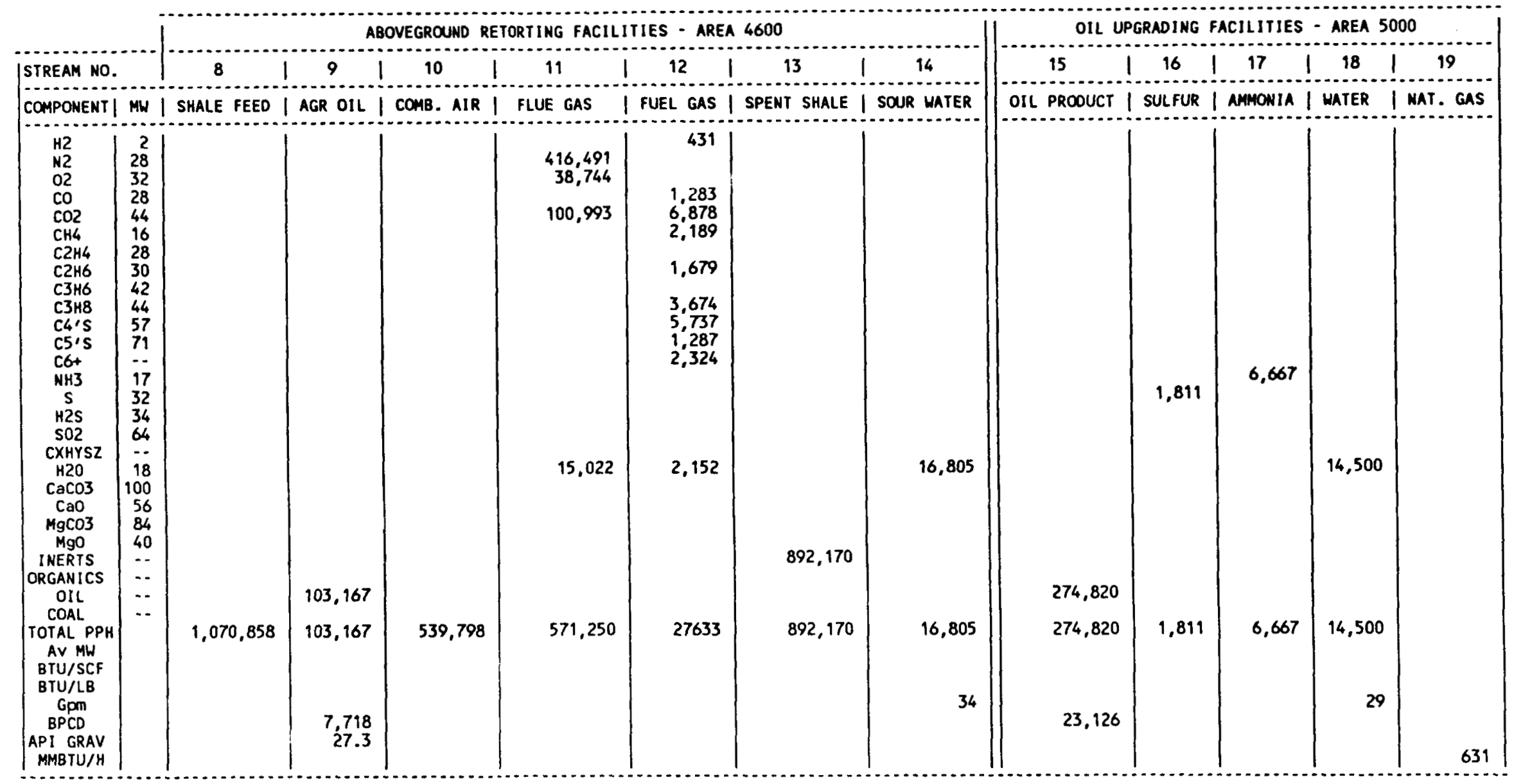


Table 7-2

OVERALl material balanCe - CASE 2

DEMONSTRATION PLANT

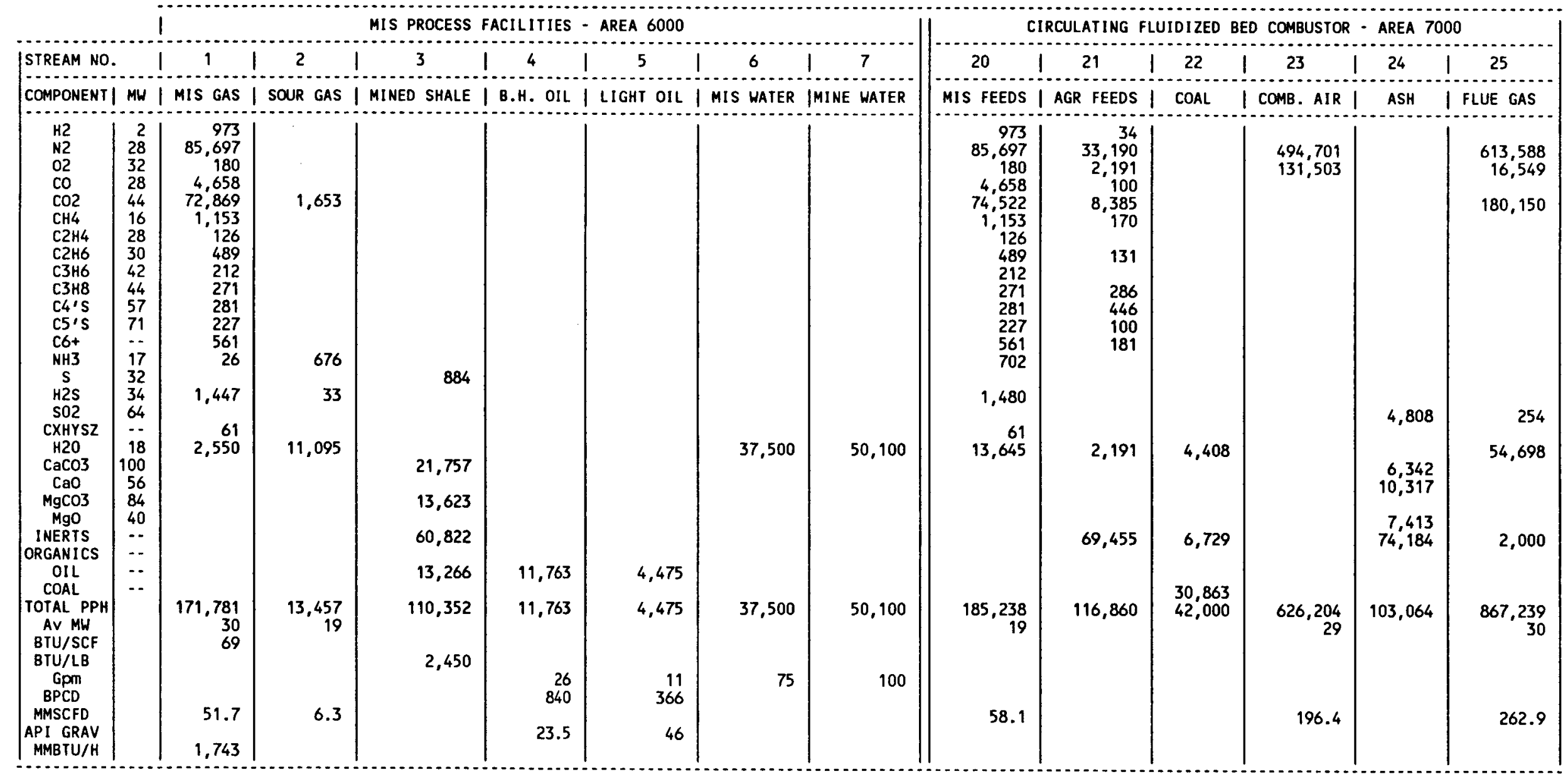


Table $7-2$ (Continued)

OVERALL MATERIAL BALANCE - CASE 2

DEMONSTRATION PLANT

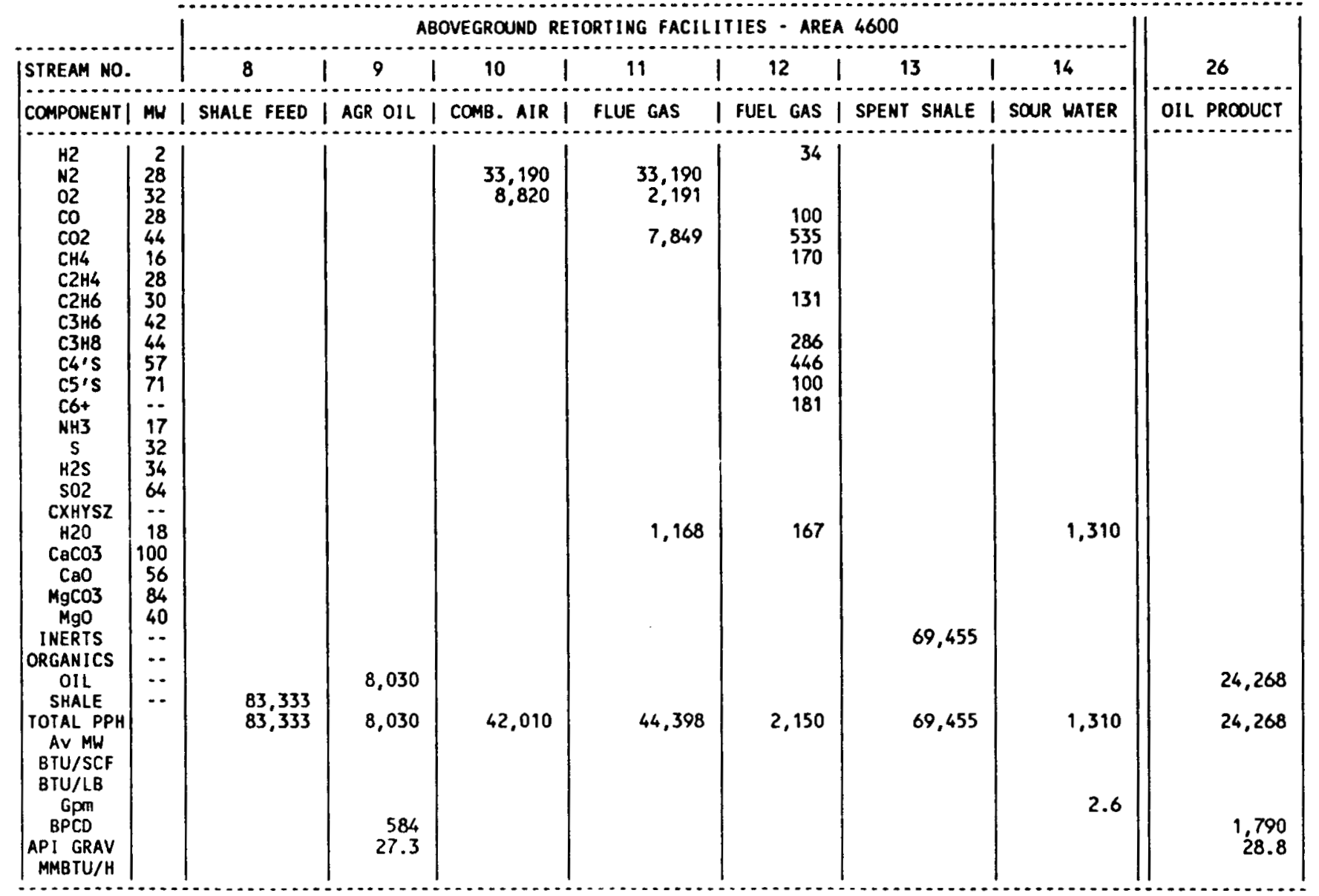


Table 7-3

overall material balance - case 3

PILOT PLANT

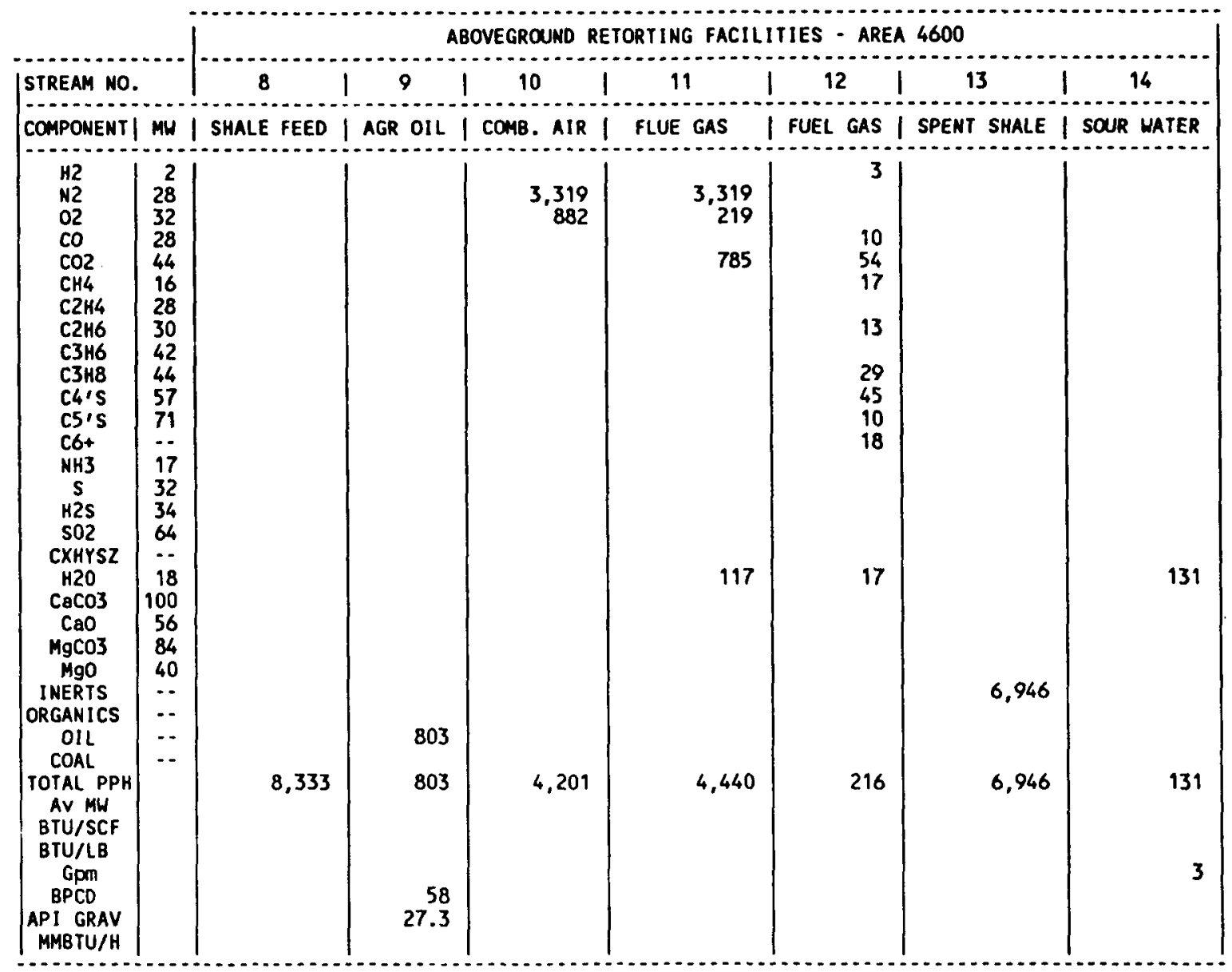


Table 7-4

CALCIUM/SULFUR MOLAR RATIOS

CASE 1

STREAM

SPENT SHALE

HRS FLUE GAS

PLUS SHALE fines

HRS DIRTY WATER

INCLUDES SHALE finES

HRS FUEL GAS

MIS SQUR GAS

MIS OFFGAS

SUPPLEMENTAL COAL

\section{TOTAL}

MOLAR RATIO

RAW SHALE REQU'D FOR MOLAR RATIO OF (ASSUMING DOLOMITE IS NOT EFFECTIVE)

0 Btu/lb

2,570 TPSD

0 Btu/lb

127 TPSD

$0 \mathrm{Btu} / \mathrm{lb}$

13 TPSD

265 TPSD

1,776 TPSD

$0 \mathrm{Btu} / \mathrm{Lb}$

24, 187 TPSD

1,044 TPSD

\section{SULFUR CONTENT}

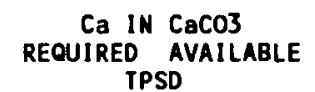

\section{PLUS Ca IN}

AVAILABLE

PLUS Mg IN

AVAILABLE

$$
\begin{aligned}
8,123 \mathrm{TPSD} \\
0 \mathrm{Btu} / \mathrm{Lb}
\end{aligned}
$$

26.3 $13,200 \mathrm{Btu} / \mathrm{lb}$

$864 \mathrm{Btu} / \mathrm{lb}$

$10,300 \mathrm{Btu} / \mathrm{Lb}$
0.034 IPSO

negl.

4 TPSD

204 TPSD H2S

192.0 TPSD Sulfur 240.0

$0.5 \times$ SULFUR

5.22 TPSD

6.5
536

170
286.1

\section{5}

1.38

588.8

705.9

$\begin{array}{lll}2 & \text { WHICH IS } & 2,128 \text { TPSO } \\ 3 & \text { WHICH IS } & 5,534 \text { TPSD }\end{array}$ 
Table 7-5

CALCIUM/SULFUR MOLAR RATIOS CASE 2

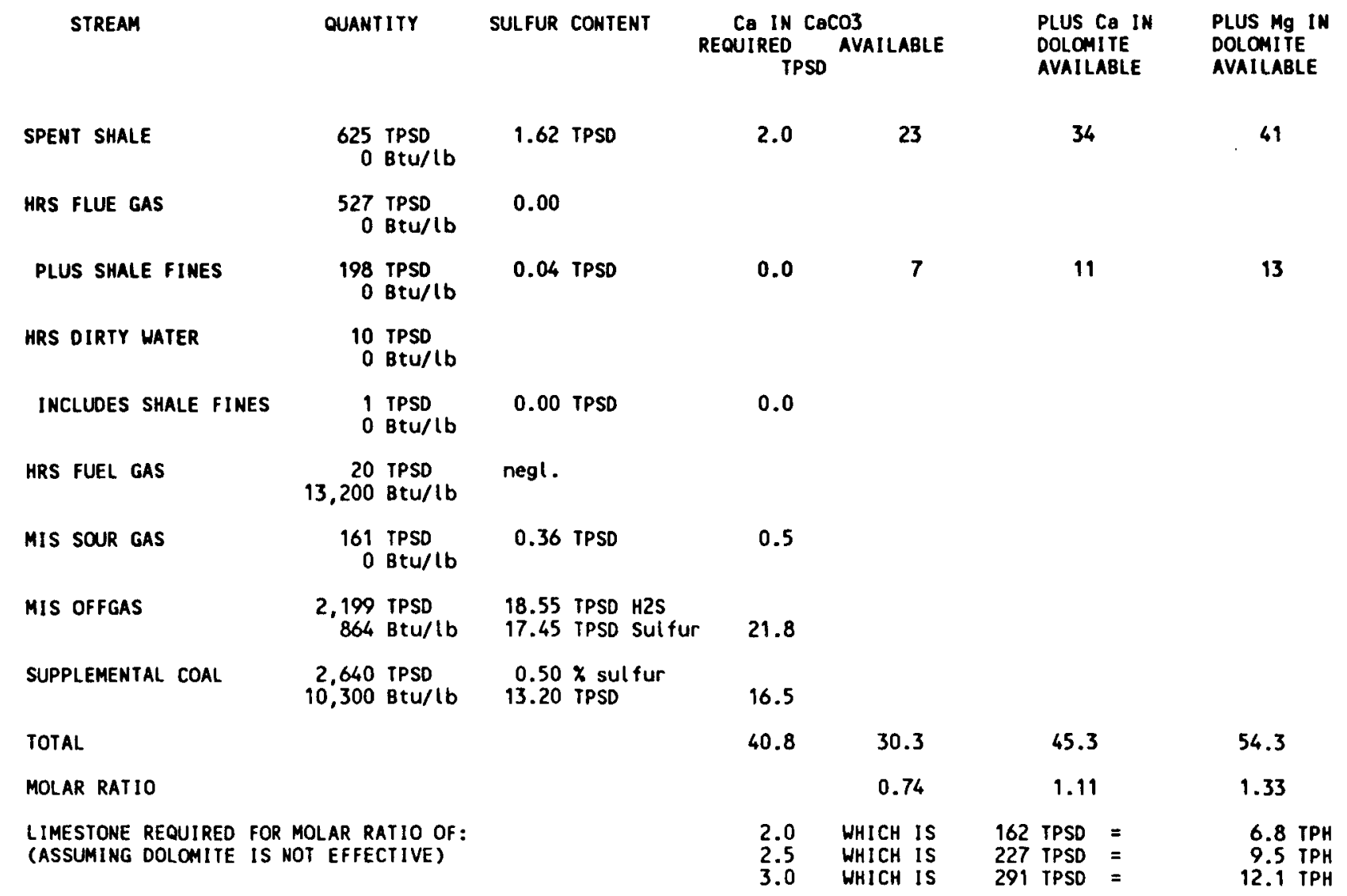


Table 7-6

CFBC

\section{MATERIAL/UTILITY BALANCE \\ Case 1}

ITEM TOTAL PER BOILER

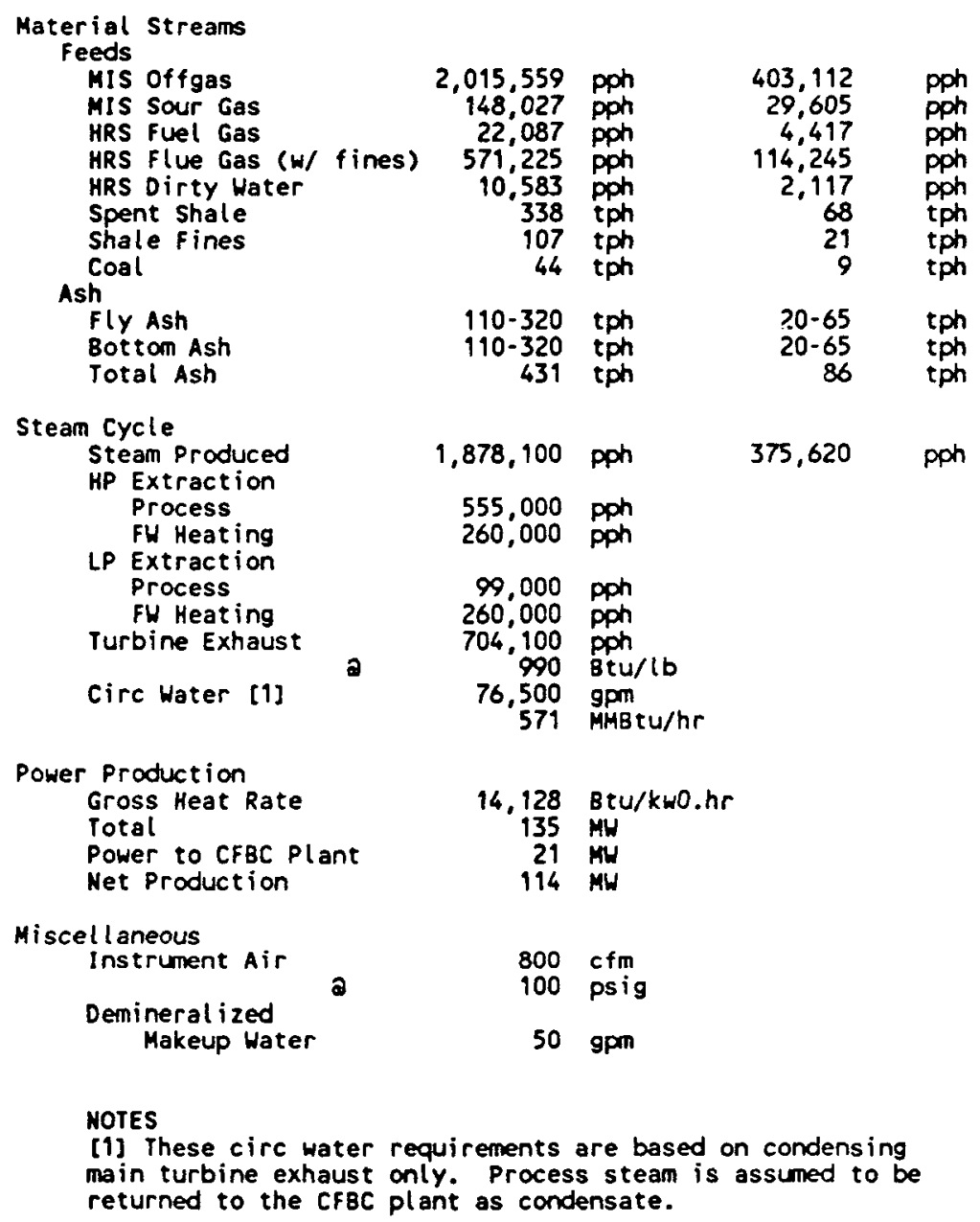


Table 7-7

CFBC

MATERIAL/ UTILITY BALANCE

CASE 2

ITEM

Material Streans

Feeds

MIS offgas

MIS Sour Gas

HRS Fuel Gas

HRS Flue Gas ( $w /$ fines)

MRS Dirty Water

Spent shale

Shale Fines

Coal

Limestone

Ash

Fly Ash

Bottom Ash

Total Ash

Steam Cycle

Steam Produced

HP Extraction

Process

FW Heating

LP Extraction

Process

FW Heating

Turbine Exhaust

Circ Water [1]

a

Power Production

Gross Heat Rate

Total

Power to CFBC PIant

Net Production

Miscell aneous

instrument Air

Demineralized

Makeup Water
QUANTITY

$183,182 \mathrm{pph}$

13,457 pph

1,699 pph

43,940 pph

$814 \mathrm{pph}$

26 tph

8.2 tph

21 tph

5.1 tph

11-34 tph

$11-34$ tph

$375,620 \mathrm{pph}$

46,000 pph

52,000 pph

11,000 pph

$52,000 \mathrm{pph}$

214,620 pph

$990 \mathrm{Btu} / \mathrm{lb}$

$23,500 \mathrm{gpm}$

$174 \mathrm{MMBtu} / \mathrm{hr}$

14,716 Btu/kw0.hr

$35.3 \mathrm{MH}$

4.2 MH

$31.1 \mathrm{MH}$

$200 \mathrm{cfm}$

100 psig

$10 \mathrm{gpm}$

NOTES

[1] These circ water requirements are based on condensing main turbine exhaust only. Process steam is assumed to be returned to the CFBC plant as condensate. 


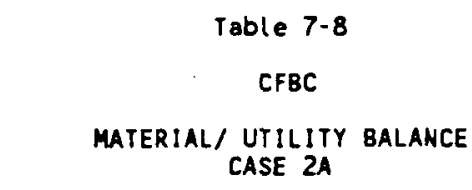

ITEM

QUANTITY

Material streams

Feeds

MIs offgas

MIS Sour Gas

HRS fuel Gas

HRS Flue Gas (w/ tines)

HRS Dirty Water

Spent Shale

Shale fines

Coal

Ash

Fly Ash

Botton Ash

Total Ash

$\begin{array}{rr}183,182 & \text { pph } \\ 13,457 & \text { pph } \\ 1,699 & \text { pph } \\ 43,940 & \text { pph } \\ 814 & \text { pph } \\ 26 & \text { tph } \\ 8.2 & \text { tph } \\ 4.2 & \text { tph } \\ 11-33 & \text { tph } \\ 11.33 & \text { tph } \\ 44 & \text { tph }\end{array}$

steam Cycle

Steam Produced

HP Extraction

Process

Fu Heating

LP Extraction

Process

FW Heating

Turbine Exhaust

a

Circ Water [1]

166, $260 \mathrm{pph}$

46,000 pph

23,000 pph

$11,000 \mathrm{pph}$

23,000 pph

63,260 pph

990 Btu/lb

$7,000 \mathrm{gpm}$

51 MHB tu/hr

Power Production Gross Heat Rate

Total

Power to CFBC Plant

Net Production

14,124 Btu/kwO.hr

$12.0 \mathrm{M}$

$2.0 \mathrm{MH}$

$10.0 \mathrm{MH}$

Miscell aneous

Instrument $A$ ir

อ

Demineral ized

Makeup Water

200 cfm

100 psig

4 gpm

NOTES

[1] These circ water requirements are based on condensing main turbine exhaust only. Process steam is assumed to be returned to the CFBC plant as condensate. 
Table 7-9

HRS ABOVE GROUNO RETORT FACILITIES

MATERIAL BALANCE - CASE 1

COMHERCIAL PLANT

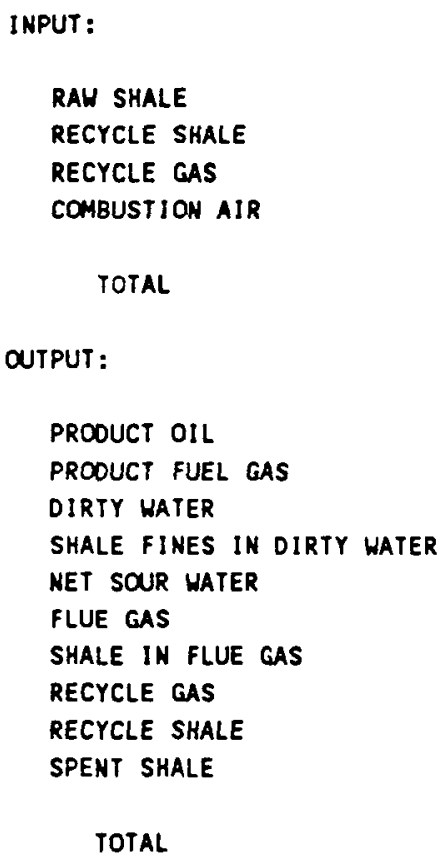

TPSO M LB/SHr

$\begin{array}{rr}12,850 & 1,071 \\ 38,551 & 3,213 \\ 822 & 69 \\ 6,478 & 540 \\ \ldots \ldots . . & \ldots \ldots \\ 58,701 & 4,892\end{array}$

$\begin{array}{rr}1,238 & 103 \\ 332 & 28 \\ 132 & 11 \\ 11 & 1 \\ 70 & 6 \\ 6,846 & 571 \\ 2,570 & 214 \\ 822 & 69 \\ 38,551 & 3,213 \\ 8,129 & 677 \\ \ldots \ldots .- & \ldots \ldots \\ 58,701 & 4,892\end{array}$


Table $7-10$

HRS ABOVE GROUND RETORT FACILITIES

MATERIAL BALANCE - CASES $2 \& 2 A$

DEMONSTRATION PLANT

INPUT :

RAW SHALE
RECYCLE SHALE
RECYCLE GAS
COMBUSTION AIR

TOTAL

OUTPUT:

PROOUCT OIL

PRCOUCT FUEL GAS

DIRTY HATER

SHALE FINES IN DIRTY WATER

NET SOUR WATER

FLUE GAS

SHALE IN FLUE GAS

RECYCLE GAS

RECYCLE SHALE

SPENT SHALE

TOTAL
TPSD LB/SHr

$\begin{array}{rr}1,000 & 83,333 \\ 3,000 & 250,000 \\ 64 & 5,331 \\ 504 & 42,010 \\ \ldots . . & \ldots . . . . \\ 4,568 & 380,674\end{array}$

$\begin{array}{rr}96 & 8,028 \\ 26 & 2,153 \\ 10 & 856 \\ 1 & 71 \\ 5 & 454 \\ 533 & 44,397 \\ 200 & 16,667 \\ 64 & 5,331 \\ 3,000 & 250,000 \\ 633 & 52,717 \\ \ldots . . & \ldots . .2 . \\ 4,568 & 380,674\end{array}$


Table $7 \cdot 11$

HRS ABOVE GROUND RETORT FACILITIES

material balance - case 3

PILOT PLANT

INPUT :

\begin{tabular}{lrr} 
RAW SHALE & 100 & 8,333 \\
RECYCLE SHALE & 300 & 25,000 \\
RECYCLE GAS & 6 & 533 \\
COMBUSTION AIR & 50 & 4,201 \\
\multicolumn{1}{c}{ TOTAL } & $\ldots-$ & $\ldots . .$. \\
& 457 & 38,067
\end{tabular}

OUTPUT:

PROOUCT OIL

PRODUCT FUEL GAS

DIRTY WATER

SHALE FINES IN DIRTY WATER

NET SOUR WATER

FLUE GAS

SHALE IN FLUE GAS

RECYCLE GAS

RECYCLE SHALE

SPENT SHALE

TPSD LB/SHr

TOTAL

$\begin{array}{rr}10 & 803 \\ 3 & 215 \\ 1 & 86 \\ <1 & 7 \\ 1 & 45 \\ 53 & 4,440 \\ 20 & 1,667 \\ 6 & 533 \\ 300 & 25,000 \\ 63 & 5,272 \\ \ldots & \ldots . . . \\ 457 & 38,067\end{array}$


Table 7-12

UTILITY REOUIREMENTS

CASE 1 - COMMERCIAL SIZE PLANT

\begin{tabular}{|c|c|c|c|c|c|c|c|c|c|c|}
\hline AREA & & MINING & $\begin{array}{l}6000 \\
\text { MIS PROCESS } \\
\text { FACILITIES }\end{array}$ & $\begin{array}{c}7000 \\
\text { STEAM/POWER } \\
\text { PLANT (CFBC) }\end{array}$ & $\begin{array}{c}4710 \\
\text { SHALE PREP. } \\
\text { AREA }\end{array}$ & $\begin{array}{l}4600 \\
\text { ABOVE GROUND } \\
\text { RETORT ING }\end{array}$ & $\begin{array}{c}5000 \\
\text { OIL } \\
\text { UPGRADING }\end{array}$ & $\begin{array}{l}\text { UTILITIES/ } \\
\text { OFFSITES }\end{array}$ & $\begin{array}{l}\text { TOTALS } \\
\text { SIREAM DAY } \\
\text { BASIS }\end{array}$ & $\begin{array}{l}\text { TOTALS } \\
\text { CALENDAR } \\
\text { DAY BASIS }\end{array}$ \\
\hline STREAM FACTOR & & 1.00 & 0.95 & 1.00 & 0.95 & 0.95 & 0.92 & 0.95 & & \\
\hline ELECTRICAL POWER & $K(H)$ & 13,000 & 34,268 & $(114,000)$ & 1,620 & 15,200 & 10,800 & 4,050 & $(35,062)$ & $(38,683)$ \\
\hline STEAM (M LB/HR) & $\begin{array}{l}1500 \text { PSIG } \\
600 \text { PSIG } \\
150 \text { PSIG } \\
50 \text { PSIG } \\
\text { BFW } \\
\text { CLEAN CONDENSATE } \\
\text { BD }\end{array}$ & & $\begin{array}{l}450 \\
211 \\
\\
(661)\end{array}$ & $\begin{array}{r}(555) \\
(99) \\
25 \\
654 \\
(25)\end{array}$ & & & $\begin{array}{l}33 \\
(4) \\
(72) \\
195 \\
186\end{array}$ & $\begin{array}{c}103 \\
(103)\end{array}$ & $\begin{array}{l}31 \\
5 \\
(72) \\
220 \\
179 \\
(25)\end{array}$ & $\begin{array}{l}0 \\
0 \\
(0) \\
(66) \\
204 \\
197 \\
(25)\end{array}$ \\
\hline WATER (M LB/HR) & $\begin{array}{l}\text { RAW WATER } \\
\text { WASTE WATER }\end{array}$ & (925) & $(460)$ & & 15 & 22 & & 2,395 & $\begin{array}{r}1,047 \\
0\end{array}$ & $\begin{array}{r}948 \\
0\end{array}$ \\
\hline COOLING (MM BTU/HR) & $\begin{array}{l}\text { AlR } \\
\text { WATER }\end{array}$ & & $\begin{array}{l}783 \\
702\end{array}$ & & & 93 & 36 & & $\begin{array}{l}783 \\
831\end{array}$ & $\begin{array}{l}744 \\
789\end{array}$ \\
\hline COOLING WATER & (GPM) & & 84,500 & 76,500 & 10 & 9.268 & 2,900 & 50 & 173,228 & 168,305 \\
\hline FUEL (MM BTU/HR) & $\begin{array}{l}\text { NG/FG } \\
\text { SHALE } \\
\text { MIS GAS } \\
\text { COAL }\end{array}$ & 15 & & $\begin{array}{c}292 \star \star \\
\cdots \\
1,746 \\
896\end{array}$ & & $61 \star$ & 671 & 10 & $\begin{array}{r}757 \\
0 \\
0 \\
896\end{array}$ & $\begin{array}{r}700 \\
0 \\
0 \\
896\end{array}$ \\
\hline AIR (SCFM) & PLANT/INSTR. & 400 & 850 & 800 & 100 & 300 & 800 & & 3,250 & 3,124 \\
\hline
\end{tabular}

( ) INDICATES NET PROOUCTION OF UTILITY

* NET FUEL NG/FG REQUIRED: RETORT PROOUCT $=27,633$ LB/HR LESS FUEL GAS TO CFBC $=22,087$ LB/HR

IS 5,546 LB/HR. ( 114 MMBTU/HR HEAT RELEASED/0.85)-(365 RETORT PRODUCT - 292 FG TO CFBC) 61 MM BTU/HR

THIS CALCULATION TAKES CREDIT FOR THE BTU CONTENT OF THE FUEL GAS NOT FED TO THE CFBC.

** FUEL GAS PRODUCED BY ABOVE GROUND RETORT 
Table 7-13

UTILITY REQUIREMENTS

CASE 2/2A - DEMONSTRATION SIZE PLANT

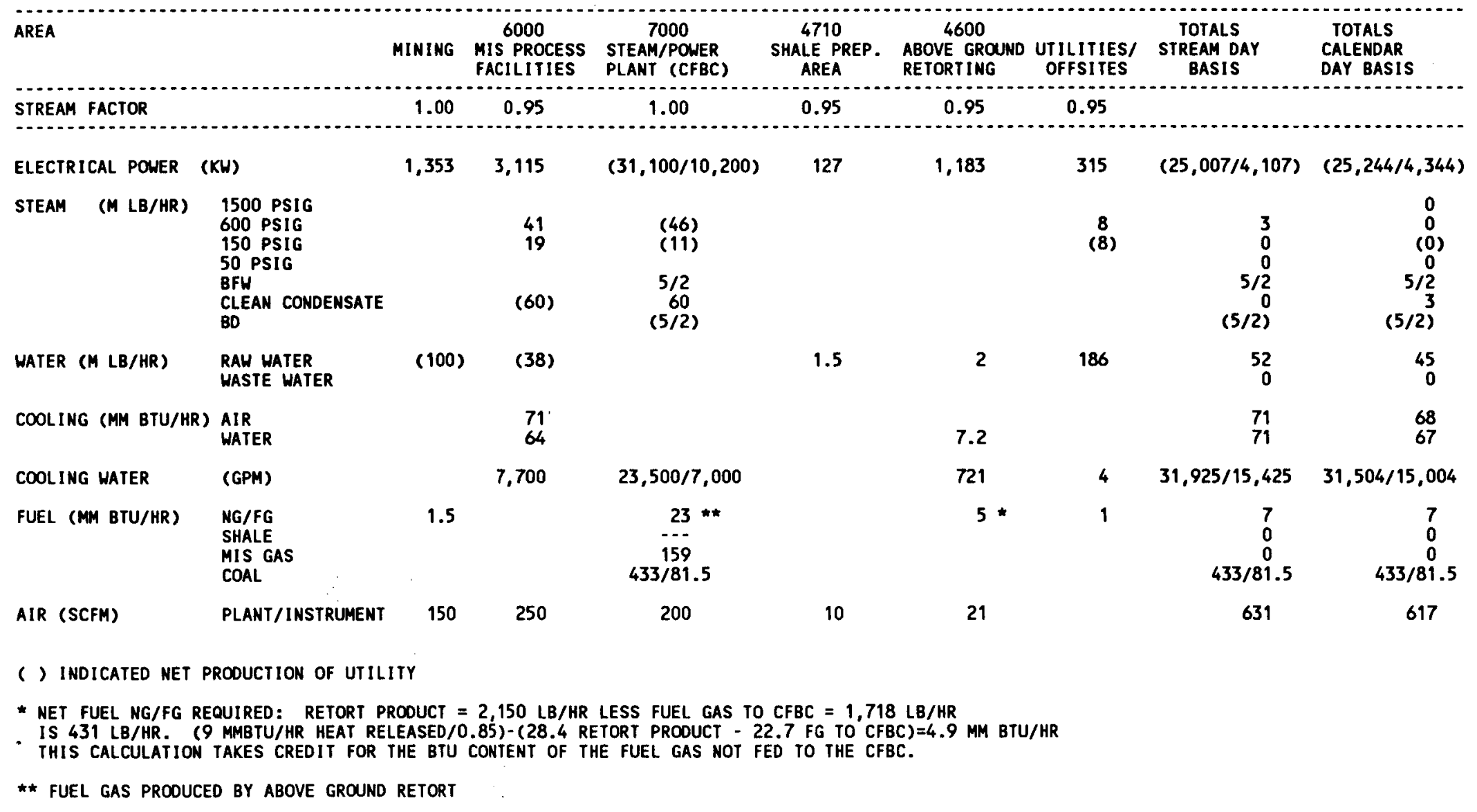


Table 7-14

UTILITY REOUIREMENTS

CASE 3 - PILOT SIZE PLANT

\begin{tabular}{|c|c|c|c|c|c|}
\hline AREA & & $\begin{array}{l}4600 \\
\text { ABOVE GROUND } \\
\text { RETORTING }\end{array}$ & $\begin{array}{c}\text { UTILITIES/ } \\
\text { OFFSITES }\end{array}$ & $\begin{array}{l}\text { TOTALS } \\
\text { STREAM DAY } \\
\text { BASIS }\end{array}$ & $\begin{array}{c}\text { TOTALS } \\
\text { CALENDAR } \\
\text { DAY BASIS }\end{array}$ \\
\hline STREAM FACTOR & & 0.95 & 0.95 & & \\
\hline ELECTRICAL PONER & $\mathrm{KW})$ & 148 & 32 & 180 & 171 \\
\hline STEAM (M LB/HR) & $\begin{array}{l}1500 \text { PSIG } \\
600 \text { PSIG } \\
150 \text { PSIG } \\
50 \text { PSIG } \\
\text { BFW } \\
\text { CLEAN CONDENSATE } \\
\text { BD }\end{array}$ & & $\begin{array}{l}0 \\
0\end{array}$ & $\begin{array}{l}0 \\
0\end{array}$ & $\begin{array}{l}0 \\
0\end{array}$ \\
\hline WATER ( $M$ LB/HR) & $\begin{array}{l}\text { RAW WATER } \\
\text { WASTE WATER }\end{array}$ & 1 & 19 & 20 & 19 \\
\hline COOLING (MM BTU/HR) & $\begin{array}{l}\text { AIR } \\
\text { WATER }\end{array}$ & 1 & & & \\
\hline COOLING WATER & (GPM) & 72 & 0 & 72 & 68 \\
\hline FUEL (MM BTU/HR) & $\begin{array}{l}\text { NG } / F C \\
\text { SHALE } \\
\text { MIS GAS } \\
\text { COAL }\end{array}$ & $1 \cdot$ & Neg. & 1 & 1 \\
\hline AIR (SCFM) & PLANT/INSTRUMENT & 2 & & 2 & 2 \\
\hline
\end{tabular}

( ) INDICATED NET PRODUCTION OF UTILITY

MEAT ABSORBED IN PROCESS HEATERS

Neg. = Negligible, i.e., less than $0.1 \mathrm{MMBtu} / \mathrm{Hr}$. 
Table 7-15

CATALYST AND CHEMICAL CONSUMPTION

CASE 1 - COMMERCIAL SIZE PLANT

MIS SURFACE FACILITIES

AREA 6010 UNDERGROUND RETORT SYSTEM

DEMULSIFIER, TRETOLITE RP729 GAL

CONSUMPTION

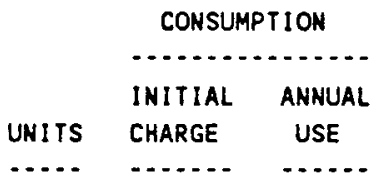

.... ....... ....

ANHYDROUS AMMONIA

LBS $220,000 \quad 27,500$

ABOVE GROUND RETORT

AREA 4615

FRACTIONATION

TRETOLITE

96\% SULFURIC ACIO

L8S $\quad 39,585 \quad 158,340$

DEMULSIFIER

LBS

$59,378 \quad 158,200$

GAL

588

OIL UPGRADING

AREA 5010

HYOROGEN PLANT

REFORMER CATALYST

FT^3 $\quad 825 \quad 413$

HT SHIFT CATALYST

ZINC OXIDE

COBALT MOLY CATALYST

$F^{\wedge} 3$

$\mathrm{FT}^{\wedge} 3$

$\mathrm{FT}^{\wedge} 3$

PSA ADSORBENT

HYDRAZINE

AMINE

CAUSTIC

FT^3

GAL

GAL

GAL

$\begin{array}{rr}924 & 309 \\ 825 & 550 \\ 289 & 97 \\ 26,175 & \text { NIL } \\ 41 & \text { NIL } \\ 41 & \text { NIL } \\ 41 & \text { NIL }\end{array}$

AREA 5020

HYDROTREATING UNIT

ALUMINA BALLS

DEARSENITING CATALYST

PRETREAT CATALYST

HYDROTREATING CATALYST

HT CATALYST, NON-NOBLE

DI-METHYL SULFIDE

NI TROGEN

LBS

LBS

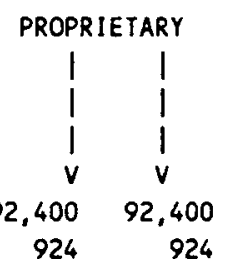


Table 7-16

CATALYST AND CHEMICAL CONSUMPTION

CASES 2 and 2A. DEMONSTRATION SIZE PLANT

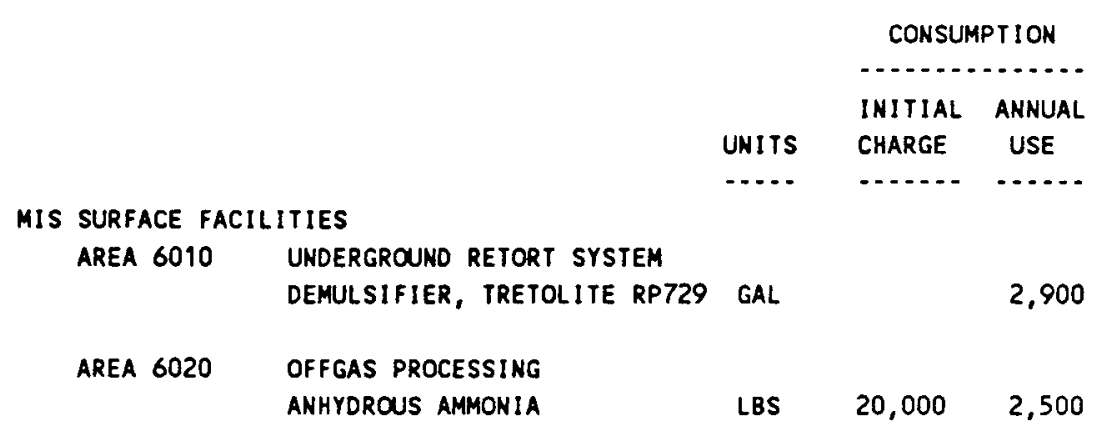


Figure 7-1

LOCATION OF C-b TRACT

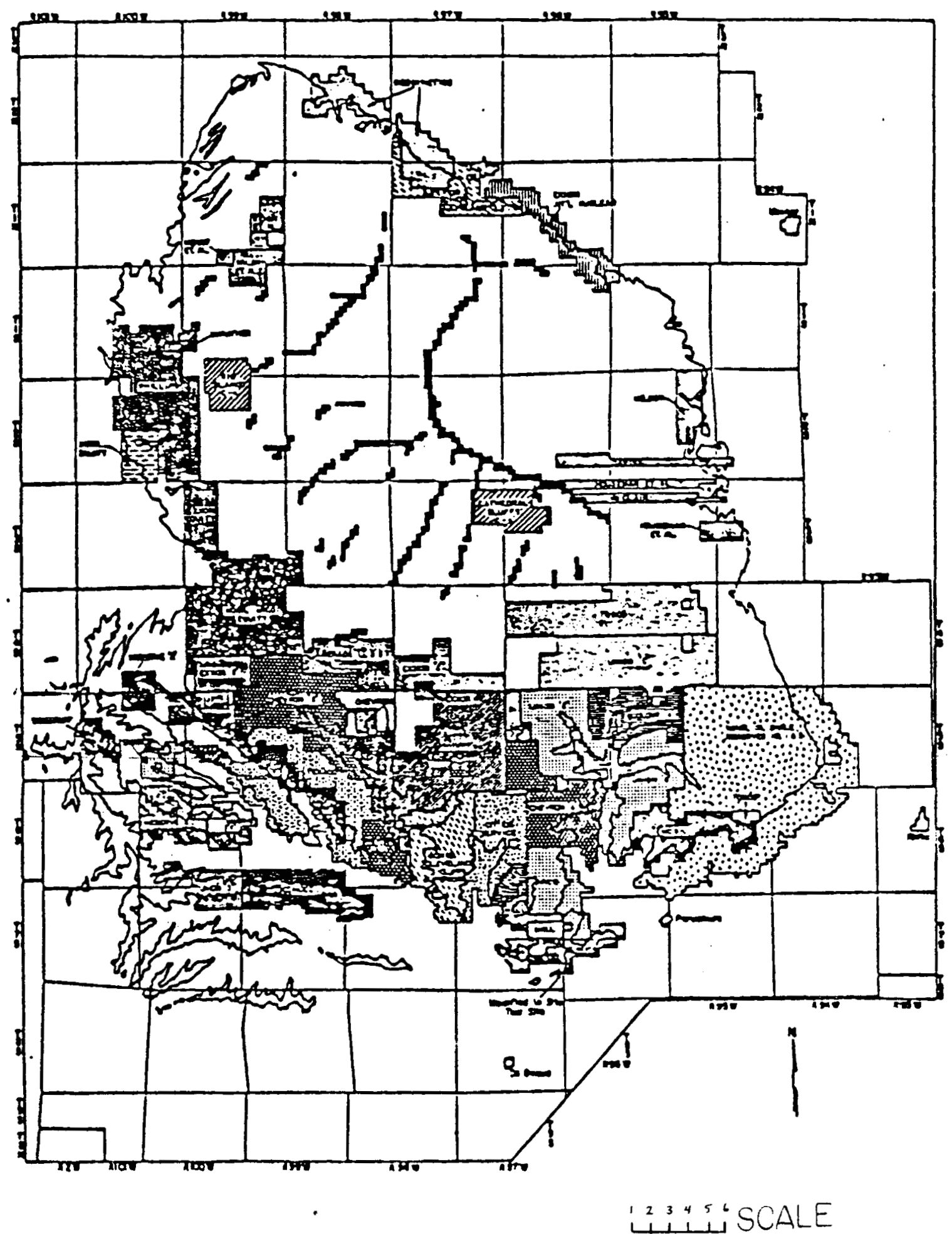




\section{LOCATION C-b TRACT}

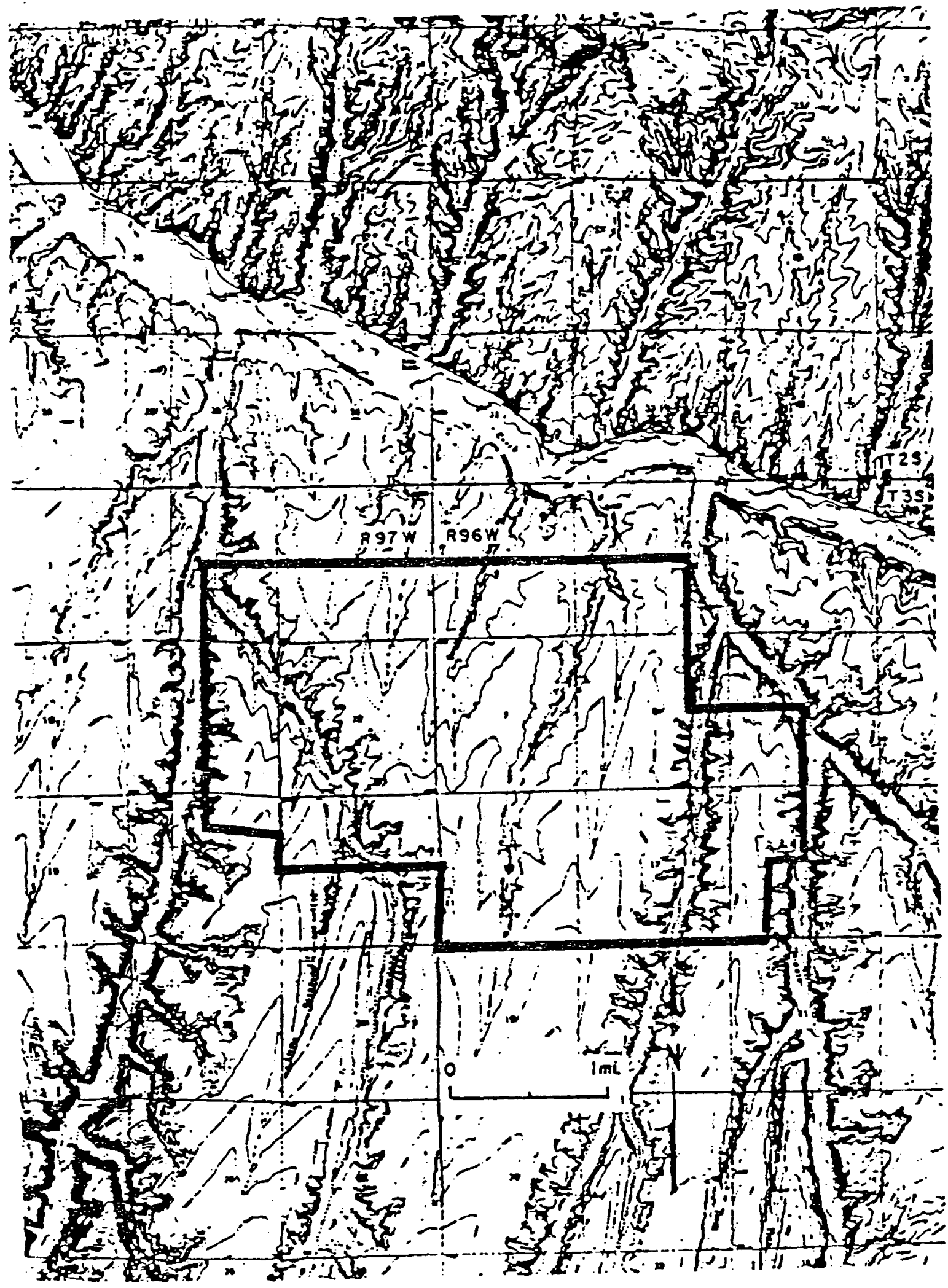


Figure $7-3$

MIS MINE ISOMETRIC

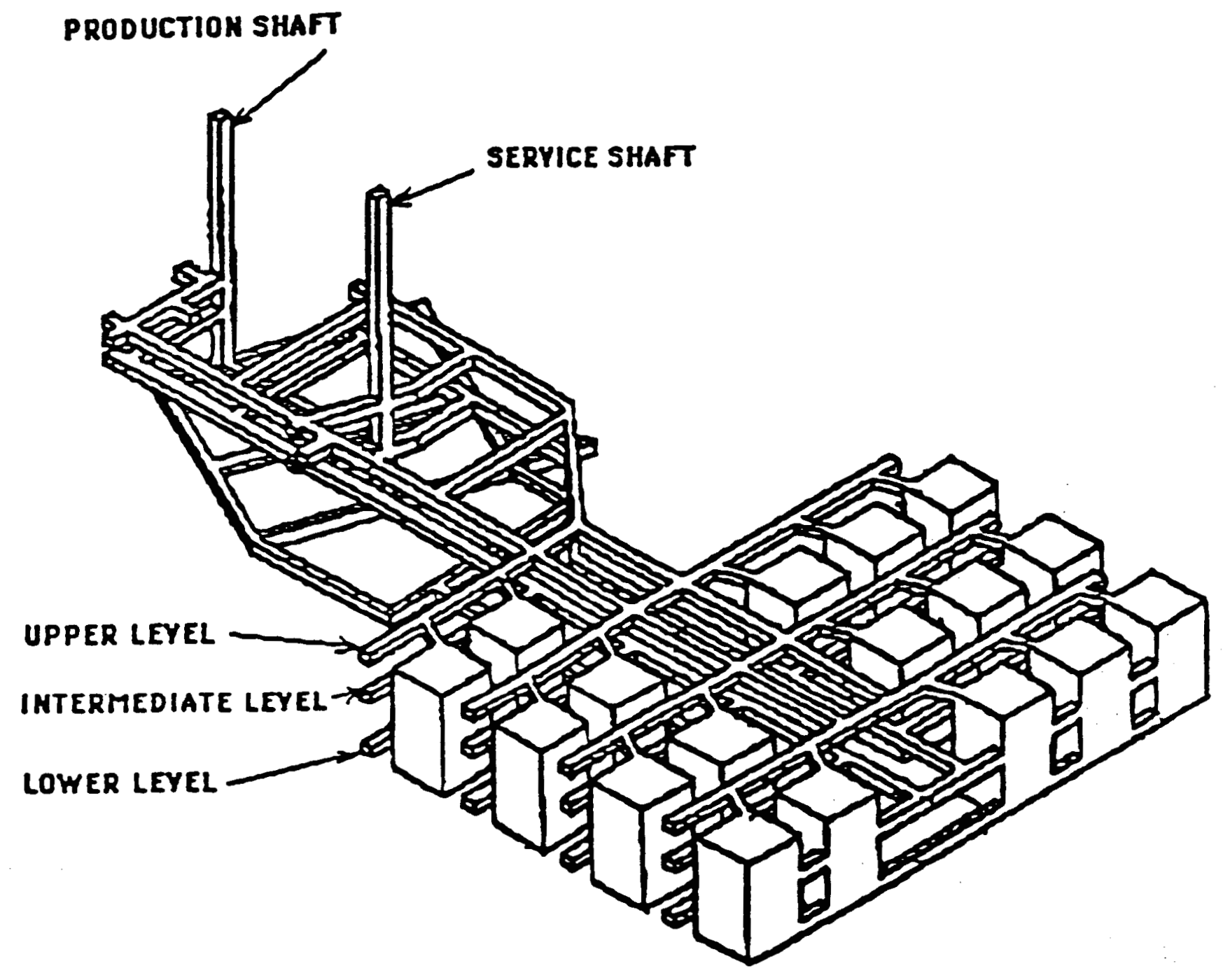


Figure $7-4$

\section{OVERALL PLOT PLAN}

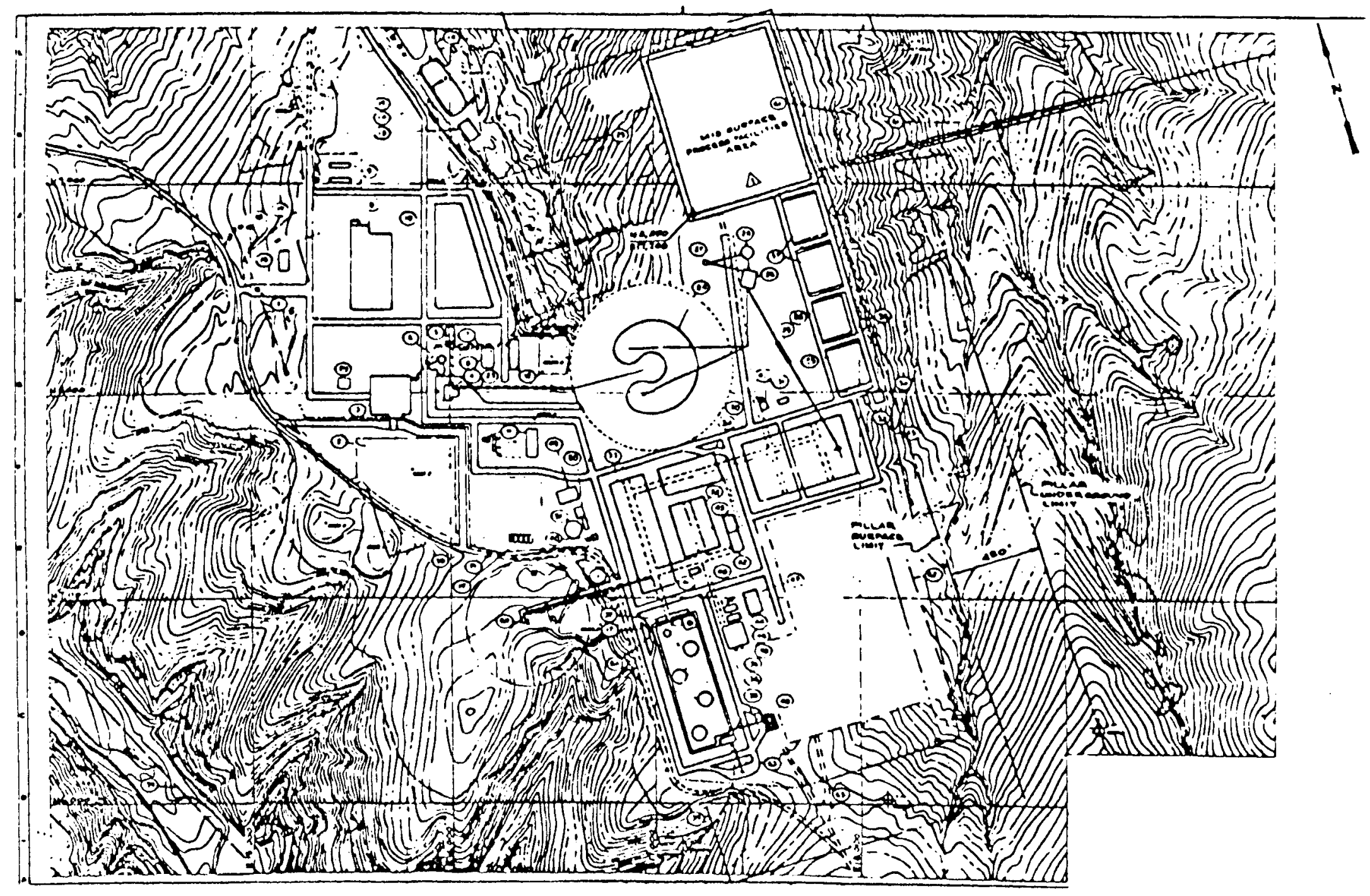


Figure 7-5

BLOCK FLOW DIAGRAM

COMMERICAL SIZE PLANT

CASE 1

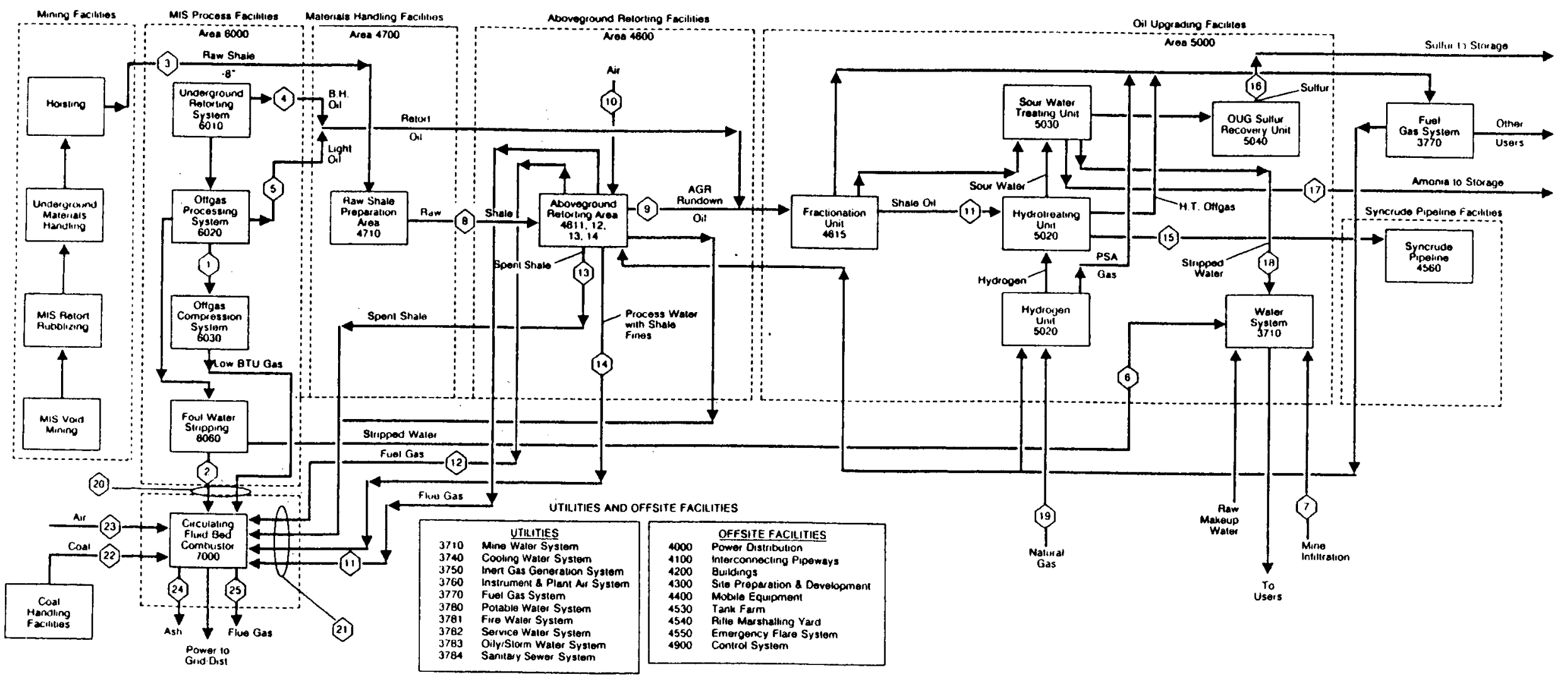


Figure 7.6

BLOCK FLOW DIAGRAM

STRATION SIZ
CASES 2, 2A

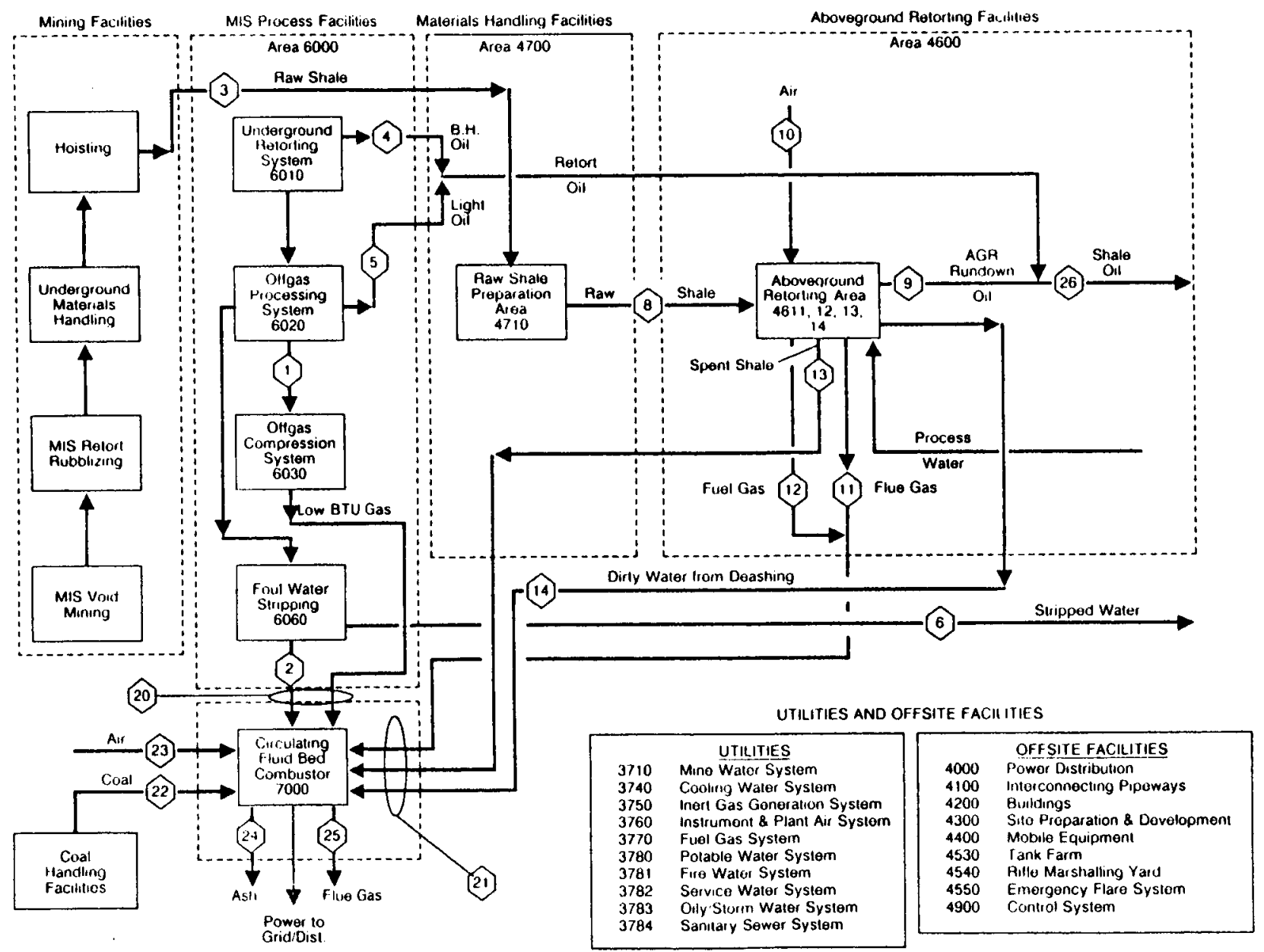


Figure 7-7

\section{BLOCK FLOW DIAGRAM \\ PILOT SCALE PLANT \\ CASE 3}

Raw Shale

from Stockpile

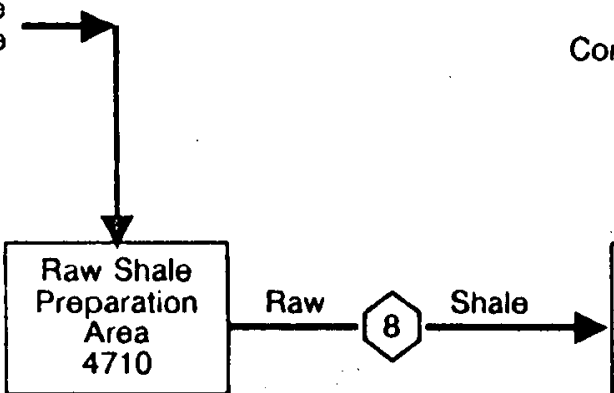

Combustion

Air

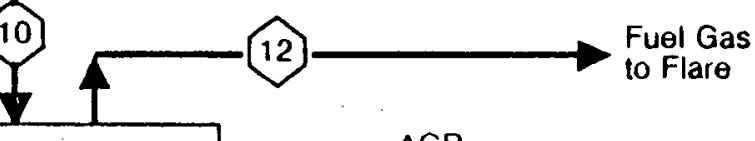

Aboveground -9 Rundown To Storage

14.

Oil

Process Water

Spent Shale

Flue Gas

$1<$

Vent Gas

Spent Shale

System

4616

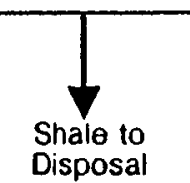

UTILITIES AND OFFSITE FACILITIES

\begin{tabular}{|ll|}
\hline & \multicolumn{1}{c|}{ UTILITIES } \\
3710 & Mine Water System \\
3740 & Cooling Water System \\
3750 & Inert Gas Generation System \\
3760 & Instrument \& Plant Air System \\
3770 & Fuel Gas System \\
3780 & Potable Water System \\
3781 & Fire Water System \\
3782 & Service Water System \\
3783 & Oily/Storm Water System \\
3784 & Sanitary Sewer System \\
\hline
\end{tabular}

4000

4100

4200
4300

4400

4540

4540
4550

4550
4900
OFFSITE FACILITIES

Power Distribution

Interconnecting Pipeways

Buildings

Site Preparation \& Development

Mobile Equipment

Tank Farm

Rifie Marshalling Yard

Emergency Flare System

Control System 
Figure $7-8$

SHALE PROCESSING PLANT

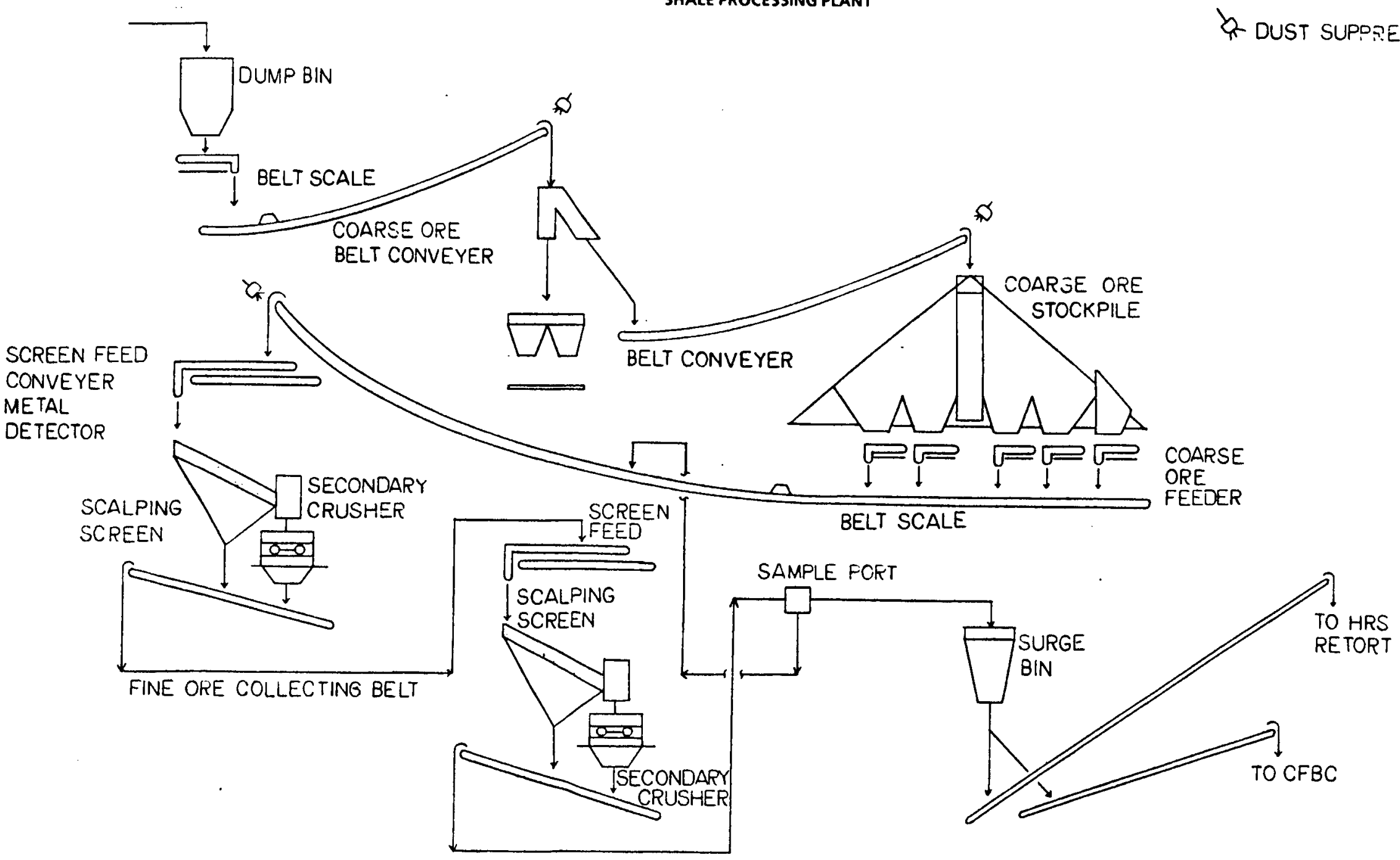




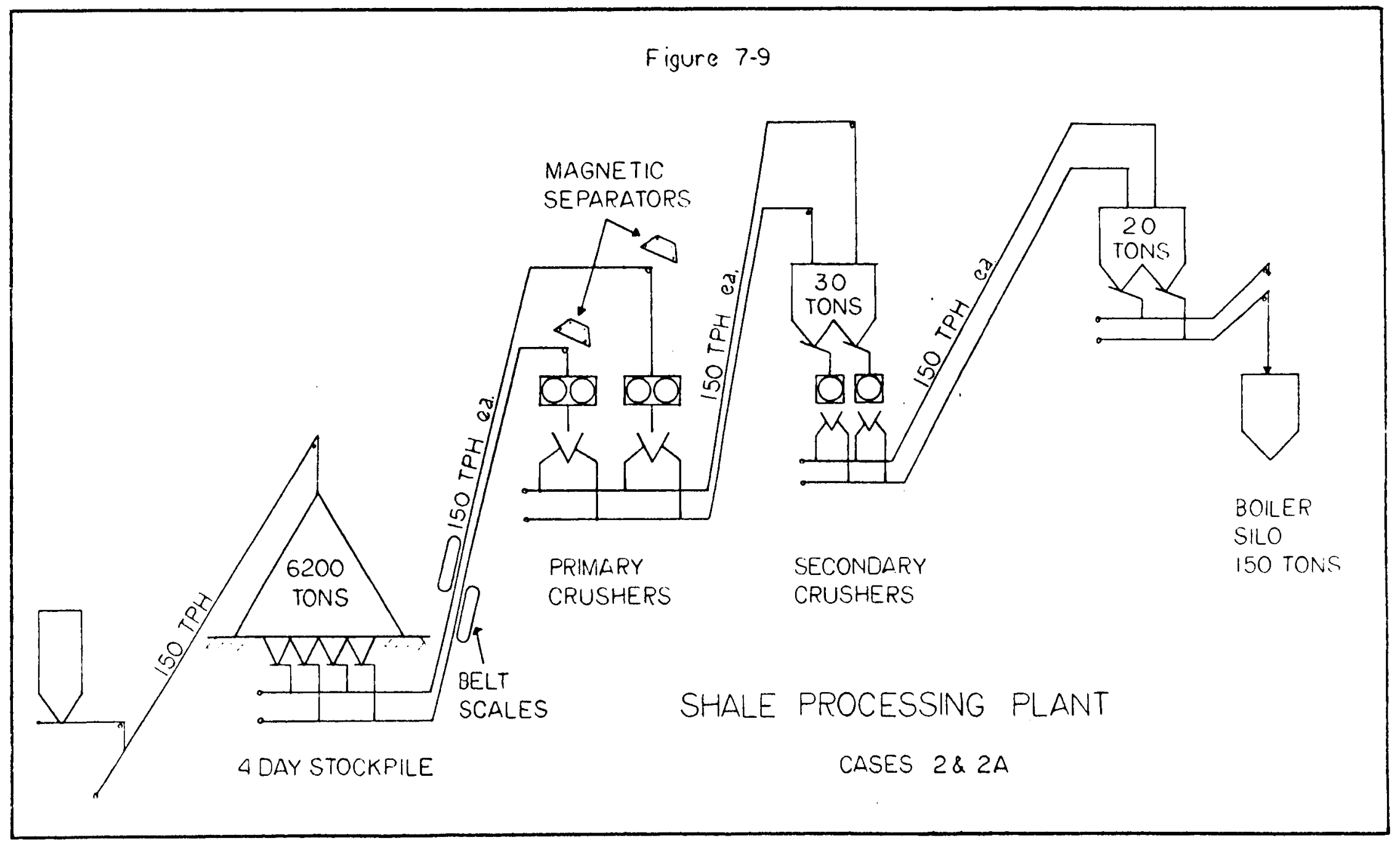




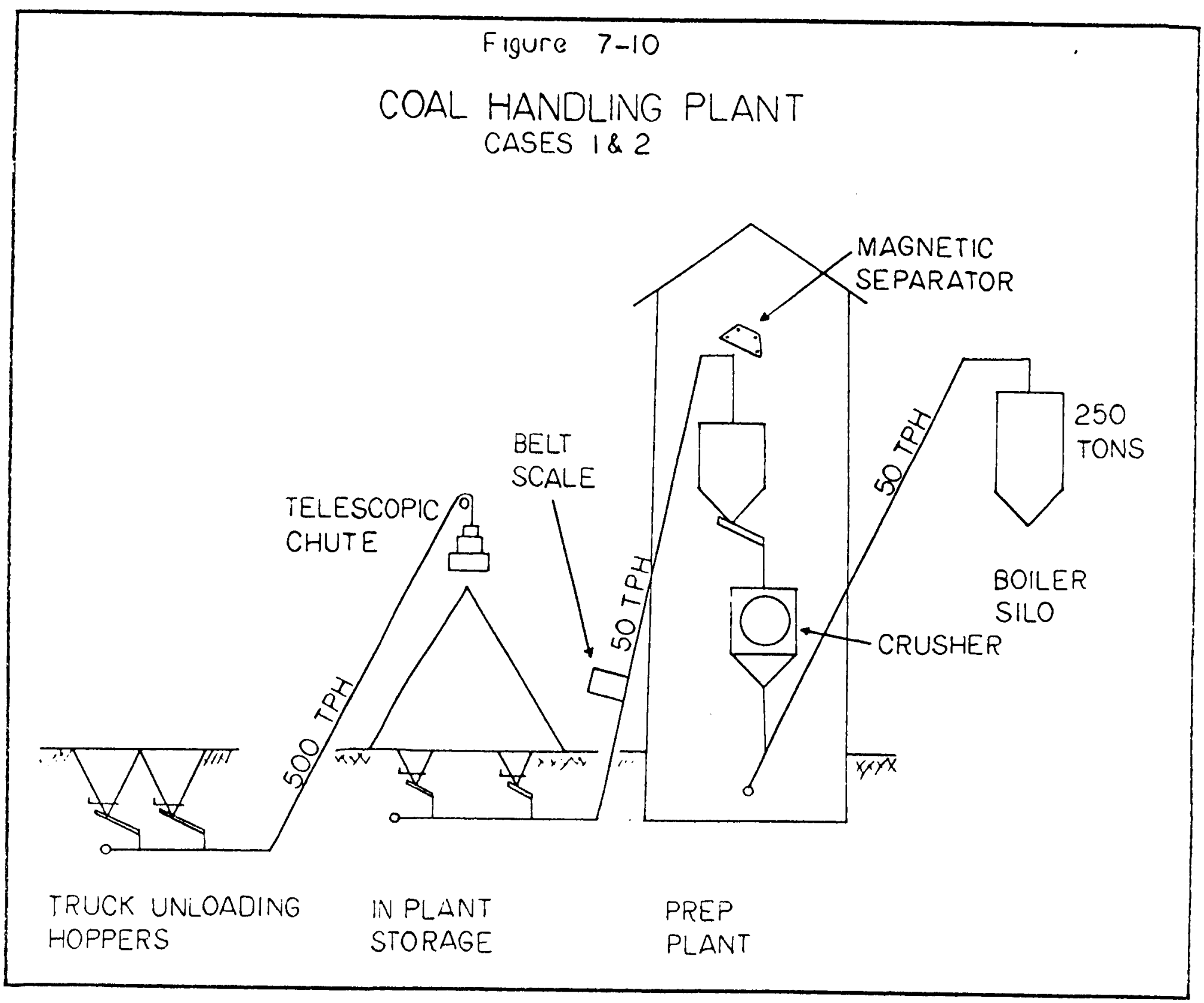


Figure 7-11

\section{CFBC/POWER PLANT}

\section{COMBUSTION-SIDE SCHEMATIC}

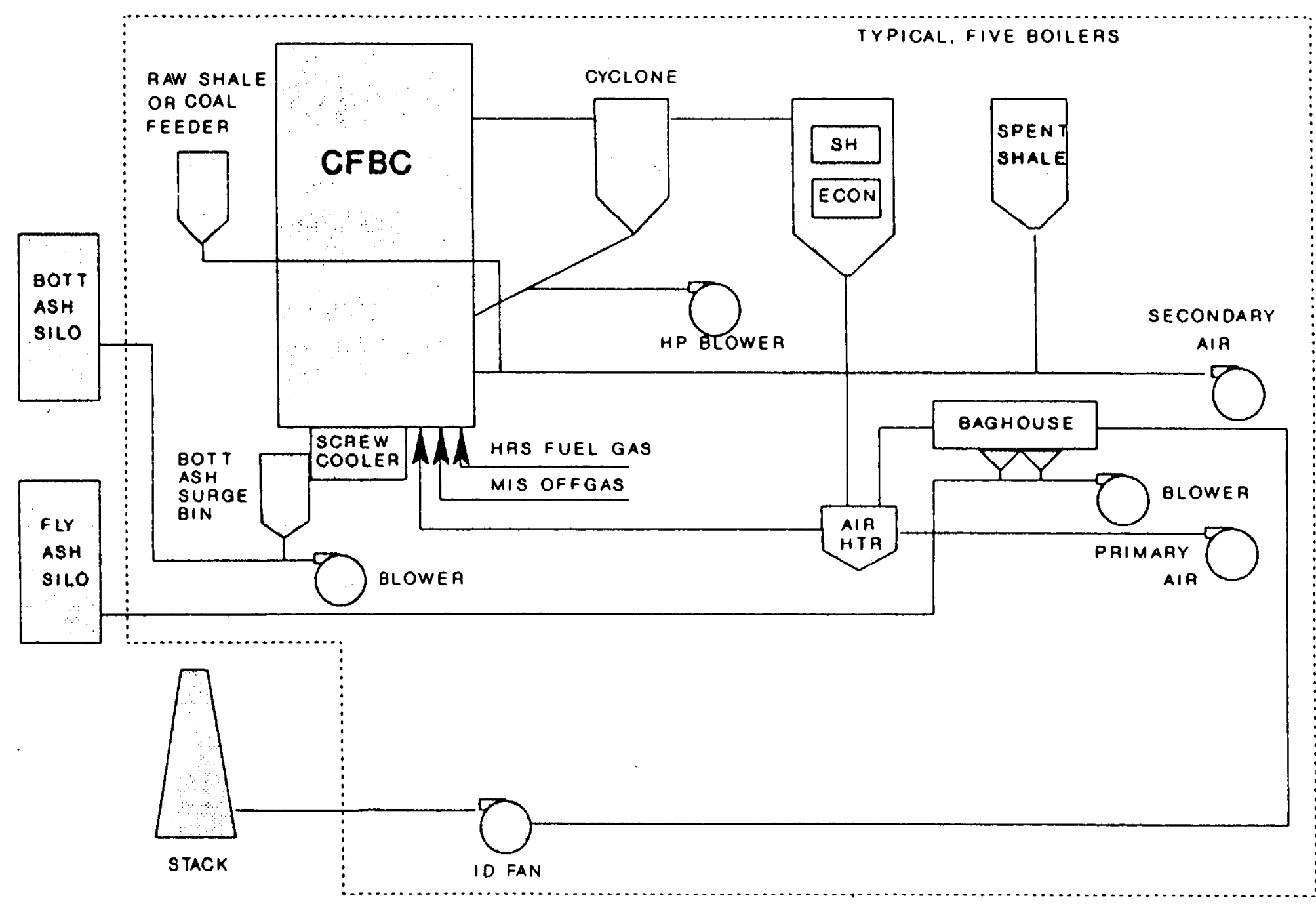


Figure 7-12

\section{CFBC/POWER PLANT STEAM-SIDE SCHEMATIC}

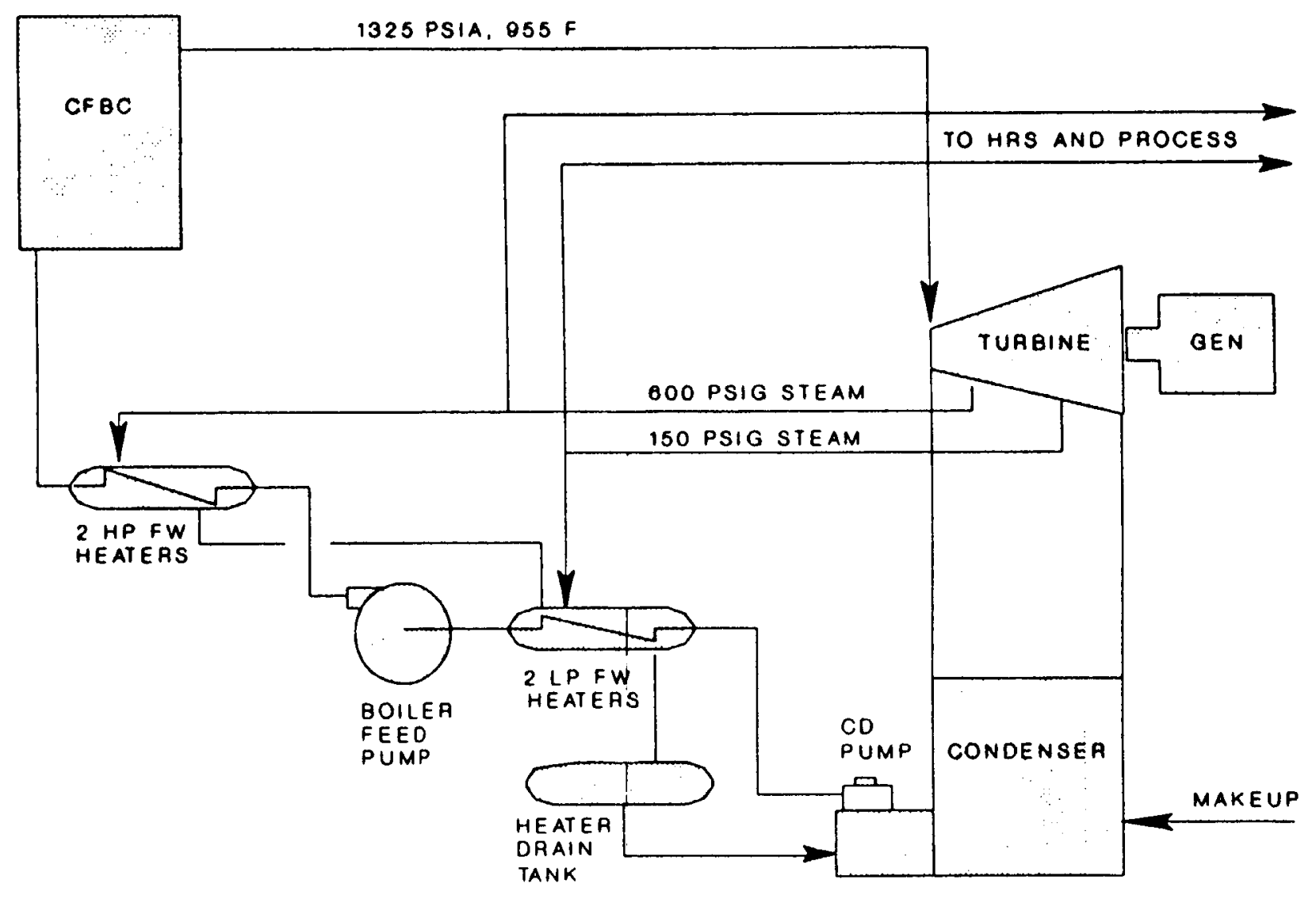


Figure 7-13

HRS RETORT ASSEMBLY

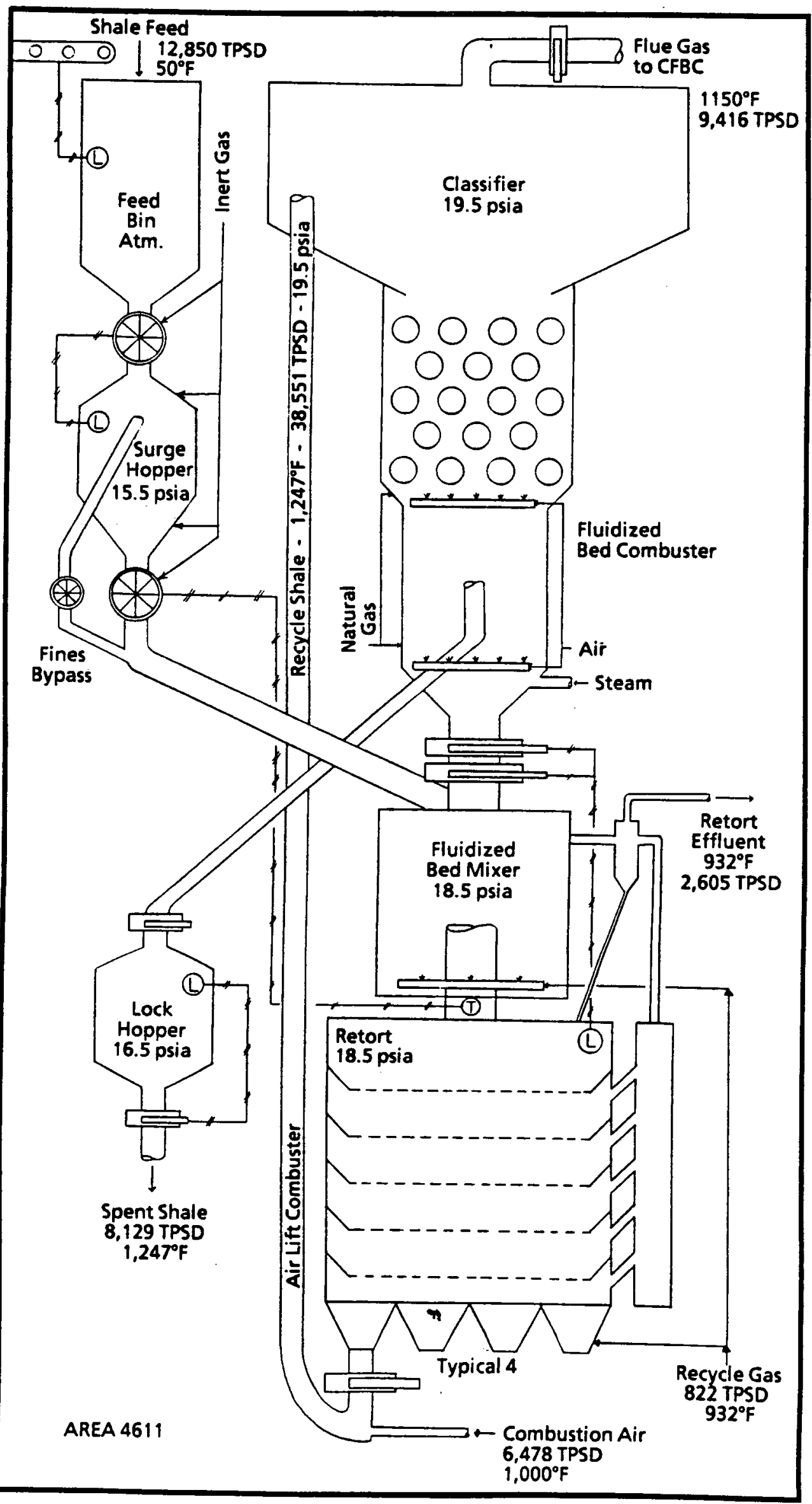


Figure 7-14

HRS RETORT GAS PROCESSING FLOW DIAGRAM

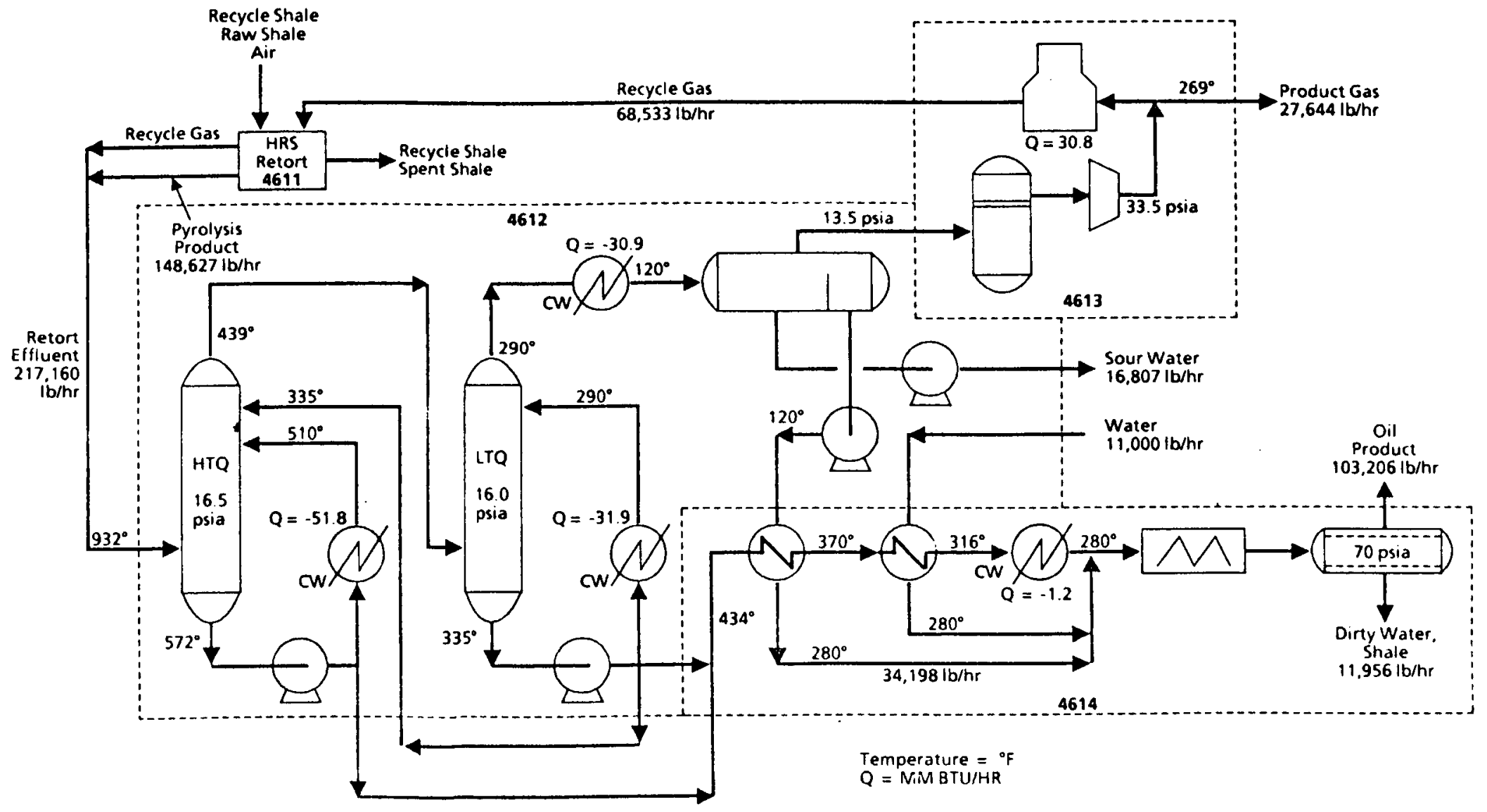


Figure 7-15

MRS SPENT SHALE

PNEUMATIC TRANSPORT AND COOLING SYSTEM - CASE 3

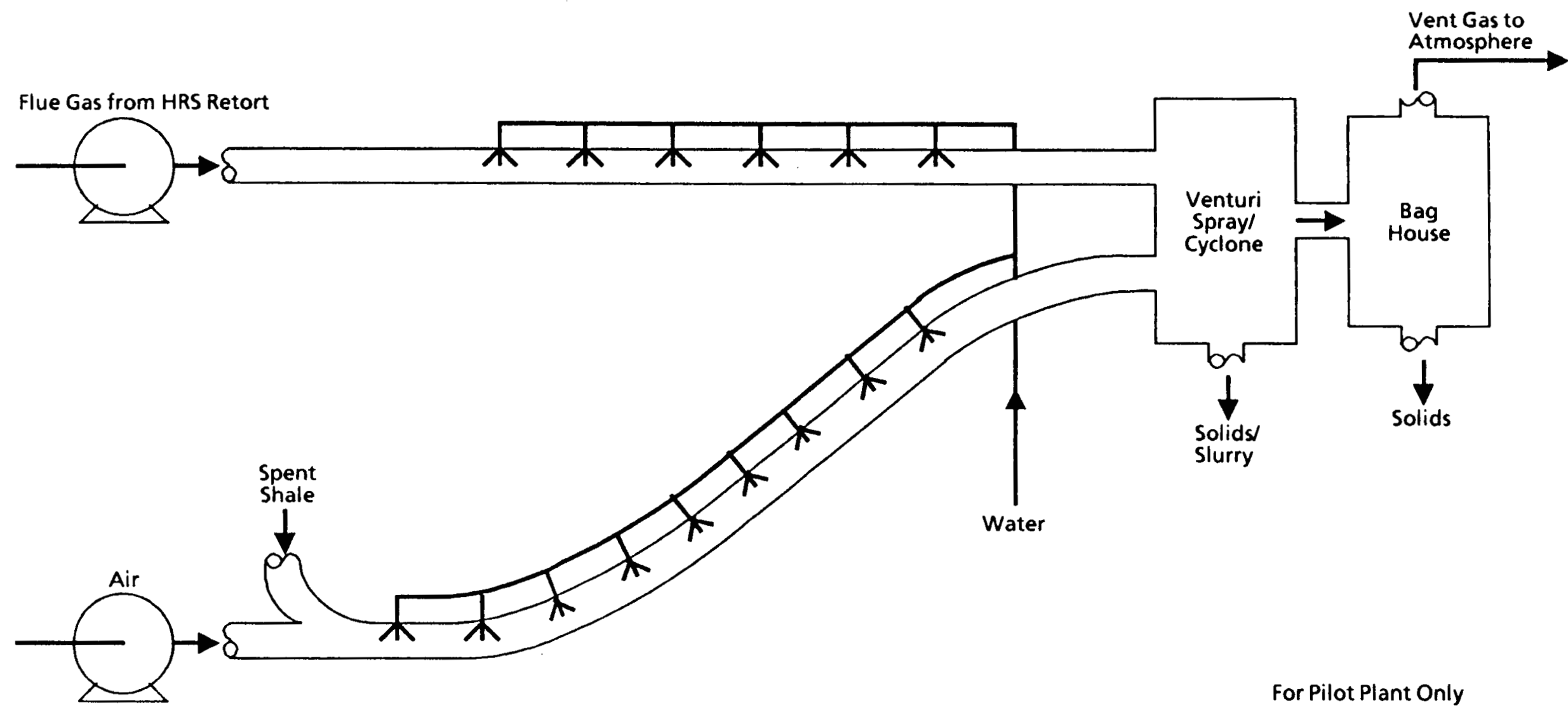


This section discusses the technical feasibility of the various process areas.

MODIFIED-IN-SITU RETORT

Modified-In-Situ (MIS) technology has been developed and demonstrated by Occidental Oil Shale, Inc. at its Logan Wash site. Field testing at this site began in 1972 and the first experimental retort was ignited in 1973. A total of 11 experimental retorts have been in operation, including two units which were of commercial size. MIS retorting has been demonstrated at other locations. The Demonstration size facility will perfect the MIS system in this specific geological area and integrate the MIS below ground system with the above ground facilities. Improvements for conserving energy in rubblization, obtaining higher oil recovery and reducing mining costs will be forthcoming with more site-specific experience.

MODIFIED-IN-SITU OFF-GAS PROCESSING

Processing the MIS off-gas utilizes conventional refinery type hydrocarbon processing technologies of water scrubbing, sponge oil absorption, gas compression, and foul water stripping. These technologies have been used extensively in petroleum refining throughout the world.

\section{ABOVE GROUND RETORTING}

The Above Ground Retort employs an innovative concept developed by Lawrence Livermore National Laboratory (LLNL) which uses a recirculating hot-solid heat carrier in a continuous loop system.

The principle scale-up concern is the maintenance of uniform temperature and composition gradients through the retort in order to verify the laboratory results. For example, the laboratory size retort (in which this concept has been studied by LLNL) is four inches in diameter and the Pilot plant retort is 42 inches in diameter. This represents a scale up on flow area basis of more than 100 to 1 .

Similarly, the proper functioning of the air lift combustor, the classifier, the delayed fall combustor, the fluidized bed combustor 
and the fluidized bed mixer needs to be verified for this magnitude of scale-up.

\section{CIRCULATING FLUIDIZED BED Combustor (CFBC)}

CFBC technology has been demonstrated on a commercial scale, but not with the particular combination of fuels envisioned in this study. These fuels consist of HRS spent shale, HRS fuel gas, HRS flue gas, MIS sour gas, MIS off-gas and coal. Field tests, studies and laboratory evaluations have been conducted on oil shale combustion. A reasonable level of confidence has been reached that the shale will burn satisfactorily in a CFBC. It has also been shown that alkaline materials in the shale will act as an efficient $\mathrm{SO}_{2}$ adsorbent which will result in the flue gas meeting environmental requirements.

The environment under which the CFBC must perform with the various fuel mixes is unique. Areas deemed necessary for exploration are:

- Boundaries of fuel mixes which will sustain stable combustion. The fuel mix off-gas, raw shale and spent shale is probably the most critical.

- The effect of these low-heating value and high-bulk fuels on the costs and economic viability of the CFBC.

- Equipment life expectancy when using these high-bulk, lowheating value fuels.

- The economic effect of the additional raw shale mining which may be required to supply supplemental fuel for the CFBC.

- Sulfur removal efficiency. The variability of sulfur in the various fuels will need to be established in order that proper estimation of sulfur emissions can be made.

Prior to the final process design, areas of optimization will be identified for each significant design variable. Proper allowances will be made during the detailed equipment design.

\section{OIL UPGRADING FACILITY}

The oil upgrading plant consists of standard petroleum refining units including a hydrotreater, a hydrogen plant, a sulfur recovery plant and an ammonia recovery unit, all of which pose little risk. The hydrotreater poses a certain element of risk since it requires somewhat severe operating conditions. The ammonia recovery 
unit will operate with a feed different from normal. This feed change is not considered a high risk.

Both the MIS and HRS processes generally produce a lighter oil with a lower $\mathrm{N}_{2}$ content than typical shale oils. This may reduce the upgrading costs.

Union's Parachute Creek facility has processed 1.5 million barrels of oil shale into a premium syncrude product. Oil shale has been successfully refined in oil shale operations in Sweden, Scotland, Australia, West Germany, the USSR and other countries. These have generally been on a relatively small scale and under special economic conditions. 
APPENDIX

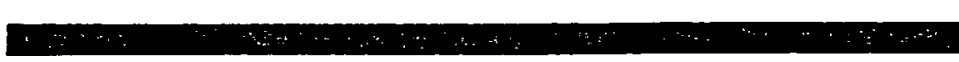




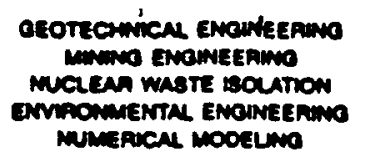

\title{
J. F. T. AGAPITO \& ASSOCLATES, INC. CONSULTINO OEOTECHNICA MND MININO ENGINEERS \\ 715 HORIZON DRIVE, SUITE 300 \\ GRAND JUNCTION, COLORADO 81506
}

June 9,1989

\author{
Dr. Ray Zahradnik \\ Occidental Oil Shale, Inc. \\ 1250 South Lincoln Avenue, Suite I-5 \\ P. O. Box 880408 \\ Steamboat Plaza \\ Steamboat Springs, CO 80488
}

Re: Occidental C-b; 14 Retort Demonstration Project, Mining Costs

Dear Ray:

This letter summarizes our preliminary estimate of costs to mine the access drifts and upper void, intermediate void, lower void, and production levels from the existing C-b service and production shafts. Our costs include personnel, equipment and supplies to:

- excavate shops and developments on each level;

- excavate upper void, intermediate void, lower void, and production levels for 14 retorts;

- excavate one ore pass connection for the upper and intermediate levels to the lower level;

- jaw crusher and associated loading facilities at the lower level;

- a shaft bottom cleanup system;

- ventilation system including surface fans and underground auxiliary distribution system; and

- pumping costs to lift mine water to the surface.

The estimates dn not include the cost to rubbilize the material in the retorts, nor the cost to equip and operate the retorts and hoist the oil shale to the surface. Also, not included are the costs to excavate and line a shaft for the retort offgases. We have assumed that the product offgases will require a dedicated lined shaft with finished diameter of six feet. The cost of this shaft with liner could be as much as $\$ 6.9 \times 10^{6}$ if excavated by blind hole drilling (as was the USBM Horse Draw Shaft) or substantially lower if raise bore techniques can be used. It may be possible to install the production offgas pipe in the production shaft, but more engineering would be required before a cost estimate of that alternative could be presented. 
Dr. Ray Zahradnik

June 9, 1989

Page 2

The mining cost estimate is based on using the existing equipment available at the site and appropriate new equipment where necessary. Table 1 lists the equipment and estimated capital costs.

Personnel costs are based on Unocal's current labor rates with a 1.4 multiplier to cover fringe benefits, FICA, worker compensation, vacation, sick leave, etc. We have assumed operations on a four day, two shifts per day, ten hours per shift basis. Personnel lists and rates are shown in Table 2. We have not included costs for inflation.

The equipment and crew are capable of mining oil shale at a slightly higher rate than required to develop $2-1 / 2$ retorts per year. The project was planned to optimize production rate and assumes minimal interference from other retort activities. The peak rock production is 61,800 tons per month or 3,600 tons per working day. Figure 1 shows the production rate per quarter. At the rate shown, all 14 retorts could be developed in 57 months. Mining of the first retort void level would begin in Month 7. The first two retorts would be ready for rubbilization in Month 16. The total production is $2,414,200$ tons.

Based on the above schedule, the steady state mining production costs averaged between the 3 rd and 14th quarters were $\$ 9.97$ per ton of mined rock. The production costs include labor, supplies, maintenance, equipment operations, installation of crusher, lifting mine water to surface and ventilation (including shaft heating in winter), but not capital costs or depreciation. Table 3 summarizes these operating costs and also lists total costs that include capital amortized over the 57 months. Figure 2 shows the production cost per quarter, Figure 3 the production cost per ton per quarter, and Figure 4 the cumulative production cost per ton.

There are two options for presentation of this cost estimate you might consider. The first is to amortize the capital costs over the mine production. The capital costs (excluding the offgas shaft) is estimated to be $\$ 4,200,000$ or approximately $\$ 1.74$ per ton. This would bring the overall cost per ton to $\$ 13.23$ per ton (total operating cost plus capital/total tons produced).

The second alternative is to extend the mining schedule by nine months using the same equipment and crew. This would be consistent with the 2.5 retorts per year schedule used in the previous studies, and may occur because of unforeseen delays caused by coordination problems with the other underground operations of rubbilization, retort preparation, and retort operation. We have considered the impact on costs of extending the mining schedule by three quarters. Additional costs would include labor, pumping and ventilation (including heating in the winter), and would add $\$ 1.12$ to the overall cost, or $\$ 14.35$ per ton of mined oil shale.

We intend to address steady state costs of the commercial size operation when Roger Moore returns from Britian. We will be following this up with more complete data next week. If you have any questions or need more backup, please call.

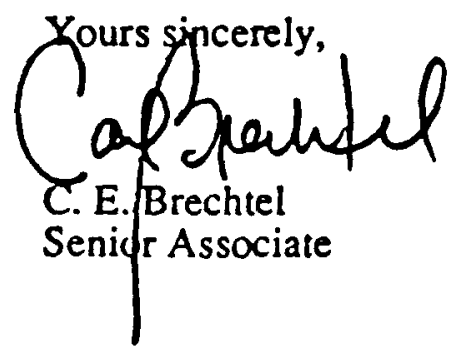


TABLL 1 CAPITAL EXPENDITURES

\begin{tabular}{|c|c|c|}
\hline DESCRIPTION & $\begin{array}{ll}\text { IISSABLE } \\
\text { Y } & N \\
\text { E } & 0 \\
\text { S } & \end{array}$ & (DOLLARS) \\
\hline MODIFY LXISTING JUMBO & $\bar{Y}$ & 100000 \\
\hline "COPPER RANGE" JUMBO & $\mathbf{Y}$ & 550000 \\
\hline BENCH DRILL & $\mathbf{N}$ & 325000 \\
\hline JACKLEGS & N/A & 10000 \\
\hline SHOTCRETE PLANT & $N / A$ & 60000 \\
\hline EIMCO 918LHD & $\mathbf{Y}$ & N/A \\
\hline EIMCO 918LHD & $\mathbf{Y}$ & N/A \\
\hline EIMCO 913 LHD & $\mathbf{Y}$ & 145000 \\
\hline EIMCO 913 LHD & $\mathrm{Y}$ & 145000 \\
\hline EIMCO 985-T15 DUMP TRUCK & $\mathrm{N}$ & 125000 \\
\hline EIMCO 985-T15 DUMP TRUCK & $N$ & 125000 \\
\hline EIMCO 985-T15 DUMP TRUCK & $\mathbf{N}$ & 125000 \\
\hline SCALER & $\mathbf{Y}$ & 290000 \\
\hline POWDER TRUCK & $\mathbf{Y}$ & 120000 \\
\hline UTILITY LIFT TRUCK & $Y$ & 100000 \\
\hline ELEVATING PLATFORM TRK & $\mathbf{Y}$ & 120000 \\
\hline MECHANICS TRUCK & $\mathbf{N}$ & 70000 \\
\hline TRACTOR WATER & $\mathbf{N}$ & 14000 \\
\hline TRACTOR VENT CREW & $\mathbf{N}$ & 14000 \\
\hline TRACTOR MECHANICS & $\mathbf{N}$ & 14000 \\
\hline TRACTOR UTILITY & $\mathrm{N}$ & 14000 \\
\hline TANKER FUEL & $N / A$ & 10000 \\
\hline TANKER FUEL & N/A & 10000 \\
\hline TANKER FUEL & N/A & 10000 \\
\hline TANKER FUEL & $N / A$ & 10000 \\
\hline TANKER WATER & $N / A$ & 10000 \\
\hline TANKER WATER & $N / A$ & 10000 \\
\hline MATERIAL TRAILER & $N / A$ & 8000 \\
\hline MATERIAL TRAILER & $N / A$ & 8000 \\
\hline MATERIAL TRAILER & N/A & 8000 \\
\hline POWDER TRAILER & $N / A$ & 15000 \\
\hline POWDER TRAILER & $N / A$ & 15000 \\
\hline MINE FAN & $\mathbf{N}$ & 144000 \\
\hline AUX FANS & $\mathbf{Y}$ & 35000 \\
\hline AUX FANS & $\mathbf{Y}$ & 35000 \\
\hline AUX FANS & $\mathbf{Y}$ & 35000 \\
\hline AUX FANS & $Y$ & 35000 \\
\hline AUX FANS & $\mathbf{Y}$ & 35000 \\
\hline AUX FANS & $Y$ & 35000 \\
\hline AUX FANS & $Y$ & 35000 \\
\hline AUX FANS & $\mathbf{Y}$ & 35000 \\
\hline AUX FANS & $Y$ & 35000 \\
\hline COMPRESSORS & & 150000 \\
\hline SHOP TOOLS & & 200000 \\
\hline SHAFT CLEAN-OUT & & 80000 \\
\hline HYDRAULIC ROCK BREAKER & & 45000 \\
\hline CRUSHER & & 465000 \\
\hline CONVEYOR & & 150000 \\
\hline \multicolumn{3}{|l|}{ TOTAL } \\
\hline
\end{tabular}


TABLE 2 ESTIMATED CB MINING OPERATIONS LABOR COSTS

\begin{tabular}{|c|c|c|}
\hline & $\therefore O B$ TITLE & WAGE \\
\hline & $\begin{array}{l}\text { MINE MANAGER } \\
\text { MINE ENGINEER } \\
\text { ENGINEER TECH } \\
\text { SECRETARY } \\
\text { MAINT SUPT } \\
\text { MINE SUPT } \\
\text { SHIFT FOREMAN } \\
\text { SHIFT FOREMAN } \\
\text { MAINT FORMAN } \\
\text { MAINT FORMAN }\end{array}$ & $\begin{array}{l}60000 \\
40000 \\
25000 \\
12000 \\
35000 \\
40000 \\
35000 \\
35000 \text { 2ND SHIFT } \\
35000 \\
35000 \text { 2ND SHIFT }\end{array}$ \\
\hline 10 & TOTAL SALARY & \\
\hline $\begin{array}{l}4 \\
4 \\
1 \\
1 \\
4 \\
4 \\
6 \\
4 \\
2 \\
2 \\
6 \\
2 \\
2 \\
2 \\
2 \\
2\end{array}$ & $\begin{array}{l}\text { IUMBO OP } \\
\text { HELPER } \\
\text { BENCH DRILLER } \\
\text { HELPER } \\
\text { POWDERMAN } \\
\text { HELPER } \\
\text { LHD OPER } \\
\text { TRUCK DRIVER } \\
\text { SCALER OPER } \\
\text { BULL GANG LEAD } \\
\text { BULL GANG } \\
\text { TOP LANDER } \\
\text { TOP LANDER OP } \\
\text { CRUSHER OP } \\
\text { HELPER } \\
\text { SKIP TENDER }\end{array}$ & $\begin{array}{r}16.60 \\
13.00 \\
13.00 \\
9.50 \\
13.00 \\
9.50 \\
16.60 \\
13.00 \\
16.60 \\
13.00 \\
9.50 \\
9.50 \\
13.00 \\
16.60 \\
9.50 \\
9.50\end{array}$ \\
\hline $\begin{array}{l}2 \\
4 \\
4 \\
2 \\
2 \\
2\end{array}$ & $\begin{array}{l}\text { MECHANIC I } \\
\text { MECHANIC II } \\
\text { MECHANIC III } \\
\text { OILER } \\
\text { ELECTRICIAN } \\
\text { HELPER }\end{array}$ & $\begin{array}{r}16.60 \\
13.00 \\
9.50 \\
9.50 \\
16.60 \\
13.00\end{array}$ \\
\hline
\end{tabular}

64 TOTAL HOURLY 
TABLE I MINE PRODUCTION NWD COST SUMARY FOR IA RETORT DENONSTRATION PROJECT

\begin{tabular}{|c|c|c|c|c|c|c|c|c|c|}
\hline QTR & IINE PERIOO & TONS & $\begin{array}{l}\text { CYM } \\
\text { MiHED }\end{array}$ & $\begin{array}{l}\text { MIN } \\
\text { OPE } \\
\text { COSIS }\end{array}$ & $\begin{array}{l}\text { CHA } \\
\text { Môn } \\
\text { OP } \\
\text { cosis }\end{array}$ & 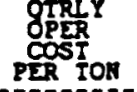 & $\begin{array}{l}\text { TOTAL } \\
\text { MIN } \\
\text { COOSTS }\end{array}$ & $\begin{array}{l}\text { CUM } \\
\text { MTAN } \\
\text { COSTS }\end{array}$ & $\begin{array}{l}\text { OTRYY } \\
\text { IOTIN } \\
\text { COST } \\
\text { PER TOK }\end{array}$ \\
\hline $\begin{array}{r}71 \\
\frac{2}{3} \\
4 \\
5 \\
6 \\
7 \\
8 \\
9 \\
10 \\
11 \\
12 \\
13 \\
13 \\
15 \\
115 \\
11 \\
18 \\
19\end{array}$ & 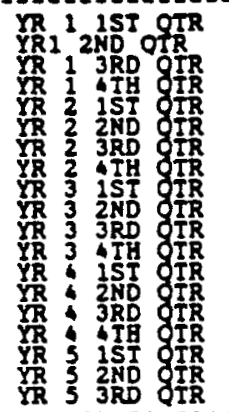 & $\begin{array}{r}62532 \\
184031 \\
15546 \\
149350 \\
177602 \\
167314 \\
160167 \\
176394 \\
165140 \\
139607 \\
185281 \\
163592 \\
160225 \\
89662 \\
100086 \\
94893 \\
96242 \\
17655\end{array}$ & $\begin{array}{r}62532 \\
266563 \\
612012 \\
560362 \\
733964 \\
905238 \\
1045645 \\
1221839 \\
1386979 \\
1526586 \\
1711867 \\
1875458 \\
2015684 \\
2105366 \\
2205432 \\
2300325 \\
2396567 \\
2414222\end{array}$ & 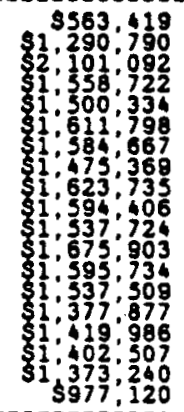 & 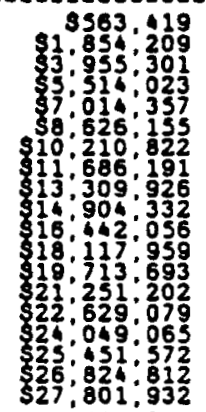 & 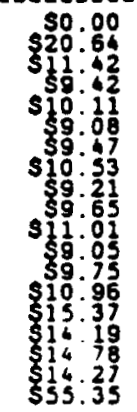 & 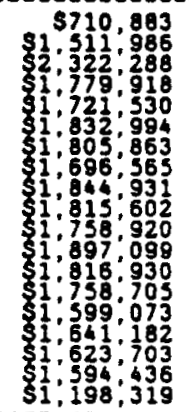 & 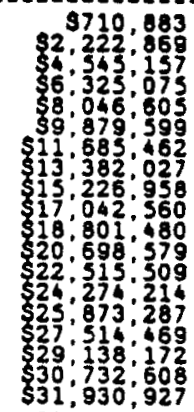 & 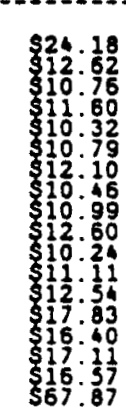 \\
\hline
\end{tabular}




\section{FIGURE 1 - QUARTERLY AND CUMULATIVE MINE PRODUCTION 14 RETORT DEMONSTRATION PROJECT}

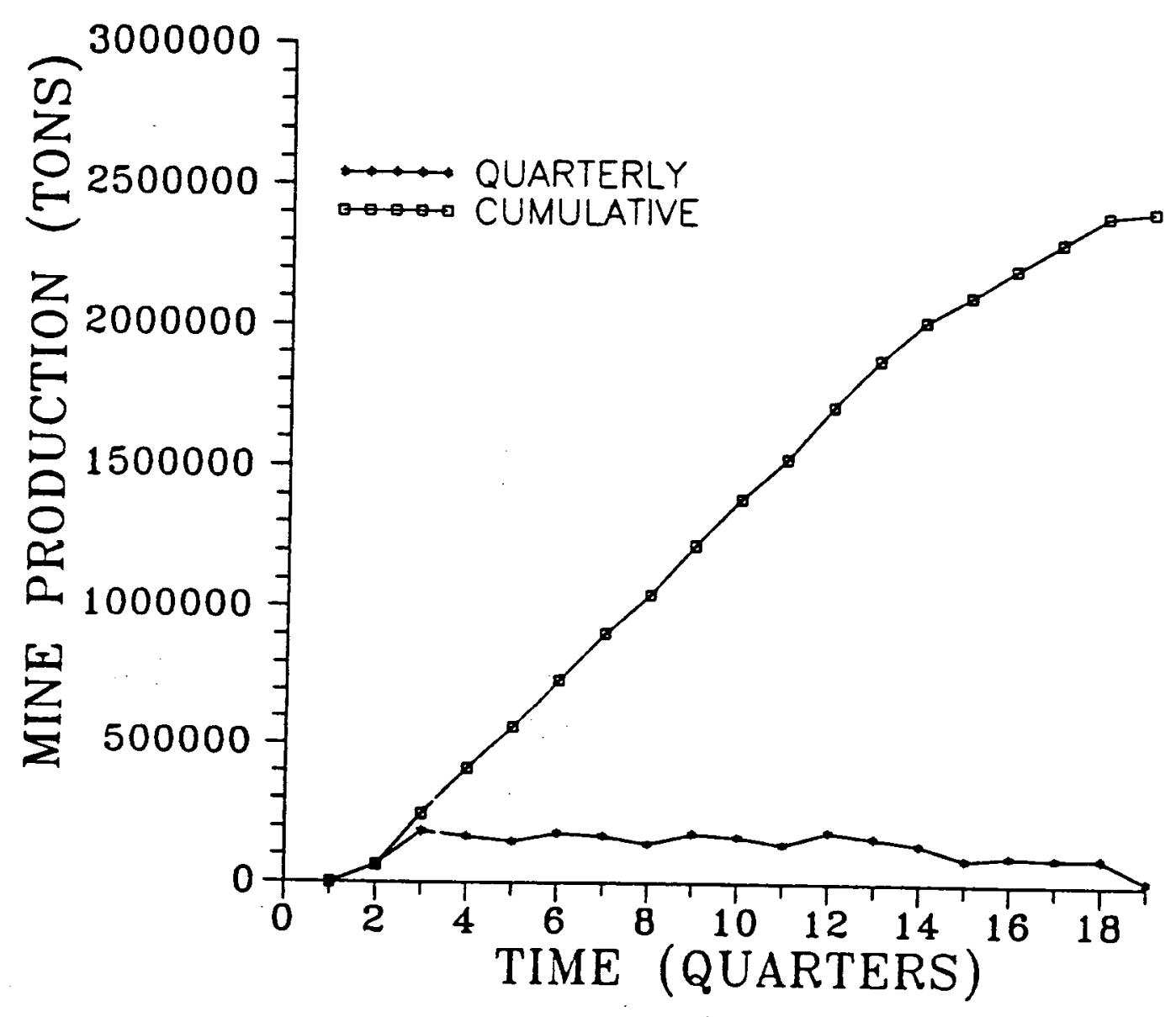


FIGURE 2 - OPERATING AND TOTAL PRODUCTION COST PER TON 14 RETORT DEMONSTRATION PROJECT

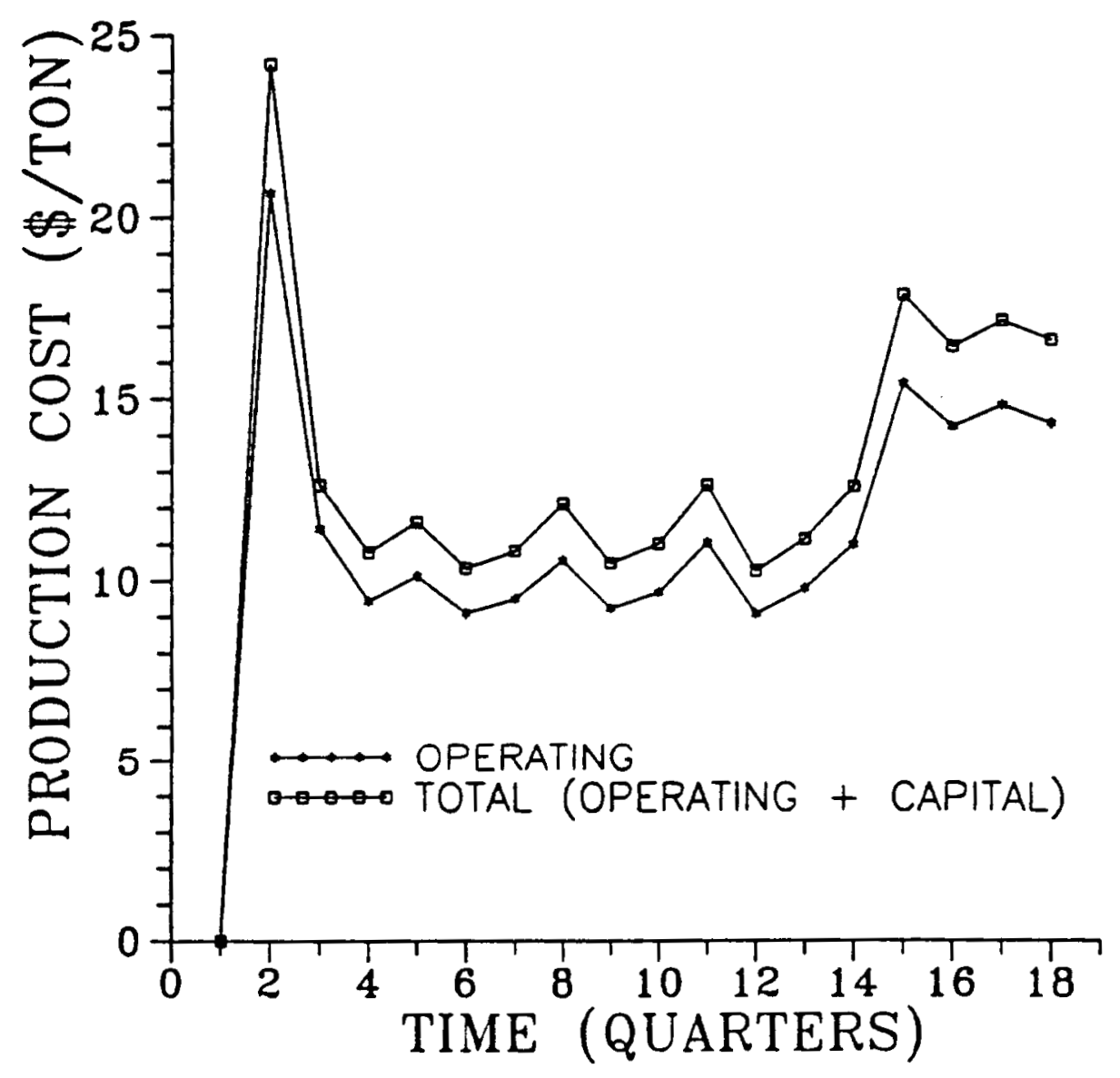


FIGURE 3 - QUARTERLY OPERATING AND TOTAL MINING COSTS
i4 RETORT DEMONSTRATION PROJECT

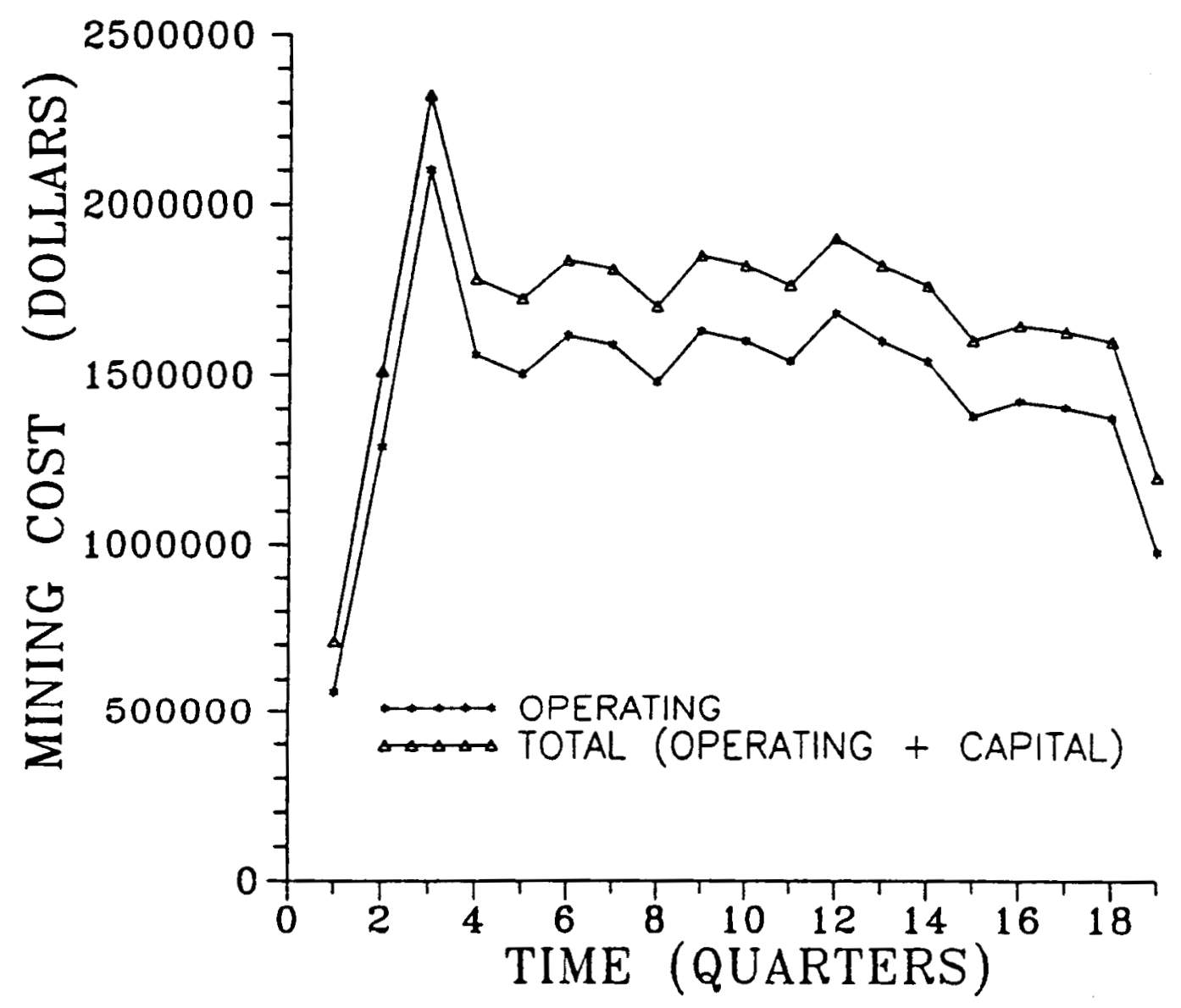


FIGURE 4 - CUMULATIVE OPERATING AND TOTAL COST PER TON 14 RETORT DEMONSTRATION PROJECT

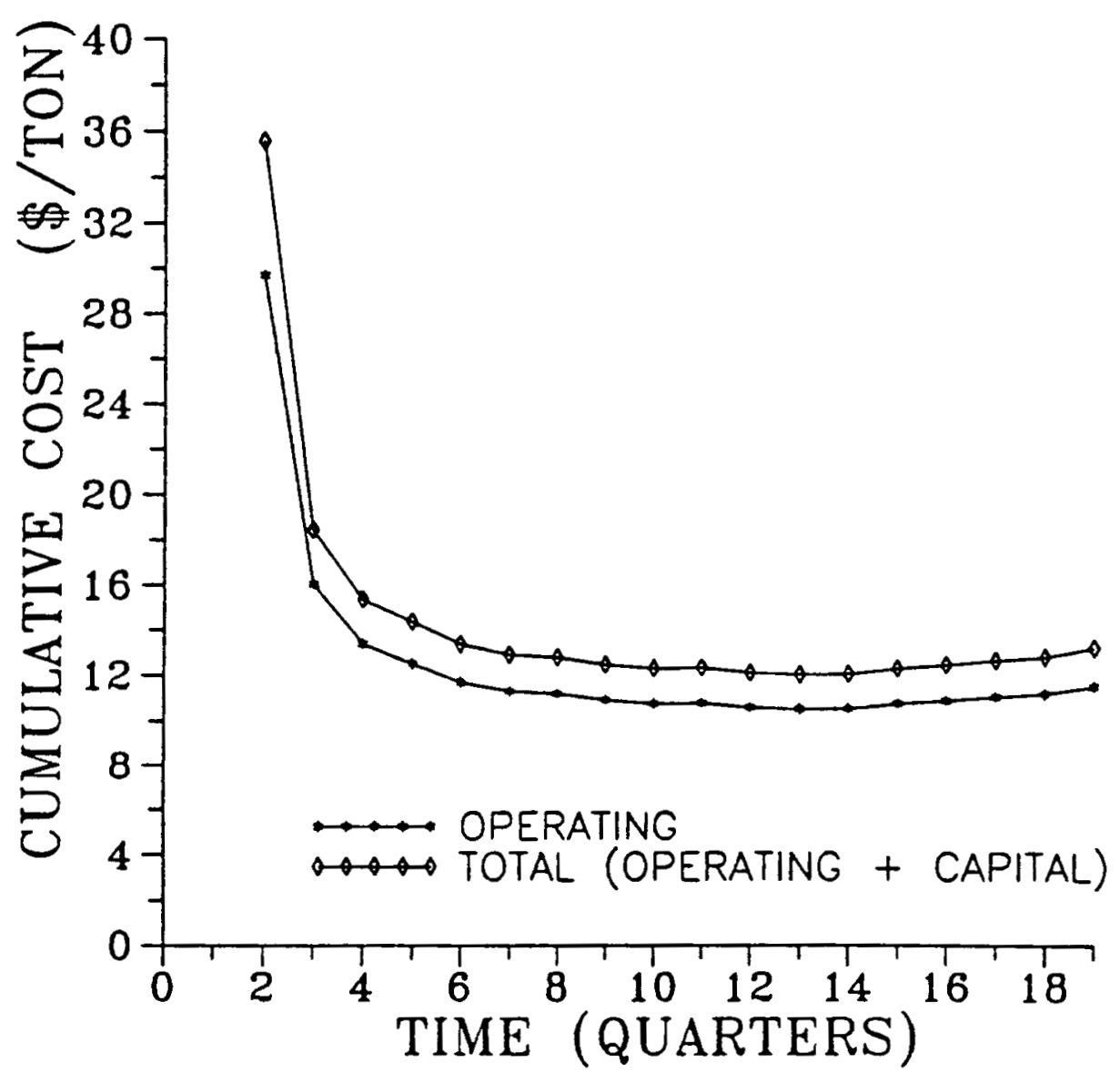


J. F. T. AGAPITO \& ASSOCLATES, NC. CONSULTING GEOTECHNCNL MO MINING ENGINEEAB

IIS HORIZON DRIVE, SUITE 340

GRAND JUNCTION, COLORADO 81506

July 6, 1989

Dr. Ray Zahradnik

Occidental Oil Shale, Inc.

1250 South Lincoln Avenue, Suite I-5

P. O. Box 880408

Steamboat Plaza

Steamboat Springs, CO 80488

Re: Occidental C-b; 17 Retort Demonstration Project, Mining Costs

Dear Ray:

This letter summarizes our estimate of costs to mine access drifts and the upper, intermediate, lower and product levels for a 17 retort demonstration project from the existing C-b service and production shafts. This estimate is based upon the same assumptions used in our previous study of the 14 retort case, discussed in our letter report to you on June 9, 1989. The 14 retort case was extended to 17 retorts at the request of Roger Moore.

The 17 retort case requires 64 months, or 7 months longer than estimated for 14 retorts. This rate is based upon optimization of the production process and equipment. Table 1 compares the production and cost values for the 17 and 14 retort cases. The three additional retorts results in a 3 to 4 percent decrease in cost per ton. Figure 1 shows the cumulative production versus time, and Figure 2 shows the variation of cost per ton on a quarterly basis. Production costs begin to rise after the 15 th quarter because production drops as the project winds down. A more detailed summary of the cost estimate is presented in the attached Table 2.

Steady state mining costs were estimated to be $\$ 9.80$ per ton by averaging operating cost per ton for the 3rd through 15th quarters when quarterly production ranged from 123,000 to 244,000 tons. After the 15th quarter, production rates begin to drop as the project winds down, and costs per ton begin to increase to the $\$ 13$ to $\$ 17$ per ton range. 
Dr. Ray Zahradnik

July 6, 1989

Page 2

Table 1 Comparison of 17 and 14 Retort Cases

\begin{tabular}{|c|c|c|}
\hline Ttem & 17 Retorts & 14 Retorts \\
\hline Production (tons) & $2,854,797$ & $2,414,222$ \\
\hline Total cost & $\$ 36,240,681$ & ". \\
\hline Total cost per ton & $\$ 12.69 \%$ & 1.18 .13 .23 \\
\hline Capital equipment & $4,313,997$ & $4,128,995$ \\
\hline Operating cost & $\$ 31,926,684$ & $.827,801,932$ \\
\hline Operating cost per ton & $=\$ 11.18$ & .8 .811 .52 \\
\hline
\end{tabular}

We look forward to discussing this estimate with you in more detail.

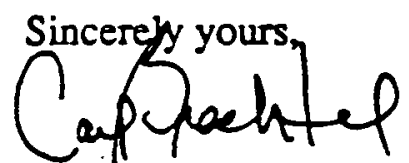

Carl E. Brechtel

Sr. Associate

CEB/klg

cc: Roger Moore 


\section{FIGURE 1 - CUMULATIVE PRODUCTION 17 RETORT CASE}

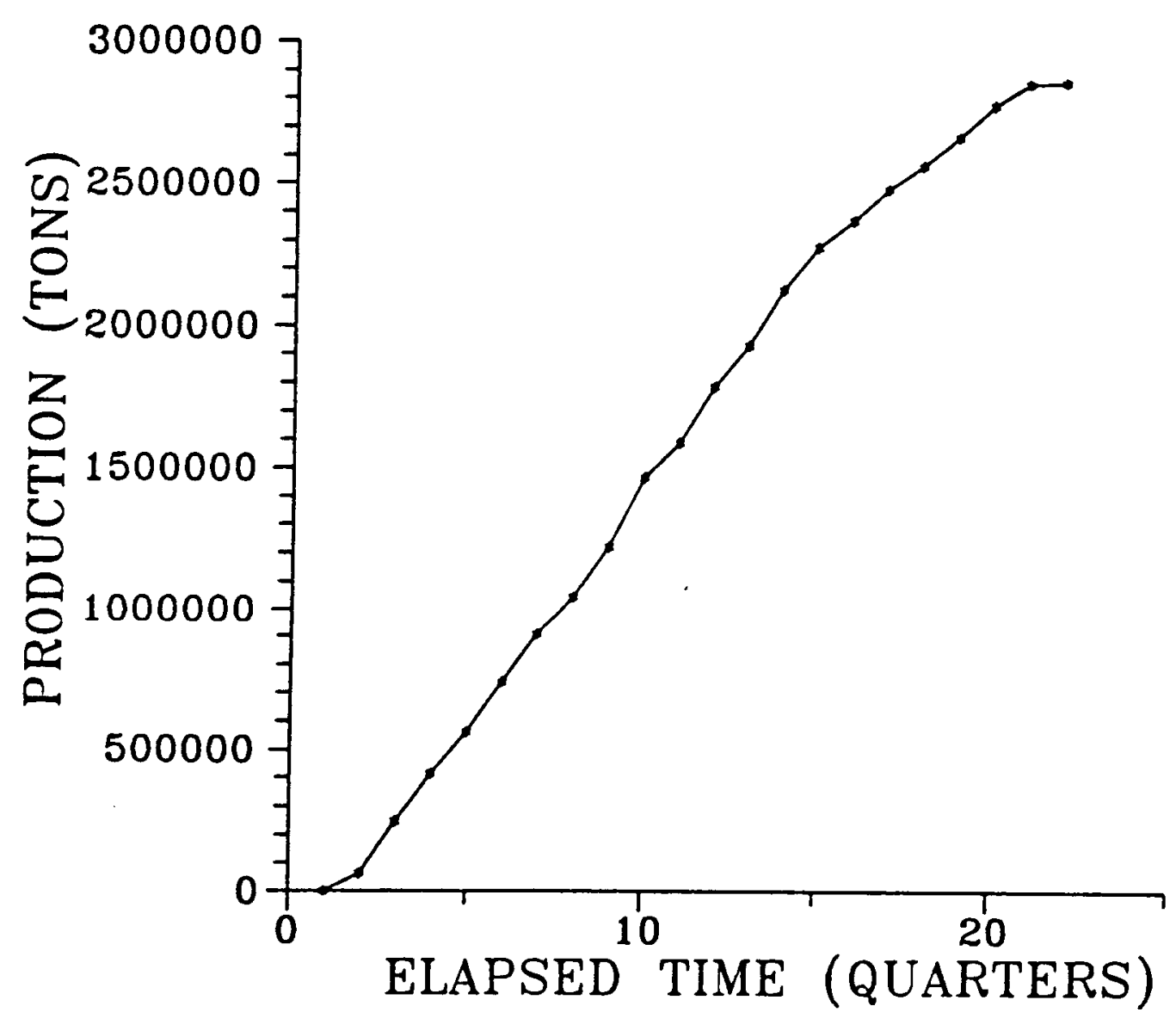




\section{FIGURE 2 - COMPARISON OF NORMALIZED COST 17 RETORT CASE}

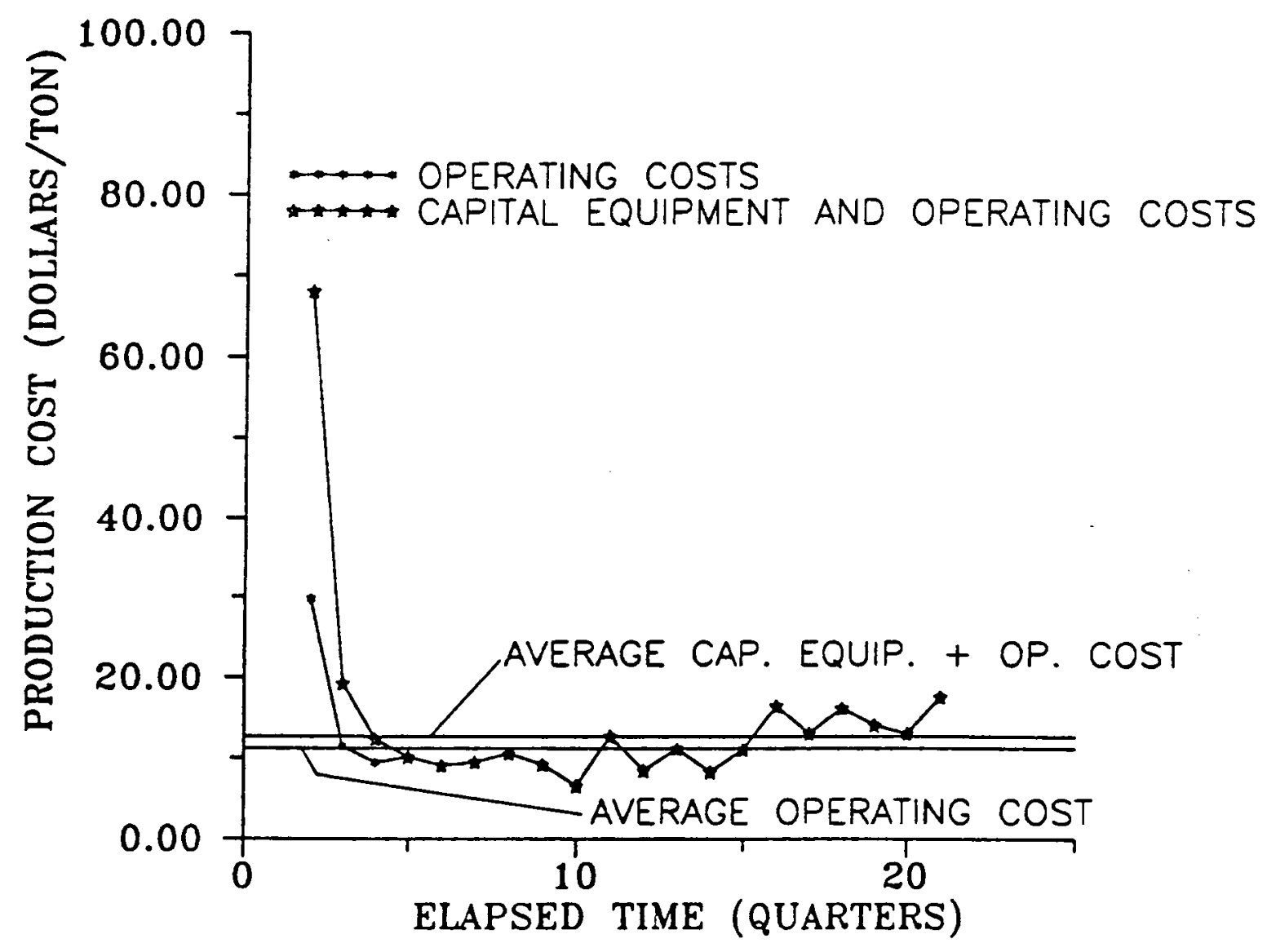




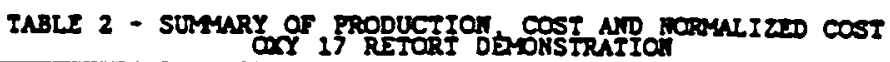

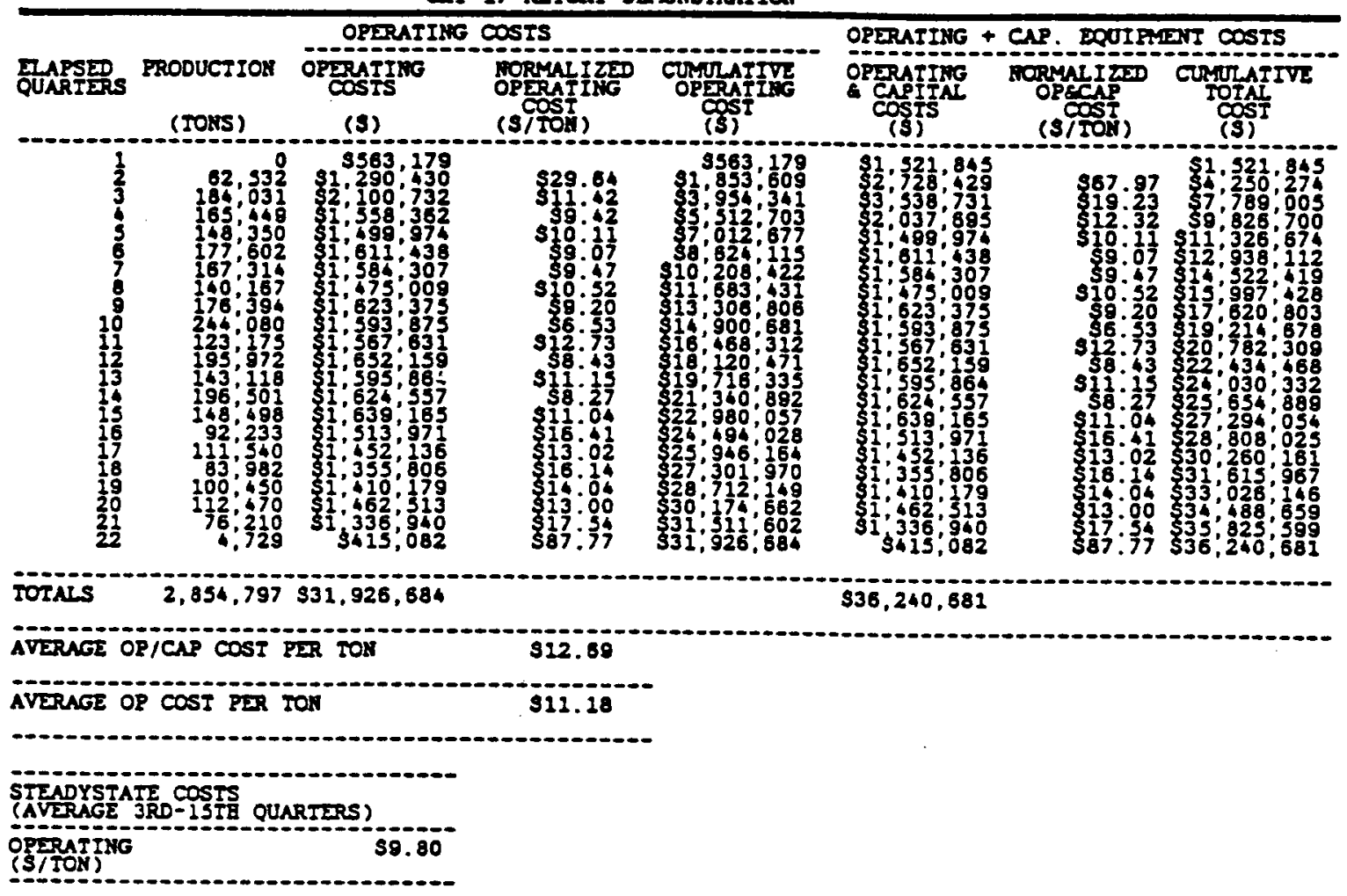




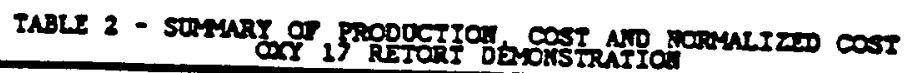

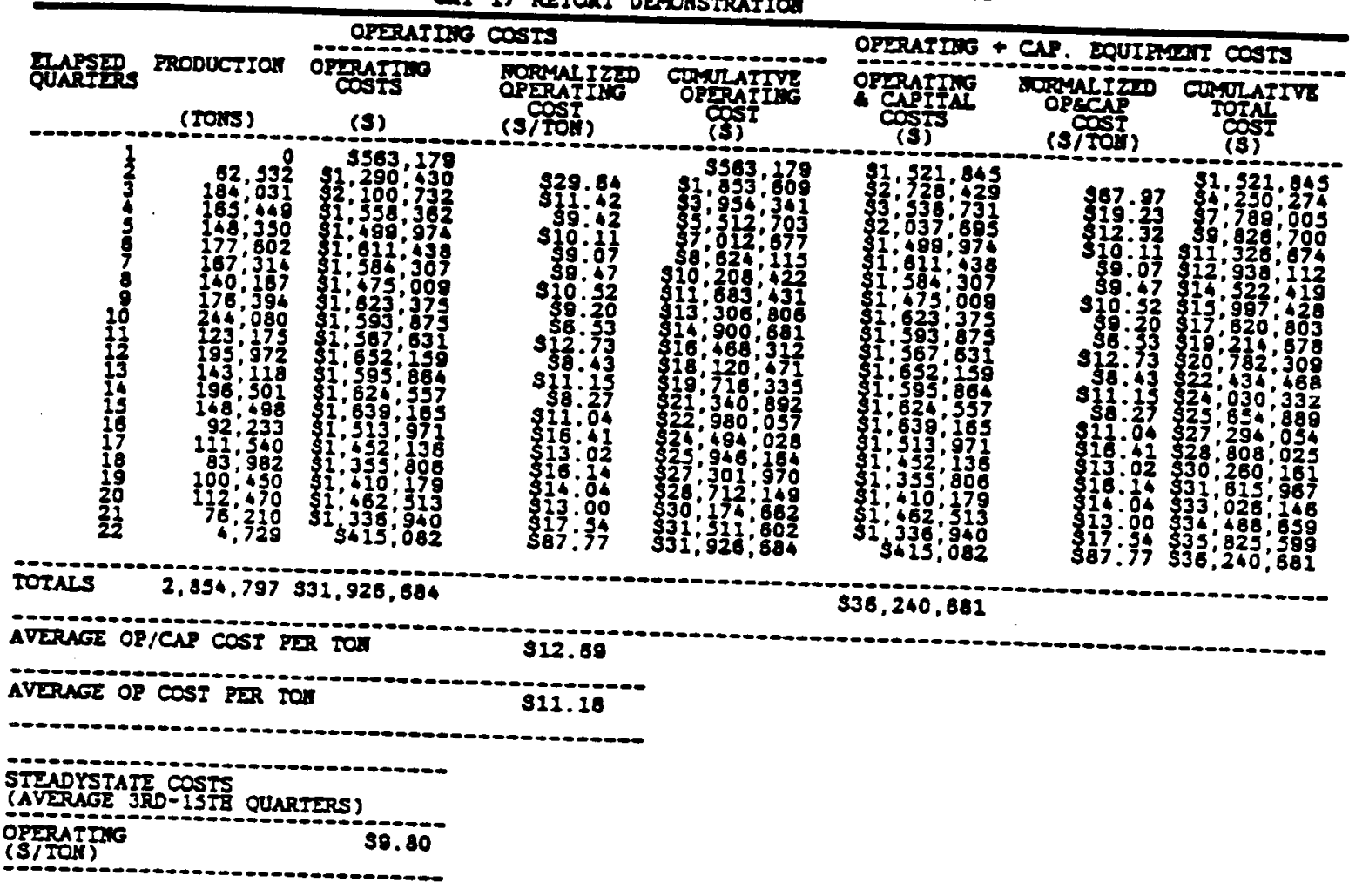




\section{COMPARISON OF NORMALIZED COST 17 RETORT CASE}

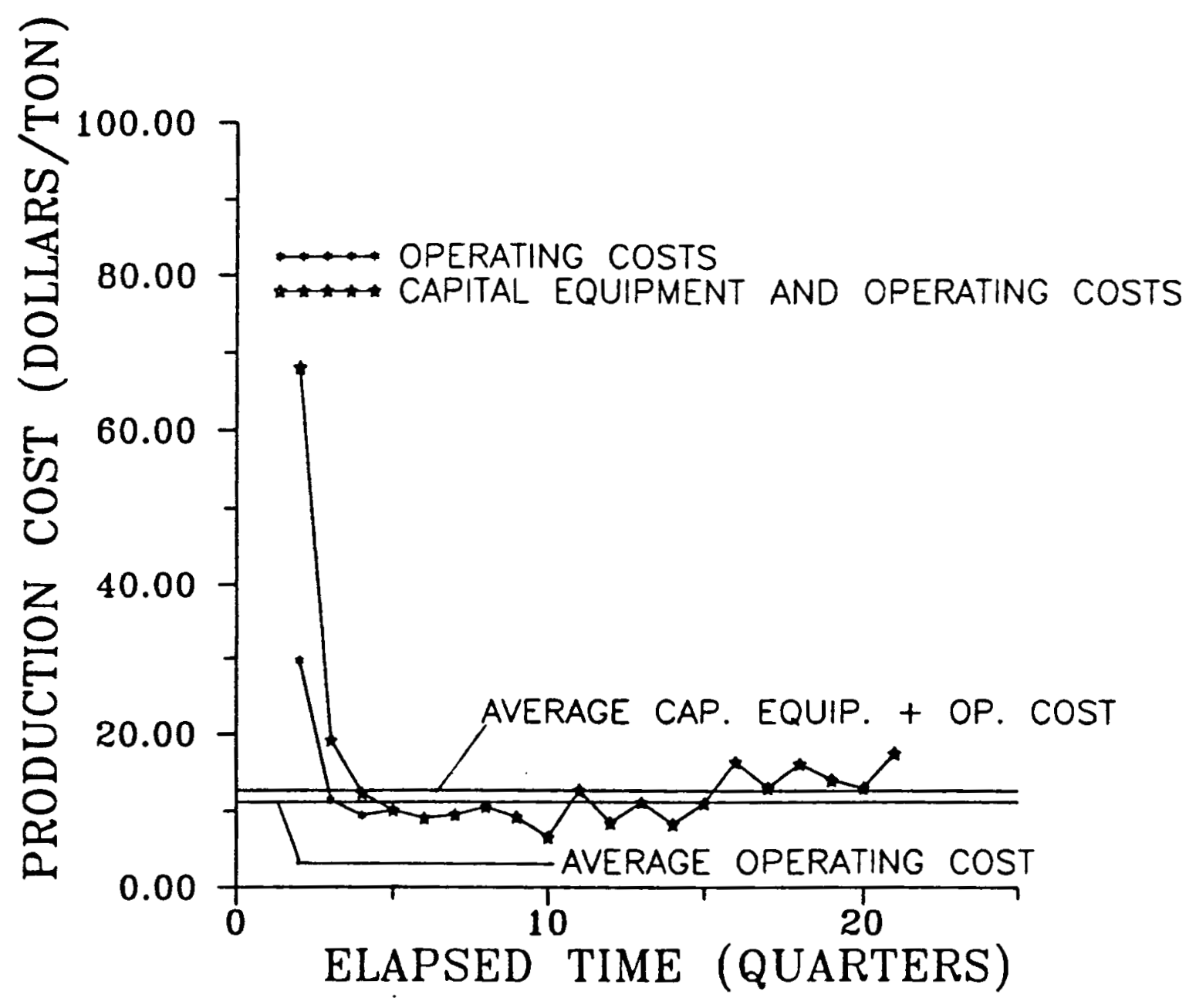




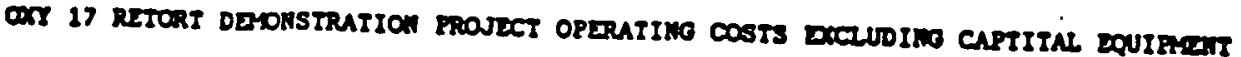
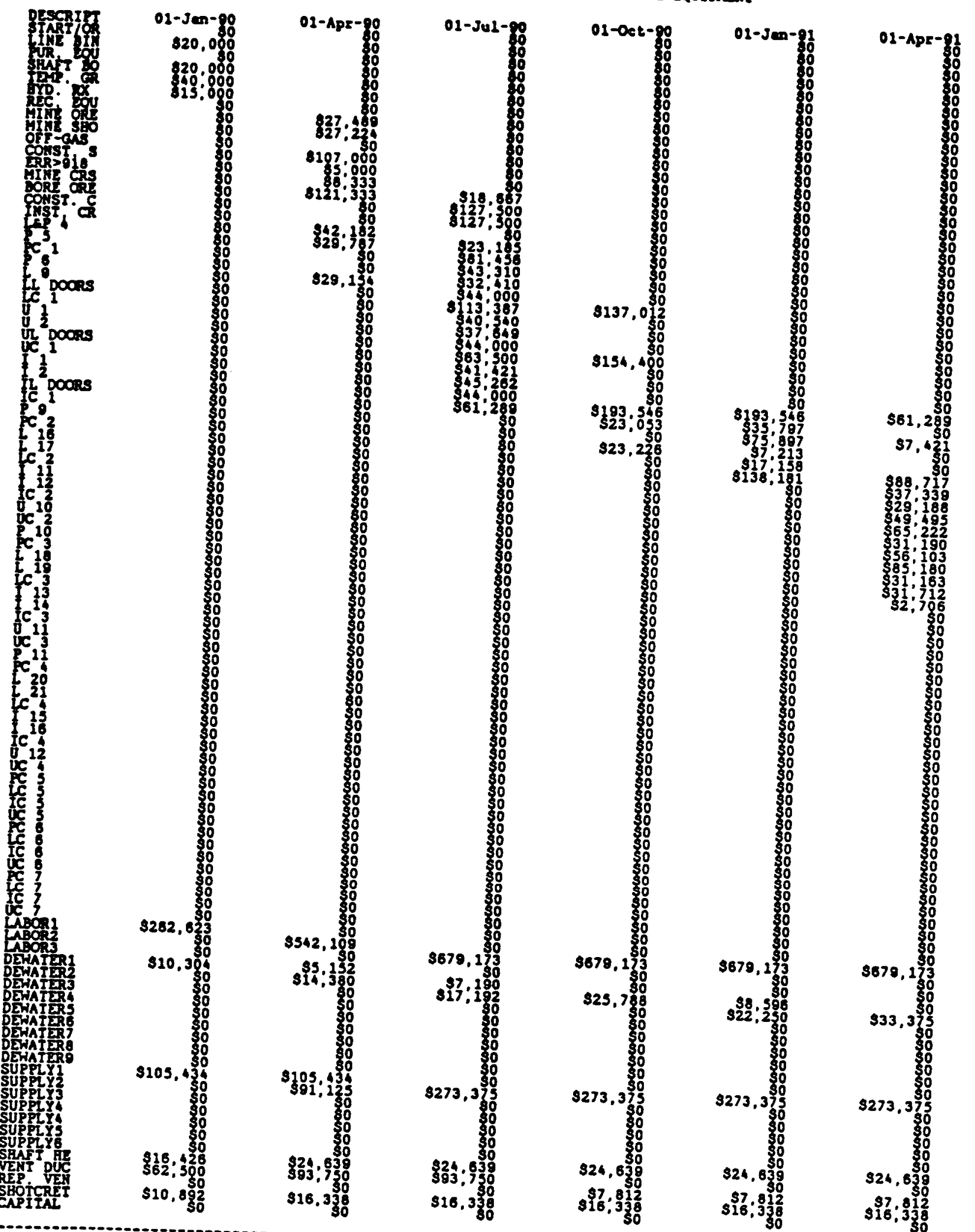

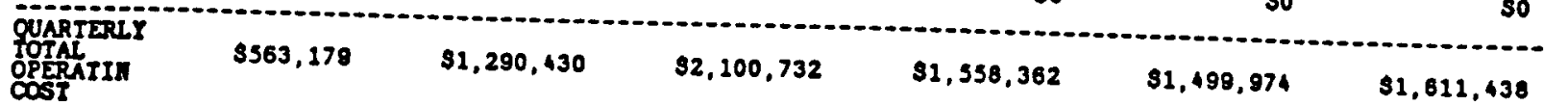

\section{TOTAL}

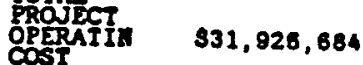




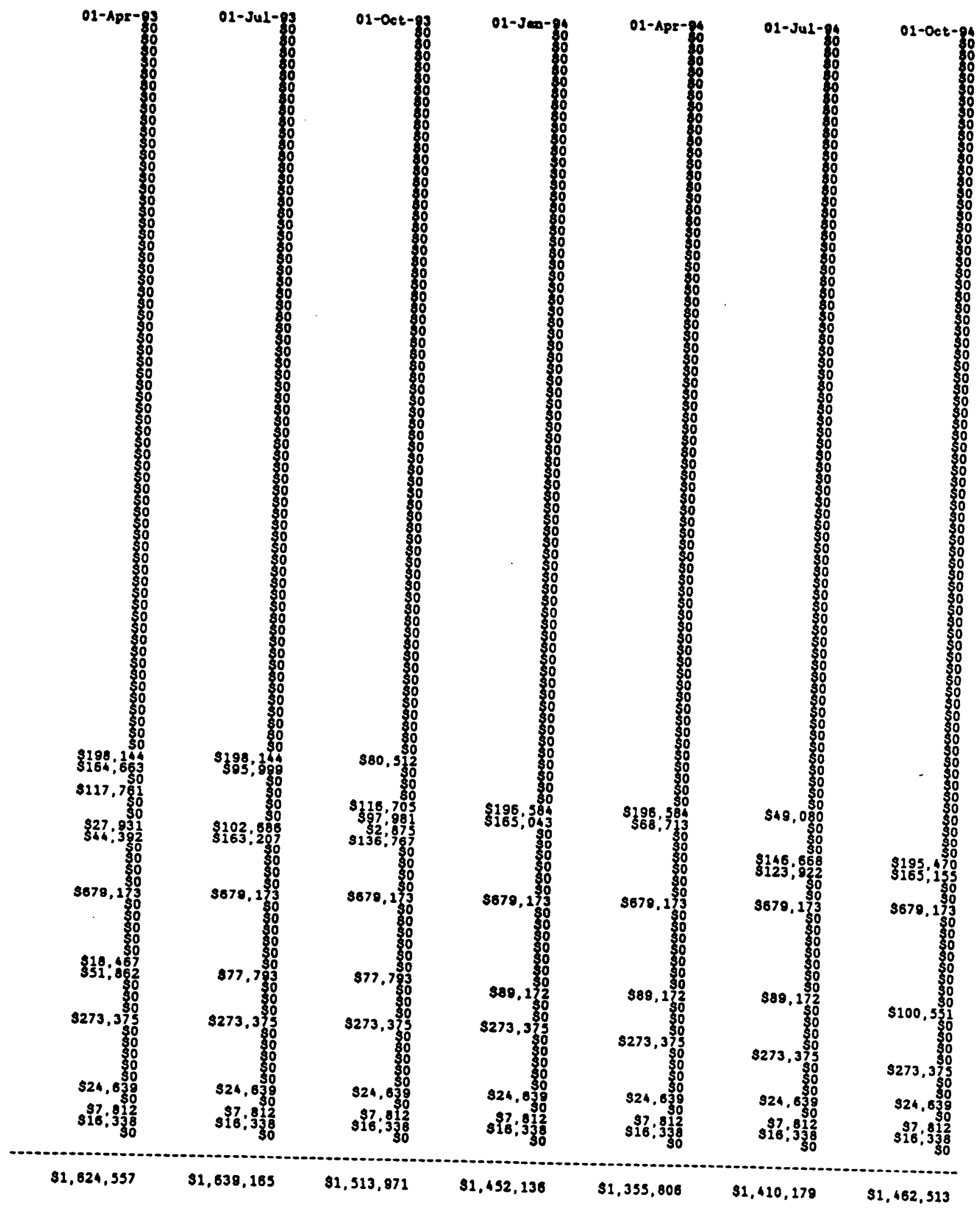



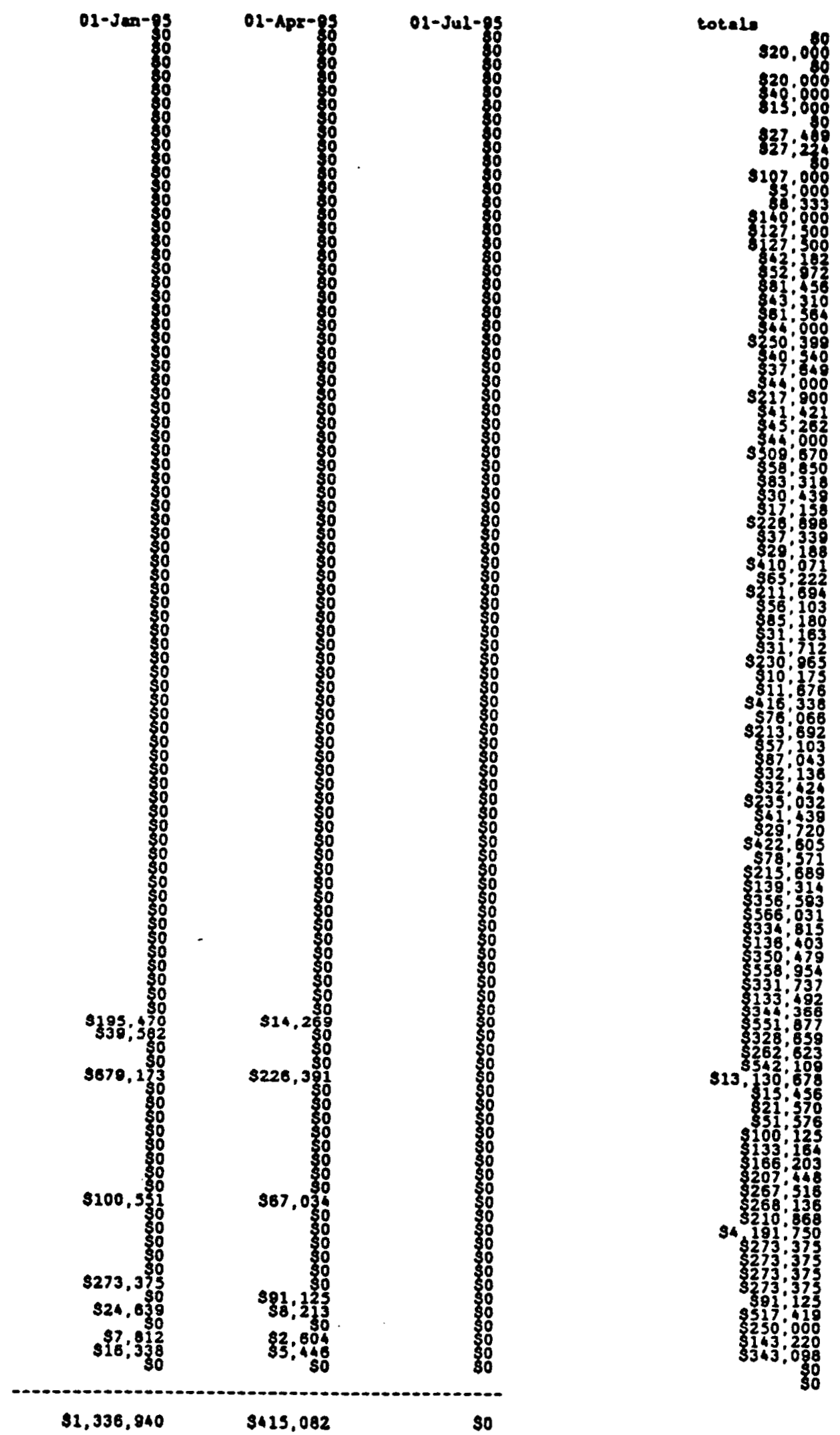


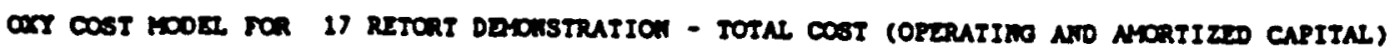

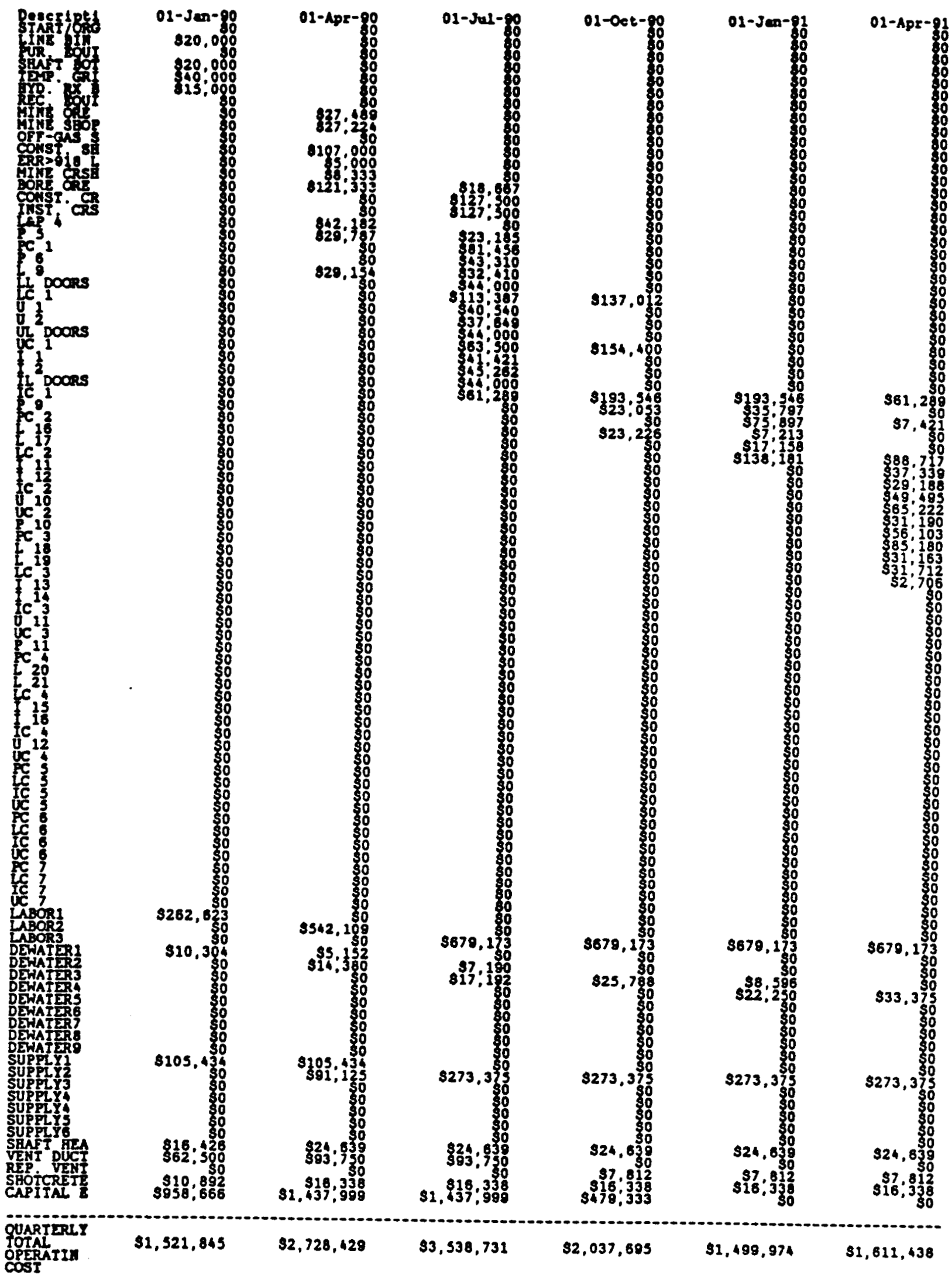

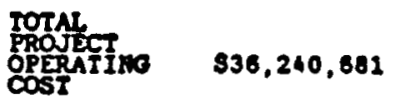




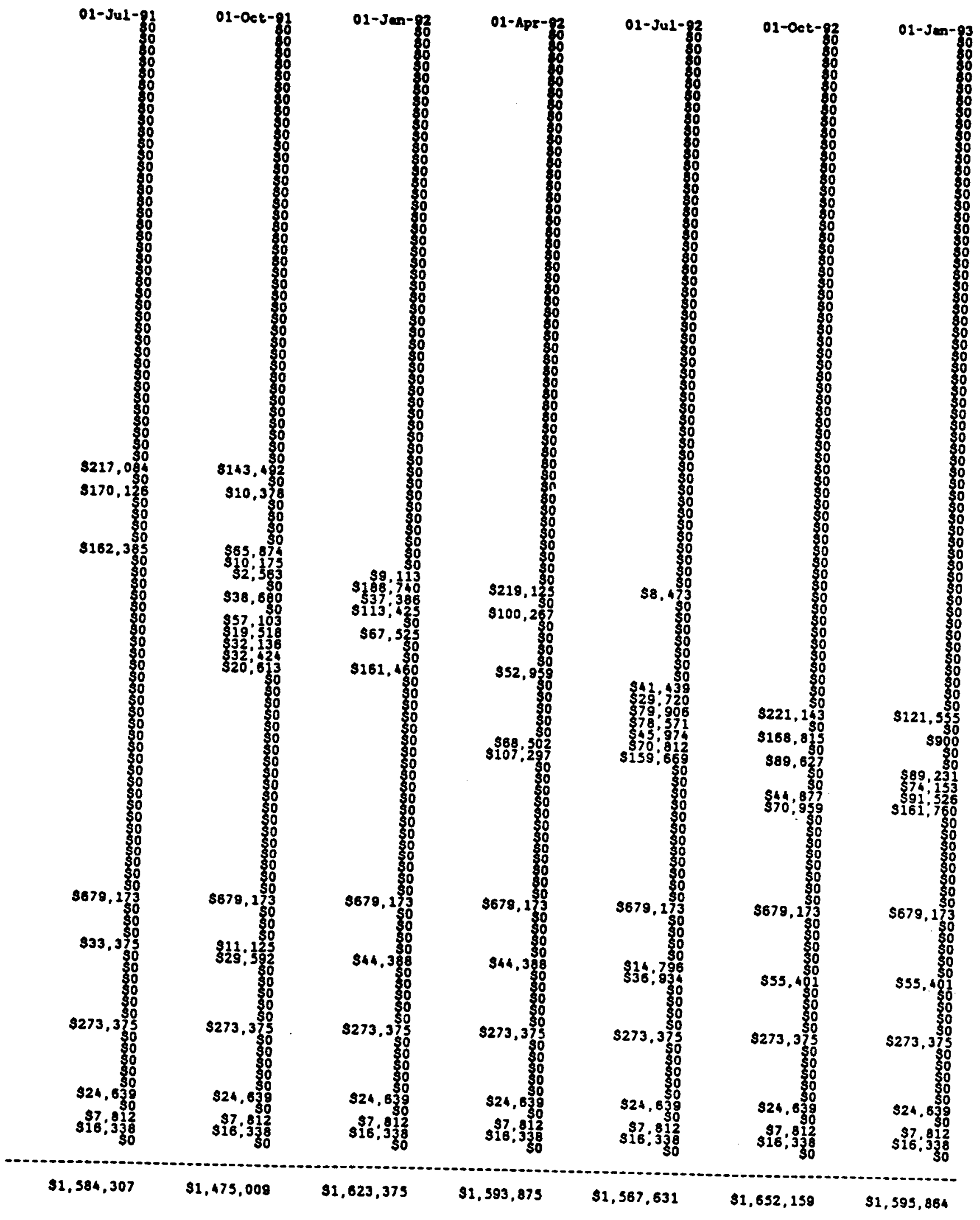




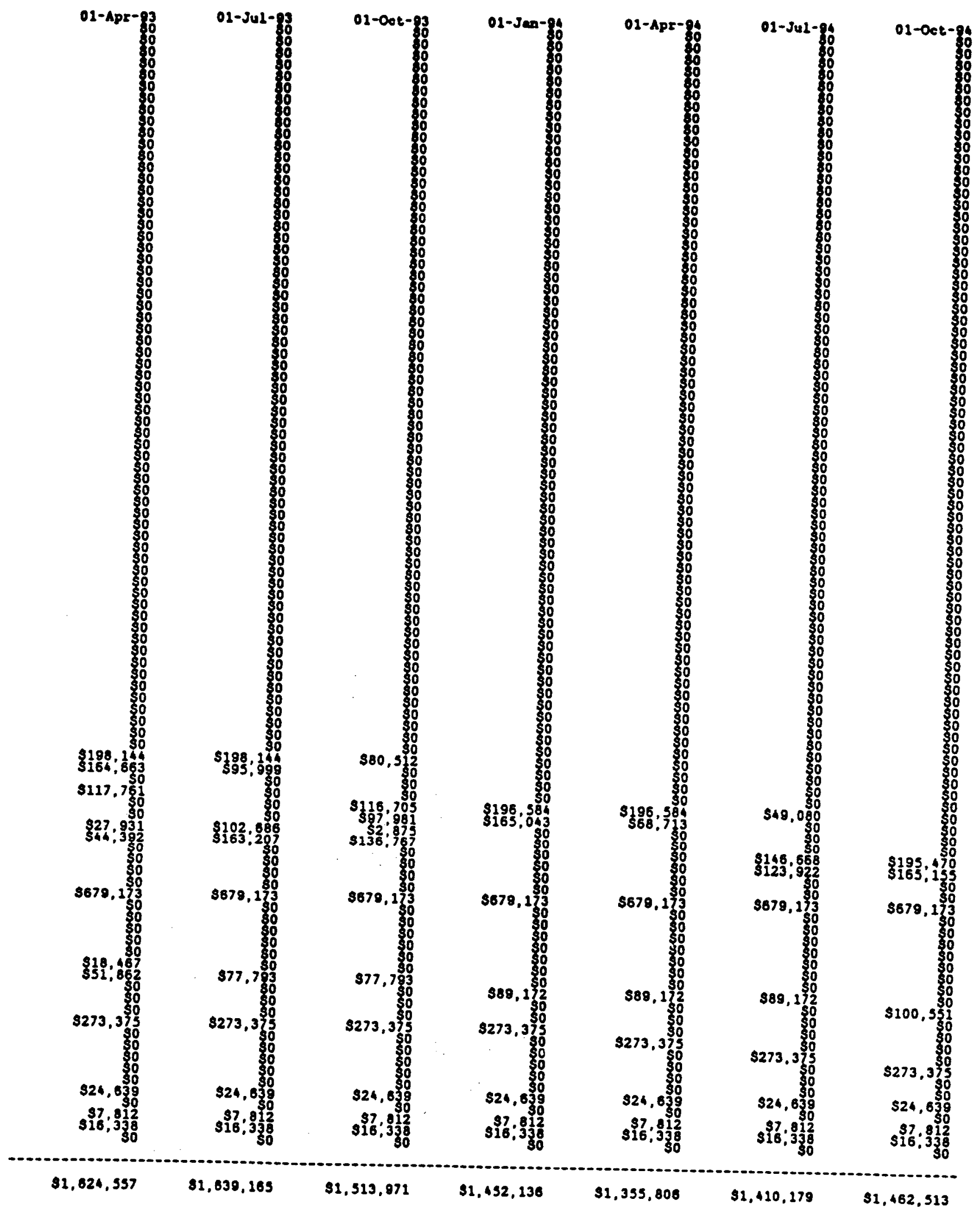



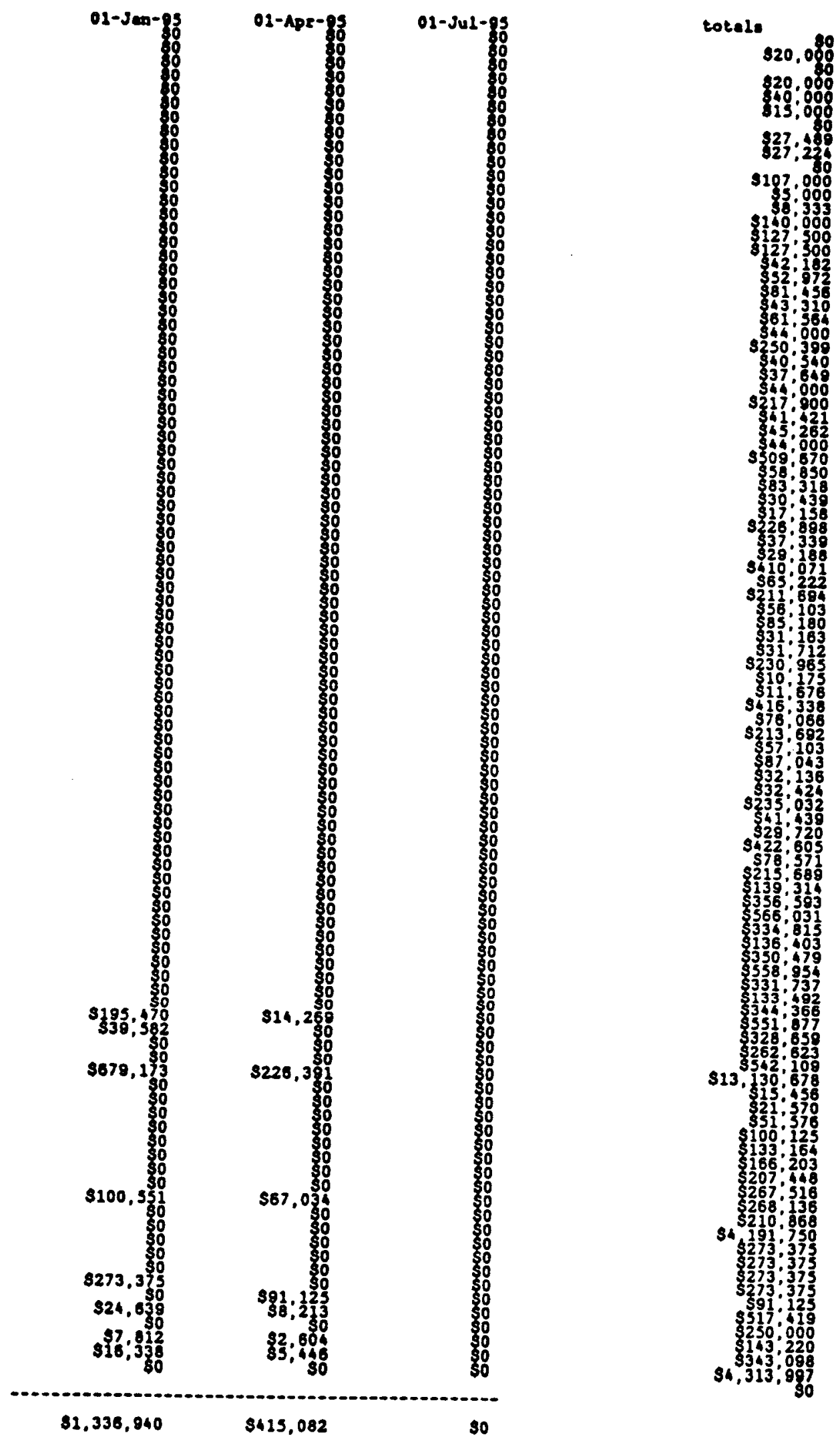


\section{CUMULATIVE PRODUCTION \\ 17 RETORT CASE}

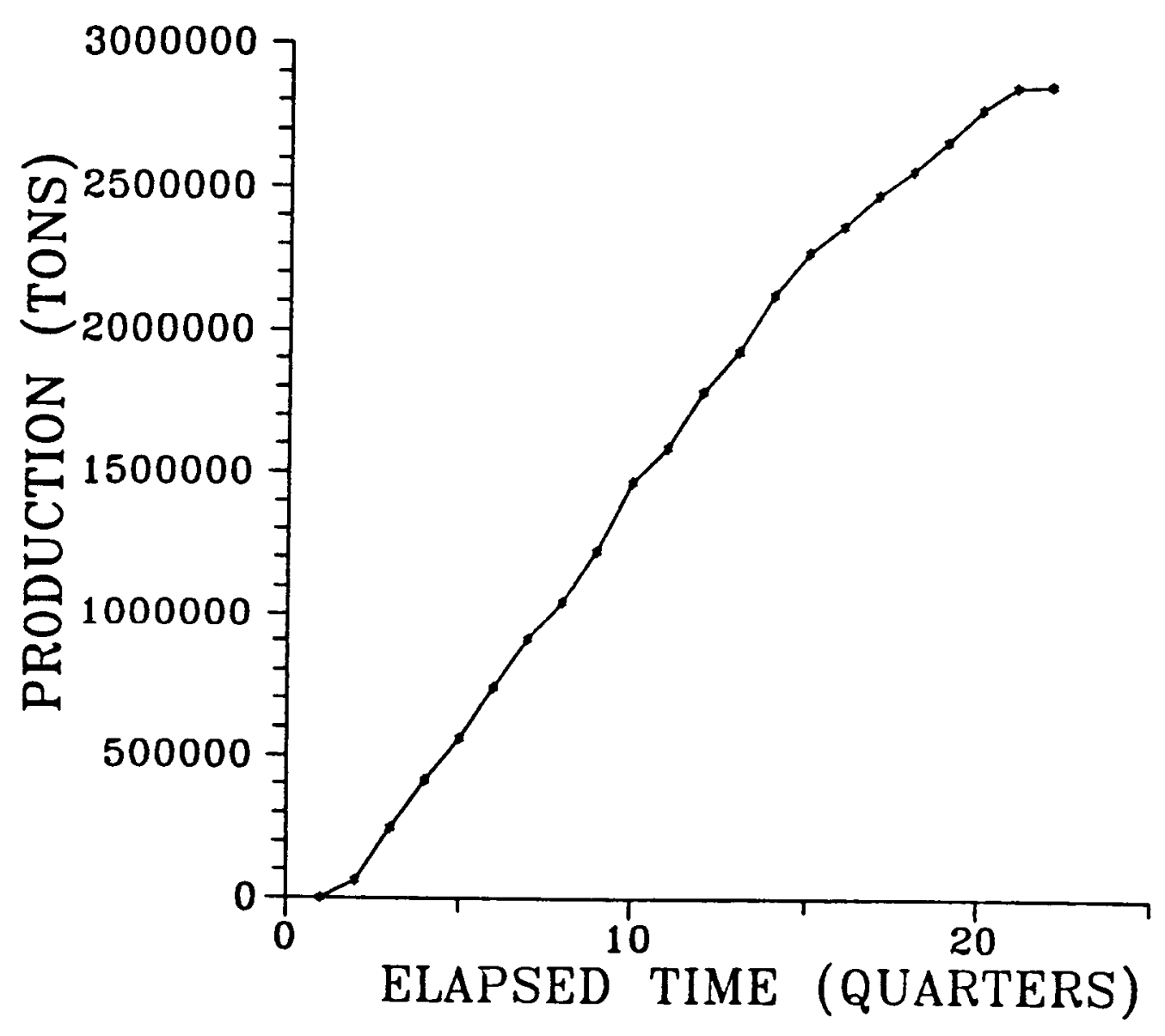




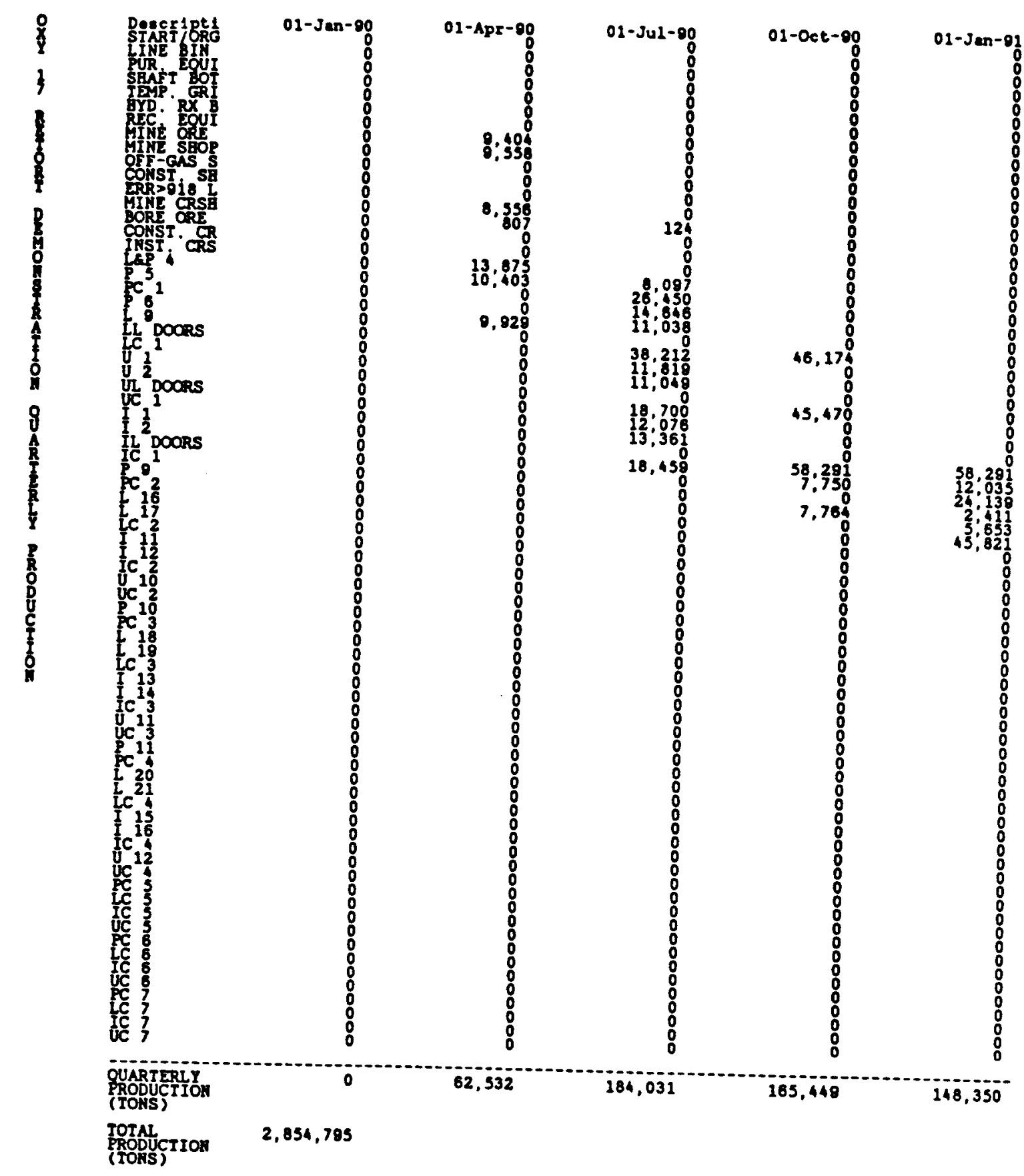




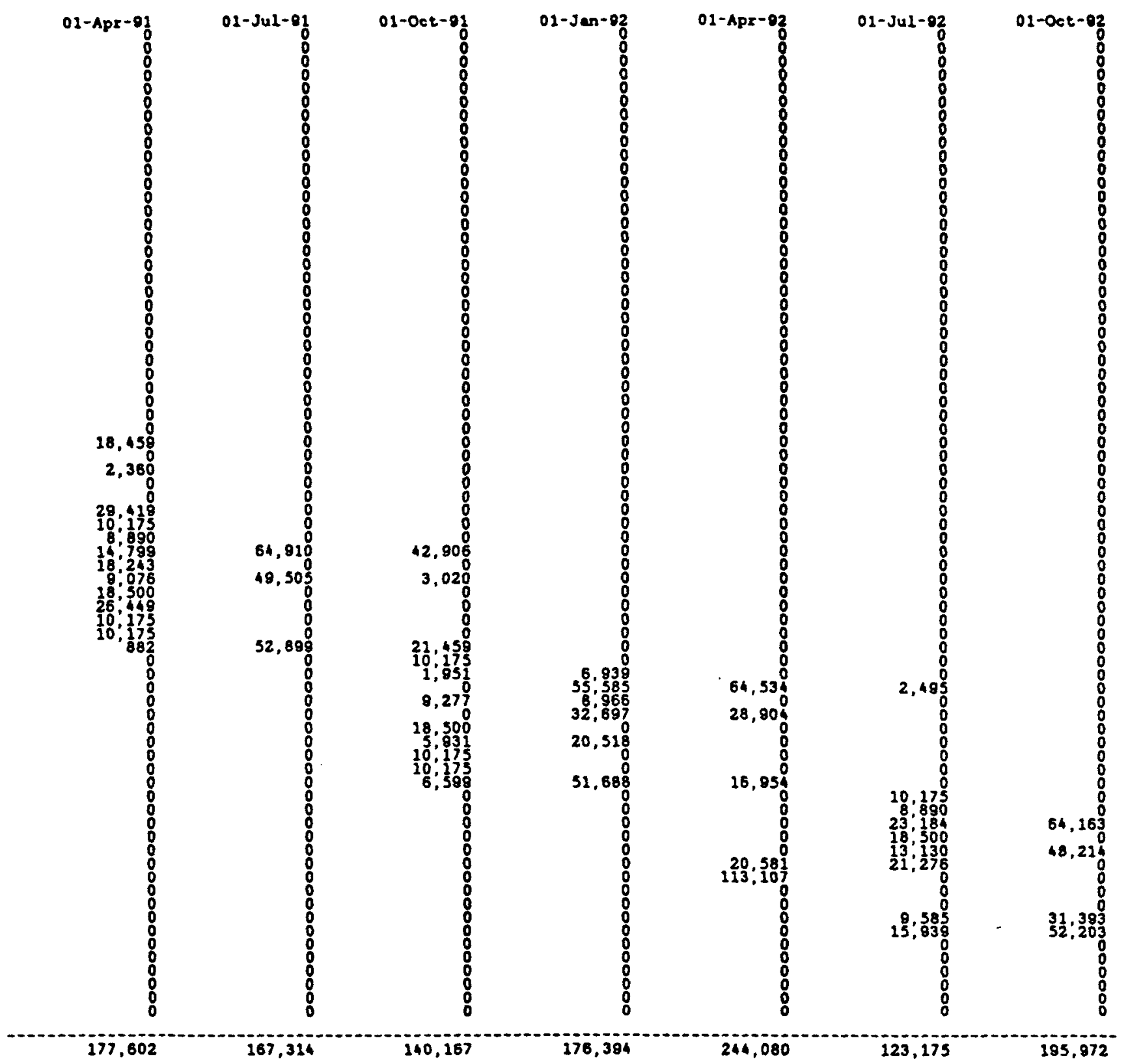




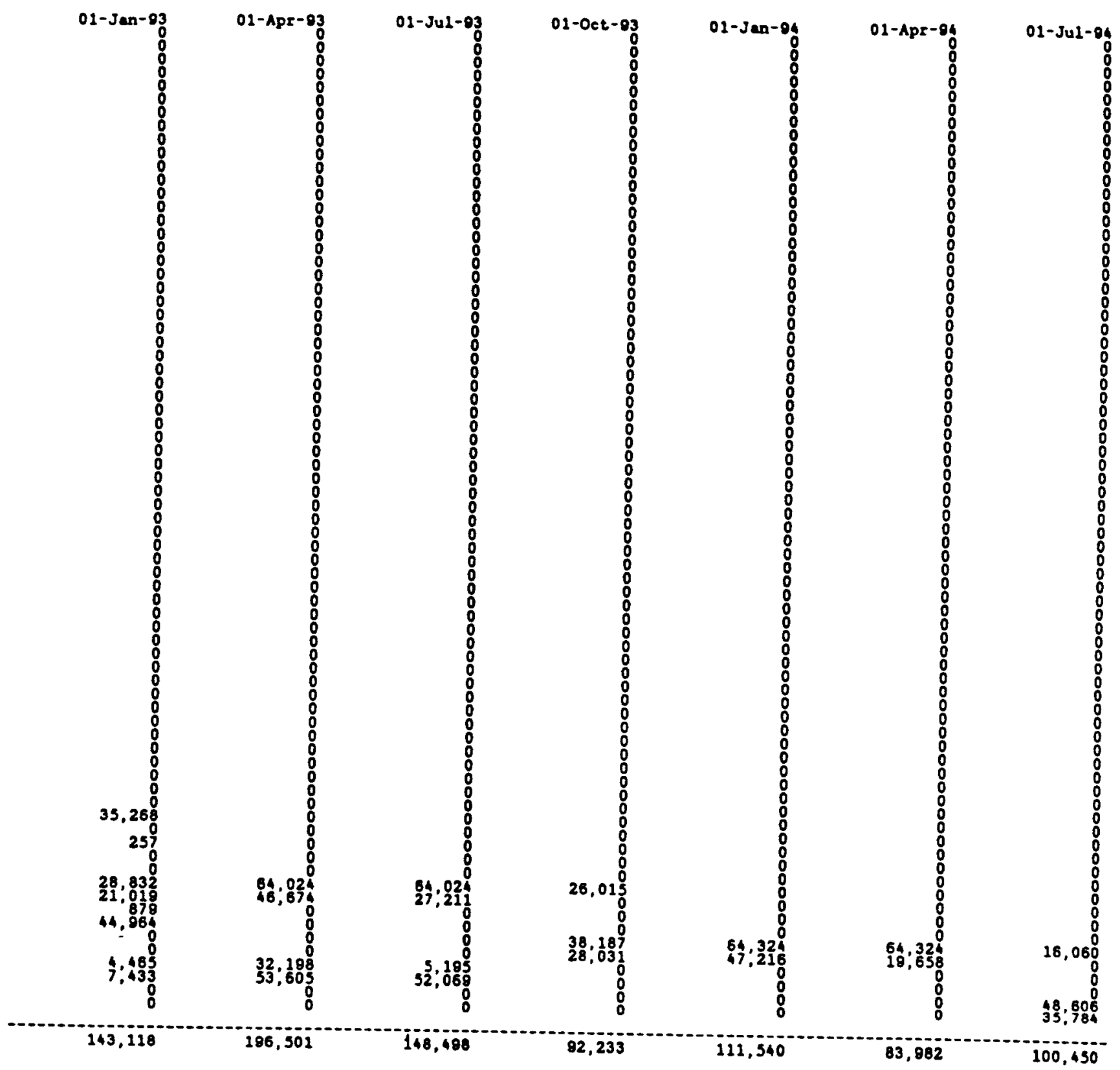




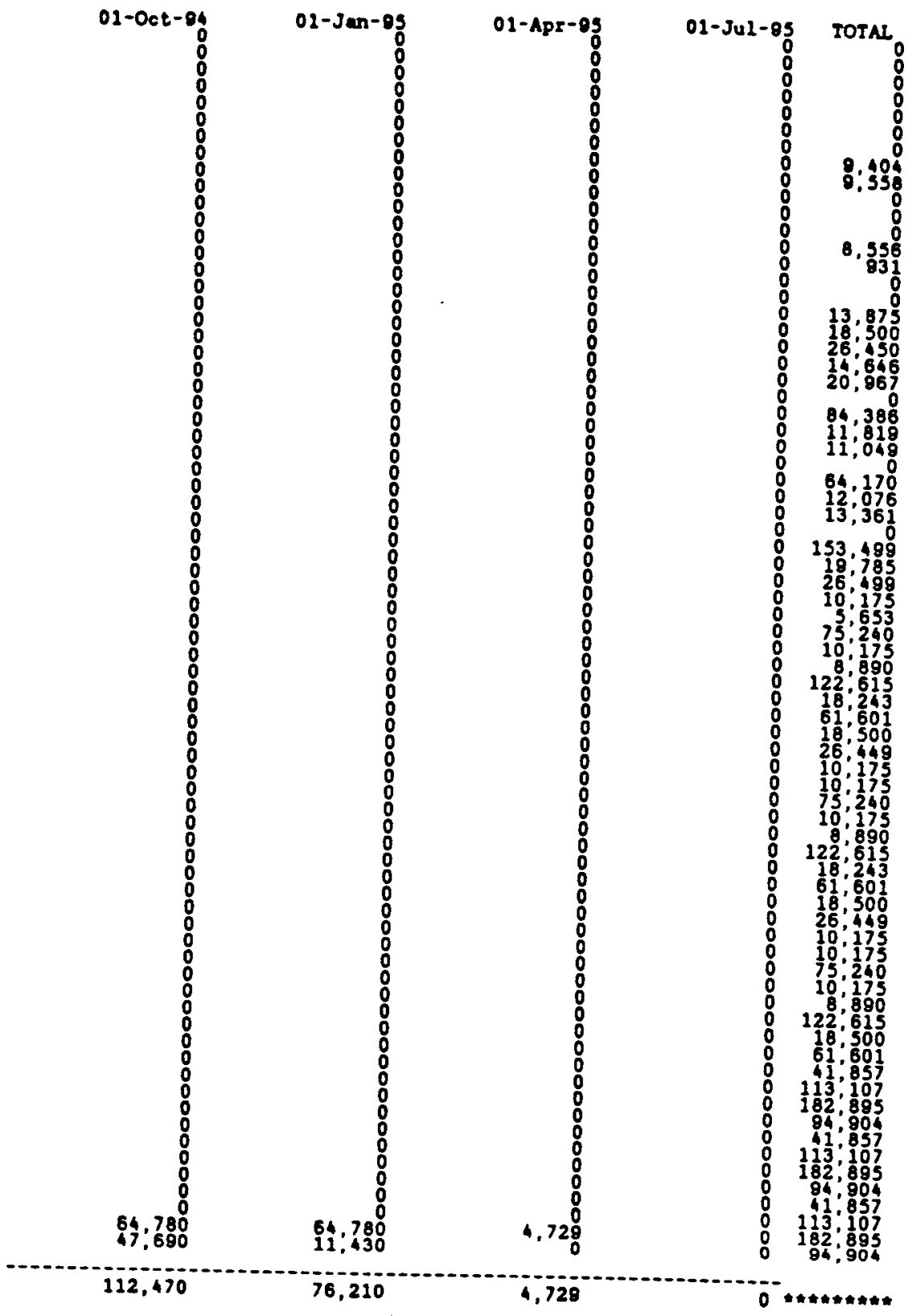




\section{J. F. T. AGAPITO \& ASSOCIATES, INC. CONSULTINO GEOTECHINCN NO MINING ENGINEEAS \\ 715 HORIZON DRIVE, SUITE 340 \\ GRAND JUNCTION, COLORADO 81506}

July 10,1989

Dr. Ray Zahradnik

Occidental Oil Shale, Inc.

1250 South Lincoln Avenue, Suite I-5

P. O. Box 880408

Steamboat Plaza

Steamboat Springs, CO 80488

Re: Occidental C-b; Estimated Steady State Mining Cost for Commercial Scale

Dear Ray:

This letter presents the results of our estimate of the steady state mining costs to excavate upper, lower, intermediate and product levels from the existing C-b shaft facilities. The estimate is based upon plans for developing the first retorts at the north end of the C-b tract, as per the Cathedral Bluffs Shale Oil Co. drawings that are listed in the table in Attachment A.

The costs are limited to the underground activities required to complete retort development excavations for input to Roger Moore's overall project cost estimate.

Costs include:

- shaft station developments and support facilities (shops, storage, loading, power centers, and pump stations, etc.)

- $\quad$ mining equipment (LHD, trucks, bolters, scalers, etc.)

- $\quad$ ore transport (feeder breakers, conveyors)

- face ventilation

- $\quad$ ore passes, off-gas shaft, and ventilation exhaust shaft

- ramps between levels

- main entries to panels on each level

- face ventilation equipment and ventilation control structures

- break through to V-E shaft on panel advance

- $\quad$ supplies, maintenance and power 
Dr. Ray Zahradnik

July 10, 1989

Page 2

- dewatering

Specific underground operations that are not included are:

- rubbilization,

- hoisting of ore,

- retorting operations, and

- $\quad$ surface facilities, operations and support.

We have also assumed that the underground planning and engineering activities will be carried out by an overall site group that is separate from the mining production operation. Main ventilation equipment was not included because OXY has a large main fan in storage. Sales taxes were not considered on materials or equipment purchases.

The results of the estimate are listed in Table 1 . The total cost per ton was estimated at $\$ 11.66$ by distributing the capital equipment and development costs over five years (3.8 panels, 136 retorts). Average operating costs during the five year period were predicted to be $\$ 9.62$ per ton. These costs are projected at constant value dollars. Tables containing more detailed breakdowns of the estimated costs are presented in Attachment B.

Table 1 Estimated Mining Production Costs for 27.5 Retorts per Year with Capital Costs Amortized over Five Years (3.8 Panels, 36 Retorts per Panel)

\begin{tabular}{|c|c|c|c|c|c|}
\hline 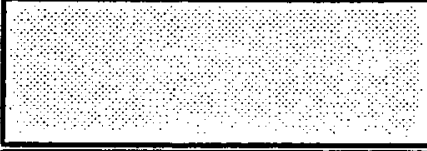 & $\begin{array}{c}\text { Amortization } \\
\begin{array}{c}\text { Period } \\
\text { (years) }\end{array}\end{array}$ & $\begin{array}{l}\text { Estimated } \\
\text { Cost }{ }^{*} \\
(\$)\end{array}$ & $\begin{array}{l}\text { Annual } \\
\text { Production } \\
\text { (tons) }\end{array}$ & $\begin{array}{l}\text { Mining } \\
\text { Cost } \\
\text { (\$/ton) }\end{array}$ & $\begin{array}{l}\text { Annual } \\
\text { Cost } \\
\text { (\$) }\end{array}$ \\
\hline Capital equipment & 5 & $\$ 25,513,000$ & & & $\$ 5,102,600$ \\
\hline Capital development & 5 & $\$ 22,320,000$ & & & $\$ 4,464,000$ \\
\hline Labor & 1 & & 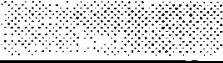 & & $\$ 14,254,300$ \\
\hline Direct mining & & & $4,700,000$ & $\$ 3.06$ & $\$ 14,382,000$ \\
\hline Indirect mining & 1 & $\$ 16,586,000$ & & & $\$ 16,586,000$ \\
\hline Subtotals & & & $4,700,000$ & & $\$ 54,788,900$ \\
\hline Total cost per ton $(\$ /$ ton $)$ & & & & $\$ 11.66$ & \\
\hline $\begin{array}{l}\text { Operating cost per ton } \\
(\$ / \text { ton })\end{array}$ & & & & $\$ 9.62$ & \\
\hline
\end{tabular}

* Constant dollars 
Dr. Ray Zahradnik

July 10, 1989

Page 3

The steady state costs are expected to lie between $\$ 9.62 /$ ton and $\$ 11.66 /$ ton because the commercial operation requires continued installation of some items considered capital in our start-up analysis. This includes off-gas shafts, ventilation exhaust shafts, main entry developments and major equipment replacement.

Generation of the commercial scale estimate was not supported by the level of detail used in our analysis of the 14 and 17 retort demonstration project.

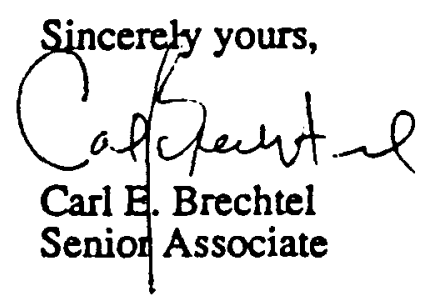

\section{$\mathrm{CEB} / \mathrm{klg}$}

cc: Roger Moore 


\title{
ATTACHMENT A
}

\author{
C-b Drawings Used in the Analysis
}


CATHEDERAL BLUFFS SHALE OIL COMPANY DRAWINGS USED IN ANALYSIS DRAWING TITLE

NO.

$\begin{array}{ll}\text { ND-0515-M } & \text { INITIAL MINE AND PLANT PILIAR LAYOUT } \\ \text { ND-0507-M } & \text { AIR \& UPPER LEVEL STATION DEVELOPMENT } \\ \text { ND-0508M } & \text { INTERMEDIATE LEVEL STATION DEVELOPMENT } \\ \text { ND-0509-M } & \text { LOWER LEVEL STATION \& RAMP DEVELOPMENT } \\ \text { ND-0511-M } & \text { MIS UPPER VOID LEVEL } \\ \text { ND-0512-M } & \text { MIS INTERMEDIATE VOID LEVEL } \\ \text { ND-0514-M } & \text { LOWER VOID/PRODUCT LEVEL } \\ \text { ND-0516-M } & \text { MIS RETORT BOTTOM DRAWPOINT DESIGN } \\ \text { TD-0505-M } & \text { MIS VENTILATION PLAN UPPER LEVEL } \\ \text { TD-0505-M } & \text { MIS VENTILATION PLAN INTERMEDIATE LEVEL } \\ \text { TD-0506-M } & \text { MIS VENTILATION PLAN LOWER LEVEL }\end{array}$




\section{ATTACHMENT B}

Mine Labor, Indirect, Capital and Direct Cost Estimates 
TABLE B1 ESTIMATED CB MINING OPERATIONS LABOR COSTS

\begin{tabular}{lllr}
\hline $\begin{array}{c}\text { NUMBER } \\
\text { OF } \\
\text { STAFF }\end{array}$ & JOB TITLE & SALARY & ANNUAL \\
\hline & MINE MANAGER & 60000 & \\
1 MINE MNGINEER & 40000 & $\$ 84,000$ \\
2 MINE ENGIN TECH & 25000 & $\$ 112,000$ \\
4 ENGINEER TE & $\$ 140,000$ \\
2 SECRETARY & 12000 & $\$ 33,600$ \\
3 MAINT SUPT & 35000 & $\$ 147,000$ \\
3 MINE SUPT & 40000 & $\$ 168,000$ \\
6 SHIFT FOREMAN & 35000 & $\$ 294,000$ \\
6 MAINT FORMAN & 35000 & $\$ 294,000$ \\
\hline
\end{tabular}

27 OVERHEAD \& SALARY

$\$ 1,272,600$

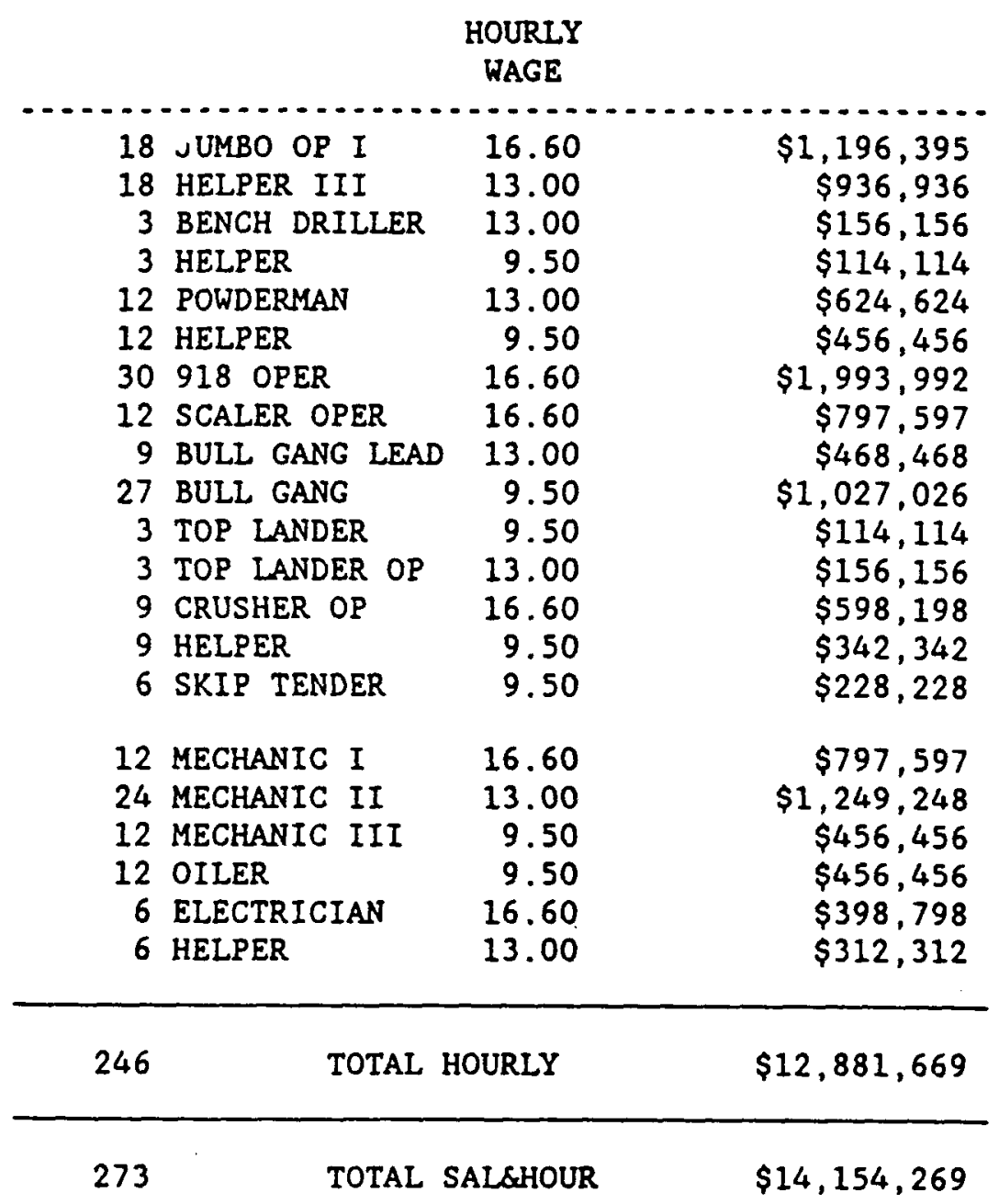


TABLE B2 CB INDIRECT UNDERGROUND MINING OPERATING COSTS

\begin{tabular}{|c|c|c|c|}
\hline & & & $\begin{array}{l}\text { DOLLARS } \\
\text { ER MONTH }\end{array}$ \\
\hline 0 & WATER TRUCK & $20 \$ / \mathrm{HR}$ & $\$ 6.000$ \\
\hline 0 & FUEL TRUCK & $20 \$ / \mathrm{HR}$ & $\$ 18,000$ \\
\hline 0 & MECH TRUCK & $20 \$ / \mathrm{HR}$ & $\$ 48,000$ \\
\hline 0 & COMPRESSOR & $20 \$ / \mathrm{HR}$ & $\$ 24,000$ \\
\hline 0 & MAN LIFT & $30 \$ / \mathrm{HR}$ & $\$ 18,000$ \\
\hline & PIPE & $10 \$ / F T A D$ & $\$ 60,000$ \\
\hline 0 & AIR LINE & $5 \$ / F T A D$ & $\$ 30,000$ \\
\hline 0 & HOSE & $4 \$ / F T A D$ & $\$ 24,000$ \\
\hline 0 & ELETRICS & & $\$ 30,000$ \\
\hline 0 & CABLES & $3 \$ / F T A D$ & $\$ 18,000$ \\
\hline 0 & FANS & $200 \$ /$ FAN $/ M$ & $\$ 9,000$ \\
\hline 0 & STOPFINGS & $3000 \$ / X$ CUT & $\$ 27,500$ \\
\hline 0 & MISC VENT & 10 STOPP & $\$ 2,750$ \\
\hline & ELEC POWER & 0.024 \$/KWH & $\$ 120,000$ \\
\hline & CRUSHING & $1.00 \$ / \mathrm{TON}$ & $\$ 392,000$ \\
\hline & DEWATERING & & $\$ 75,000$ \\
\hline & MN AIR HEAT & $2.00 \$ / M C F$ & $\$ 23,400$ \\
\hline & ORE PASSES & $240000 \$ \mathrm{EA}$ & $\$ 92,000$ \\
\hline & SHOTCRETE & $300.00 \$ / C Y$ & $\$ 320,000$ \\
\hline & OVERHEAD & & \\
\hline & 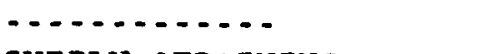 & & \\
\hline 0 & SUPPLY \&TRAINING & & $\$ 9,000$ \\
\hline 0 & COMMUNICATION & & $\$ 5,000$ \\
\hline 0 & TRAVEL & & $\$ 10,000$ \\
\hline 0 & RELOCATION EXP & & $\$ 2,000$ \\
\hline 0 & RECRUITING & & $\$ 5,000$ \\
\hline 0 & INSTRUMENTATION & & $\$ 3,500$ \\
\hline 0 & ROPE SOAP \& DOPE & & $\$ 10,000$ \\
\hline & TOTAL COST & T PER MONTH & $\$ 1,382,150$ \\
\hline & ESTIMATED & ANNUAL COST & $16,585,800$ \\
\hline
\end{tabular}


TABLE BJ ESTIMATED CAPITAL EQUIPMEMT ANO DEVELORMENT COSTS

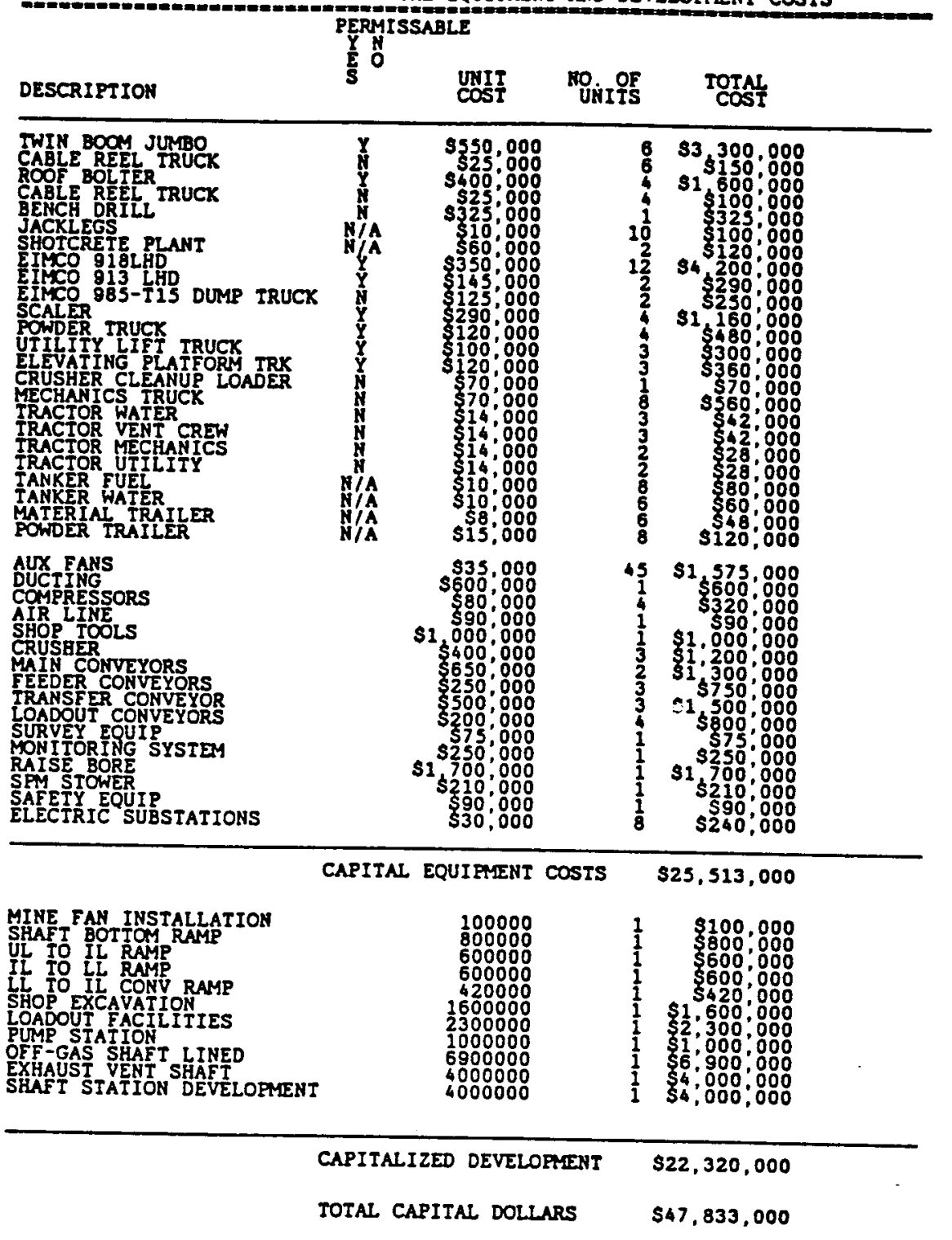


TABLE B4 - ESTIMATED CB DIRECT UNDERGROUND MINING COST

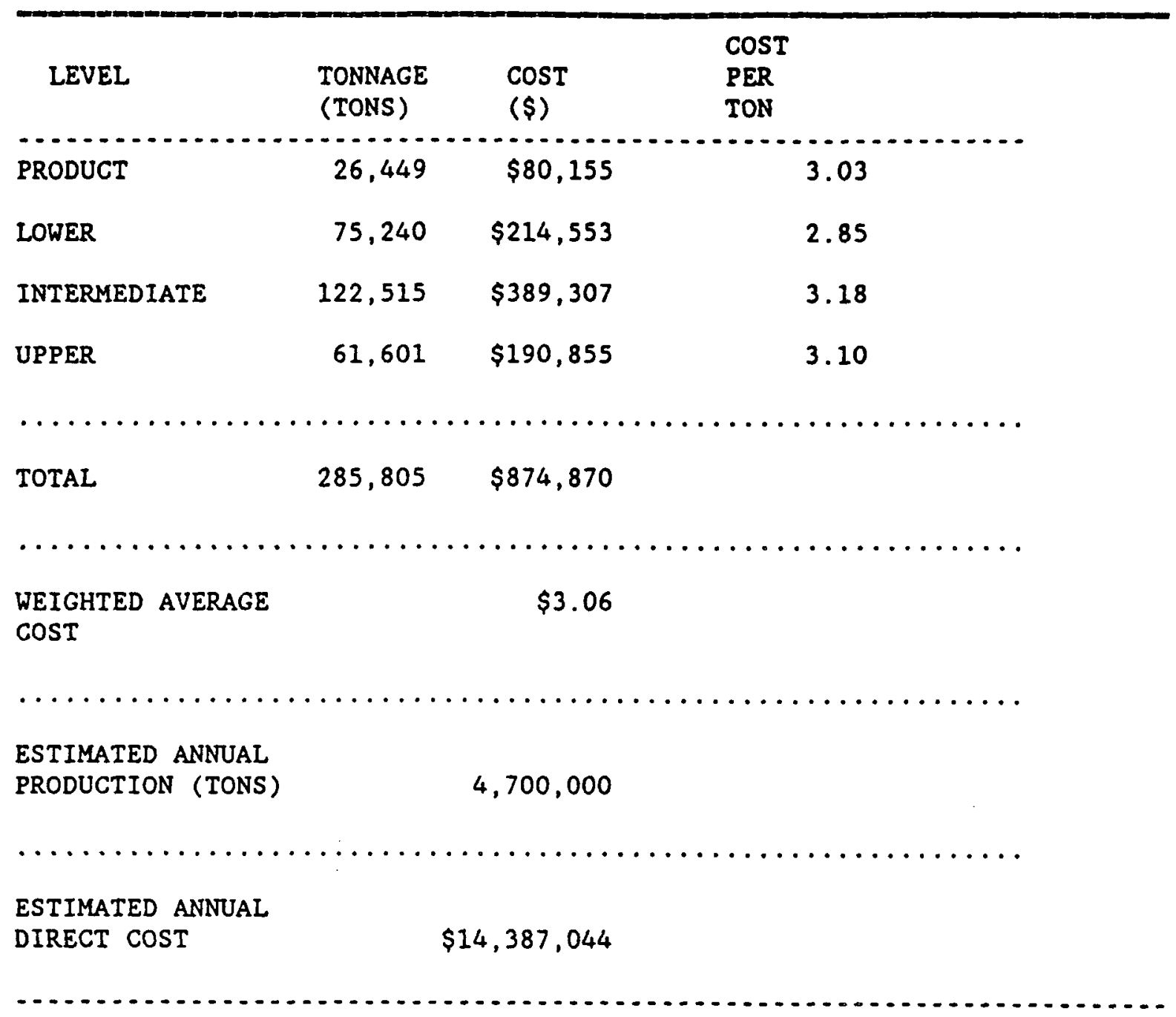


TABLE B4 - ESTIMATED CB DIRECT UNDERGROUND MINING COST

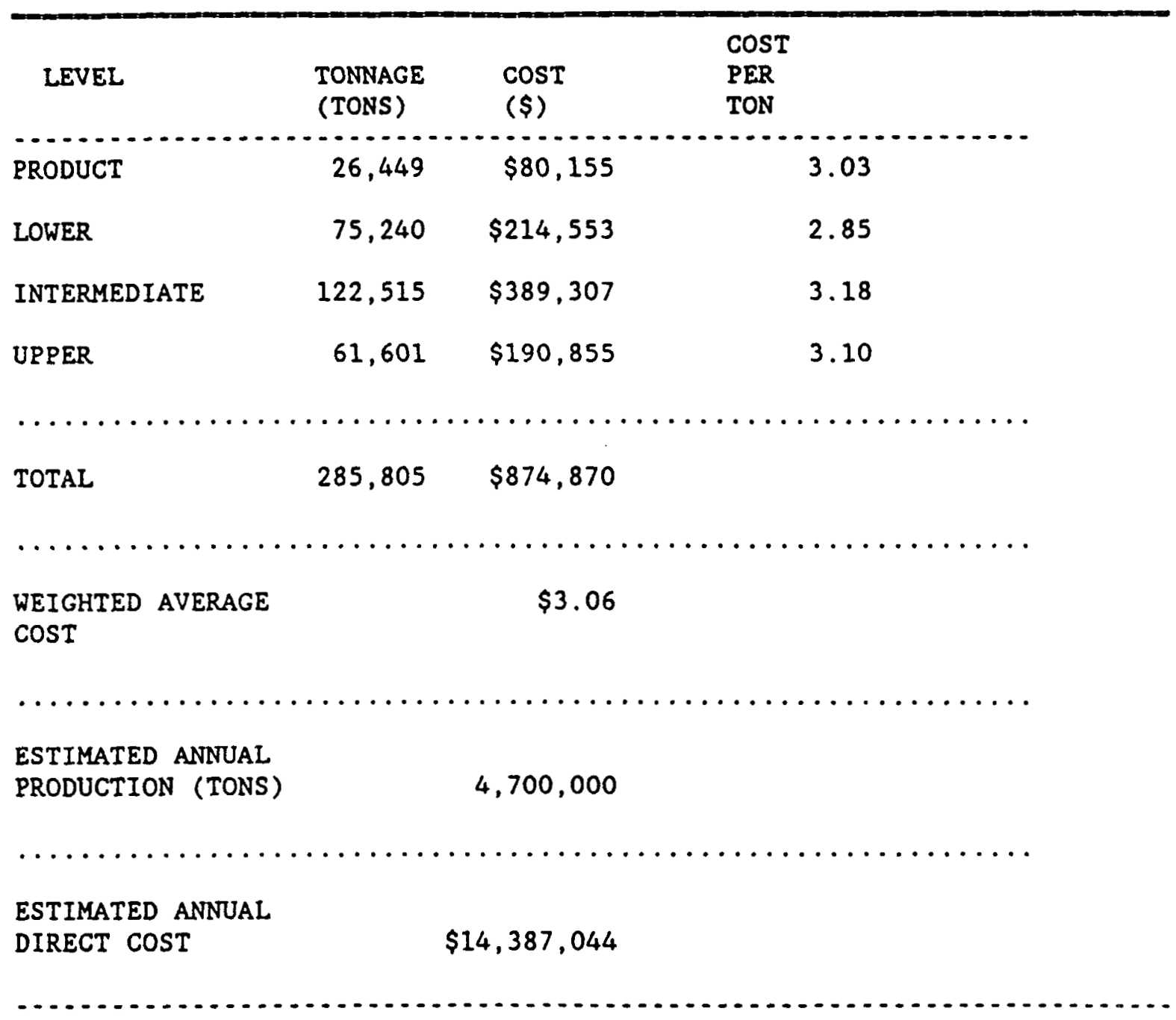

